UNIVERSIDADE DE SÃO PAULO

FACULDADE DE ECONOMIA, ADMINISTRAÇÃO E CONTABILIDADE

DEPARTAMENTO DE ECONOMIA

PROGRAMA DE PÓS-GRADUAÇÃO EM ECONOMIA

\title{
DINHEIRO INCONVERSÍVEL, DERIVATIVOS FINANCEIROS E CAPITAL FICTÍCIO: A MODERNA LÓGICA DAS FORMAS
}

Tomas Nielsen Rotta

Orientador: Prof. Dr. Leda Maria Paulani

SÃO PAULO

2008 
Profa. Dra. Suely Vilela

Reitora da Universidade de São Paulo

Prof. Dr. Carlos Roberto Azzoni

Diretor da Faculdade de Economia, Administração e Contabilidade

Prof. Dr. Joaquim José Martins Guilhoto

Chefe do Departamento de Economia

Prof. Dr. Dante Mendes Aldrighi

Coordenador do Programa de Pós-Graduação em Economia 


\title{
DINHEIRO INCONVERSÍVEL, DERIVATIVOS FINANCEIROS E CAPITAL FICTÍCIO: A MODERNA LÓGICA DAS FORMAS
}

\author{
Dissertação apresentada ao Departamento \\ de Economia da Faculdade de Economia, \\ Administração e Contabilidade da \\ Universidade de São Paulo como requisito \\ para a obtenção do título de Mestre em \\ Economia
}

Orientador: Prof. Dr. Leda Maria Paulani

\section{SÃO PAULO}


FICHA CATALOGRÁFICA

Elaborada pela Seção de Processamento Técnico do SBD/FEA/USP

Rotta, Tomas Nielsen

Dinheiro inconversível, derivativos financeiros e capital

fictício : a moderna lógica das formas / Tomas Nielsen Rotta.

-- São Paulo, 2008.

$204 \mathrm{p}$.

Dissertação (Mestrado) - Universidade de São Paulo, 2008

Bibliografia

1. Economia política 2. Economia marxista 3. Economia monetária I. Universidade de São Paulo. Faculdade de Economia, Administração e Contabilidade. II. Título.

$$
\text { CDD - } 330
$$




\section{Resumo}

Este trabalho investiga a adequação científica das teorias monetárias e financeiras marxistas em face à nova realidade do pós-1971, tendo como ponto de partida a introdução lógica da forma dinheiro inconversível. A primeira parte, composta pelos dois primeiros capítulos, discute as duas maiores heranças que Marx recebeu - Hegel e o pensamento monetário inglês do século XIX -, para aí evidenciarmos tanto suas potencialidades quanto suas inevitáveis limitações. Quando passamos à segunda parte, constituída pelos dois últimos capítulos, o foco recai sobre a tentativa de fazer as categorias marxistas se adequarem ao nosso hodierno sistema financeiro e monetário; com um ponto claro: mostrar a ligação necessária entre o dinheiro inconversível e a atual formação de capital fictício. Momento no qual os derivativos financeiros se revelarão objetos contraditórios e, mais do que instrumentos, produtores de suas próprias pressuposições - em especial, o risco abstrato. Dessa forma estaremos aptos a analisar em toda sua profundidade o ciclo do moderno capital fictício - da mercadoriacapital, do capital que retorno como capital ao seu predicado lógico inicial. O resultado deste movimento será o engendramento de um novo capital abstrato, para o qual os swaps são seu veículo.

Palavras-chave: Teoria Monetária, Teoria Financeira, Marx, Dinheiro, Capital, Capital Fictício, Derivativos.

\section{Abstract}

Departing from the logical introduction of the inconvertible money form this dissertation investigates the scientific adequateness of the monetary and financial Marxist theories to the new post-1971 reality. The first part, constituted by the first two chapters, discusses the two main heritages that Marx received - Hegel and the English monetary thought from the $19^{\text {th }}$ century - to then make evident both its potentialities and its inevitable limitations. Moreover, with the clear objective of disclosing the necessary connection between inconvertible money and the present formation of fictitious capital, the second part, composed by the last two chapters, will focus on the attempt to adequate Marxist categories to our hodiern financial and monetary system. Moment to which financial derivatives will reveal themselves as contradictory objects and, more than just hedge devices, as producers of their own presuppositions - in special, abstract risk. In this way, we will be capable to analyze in all its profoundness the circuit of the modern fictitious capital - capital-commodity, capital that returned as capital to its first

logical predicate. The outcome of this movement is the yield of an abstract capital, to which swaps are its vehicle.

Key-words: Monetary Theory, Financial Theory, Marx, Money, Capital, Fictitious Capital, Derivatives. 



\section{Agradecimentos}

Agradeço, em primeiro lugar, à minha família, especialmente a meus pais e a meus irmãos, que ao longo deste quarto de século deram apoio incondicional às minhas conquistas e aos meus caprichos. A eles por tudo.

Sou eternamente grato à Universidade de São Paulo e à FEA pelas condições que proporcionaram aos meus estudos e anseios. Menciono também os apoios financeiros que recebi como bolsista do CNPq, da FAPESP e da Red de MacroUniversidades (que me proporcionou um ótimo estágio de pesquisa na Universidade Nacional Autônoma do México, UNAM, sob a co-tutela do professor Alejandro Valle Baeza).

À Leda Paulani, que muito mais do que uma excelente orientadora foi uma pessoa que acreditou e apostou no meu potencial acadêmico. E este é o melhor sentimento que um orientando de mestrado pode ter.

Aos excelentes professores que tive nesta escola, e que faço questão de mencioná-los nominalmente: Eleutério Prado, Raul Cristóvão dos Santos, Jorge Soromenho, Gilberto Tadeu Lima e Leda Paulani. Adicionalmente ao professor Vladimir Safatle pelo exemplar curso de filosofia hegeliana (com um ano de duração) na FFLCH-USP, e ao professor Alfredo Saad-Filho, da University of London (SOAS), que fez comentários sobre uma versão prévia desta dissertação. Agradeço aos professores Raul Cristóvão e Jorge Grespan (FFLCH-USP) pelas sugestões acerca do meu projeto inicial, e aos professores João Machado Borges Neto (PUC-SP) e Raul Cristóvão como membros da minha banca de qualificação.

Aos funcionários da FEA, em especial aos da seção de alunos de pós-graduação (Valéria, Cida e Francisco), aos da coordenação da pós-graduação (Márcia Bento), aos da seção de alunos da graduação (Valdir, Wagner e Manoela), às secretárias da FIPE (Erminda e Sandra), às funcionárias da biblioteca e aos funcionários do xerox.

Agradeço também aos meus colegas de graduação e de pós-graduação, sem os quais eu teria sido uma pessoa completamente diferente, certamente bem mais incompleta. Em especial, menciono um colega meu, Leonardo Nunes, que sempre esteve ao meu lado e que muito me serviu como exemplo a ser seguido, seja por sua inteligência ou por seu carisma. Veremos o que o futuro nos tem a reservar. E para aqueles que nos consideram demasiado radicais, lhes respondo com Bertold Brecht: "Do rio que tudo arrasta se diz que é violento; mas ninguém diz violentas as margens que o comprimem". 

A diferença entre centro e periferia já está clara desde muito tempo:

"A fogueira é era mim, mas a fumaça era em você" (Depois da Derradeira, de Dominguinhos e Fausto Nilo, muito cantada por Luiz Gonzaga)

"O dólar é nosso, mas o problema é de vocês" (John Conally, ex-secretário do Tesouro dos EUA, citado em Eichengreen (2000)) 



\title{
Índice
}

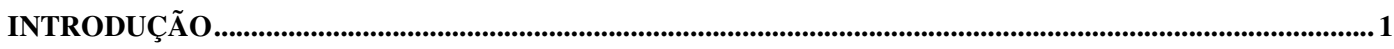

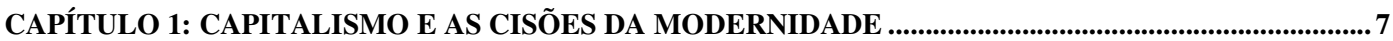

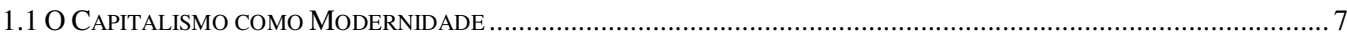

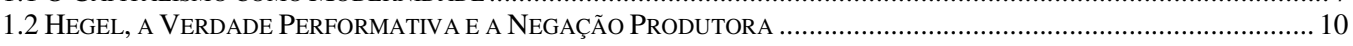

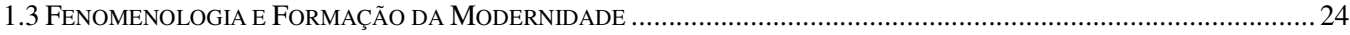

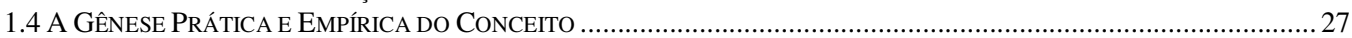

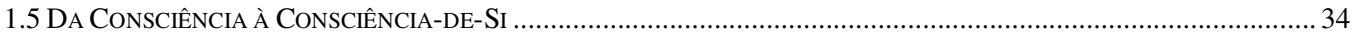 \\ CAPÍTULO 2: TEORIAS MONETÁRIAS NO SÉCULO XIX.........................................................................39

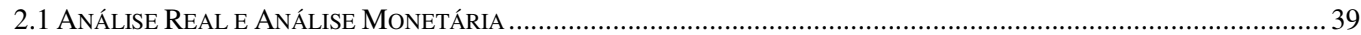

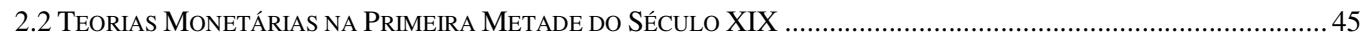 \\ 2.2.1 Hume, Ricardo e A Teoria Quantitativa da Moeda ……...................................................................... 45

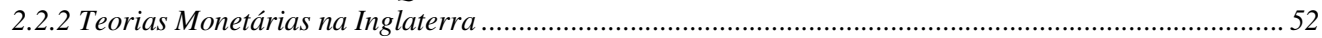

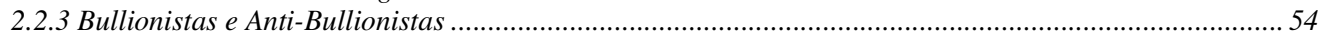

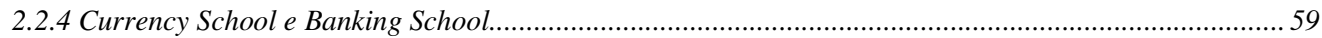

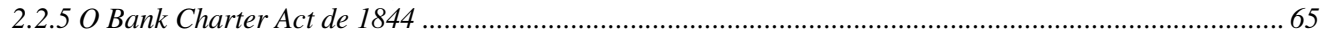 \\ 2.3 MARX E A HERANÇA DA BANKING SCHOOL: UMA CRÍTICA ........................................................................ 70 \\ 2.3.1 Entesouramento, Lei do Refluxo e Oferta Monetária ........................................................................................ 70 \\ 2.3.2 A Teoria Monetária de Marx Fragilizada Internamente ................................................................... 77 \\ 2.4 Teorias Monetárias A Partir da Segunda Metade do Século XIX …......................................................... 81
}

CAPÍTULO 3: A TEORIA MONETÁRIA DE MARX: SUA ATUALIDADE E SEUS LIMITES......................87

3.1 Nem ECONOMia REAL E NEM ECONOMIA MonetÁRIA ....................................................................................... 87

3.2 Dinheiro Enquanto Moeda e a Moeda Inconversível: Da Realidade Efetiva À Realidade....................8 88

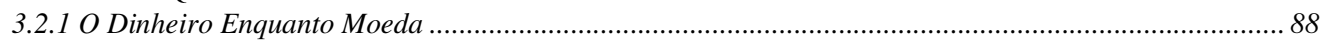

3.2.2 A Moeda Enquanto Medida dos Valores ……............................................................................... 92

3.2.3 A Moeda Enquanto Meio-de-Circulação ................................................................................................. 96

3.2.4 A Moeda Enquanto Moeda Inconversível: Sua Necessidade Lógica .................................................... 99

3.2.5 A Moeda Enquanto Moeda Inconversível: Auto-Referência, Convencionalismo e Fetichismo ............... 105

3.2.6 O Problema da Moeda Inconversível como Medida dos Valores ...................................................... 110

3.2.7 O Problema da Moeda Inconversível como Meio-de-Circulação: Do Símbolo ao Signo........................ 119

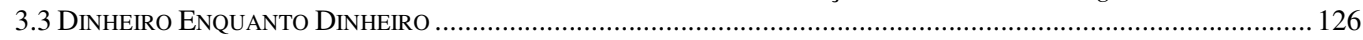

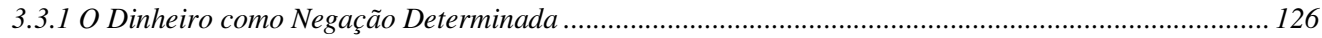

3.3.2 O Crédito como Capital Fictício Embrionário: O "Dinheiro Fictício".................................................. 129

3.3.3 O Dólar Inconversível Pós-1973 como Dinheiro Mundial ............................................................... 131

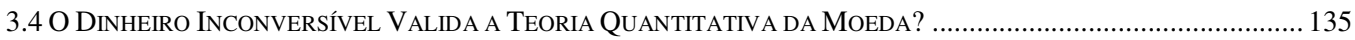

3.5 O DinHEIRO INCONVERSÍvEL E A TRANSFORMAÇÃo DOS VALORES EM PREÇOS ................................................ 141

3.5.1 O Problema Original e suas Pressuposições .................................................................................. 142

3.5.2 O Debate Moderno Acerca da Transformação: a NI, o SUT e a MELT ................................................. 145

CAPÍTULO 4: DO DINHEIRO INCONVERSÍVEL AO MODERNO CAPITAL FICTÍCIO ........................... 151

4.1 O CAPITAL FINANCEIRO OU O CAPITAL-PORTADOR-DE-JUROS ...................................................................... 151

4.2 O SiSTEMA FINANCEIRO COMO INTERMEDIÁRIO: UMA CRÍTICA DiALÉTICA ................................................... 156

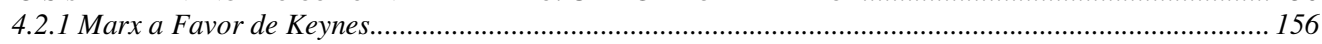

4.2.2 A Aparência Necessária do Sistema Financeiro................................................................................ 158

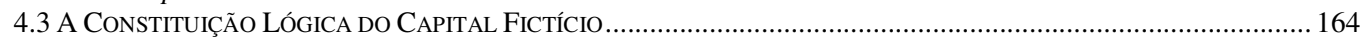

4.3.1 Do Valor ao Valor Fictício e Sua Inter-versão: o Valor Fictício como Vir-a-Ser-Valor ...................... 164

4.3.2 Capital Financeiro e Capital Monetário como Predicados do Capital Fictício...................................... 170

4.3.3 O Capital Fictício: A Mercadoria-Capital e o Seu Ciclo M-M'..................................................... 171

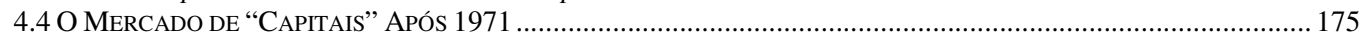

4.4.1 O Mercado de Capitais como Aparência ........................................................................................... 175

4.4.2 O Dinheiro Inconversível e o Capital Fictício Próprio a Ele …….................................................... 177

4.4.3 Dinheiro Inconversivel e Taxas Cambiais .................................................................................... 180

4.4.4 Dos Derivativos aos Derivativos Financeiros ................................................................................. 182

4.4.5 Derivativos Financeiros como Mercadoria e a Produção do Risco Abstrato ............................................. 186

4.4.6 Derivativos Financeiros como Capital Abstrato ou a Mercadoria como Capital Absoluto ................... 191

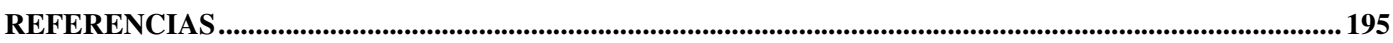





\section{Introdução}

A riqueza das sociedades onde rege a produção capitalista aparece como uma imensa acumulação de papéis, bônus, títulos e derivativos. Mais do que uma imensa coleção de mercadorias, nossa sociedade se mostra como imensa coleção de papéis: "tudo aparece aqui invertido, pois nesse mundo de papel o preço real e seus momentos reais nunca aparecem, mas apenas barras, dinheiro metálico, notas, letras de câmbio e papéis de crédito" (Marx 1984b, p.28). Vivemos, aliás, em uma época em que a universalidade do capital está fortemente consolidada, e a singularidade, como convém, tornou-se tanto mais insignificante; em que universalidade se aferra a toda a sua extensão e riqueza acumulada e as reivindica para si.

A palavra "capital" fez parte da terminologia financeira e jurídica antes mesmo que os economistas fizessem uso dela. Entre os juristas romanos e seus sucessores tal palavra denotava o "principal" de um empréstimo, em contraposição à parte devida aos juros e outras exigências paralelas. Os usos posteriores, em clara remissão a esta idéia, denotavam as somas de dinheiro ou seus equivalentes que eram subscritos para formar uma empresa ou uma sociedade de negócios. O conceito era, então, essencialmente monetário (Schumpeter 1955, p.323), representando dinheiro existente, direitos sobre dinheiro ou ativos cotados em dinheiro. Muita confusão teria sido poupada se os economistas tivessem se apegado à idéia monetária, ou financeira, de capital.

Diante das formas econômicas que hoje são postas a descoberto, a mente humana fica, no mínimo, inquieta, para não dizer desesperada. As novas práticas do mercado financeiro colocam, sem dúvida alguma, desafios renovados à Teoria Econômica e aos seus conceitos estabelecidos. Neste sentido, esta dissertação parte do entendimento de que o que julgamos ser a Teoria Econômica Marxista nos fornece o melhor referencial teórico para trabalharmos essas categorias do real. Ainda assim, é inegável que Marx esteja restrito objetivamente à época do capitalismo em que viveu - fato que nos serve como desafio imediato para pensarmos sua adequação às formas que hoje imperam.

O objeto de estudo deste trabalho é claro: a atual (pós-1971) dinâmica financeira do capitalismo. Donde perguntamos: é a teoria econômica marxista adequada a tal 
empreitada? Podem as categorias desenvolvidas por Marx dar conta dos sistemas monetário e financeiro que hoje temos?

Não obstante, nosso primeiro ponto sobre a financeirização exige uma leitura hegeliana do capitalismo. Se Hegel entende a modernidade como um momento lógico e histórico de uma cisão entre universal e particular, entre em-si e para-si e entre sujeito e objeto, Marx não fica aquém disto: para ele o capitalismo é também um momento lógico e histórico de cisões entre universal e particular, entre valor e valor-de-uso, entre trabalho abstrato e trabalho concreto e entre forma e substância. Seja como modernidade ou como capitalismo, é a abstração o poder hegemônico de nossos dias: "individuals are now ruled by abstractions, whereas earlier they depended more on one another" (Marx 1973, p.164). A mercadoria, primeiro predicado lógico do sujeito capital - sendo o dinheiro o segundo -, já incorpora ela mesma as cisões da modernidade. Cisões estas que se revelarão como fundamentais para compreendermos a autonomia das formas financeiras e fictícias do capital.

O conceito - em seu sentido hegeliano - não diz respeito somente a uma estrutura teórica e científica, mas sim às formas de vida e aos modos de interação social. O dinheiro enquanto objeto se tornou, após 1970, dinheiro sem lastro. As novas formas de relação que daí emergiram são evidentes por si só quando observamos a atual dinâmica das finanças mundiais e o seu comportamento aparentemente autonomizado em relação aos "fundamentos reais". Os conceitos de dinheiro, de capital monetário, de capital financeiro e de capital fictício devem, portanto, sofrer o impacto da experiência exatamente ali onde a plasticidade do objeto produziu novos regimes para a vida social.

Assim como ficará patente quando analisarmos a filosofia hegeliana, a lógica é, acima de tudo, uma relação social. Os problemas sócio-políticos são problemas lógicos, e os problemas lógicos devem ser problematizados como questões sociais. Todo problema social é ontológico. E, assim como estabelece Hegel, as relações cognitivas são subordinadas às relações sociais, relações estas de conflito, dessimetria e de luta. $\mathrm{O}$ próprio Hegel, antes de Marx, já mostrava a subordinação da cognição à prática social e a gênese empírica e prática dos conceitos. Desse modo, aqui trabalharemos com dois pontos centrais: (i) as contradições são reais, ou seja, o próprio objeto produz uma contradição para o pensar - a contradição vem do objeto, e não do pensamento; (ii) as 
relações cognitivas são relações derivadas das relações inter-subjetivas e institucionais. Este é o tema de nosso primeiro capítulo e a chave teórica para tematizarmos os conceitos monetários e financeiros em nosso século.

$\mathrm{Na}$ forma dinheiro conversível revelar-se-á a tensão existente dentro da unidade entre seu modo aparente de ser (sua função) e seu modo efetivo de ser (como metal). (Marx 1973, p.150). O que revela justamente a tensão entre particular (seu modo de ser específico) e universal (seu modo social, funcionante, de ser). É, portanto, um ser unitário cindido em contrários. Sua substância natural está em conflito contínuo com sua função. Assim entendido o problema, percebe-se que a forma dinheiro inconversível $^{1}$ é a forma que soluciona esse conflito entre matéria e função do dinheiro. A forma dinheiro sem lastro resolve tal contradição justamente por desprender-se de qualquer materialidade particular. E mais do que isso: na figura do dólar atual dissolvese a contradição entre particularidade e universalidade, como está presente nos escritos de Marx, para dar lugar a uma nova contradição em um patamar mais elevado, agora entre particularidade, como moeda de um país em específico, e universalidade, como moeda mundial. O padrão dólar puro resolve a contradição do dinheiro ao generalizá-la, ao torná-la, de fato, mundial ${ }^{2}$. Afinal "cada determinação se desdobra no interior dela mesma para produzir uma nova oposição" (Fausto 1997, p.46). O dólar é, assim, um singular, universal-concreto. Esta é sua nova essência. A hegemonia do dólar na hierarquia monetária internacional foi uma "solução" contraditória para o problema contraditório entre a moeda norte-americana e as moedas nacionais dos grandes países. Ademais, aparece o dólar inconversível como existência contingente quando em essência é existência necessária. Isto é, aparece como efetividade cuja necessidade não é absoluta, necessidade fortuita, externa, fruto de um capricho institucional norteamericano; mas que em sua essência nega tal aparência para se pôr como existência necessária, não apenas existente, mas existente necessariamente. E, como veremos, a

\footnotetext{
${ }^{1}$ Ao longo desta dissertação, usaremos as palavras "inconversível" e "sem lastro" como sinônimos para nos referirmos sempre à forma Dinheiro do padrão dólar-dólar que se iniciou com o Governo Nixon nos EUA na década de 1970. A propósito, a palavra "redemption" em inglês tem duplo significado: pode tanto significar "salvação" dos pecados cometidos, como também pode significar "conversão de papelmoeda em ouro". Desse modo, o dinheiro inconversível, "irredeemable money", é dinheiro que não pode mais ser salvo, é dinheiro sem remissão. Se Jesus Cristo se sacrificou para livrar os pecados da humanidade, o dinheiro sem lastro lhe escapou por entre os dedos.

${ }^{2} \mathrm{E}$ com isso torna o capitalismo inexoravelmente mais atrelado do que antes às questões relativas ao poder geopolítico.
} 
universalidade enquanto dinheiro nunca é estável, daí sua inquietude de forma, que a faz mover-se como conceito.

A primeira pergunta crucial que queremos responder é, antes de tudo, se o conceito marxista de dinheiro consegue dar conta da forma dinheiro inconversível do pós-1971. Ou seja: poderia o padrão dólar puro ser contemplado de alguma forma na apresentação lógica das categorias monetárias em Marx? Após a leitura dos textos centrais, nossa resposta não podia ser outra: sim e não. Sim, porque o dinheiro para Marx é essencialmente forma pura. Não, porque de fato o dinheiro inconversível não está posto no discurso marxista. O capítulo 3 trata disto: de mostrar a necessidade lógica do dinheiro inconversível - cuja prova segue um argumento negativo - e de mostrar quais são novos os problemas teóricos que esta forma nos traz - que, aliás, são inúmeros e que vão desde sua determinação ainda indefinida como medida dos valores, passando por seu convencionalismo, até sua também indefinida proximidade com a Teoria Quantitativa da Moeda. Veremos como desde o início a TQM já quisera pôr a descoberto a essência puramente formal do dinheiro, embora o padrão-ouro e a oferta monetária endógena a impedissem de efetivamente realizar isso. O pós-1971 viria, não obstante, a dar um momento de verdade à TQM.

Quanto ao dinheiro como dinheiro de fato, Marx se revelará tributário da Banking School e da tradição anti-quantitativista inglesa. Essa característica, que será o tema do capítulo 2, representa uma grande riqueza e ao mesmo tempo um grande percalço de sua teoria monetária e creditícia. Seu posicionamento em relação aos debates acerca do padrão monetário na Inglaterra do século XIX o fez progredir para além das teorias de Stuart, Tooke e Fullarton, as quais esposou decididamente - ainda que de maneira crítica -, mas concomitantemente o fez rejeitar em demasiado as doutrinas opostas da Currency School. Suas teses sobre a circulação de dinheiro, que tomou de Stuart, em que o tesouro exerce papel crucial, e suas teses da circulação do crédito, em que a Lei do Refluxo de Fullarton lhe é essencial, são sua principal fraqueza quando cotejadas com a hodierna fase do capitalismo sob a égide do dinheiro inconversível e do capital fictício. Em particular, mostraremos que há uma inconsistência lógica entre sua adesão à Lei do Refluxo e sua análise mesma da formação de capital fictício - como já advertia, a propósito, Thornton no século XIX. 
Para o século XX, a dialética e a teoria de Marx serão também cruciais para mostrarmos que a divisão entre as teorias do sistema financeiro como intermediário e a teoria do dinheiro endógeno é justamente a divisão que Marx opera entre dinheiro enquanto moeda e dinheiro enquanto dinheiro: dinheiro enquanto moeda como aparência da circulação e dinheiro enquanto dinheiro como sua essência. Advogamos, assim sendo, que a essência e a aparência do sistema financeiro decorrem propriamente das determinações da forma dinheiro: o que é um fim se apresenta como um meio. Isto é, a relação essência/aparência do sistema financeiro duplica a relação essência/aparência da forma dinheiro. Essência (dinheiro como fim e o sistema financeiro como nãointermediário) e aparência (dinheiro como meio e sistema financeiro como intermediário) se negam e se determinam em uma relação contraditória. Se a aparência do sistema financeiro coube às teorias do sistema financeiro como simples intermediário e se a essência coube às teorias da oferta endógena de crédito, caberia então à teoria marxista a articulação do todo e a posição de ambos esses momentos como necessidades lógicas de uma realidade contraditória. Wicksell, neste caso, nos servirá de exemplo de como algo da essência já se faz presente na aparência.

Não obstante, se nossa resposta ao questionamento inicial - sobre se o conceito de dinheiro de Marx se adéqua ao objeto dinheiro inconversível que hoje temos - é parcialmente negativa, seria uma decorrência natural que Marx tampouco tenha incluído em seu raciocínio os impactos lógicos da forma dinheiro inconversível sobre as formas mais desenvolvidas do capital, quais sejam: capital financeiro e capital fictício. Nossa segunda tarefa central é, pois, mostrar que de fato Marx restringiu suas análises financeiras a um mundo dominado pelo padrão-ouro. Daí partimos para a nossa idéia de que a necessária ligação lógica entre o dinheiro inconversível e as modernas formas capital financeiro e capital fictício se faz através dos derivativos financeiros, que trataremos adequadamente como mercadoria sui generis, ou melhor, como mercadoriacapital, capital que se fez ele mesmo mercadoria ${ }^{3}$, sendo a forma mercadoria o

\footnotetext{
${ }^{3}$ Nesta dissertação, em que a linguagem tem foro privilegiado, devemos deixar claro para o leitor que o lugar das palavras não é fortuito. Ao longo das páginas que seguem encontrar-se-ão conceitos cujos sentidos não pode passar desapercebidos: capital-dinheiro $=$ capital que se fez dinheiro $=$ capital monetário $=$ momento do capital industrial capital-mercadoria $=$ capital que se fez mercadoria $=$ momento do capital industrial dinheiro-mercadoria $=$ dinheiro enquanto uma mercadoria particular (como o ouro) mercadoria-dinheiro $=$ dinheiro que se fez mercadoria $=$ capital financeiro mercadoria-capital = capital que se fez mercadoria e que se mantém como capital = capital fictício
} 
predicado que agora encarna algo do movimento do infinito hegeliano, tornando-se assim um predicado mais próximo do seu verdadeiro sujeito.

O ponto é que a posição do dinheiro inconversível ensejou a formação de um capital fictício próprio a ele, para o qual os derivativos financeiros têm papel central. Os quais, ao resolverem privadamente o problema de como investir em um ambiente em que o dinheiro mundial é uma pura forma, servem justamente de "instrumentos" que preenchem o vazio deixado pelo fim das regulações estatais pré-Nixon. Derivativos estes que serão conceituados como objetos contraditórios, pois aparecem como "instrumentos" (de gerenciamento de riscos), mas que em sua essência negam-se como meio para efetivamente se colocarem como produtores de um risco abstrato, a nova medida por excelência da mercadoria-capital, do capital que se fez mercadoria, do capital que se medeia consigo mesmo por meio de um outro que ele mesmo produz e que mantém como seu momento. Os derivativos são, desse modo, mercadorias peculiares, pois é o sujeito capital que aparece como uma coisa que tem um preço, que ganha status quase de movimento infinito e cuja finalidade lhe é interior em seu circuito característico: M-M', o qual internaliza suas pressuposições, isto é, produz sua próprias pré-condições. O resultado deste movimento será a formação do capital abstrato, para o qual os swaps serão seu veículo por excelência. 


\title{
Capítulo 1
}

\section{Capitalismo e as Cisões da Modernidade}

\author{
"I was searching for the Truth and in the \\ end I found Money" (George Soros - \\ resposta dada ao apresentador do \\ programa Roda Viva em 18/06/2007 ao ser \\ questionado sobre qual o motivo de \\ acumular tanta riqueza pessoal)
}

Nosso primeiro capítulo parte da idéia de que Marx manteve o conceito hegeliano de modernidade como um momento lógico e histórico de cisões, a partir das quais a consciência vê seus alicerces mais sólidos se tornarem fluídos. Consciência esta que ao inquietar-se com os problemas práticos advindos das relações cognitiva entre sujeito e objeto passa a questionar suas próprias estruturas do saber. A importância desta análise é dupla, já que servirá de ponto de partida para entendermos que a autonomização das formas mais desenvolvidas do capital - que serão objeto de investigação dos capítulos subseqüentes - decorrem justamente desta cisão original própria à modernidade e, em segundo lugar, pois nos servirá para evidenciar que a linguagem não-dialética, uma que não respeita a realidade perpassada pela negatividade, tem suas bases fragilizadas a partir de problema de ordem prática.

\subsection{O Capitalismo como Modernidade}

A mercadoria é imediatamente um objeto externo que satisfaz necessidades humanas e pode, como coisa útil, ser apreendida segundo um duplo caráter. E, se com Hegel (2002, $\S 405$, p.282-284) o conceito de obra constitui-se como espaço de tensão entre as expectativas da individualidade e o fato dela circular socialmente - ou seja, como campo de conflito entre algo que foi produzido individualmente mas que deve ser aceito socialmente -, o conceito marxista de mercadoria o faz com suas duas determinações, 
valor-de-uso e valor. A mercadoria é, assim, um campo de tensão social, ao mesmo tempo em que se apresenta como objeto externo.

Tanto em Marx quanto em Hegel o sujeito se perde e se re-encontra naquilo que antes tomava por mais exterior. $\mathrm{O}$ objeto que parecia ser independente e autônomo revela-se como de fato constituinte do próprio sujeito. Se a mercadoria aparecia originalmente à consciência como puro particular e como produto de caprichos e de desejos específicos, mostra-se em um segundo momento como já portadora da universalidade social. Seu conceito não-solipsístico, como relação social, mostra-a como momento de um universal. A consciência, ao descobrir o valor como substância, descobre que o que lhe parecia autônomo lhe é, de fato, interior. O economista, ao querer apreender o produto do trabalho como simples e imediato objeto, se vê necessitado de explicar as trocas. Para explicar as trocas, tem de recorrer a um mecanismo de reprodução social e de reposição das condições universais. O que se julgava ser o mais imediato se torna o mais mediatizado. $O$ que se julgava ser o mais simples revela-se como o mais complexo. Neste sentido, a dificuldade em apreendermos teoricamente a forma capital é o fato de que este, apesar de ser uma relação social, aparece como um objeto externo e autônomo. Portanto, a questão científica reside em apreender como conceito relacional aquilo que nos aparece como objeto solipsístico.

O indivíduo forma a sua individualidade ao ser possuidor de objetos, ou seja, os objetos são constituintes dos indivíduos, e não meros objetos externos ou solipsístico: “[...] the individual in one of his aspects objectifies [vergegenständlicht] himself in the thing, so that his possession of the thing appears at the same time as a certain development of his individuality" (Marx 1973, p.221-222). Sujeito e objeto constituem um processo performativo, para o qual a verdade é produzida e para qual o conhecimento se descaracteriza enquanto instrumento e meio.

A forma mercadoria adquirida pelos produtos do trabalho consubstancia sua cisão interna entre valor-de-uso e valor e a dissociação entre valor-de-uso e valor-de-troca. A mercadoria só é enquanto objeto duplo, com dupla forma, concomitantemente útil (sua realidade natural) e portador de valor (sua realidade social): "the natural distinctness of commodities must come into contradiction with their economic equivalence" (Marx 1973, p.141). Sua existência é, portanto, dupla, como coisa natural 
e como coisa econômica. O que também já é sua existência dupla como particular e como universal: "as a value, the commodity is general; as a real commodity it is particular" (Marx 1973, p.141). Desta cisão Marx mostra que o capitalismo implica uma forma de riqueza que nega e conserva aquilo que a sustenta. $\mathrm{O}$ valor-de-uso é a matéria de uma forma que a nega, sendo que a forma, isto é, o valor, se torna também conteúdo, finalidade do processo, suprimindo o verdadeiro conteúdo, a substância primeira, que é a materialidade.

Atentemos para isso. Se para Hegel a Modernidade é um momento de cisão entre o universal e os particulares, entre sujeito e objeto e entre o em-si e o para-si, Marx também mantém o capitalismo como momento de uma cisão entre o universal (o valor) e os particulares (os valores-de-uso). Sendo esta cisão a que justamente permite a autonomização do universal frente aos seus particulares - ainda que o segundo seja a forma de manifestação por excelência do primeiro. Em outras palavras, o capitalismo é um momento lógico em que o universal e o seu modo de manifestação, os particulares, estão separados; e é desta separação (que primeiramente é entre valor e valor-de-uso) que se dá a autonomização do universal frente aos particulares. Só há autonomização se há já originalmente uma separação. Como veremos, a autonomia e a automaticidade do capital, do capital financeiro e do capital fictício decorrem logicamente da cisão entre universal e particular como aspecto constituinte da mercadoria. Não há nada no capitalismo que já não esteja embrionariamente na forma mercadoria. A propósito, parece que Marx também se aproxima de Hegel em outro sentido, pois parece haver uma certa influência das noções hegelianas de obra, coisa-mesma (a verdadeira obra) e o espírito (a verdadeira coisa-mesma) sobre, respectivamente, a mercadoria, o dinheiro (a verdadeira mercadoria) e o capital (o verdadeiro dinheiro). Portanto, para Marx a verdade da mercadoria é o dinheiro, e a verdade do dinheiro é o capital; enquanto que em Hegel a verdade da obra é a coisa-mesma, e a verdade da coisa-mesma é o espírito. 


\subsection{Hegel, a Verdade Performativa e a Negação Produtora}

De imediato, vemos que Hegel nos deixou duas grandes obras: a Fenomenologia do Espírito e a Enciclopédia. Entendemos que ambas constituem dois sistemas distintos de exposição - o Fenomenológico e o Enciclopédico - do mesmo objeto e com uma causação mútua entre ambos. São dois regimes de discursividade. Isto é, são autônomos e ao mesmo tempo relacionados entre si. A Lógica, seja ela a Ciência da Lógica ou a Lógica da Enciclopédia, mostra a nova gramática filosófica que resultou como saldo da Fenomenologia do Espírito (daqui por diante FE), cujo objetivo é expor o que estava pressuposto. É, por assim dizer, um espaço de posição das categorias para compreender o presente. A FE, por seu turno, é um espaço de formação [Bildung $]^{4}$, incusive formação mesma da verdade: "a verdade não é uma questão de descrição, mas de produção" (Safatle 2006, p.118).

Na Fenomenologia tem-se um movimento da experiência da consciência através de seus fracassos ao querer implementar seus próprios conceitos. Movimento este que é contínuo e reconstituível em sua integralidade e para o qual as figuras da consciência e da consciência-de-si descobrem e produzem suas estruturas do saber. Se é a figura da razão que compreende que há contextos sociais para se efetivar, é a figura do espírito a que buscará justamente a gênese deste contexto. Espírito este que não é a consciênciade-si absolutizada, mas sim um conceito que diz respeito a um espaço social compartilhado, não-metafísico, a uma práxis social, a um horizonte comum de significação que guia as ações individuais: "Spirit therefore denotes for Hegel not a metaphysical entity but a fundamental relation among persons that mediates their selfconsciousness, a way in which people reflect on what they have come to take as authoritative for themselves" (Pinkard 1996, p.9). Marx claramente bebeu destas águas e dela tirou seu conceito de capital, ainda que movimento automático, não-consciente e, portanto, fetichizado.

É um movimento único de um processo performativo e completo em que a consciência percebe que o que tomava por racional tem uma gênese social. Em poucas palavras, a Fenomenologia é um espaço de formação tanto do sujeito quanto do objeto, e

\footnotetext{
${ }^{4}$ O termo alemão Bildung dá conta de vários significados: educação, formação, desenvolvimento,
} aprendizagem e criação; todos eles próprios à apresentação fenomenológica. 
preâmbulo para a Ciência da Lógica. Esta última, por sua vez, não tem uma perspectiva de formação, pois é, ao contrário, como se os conceitos, ao mostrarem suas necessidades internas, estivessem falando diretamente. A FE é condição para se ler a Lógica, para que se possa abordar a verdade sob a perspectiva da ordem das razões e dos conceitos. Esquematicamente, entendemos a relação entre estas duas perspectivas como expresso na figura que segue:

Figura 1.1: Relação entre as Discursividades da F.E. e da Ciência da Lógica

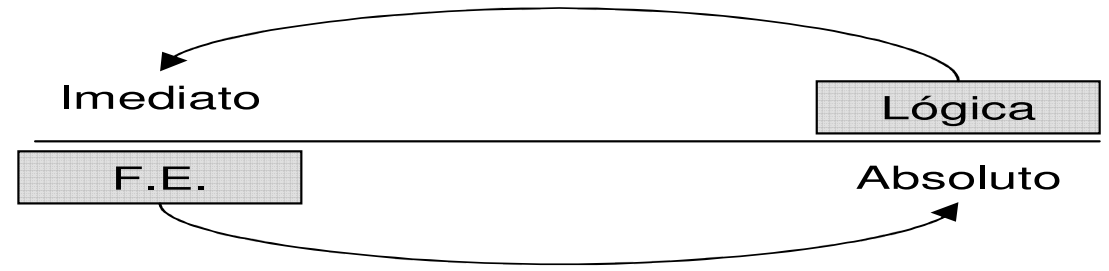

Se a FE é o ponto de vista da consciência, a Lógica é o da objetividade do saber. Neste sentido, obras como a Lógica e a Filosofia do Direito, se lidas por si só, parecem ser totalizantes, mas de fato somente podem ser devidamente compreendidas em função da perspectiva formadora da $\mathrm{FE}^{5}$.

O saber é um processo performativo, que cria, produz seus próprios objetos. O saber produz objetos. O pensar é um modo de posição do ser: "o conceito hegeliano ... é um operador performativo já que, em última instância e de uma maneira muito peculiar, ele produz a realidade à qual se refere. Em Hegel, há uma performatividade do conceito ligada ao caráter anti-representativo da dialética" (Safatle 2006, p.117). O mercado de derivativos aqui nos cai como uma luva: "derivative-pricing models appear successful not because they uncover pre-existing price patterns, but because the financial markets have changed in ways that make their assumptions more accurate" (LiPuma e Lee 2005, p.415). Isto é, a verdade não é algo que se descobre, mas sim é produzida pelo próprio saber. Nas palavras do próprio Hegel: "In the full truth of that liberation is given the

\footnotetext{
${ }^{5} \mathrm{Na} F E$ cada momento, que fornece uma figura e um conteúdo para a consciência, é a retomada do mesmo processo em um nível superior, onde o Absoluto é a retomada do processo histórico e lógico por completo. Os movimentos são circulares e todas as seções são diferentes, apesar de serem as mesmas, onde a mesma problemática é vista de vários ângulos. A questão é que na passagem de um nível ao outro há uma perda que produz uma instabilidade para a consciência. E, mais do que isso, os estágios deste processo, se forem hispotasiados, se invertem nos seus contrários.
} 
identification of the three stages - finding a world presupposed before us, generating a world as our own creation, and gaining freedom from it and in it. To the infinite form of this truth the show purifies itself till it becomes a consciousness of it" (Hegel 1830, $\S 386$ - ênfase nossa). Citação esta da Enciclopédia de 1830. Na versão anterior de 1817 a mesma citação encontra-se ligeiramente alterada em outro parágrafo: "The different steps in the activity of the spirit are steps towards its liberation, and in the absolute truth of this liberation these three steps are one and the same: finding a world presupposed, the generation of the world as a world posited by the spirit, and gaining freedom from the world" (Hegel 1817, §305 - ênfase nossa).

O nascimento da noção moderna de sujeito, que ocorrera com Descartes, ao procurar um fundamento para toda e qualquer dúvida e a base para o pensar impessoal, assentava-se no pensamento representativo. Para Descartes, pensar é pôr diante de si o objeto da representação. O sujeito (cogito) é o fundamento da existência e o indexador de um lugar vazio. Contudo, diz Hegel, há na filosofia cartesiana uma cisão entre o emsi e o objeto da experiência. O sistema filosófico hegeliano é justamente aquele que vai suspender estas antíteses rígidas criadas pelo pensamento representativo, que opera com identidades fixas, ao afirmar que a dúvida metódica não vai além do que deveria, isto é, pára no meio do caminho.

A lógica especulativa, como dimensão ontológica, vai problematizar as bases tomadas como sólidas da lógica formal. A FE é, assim, a passagem da negação das determinações à negação ontológica, a qual exigirá a tematização dos modos de fala e de escrita. Ou seja, aí está presente a idéia de que os problemas filosóficos são concomitantemente problemas gramaticais e que, portanto, a crítica à filosofia se faz necessariamente aliada à crítica da gramática. Afirmamos isto porque, com Hegel, fica evidente que a gramática determina os modos gerais de inferência, regras e processos (Safatle 2006). A linguagem, este aparecer do desaparecer, é toda a realidade; ou seja, não há nada externo a ela. O que tampouco é estranho a Marx, o qual, ao se contrapor ao método da Economia Política Clássica, disse que lhes faltava o método e a linguagem adequados. Afinal à Economia faltava adequar sua linguagem à linguagem dos objetos que investiga: a "linguagem peculiar, a das mercadorias" (Marx 2002, p.74) e um "método que decorre da natureza do fenômeno" (Marx 2002, p.203) e que a ele não é imposto externamente. O discurso, com dimensão e gênese empírica, deve se 
adequar ao seu objeto, à Coisa-mesma [Sache Selbst]: “A diferenciação das mercadorias em mercadorias e dinheiro não faz cessar essas contradições, mas gera a forma dentro da qual elas podem ser mover. Este é, afinal de contas, o método de solucionar contradições reais" (Marx 2002, p.131). É neste sentido que asseveramos: o problema da linguagem é um problema social ${ }^{6}$ e deve a Ciência, assim como a Economia, passar por uma reformulação lógica e gramatical para dar conta de objetos contraditórios e da negação em si (Lebrun 2006) ${ }^{7}$. A sintaxe deve admitir as contradições do real. A dialética, e deste ponto comungam Marx e Hegel, quer organizar a realidade perpassada pelo negativo e, para tal, a gramática deve dar conta desta dinâmica: "desde Hegel, a dialética funda-se no reconhecimento da negação ontológica, negação em si que aparece como modo de presença do objeto" (Safatle 2006, p.139).

Ao longo do plano hegeliano, fica claro que a propedêutica, este corpo de ensinamentos introdutórios ou básicos de uma disciplina científica, é inadequado ao fazer filosófico. A introdução deve fazer parte do sistema: o método não é externo ao objeto e o saber tampouco é uma descrição sobre algo independente deste saber: "O método é ... não uma forma exterior, mas a alma e o conceito do conteúdo" (Hegel 2002, §243, p.370). A ciência é, pois, a apresentação do seu conceito ${ }^{8}$.

Com Hegel, o idealismo não é idealismo subjetivo, no qual as coisas são somente frutos da nossa consciência. O idealismo de Hegel é um idealismo objetivo, que em muito se aproxima do materialismo de Marx: "a dialética, e também a de Marx, dá um lugar ao idealismo objetivo (os objetos do mundo têm a textura dos conceitos) e ao idealismo subjetivo (o pensamento põe determinações)" (Fausto 1989b, p.157) ${ }^{9}$. Para Kant e para

\footnotetext{
6 “[...] em Hegel, a exploração de problemas lingüísticos ... exige que eles sejam resolvidos através de uma recuperação do campo da ontologia" (Safatle 2006, p.110).

${ }^{7}$ Lebrun (2006) quer mostrar que Hegel reconstrói a noção de ontologia para dar dignidade de ser ao negativo, isto é, de tratar ontologicamente o negativo como negativo em-si.

${ }^{8}$ Desde o início deixemos claro que os descompassos lógicos se dão entre o objeto e o seu conceito, e não entre ele e um conceito que lhe é externo. Sobre o dinheiro dizia Marx: "Só no mercado mundial ... sua maneira de existir torna-se adequada a seu conceito" (2002, p.169). Que claramente assimilou o noção de verdade de Hegel como adequação entre objeto e o seu próprio e interno conceito

9 Ainda assim, diz Marx em diversos textos: "Meu método dialético, por seu fundamento, difere do método hegeliano, sendo a ele inteiramente oposto. Para Hegel, o processo do pensamento - que ele transforma em sujeito autônomo sob o nome de idéia - é o criador do real, e o real é apenas sua manifestação externa. Para mim, ao contrário, o ideal não é mais do que o material transposto para a cabeça do ser humano e por ela interpretado" (Marx 2002, p.28). "The abstraction, or idea, however, is nothing more than the theoretical expression of those material relations which are their lord and master" (Marx 1973, p.161). "[...] ficará espelhada, no plano ideal, a vida da realidade pesquisada, o que pode dar a impressão de uma construção a priori” (Marx 2002, p.28). "Em Hegel, a dialética está de cabeça para
} 
o entendimento, diz Fausto (idem), ao sujeito cabem as determinações e ao objeto cabe a posição. E nada mais. Um abismo intransponível separa, portanto, sujeito e objeto. Em Hegel, ao sujeito e ao objeto cabem tanto determinações quanto posições. Isto é, para o hegelianismo, o pensar põe (idealismo objetivo), mas há também determinações do próprio objeto. Para sujeito e predicado a posição é determinação, onde o não-posto mas determinado diferencia-se do posto e determinado. Enquanto o conceito não for posto, ele permanece como uma determinação subjetiva. O exemplo de Robinson Crusoé aqui cai como uma luva, pois aí o valor tem todas as suas determinações, ainda que lhe falte a determinação posição. Não obstante, o idealismo de Hegel também é objetivo, para o qual a textura do sujeito e do objeto tem a forma do conceito, este universal-concreto, este conjunto de determinações que são postas no sujeito e no objeto. Os domínios da apreensão têm caráter constitutivo. Na figura abaixo resumimos esquematicamente o que nos é apresentado em Fausto (1987b, p.178-179) sobre posição e pressuposição distinção essencial para nossa discussão sobre o dinheiro inconversível:

Figura 1.2: Campo Dialético de Significações

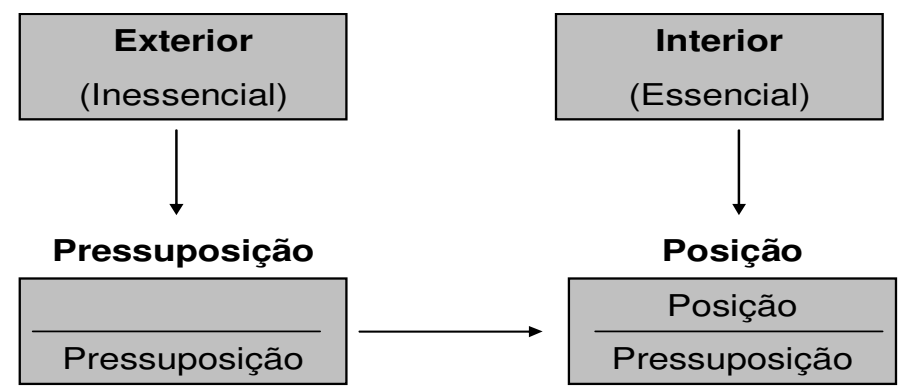

O campo exterior das significações condiz à pressuposição como não-posição, ao simplesmente pressuposto, à pura determinação, à determinação pressuposta, ao exterior ao sistema. Aqui a não-posição significa determinação insuficiente da posição, onde falta a determinação-posição. Por outro lado, o campo interior diz respeito à pressuposição posta mas suprimida, negada; mas uma negação interna ao sistema, pois a

baixo. É necessário pô-la de cabeça para cima, a fim descobrir a substância racional dentro do invólucro místico" (Marx 2002, p.29). Nos Grundrisse, ao apresentar certos desenvolvimentos lógicos da forma dinheiro, ainda em caráter de esboço, escreve Marx para si mesmo como um lembrete: "It will be necessary later, before this question is dropped, to correct the idealist manner of the presentation, which makes it seem as if it were merely a matter of conceptual determinations and of the dialectic of these concepts" (Marx 1973, p.151). 
pressuposição é aí momento essencial. Neste caso, no qual existe determinação-posição, a não-posição é determinação que foi além da posição (é determinação excessiva).

Hegel busca uma perspectiva imanente da experiência fenomenológica nas tensões internas das figuras e nas contradições entre o conceito e o efetivo, entre o saber e o objeto. Mas, entre o conceito e sua realização há uma inadequação, pois "a Coisa mesma não se esgota em seu fim, mas em sua atualização; nem o resultado é o todo efetivo, mas sim o resultado junto com o seu vir-a-ser" (Hegel 2002, §3, p.26-27 ênfase nossa). Na passagem entre os momentos da razão há uma perda, donde decorre a inadequação; a tarefa da consciência é justamente resgatar essas perdas para suprir as novas inadequações. A consciência chega ao saber pela superação das ilusões e dos erros acumulados.

A experiência fenomenológica aponta para a adequação entre conceito e objeto. Não obstante, ressaltemos: não há conceito de objetos particulares, mas de estados de coisas.

$O$ conceito concerne a uma estrutura de relações. A rede de relações é o verdadeiro objeto da experiência. $O$ que concerne aos objetos em particular é a representação. A lógica da representação é o discurso da distância e das cisões. A representação, lógica da cisão entre o em-si e o discurso/linguagem, pressupõe mais do que diz com seu discurso externalista:

“[...] o movimento dialético é impulsionado ... pelo reconhecimento da inadequação reiterada entre conceito e objeto da experiência, entre expectativas organizadoras do conceito e resistência do objeto. Há uma relação de negação entre conceito e objeto. Por outro lado, sabemos que 'conceito', em Hegel, não é um operador que se determina a partir da relação biunívoca com um objeto isolado, mas é a formalização de estruturas de relações entre objetos. Por isto, em Hegel, não podemos falar, em última instância, em conceito de objeto, mas em conceito de estados de coisas. [...] a 'correspondência' entre conceito e objeto só se dá quando o mesmo regime de negação que determina a confrontação entre conceito e objeto aparecer como processo estruturador de relações internas ao conceito" (Safatle 2006, p.116 - ênfases nossas) 
A chave da questão do conceituar é o respeito à indeterminação. $O$ conceito deve respeitar o movimento e a plasticidade dos objetos, ele deve respeitá-los como objetos que não podem ser totalmente determinados, exatamente por também serem permeados por um momento fundamental de indeterminação. $O$ conceito, para se tornar adequado, não pode querer determinar por completo os objetos; ele tem de determiná-los e tem também de, ao mesmo tempo, respeitar essa indeterminação que lhe é constituinte e que lhes fornece seu movimento. O conceito, ao sofrer o impacto da experiência, deve internalizar a resistência do objeto.

O conceito tem um movimento [Bewegung], e seu motor é a inquietude [Unruhe], o motor psicológico da progressão fenomenológica. A inquietude é a relação entre saber e formação; formação como tomada de consciência daquilo que é racional e como capacidade da consciência de agir em várias esferas da vida social. É a negatividade que impõe um movimento ao não estar tranqüila. A inquietude, própria ao pensar especulativo, é a verdadeira negação dialética ${ }^{10}$. A dúvida é sempre uma comparação entre uma situação duvidosa e uma situação de certeza. Ainda assim, a dúvida não duvida das condições da certeza. Como posso ter certeza da minha certeza? E se eu duvidar dos critérios da certeza? E se a luz da razão me produz um jogo de sombras? A conclusão a que chega a razão, no final das contas, é que existem objetos opacos, e que a linguagem deve respeitar esta falta de clareza. Os objetos resistem ao serem conhecidos; têm uma resistência que lhes é interna, que é constitutiva do saber e que produz seus limites; para o qual o fracasso pode ser a única forma de realizar um conceito. Isto ocorre, afinal, porque os objetos não são estáticos, senão plasticidades que não se fixam em configurações estáticas. Há uma negatividade no campo da empiria, isto é, existem objetos que são negativos em-si. Há uma negação em-si; daí a exigência de uma nova gramática filosófica, a qual deve assim ser a manifestação do próprio conceito. Em face de objetos contraditórios em-si mesmos, o abandono do regime de transparência da linguagem torna-se imperativo (Safatle 2006, p.121) - já que a Filosofia não é um discurso somente de conteúdos, mas também das formas. O discurso

\footnotetext{
${ }^{10}$ Esta inquietude é um dos fatores que aproxima Hegel dos Céticos. Hegel quer internalizar em sua dialética o ceticismo como um de seus momentos, pois os céticos, diz ele, estavam certos ao mostrarem o desespero das certezas. Em poucas palavras, o projeto dialético reconhece que o ceticismo não foi suficientemente cético. A dialética é, em grande medida, levar o ceticismo aos seus limites a fim de moer todos os significados.
} 
passa então a querer dizer o que se apresenta em desvanecimento e o que somente aparece desaparecendo.

Existe um movimento da Coisa-mesma que é inadequadamente apreendido pelo discurso. Ao pensar a coisa-em-si, eu me deparo com uma contradição real, uma contradição sobre o mesmo aspecto ${ }^{11}$. Eliminar a contradição do discurso só faz a consciência perder algo da experiência. O discurso, corroído pelo próprio objeto, tem que absorver a contradição. A contradição é própria à Coisa ${ }^{12}$ [Sache], e não é indeterminação; é constitutiva da Coisa-mesma e o discurso deve apreendê-la. A razão moderna, como atividade que é, sabe que há uma inadequação entre reflexão e experiência, entre teoria e práxis, entre discurso e prática, e, por isso, exige uma reformulação da teoria. A dialética quer dar a forma do conceito ao que parece se apresentar como não-conceito: "o problema hegeliano consiste em saber como apresentar o que é vazio de conceito em uma determinidade conceitual, e não como anular o não-conceitual através do império total do conceito. É possível conservar o não-conceitual sem entrar em sua hipóstase? Eis uma problemática hegeliana por excelência. Como bem sublinhou Mabille (1999), há, no interior mesmo da ontologia hegeliana, um risco de indeterminação que sempre devemos inicialmente assumir para poder após conjurar" (Safatle 2006, p.142).

O conhecimento da relação não se dá previamente à experiência, não é dado a priori. $\mathrm{Na}$ condição assegurada na experiência não existe estrutura do saber assegurada de antemão. Para Hegel, não há nada a priori. O que pode ocorrer é que uma estrutura apareça como a priori para a consciência. $\mathrm{O}$ descompasso entre sujeito e objeto gera a dúvida, e, mais do que isso, gera desespero (figura claramente psicológica), ponto de partida em direção ao fundamento.

$\mathrm{Na} \mathrm{FE}$, o saber se diferencia totalmente da intuição: não há revelação do absoluto, mas sim produção do absoluto. $O$ absoluto não se intui, se produz. A verdade performativa de Hegel concerne justamente à idéia de que o saber produz seus

\footnotetext{
${ }^{11}$ Este é um ponto importante. A contradição não está entre dois aspectos distintos da coisa, mas no mesmo aspecto.

${ }^{12} \mathrm{O}$ conceito de Coisa é duplo em Hegel e foi traduzido respectivamente em dupla forma: (a) como Sache é "Coisa", coisa trabalhada pela consciência ou pelo Espírito, que articula aparência e essência e é independente de um outro; é a coisa reconciliada consigo mesma e; (b) e, como Ding é "coisa", coisa como se apresenta brutalmente, imediatamente.
} 
objetos, e, por isso mesmo, pode haver adequação entre Saber e Ser. O mundo é produto do saber; não há nada que fique "fora" dele. Os objetos não estão dados e nem se trata de meramente "descobri-los". O conhecer conceituante é o conhecer que estabelece relações de identidade e de diferença.

Para a dialética o conceito não é um operador constatativo porque a verdade não é algo que se revela, como se fosse um tesouro enterrado. O conceito não tem que se adequar ao que "já existe e permacene por ser desvelado". O conceito é um operador performativo pois instaura um processo, no interior do campo da experiência da consciência, capaz de produzir modificações estruturais na apreensão do mundo posto. O conceito cria, produz. Ele divide o que parecia indivisível (crítica ao princípio de identidade) e unifica o que parecia oposto (através da internalização de negações) (Safatle 2006, p.117).

Segundo Hegel, Kant operava com uma gramática da finitude e absolutizou o finito ao usar a noção de representação como ausência de uma presença, como um genérico para representar a multiplicidade de casos. Contudo, diz Hegel, o finito é aquele que se autoanula e, se o deixarmos por si só, ele só se anulará. O finito Kantiano seria, desse modo, um erro gramatical que não encontra identidades onde há diferenças, e nem diferenças onde há identidade. $\mathrm{O}$ entendimento é a finitude da razão humana. Hegel não aceita a noção de representação, pois o próprio representar, este pôr-diante-de-si, já muda a organização mental do mundo. A tarefa hegeliana é expor a contradição dentro do finito, já que a tematização da experiência nos obriga a abandonar as categorias do entendimento. A negação não é uma privação, como afirma Kant. O medo do erro, afirma Hegel, é o medo da verdade - ou melhor, o medo do erro já é o próprio erro. Mas, o que é um modo do saber não determinado pelo medo do erro? O erro já é caminho da verdade, e não somente uma inadequação entre ser e pensar. A tematização do outro da razão é o caminho para encontrar o erro da razão, que tem seu saber em um outro, mas que não o expulsa para além de si-mesmo; o racional nunca exclui.

Ademais, Hegel também se dirige contrariamente a Aristóteles. Aos olhos da filosofia especulativa, este último só fazia ciência do universal e do geral, como aquilo que permanece imutável, ignorando os particulares e contingentes. O movimento, como já postulava Zenão, não pode ser apreendido pela ciência. A filosofia, assim como 
expresso no conceito de taxionomia, deve se contentar com as regularidades e com os gêneros $^{13}$. Trata-se de aplicar as leis aos casos. Para Hegel, ao contrário, a figura da aplicação é inadequada para a Razão. O processo fenomenológico é oposto ao da aplicação. Hegel, ao suspender as dicotomias kantianas e a categorização aristotélica, deseja operar a passagem do representativo (jogo de figuras) para o especulativo (desenvolvimento dos conceitos). Posta em termos alternativos, a crítica de Hegel a Kant é a de que este tomava o conhecimento por um instrumento ou meio de conhecer (Menezes 1992).

O finito é o condicionado, o conhecer condicionado, algo cuja verdade é condicionada. Trata de aplicar predicados aos objetos. O saber finito não é absoluto, ainda que absoluto não signifique explicar toda e qualquer contingência; absolutização não implica anulação das contingências, nem transformar as contingências em necessidades. O finito é condicionado pelo saber da consciência, pelo tempo e pelo espaço, pelas “condições para saber algo". O infinito, ao contrário, é o incondicionado, o universal. É a unidade na diferença. Para que ele se manifeste, nada é necessário, pois ele já aparece: “A infinitude, ou essa inquietação absoluta do puro mover-se-a-si-mesmo ... já era, sem dúvida, a alma de tudo o que houve até aqui” (Hegel 2002, §163). É aquilo que porta em-si mesmo sua própria negação, mas que se conserva em uma determinidade. $\mathbf{O}$ infinito é a alma da dialética. Entretanto, existem, para Hegel, dois tipos de infinito: o "ruim" (como o infinito do entendimento, o infinito matemático), e o "verdadeiro". O mau infinito é aquele que nunca está pleno, é o infinitamente numerável, é o infinito quantitativo, a passagem incessante de oposto a oposto própria das antinomias. O bom infinito, o infinito verdadeiro, é a pulsação de identidade e da diferença em uma determinidade; é o desejo que vai além de si mesmo e que passa por uma modificação qualitativa, quase como uma contradição bem resolvida. A idéia de infinito mostra como duas proposições contrárias podem produzir um objeto (Hegel 2002, §§162164).

13 John Locke assim raciocinava para lidar cientificamente com os dados econômicos. Dizia ele, referindo-se à taxa de juros de mercado (que oscila conforme variações na oferta e na demanda de moeda), que o problema é entender a regularidade não imediatamente observável. Ou seja, a ciência não deve ser ocupar do que é oscilante (os particulares), mas sim do que é regular (o universal) detrás destes movimentos aparentes. A taxa de juros de mercado não é o problema lógico a ser tematizado, senão o problema mais difícil da "taxa de juros natural". Neste sentido, os particulares perdem sua dignidade em face ao universal. Contrariamente a isso, a dialética hegeliana é, em grande medida, o resgate da dignidade dos particulares e o entendimento de que o universal não é algo fixo, senão o próprio movimento. 
A linguagem especular, especulativa, é necessária para a noção performativa da verdade - em oposição à verdade como adequação ao objeto. A linguagem precisa dar conta da capacidade produtiva do conceito, de um conceito que de fato produz a realidade. Trata-se, desse modo, de uma internalização de um processo de confrontação em que não há nada para-além. O conceito já está para-além-de-si-mesmo. Há, assim, uma demarcação clara: se o pensar representativo trabalhava com representações, o pensar especulativo trabalha com conceitos. $\mathrm{Na}$ dialética hegeliana, o operador lógico fundamental é a negação determinada. Neste ponto, faz-se necessário distinguir:

(a) Contradição: é uma relação interna a cada termo. A determinação de cada termo é contraditória. A contradição desubstancializa a identidade e a relação interfere no próprio sentido dos termos isolados;

(b) Contrariedade: é uma relação entre termos opostos e diz respeito à figura da oposição. A relação não muda o sentido dos termos e os objetos somente são entendidos em relação uns aos outros.

Colocada em outros termos: "a oposição não pode admitir que a identidade de um termo é a passagem no seu oposto, que o limite de um termo, por ser seu limite, faz parte da extensão do próprio termo. No entanto, a negação determinada significa exatamente isto: que o termo, ao realizar-se, ou seja, ao se referir à experiência, passa necessariamente no seu oposto e esta passagem é, ao mesmo tempo, a perda do seu sentido e a realização do seu sentido" (Safatle 2006, p.131).

Assim entendido, nos escritos de Hegel podemos encontrar três níveis de negação (idem, p.132):

(a) Negação simples ou abstrata: refere-se a uma simples oposição ou contrariedade que impede a passagem nos contrários ao não perceber a relação “solidária" entre as figuras. É uma privação, um limite, um simples não-ser. Ao organizar as oposições, só põe um termo pressupondo seu oposto em uma relação de exterioridade com este. Acaba por naturalizar um estado de coisas com sua forma de determinar por oposições; 
(b) Negação absoluta: é forma indeterminada e intermediária entre a negação simples e a negação determinada. Mostra que a negação simples não se sustenta. É um modo de desestruturação e de confrontação com a indeterminação;

(c) Negação determinada: quando se refere à inversão [Verhkerung] ou à interversão [Umschlagen], pode produzir oposições ad infinitum e a passagem incessante nos opostos sem atingir a Aufhebung; é uma inversão que pode ser bloqueada, uma dialética bloqueada; esta negação pode levar ao "mal”, um processo que não se realizou por completo, um processo obstado que se interverte em seu contrário ${ }^{14}$; a passagem no oposto é perda de sentido e realização de seu sentido. Mas quando se refere à superação [Aufhebung], diz respeito a uma negação produtora; uma negação que pode produzir um ser. Torna-se uma retenção, sem passagem nos opostos, como movimento interior, e não entre dois pólos. Para a figura da Aufhebung, o que era externo foi posto como interno; o não-ser torna-se movimento do ser; todo termo posto passa no seu oposto e onde havia uma diferença, surge a identidade ${ }^{15}$.

A negação produtora, negação determinada como Aufhebung, é uma negação que opera supressões exatamente para pôr fim às interversões e para efetivar uma determinação sem invertê-la em seu contrário. A dialética é, posta em termos diferentes, um espírito de contradição organizado, sendo a negação determinada figura central. É esta negação que estrutura as relações de objeto, relações conceituais, relações de passagem a opostos. Não é um modo de relação entre objetos, mas sim entre conceito e objeto; é uma apreensão de processos, e não uma dedução prévia de representações. Se a consciência, ao pôr a identidade, passa à diferença e se, da mesma forma, a modernidade se mostra como a experiência da não-identidade da subjetividade, a dialética hegeliana visará explicitamente reconstruir a idéia de identidade como

\footnotetext{
${ }^{14}$ Vejamos um exemplo. Qual a diferença nos usos do verbo "ser" nas seguintes frases: "A mulher não é alta" e "A mulher não é homem"? Na primeira, o verbo "ser" indica uma predicação e trata-se de uma negação indeterminada, pois se eu nego o predicado, não obtenho o sujeito (é, assim, uma contrariedade). Na segunda frase, o verbo "ser" indica uma identidade e trata-se de uma negação determinada, pois se eu nego o predicado, tenho o sujeito; passamos de um termo ao outro

${ }^{15}$ Muitas vezes, ao não se ter em conta o que é de fato uma exposição dialética, alguns marxistas parecem não captar toda a riqueza da seqüência das formas e dos predicados do capital. David Harvey é um exemplo de como se confunde negação dialética com negação simples: "Marx's view [is] that money has to be understood independently of the circulation of capital" (2007, p.240). Erro que provavelmente decore das teses de Brunhoff de que a circulação monetária seria um universal (uma suposta "sociedade monetária") do qual o capitalismo seria uma de suas particularidades. Fausto (1987a, 1987b e 1997) soluciona este problema com uma leitura dialética: a circulação simples é a aparência do capitalismo.
} 
identidade que inclui em-si o seu outro ao desejar apreender a diferença dentro da própria unidade.

Para entendermos o que é uma negação e a passagem dos contrários há que se entender em primeiro lugar que o tempo presente tem certa "espessura" que nos impede de assimilá-lo como um conjunto de pontos, ou seja, de apreendê-lo através de uma noção pontilista de tempo. Se entendermos o tempo como uma sucessão linear de vários tempos pontuais, assim como fazemos como o espaço, não entenderemos o que Hegel de fato quer dizer. Na dialética, não podemos mais transpor ao tempo a estrutura do espaço. O tempo se revela como aquilo que não sendo é. A tarefa consiste, então, em desenvolvermos uma apreensão dialética do tempo. O tempo deve deixar de ser apreendido como espaço para ser apreendido enquanto movimento.

A consciência, ao tentar determinar a referência do conceito, acaba por ver seu objeto passar em um outro. Ela, assim, não consegue aplicar seu próprio conceito ao objeto sem engendrar a passagem a um outro. Ocorre uma problematização do que se entende por conceitualizar ao descobrir um outro que me constitui. O pensar especulativo, portanto, deve compreender como o sentido dos conceitos necessariamente se modifica ao passar à consciência. A determinação não é prévia à experiência e o sentido do processo não é algo dado a priori, mas sim pelo resultado produzido. Deve-se perguntar sobre o sentido através das formas de uso: o sentido não é um objeto fruto de uma dedução, mas sim resultado de um processo de produção do sentido. O sentido é produzido, e não deduzido. $\mathrm{O}$ conhecimento das relações, portanto, não pode ser fruto de uma dedução transcendental.

A dialética, ao rejeitar as representações em favor dos conceitos, se propõe a acabar com a dicotomia entre sujeito e objeto. Para o pensar representativo, o seu conceito é uma unificação de representações que dá a unidade a partir de abstrações. O pensar especulativo, ao reformular a noção de identidade, supera a distinção entre objetividade e subjetividade, e abandona o pensar enquanto um pensar sobre um estado de coisas. $O$ conceito especulativo não é uma abstração que organiza a experiência. Contrariamente ao que Kant afirmava, compreender a forma é já compreender o conteúdo. O conceito é uma estrutura de relação, e, portanto, entidade relacional. Não há conceito de um objeto, mas há sim representações de objetos. Para o 
especulativo, só se pensa onde a representação não alcança: conceituar é pensar para além das representações, e, assim, exige a superação do uso degradado da linguagem. Toda a filosofia de representação já está embrenhada na gramática do senso-comum (de sujeito-predicado, de causa-efeito, etc.). Há que se pôr um novo regime de sintaxe que supere a gramática das representações.

A negação vem de dentro do conceito: ao tentar afirmar a tese, somos levados a negála; ao realizar a tese, acabo por realizar o seu oposto. A antítese não vem do além, de fora, não é externa, senão produzida pela tese; é sua realização que a nega. Procurava-se a tese, mas encontramos sua antítese ao realizar o seu próprio conceito. Se para o entendimento não há a possibilidade de que um termo posto passe nos seu oposto, na lógica dialética a determinação de um termo é sua posição como negação de um outro, e essa negação determinada nos permite estruturar relações do objeto. A implementação da tese produz sua anti-tese, seu contrário, que não é um objeto externo, mas produzido internamente pela tese; é a sua própria realização interior. A negação da tese é sua própria produção e sua realização.

\section{A dinâmica da inadequação não ocorre entre um objeto e um conceito exterior que a ele é impingido. A inadequação se dá entre o objeto e o seu próprio conceito interior. $O$ objeto tenta realizar o seu conceito e, ao fazer isso, se nega. Faz-se necessário, assim, escapar do primado da positividade e refazer a noção de negatividade. Se para os pré-hegelianos, a negação não tinha realidade em-si, com Hegel surge o resgate da dignidade ontológica do negativo, do negativo com estatuto de ser, de uma negação que tem um ser que lhe é próprio: "uma das dimensões deste trabalho de internalização do que é em-si negativo nos leva a compreender o conceito como aquilo capaz de formalizar o que podemos chamar de contradição objetiva" (Safatle 2006, p.137). O que implica dizer que uma contradição lógica é uma contradição social.}




\subsection{Fenomenologia e Formação da Modernidade}

A tarefa hegeliana por excelência é evidenciar o processo de formação da subjetividade moderna, o que implica mostrar o que é ser necessário para que a subjetividade se coloque no fundamento da Razão. A modernidade tem um projeto que encontra-se em gestação desde a perda da eticidade na Grécia; importa saber em que condições esse projeto pode se realizar. Hegel, em seu sistema, quer pôr o sujeito como fundamento ou, dito de maneira alternativa, quer apreender a substância como sujeito.

O objeto de reflexão é, assim, a própria modernidade, um momento de cisões - entre aparência/essência, entre o para-si e o em-si, entre universal e /particular, entre sujeito e objeto etc. - e um momento demandante de uma auto-certificação que não permite procurar suas explicações em épocas passadas. O diagnóstico é o de que não podemos mais buscar as normas e fundamentos em outras épocas, mas que devemos sim buscálos na própria modernidade. Problema este de auto-certificação que implica tematizar os fundamentos do processo de modernização, de racionalização social e dos princípios de subjetividade. O problema posto é o da necessidade de reconhecimento intersubjetivo.

Assim como Weber, Hegel afirma que a substancialidade foi perdida, que o espírito perdeu sua imediatez substancial. Como resultado da Revolução Gloriosa, da Reforma Protestante, da Revolução Francesa e do Iluminismo, a modernidade evidencia a tensão entre a universalidade da lei e a singularidade do indivíduo. Como reconstruir a subjetividade na modernidade? Como colocar o sujeito como fundamento? Como apreender a substância como sujeito? Como reconhecer as singularidades? Na modernidade o sujeito tem à sua disposição a possibilidade de pôr reflexivamente a rede de causalidade social e pode então perceber que há uma inadequação entre suas expectativas e as representações que tomava como seguras. A verdadeira crítica da razão é o diagnóstico das formas de vida.

Para Hegel não existe diferenciação absoluta entre as produções dentre os vários campos do saber, havendo, de igual modo, um contínuo entre as idéias das diversas esferas de valores. Traçando uma comparação sobre os diagnósticos da modernidade, poderíamos advogar que: 
(a) em Weber, a modernidade é um momento de autonomização das esferas de valores, sem um elemento ou poder unificador; fato constituinte de um "desencantamento do mundo" em que cada esfera social tem sua própria valoração. Na modernidade, os mitos perderam sua função unificadora.

(b) em Hegel, ainda que exista uma desagregação da vida moderna, em que cada indivíduo apareça ligado à sua função social, há um elemento unificador que opera como um padrão geral de racionalidade compartilhado e ordenador de todas as esferas de valores. A questão é apreender este momento em uma perspectiva reflexiva na modernidade ${ }^{16}$;

(c) em Marx, esse elemento unificador de todas as esferas sociais é a forma capital.

Dentro da abordagem marxista, o moderno uso dos derivativos nos fornece um claro exemplo de como a forma capital fornece este eixo balizador de todas as esferas sociais. Segundo a teoria neoclássica, os derivativos financeiros são um meio de gerenciar não somente riscos corporativos, mas também riscos sociais e pessoais. E, como evidencia Shiller (2003), o este uso não tem limite que a imaginação não conceba, extrapolando todas as fronteiras de um suposto "campo econômico" e, acrescentemos, opostamente a qualquer perspectiva weberiana de "desencantamento do mundo".

A história da filosofia, segundo Hegel, é a história da subjetividade permeada por uma indeterminação como elemento constitutivo fundamental. A modernidade deve, assim, dar a estrutura institucional para o reconhecimento da liberdade da subjetividade, isto é, deve dar estrutura ao indeterminado. Este é o saber absoluto. Um saber que não é absoluto porque pensa tudo, inclusive os contingentes, mas é absoluto porque respeita a

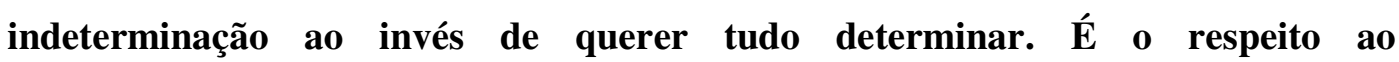
indeterminado, ao negativo. $\mathrm{O}$ indeterminado é indeterminado porque é perpassado pela negatividade. A consciência parte de pré-condições e de conhecimentos prévios, mas a experiência fenomenológica faz o favor de dissolvê-los. Todo processo de determinação é, portanto, a confrontação com o indeterminado. ${ }^{16}$ Contudo, entre Weber e Hegel parece haver um ponto em comum: ambos querem entender a
modernidade como uma totalidade a partir das vontades e visões particulares. 
Se o absoluto do saber é a adequação completa entre saber e objeto, isto não se confunde com o saber absoluto de Hegel. Este último não diz respeito a uma dedução integral do saber e de qualquer contingência. $\mathrm{O}$ reconhecimento do contingente é o reconhecimento do que é exterior ao conceito. O saber absoluto é o saber da infinitude, é a determinação do objeto que traz a indeterminação; é um regime de saber para o qual a determinação absorve a indeterminação. Não é a determinação de tudo, mas o respeito à indeterminação. Para a dialética, a determinação nunca é completa. O saber determina e internaliza a negação, onde a identidade não é estabelecida, mas evanescente. Hegel trabalha, portanto, com um "conceito ontológico de negação como modo de manifestação do que é essencialmente determinado" (Safatle 2006, p.111). E, mais do que um ser ontológico (Lebrun 2006), a negação é um problema prático a ser enfrentado pelo sujeito (Brandom 2002).

Hegel quer submeter as expectativas da razão e as exigências de racionalização a um processo histórico de constituição da modernidade, justamente apreendendo a indeterminação própria do Sujeito. Hegel deseja procurar na subjetividade o fundamento da razão, isto é, que o sujeito deve ser apreendido como substância e como aquilo que faz com que o espírito se mova e que sempre esteja inquieto. O sujeito é a indeterminação substancial, é aquilo que aparece como negatividade. O movimento da substância e do sujeito está justamente em sua negatividade.

O que fundamenta a experiência fenomenológica é um processo totalizante de constituição, onde o fundamento precisa ser posto e o negativo elevado ao ser. O texto hegeliano é, assim, atravessado pela negatividade como operador lógico básico ${ }^{17}$.

Desde a primeira versão da FE, então intitulada "Ciência da Experiência da Consciência", o objetivo primordial era descrever a divisão entre o Absoluto e a consciência e a superação desta cisão, o devir do saber, a reconciliação entre pensar e ser, no qual o princípio de subjetividade serve de fundamento da racionalização através de um longo e árduo caminho da experiência. A fenomenologia traz a intranqüilidade quando nos sentimos mais confortáveis, ela introduz o desespero justamente ali onde acreditamos agarrar algo sólido; ela, mais do que trazer novos argumentos ainda

\footnotetext{
${ }^{17}$ A "natureza evanescente da referência em Hegel significa admitir uma modalidade possível de relação entre palavra e coisa através de uma negação pensada como modo de presença” (Safatle 2006, p.136).
} 
desconhecidos, vem a desestabilizar aquilo que tomávamos por mais seguro. A contradição vai se impondo à consciência e a experiência leva a consciência a questionar suas certezas ditas inquestionáveis. A FE expressa, desse modo, a necessidade de constituirmos uma nova ordem lógica. É neste sentido que podemos, então, afirmar que a formação da modernidade é também a formação da lógica.

O impasse do reconhecimento, um problema eminentemente prático, leva a dialética enquanto linguagem a desconfiar, portanto, que a própria linguagem sirva para se comunicar. O senso-comum se revela como metafísica e como espaço ideal para as representações naturais, isto é, para a naturalização de um discurso filosófico. O problema da consciência não é com o desconhecido, mas com o que é julgado como bem conhecido, com o que é tomado por seguro, estável e, por isso mesmo, não tematizado. "A dialética é dependente de um questionamento a respeito dos modos de funcionamento da linguagem em suas expectativas referenciais, ela nasce através deste questionamento e da maneira como tal problematização das expectativas referenciais da linguagem nos obriga a rever conceitos ontológicos centrais" (Safatle 2006, p.122). A dialética vai tematizar o que a consciência tomava por mais certo. A linguagem filosófica, que ocupa um lugar privilegiado nesta dinâmica, deve operar no seu ponto de tortura, de torção.

\subsection{A Gênese Prática e Empírica do Conceito}

A lógica é, acima de tudo, uma relação social. O sujeito cognoscente somente consegue criticar certos princípios lógicos a partir da tematização de processos sociais. Os problemas sócio-políticos são problemas lógicos, e os problemas lógicos devem ser problematizados como problemas sociais. Para a filosofia hegeliana, todo problema social é ontológico. Dessa forma, se a consciência continuar a operar com estruturas descompassadas com as relações sociais, ela se perderá em ilusões. Marx, assim como expresso na Introdução de 1857/1858, concorda com Hegel: "as categorias exprimem portanto formas de modos de ser, determinações de existência" (Marx 1982, p.18 ênfase nossa). 
Hegel questiona a consciência em sua dimensão prática (Brandom 2002) ${ }^{18}$. A crítica é sobre as formas de vida, e não somente sobre as formas de pensamento. Se com Kant só havia experiência a partir de categorias transcendentais, o pensamento especulativo Hegeliano é a crítica da metafísica da identidade a partir da idéia de gênese empírica do sujeito (Brandom 2002 e Safatle 2006). O pensar já é uma práxis, já é uma ação.

$\mathrm{Na}$ FE percebermos que o conceito hegeliano de sujeito tem uma gênese empírica, isto é, há uma experiência material da constituição do sujeito: “for Hegel all transcendental constitution is social institution" (Brandom 2002, p.216). Ou melhor: "Hegel ... está claramente disposto a mostrar como o conteúdo semântico do conceito é determinado pela experiência feita pela consciência. Experiência que não é outra coisa senão práxis que visa a conceitualização do que aparece. No entanto, esta experiência só será tematizada de maneira adequada quando compreendermos como ela se realiza naturalmente na determinação de categorias ontológicas. A dimensão ontológica da negação deve orientar a experiência da consciência, quer dizer, ela deve se revelar no interior das operações práticas dos sujeitos" (Safatle 2006, p.111 - ênfase nossa).

Na seção "Consciência" da FE, nos é apresentada a relação cognitivo instrumental entre sujeito e objeto. A consciência parte do nível mais fundamental: do saber imediato e do saber do imediato. Trata-se, portanto, de sujeitos individuais se confrontando com objetos independentes em um conflito entre consciência subjetiva e verdade objetiva, onde a consciência acredita que verdade $=$ certeza. $\mathrm{O}$ seu critério para a verdade é a certeza. Entretanto, a consciência tem a experiência da impossibilidade de seu objetivo inicial de saber imediatamente. Ela tenta implementar o conceito de saber imediato mas depara-se com um objeto que não se adéqua ao seu conceito de imediaticidade. A intencionalidade se inverte ao ser realizada. A consciência tem um conceito de experiência que é seu motor e que, no entanto, não se realiza. A consciência descobre que por trás da imediatez existe uma rede de mediações. A pura intuição revela-se como pura mediação e a consciência percebe que o conceito de experiência não se adéqua à sua própria experiência. Isto porque não há significações privadas; elas são

\footnotetext{
${ }^{18}$ O objetivo central de Brandom (2002) é aproximar ontologia e pragmática em Hegel.
} 
um fato não-intencional e não dizem respeito a um estado mental, mas sim a um fato social vinculada à práxis.

Com a "Percepção" o sujeito se dá conta de uma rede de oposições; percebe não apreender o objeto de fato sem apreender o campo (estrutura) de apreensões. Ao querer tomar o objeto, descobre tomar um estado de coisas, e não coisas isoladas. A percepção apreende relações entre coisas. As propriedades que julgava serem do objeto se mostram como propriedades da relação entre sujeito e objeto. E este é ponto nevrálgico: a consciência percebe a distinção entre fenômeno [Erscheinung] e coisaem-si, e ao confrontar-se com a cisão do objeto, se confronta automaticamente com a estrutura do saber cindido. A consciência vai deixar de falar de objetos para falar do próprio saber; vai pensar sobre o seu modo de pensar. É a cisão do objeto em fenômeno e coisa-em-si que leva a consciência a duvidar da estrutura do saber. $O$ imediato não está mais ao alcance do saber; não é mais possível obter conhecimento direto, sem mediações. A consciência assimila a distinção entre aparência e essência e também vê que a essência do ser está ligada à sua apreensão imediata. A imediaticidade é um momento da essência do ser que ainda não acedeu à palavra. Há, desse modo, uma gênese da coisa-em-si e há uma gênese do universal a partir do sensível.

Para a consciência assentada na percepção, conhecer é sinônimo de predicar, e verdade é sinônimo de adequação entre representações e efetivo. A crença era de que o objeto seria dado em sua imediaticidade e em sua particularidade. Mas esta crença se inverte, pois descobre a linguagem como mediadora. $\mathrm{O}$ imediato se perde na descoberta do mediato. A consciência não realizou o seu próprio conceito ao tentar aplicá-lo. A figura superior do entendimento é a apreensão de que exige algo mais do que a percepção mesma. Agora, a consciência sabe que não pode assimilar o objeto sem mediações, e principalmente, sem a mediação da linguagem. A gramática filosófica passa a depender da idéia de essência e aparência, ou seja, de uma nova gramática da presença. A presença, para a dialética, é o desaparecimento do desaparecer. A verdadeira determinação se dá onde se apreende os objetos em desvanecimento, em sua fluidez. Como diz Ruy Fausto (1987a) onde nenhum termo está totalmente presente, só há significações fluídas: a dialética, assim, quer pensar a determinação em movimento e a indeterminação fundante. 
O campo da manifestação é a integralidade da verdade; não há verdade que não apareça, pois aquilo que existe é o que se manifesta. Isto é: o que não aparece simplesmente não existe. A consciência constituiu um modo de pensar a cisão potência/ato, mas acabou por criar a cisão do em-si e do para-mim. Neste sentido, a FE é, em grande sentido, a reconstituição da noção de fenômeno (Hegel 2002, §147, p.118); é o ser da força desenvolvido, ainda como algo que desapareça. É em-si mesmo um nãoser, é ser que é imediatamente não-ser, que, para o entendimento, constitui-se no evanescente. É o ser que traz em-si as marcas do não-ser. O fenômeno aparece com suas inadequações em relação à essência e se realiza como fracasso ou inadequação. Mas já determina algo da essência, mesmo que ainda um puro-além. A dialética, portanto, abandona a noção de pura aparência, ainda que a essência, ao exteriorizar-se pela primeira vez, pareça ser pura aparência. O fenômeno, marcado pela negatividade, é a essência do supra-sensível. O não-ser é a essência do ser, ou seja, há um ser cuja essência é negativa.

Como vemos, o Eu precisa do conceito de fenômeno porque nem tudo aparece de maneira imediata. Existe uma experiência de negatividade que é um modo de manifestação da essência. Aparecer é surgir para re-desaparecer, é um surgir que não tem essencialidade, já que o que aparece não é a integralidade da essência. Mas o fenômeno não exprime imediatamente a essência, apesar de ser já um modo da essência, cuja negatividade (inquietude) lhe é natural. $\mathrm{O}$ entendimento opera, portanto, com uma dicotomia entre sensível e supra-sensível; mas para a dialética, não há tal cisão rígida entre estes termos. Quando a percepção do fenômeno não dá conta da integralidade da essência, nasce a idéia da coisa-em-si. Haveria algum limite do em-si? Haveria limite para a razão? Hegel deixa claro que não há nada fora da experiência e que não há nada para além da consciência. A questão é que não há ainda uma gramática filosófica adequada a tais cisões postas pela modernidade.

Hegel quer mostrar como a noção de igualdade é contraditória e que a consciência não sabe direito o que fala quando põe a igualdade. A idéia é a de que uma relação de igualdade não põe a igualdade de fato. A relação de igualdade advém problemática e a consciência vê seu mundo ruir, já que não sabe mais o que é conceitualizar. Ao perceber que não mais sabe o que diz, a consciência vai buscar refúgio na idéia do “mundo invertido". Isto é, na idéia de que as coisas se apresentam de maneira invertida: 
o primeiro estado é o fundamento, o essencial; o segundo estado é o invertido. O significado é dado pelo primeiro estado, o fundamento, e a inversão aparece como uma astúcia da conservação. O mundo não realizou as expectativas da consciência, então ela o inverte. As leis são invertidas, mas a transvalorização não sai do mesmo lugar. $\mathrm{O}$ fundamento negativo do segundo mundo é o primeiro, já que mantenho o não-invertido como guia do mundo invertido. O verdadeiro aqui é o não-verdadeiro lá; a essência está na negação do primeiro mundo (o guia). Diz Hegel: esta passagem não é dialética, pois a diferença não é interna, mas sim externa. A concepção do mundo invertido é uma forma geral de crítica que deve ser descartada, pois o que de fato devemos criticar é a nossa própria concepção de objeto.

Disto se segue que tampouco devemos tomar a relação base/super-estrutura de Marx como uma questão de mundo invertido, pois se assim fosse não haveria produção de um pólo pelo seu outro, mas sim uma mundo que é o mundo de fato (a base) e a sua inversão ilusória (a super-estrutura). Se assim fosse tratar-se-ia de dizer que a base é o fundamento e que a super-estrutura é sua inversão, mas que mantém a base como fundamento positivo. Neste caso a dialética é posta de lado e ficamos com um jogo de opostos externos, que o entendimento não tem problemas em apreender. Contudo, não é isto o que está em questão, pois dessa maneira não apreendemos a contradição.

A necessidade é reconceitualizar a coisa, o objeto, através de uma crítica sintática e não meramente semântica. A consciência não consegue mais produzir explicações, e não usa mais relações de igualdade. O que perdeu a igualdade vai ser invertido. A consciência, para realizar o conceito do entendimento, chega a um conceito não-sensível e a um mundo duplo entre o sensível e o supra-sensível. Se se anula o supra-sensível, perde-se a capacidade explanatória. A solução, então, passa a ser a anulação da igualdade. Com isso, a consciência é levada à idéia de infinitude e à função da linguagem especulativa, pois percebe que expor o objeto de modo contraditório lhe aproxima mais do objeto. A noção dicotômica dos "dois mundos" ou do "mundo invertido" não deixa a consciência apreender a contradição. A dialética deve passar da inversão à contradição. E, de maneira alguma, essa contradição será um limite para a razão. É possível constituir um objeto a partir da contradição. Aqui, como veremos, Hegel aproxima a noção de infinitude e a de contradição. E, mais do que isso: a consciência deve 
apreender o caráter formativo da contradição. $O$ entendimento percebe a impossibilidade de sustentar sua dicotomia fundamental entre finito (fenômeno) e o infinito (essência). A tarefa passa a ser a busca da diferença interior, da oposição em simesma, da contradição. Em outras palavras, Hegel nos está dizendo que a consciência tem duas alternativas ao ver o seu mundo desabar frente ao finito: pensar no mundo como mundo invertido, o que constitui uma má saída, ou passar ao conceito de infinito, o que constitui a solução adequada. O mundo da consciência que desmorona não é só um estado de coisas, mas a própria crise de legitimidade do mundo da consciência, ao perceber que há uma dicotomia na definição mesma de fenômeno.

A contradição é um nada, um objeto vazio sem conceito e impossível de ser representado; é uma operação de destruição de objetos. A constatação da consciência é a de que existem objetos que somente podem ser assimilados com proposições contrárias, como ocorre com o fenômeno, que é e não-é ao mesmo tempo. A consciência é levada pela prática a pensar em objetos contraditórios. A questão central passa a ser como pensar a oposição interna (a identidade da identidade e da diferença), isto é, como apreender objetos idênticos e não-idênticos a si-mesmos. Porém, como dizer a infinitude, esta determinidade que porta em-si sua negação? ${ }^{19} \mathrm{~A}$ infinitude é a inquietude absoluta (Hegel 2002, §163) e, ao invés de se auto-destruir, se conserva em uma determinidade e produz uma determinidade. A negação traz a plasticidade do existente; é a presença de algo em movimento. Qual a solução? Pensar o tempo como movimento, e não mais como espaço através de uma noção pontilista do tempo. A infinitude é pensada a partir da contradição e a partir do abandono da gramática da finitude.

Para a sintaxe do infinito, cada termo em-si mesmo é o contrário de si-mesmo; cada qual é um contrário de um outro, é um contrário puro, contrário-de-si. Vejamos, segundo Hegel, os três momentos da identidade dialética:

(a) Igualdade-a-si: é sustentada por uma diferença exterior. É a exclusão que fornece o fundamento e a identidade opera por exclusão. A fundamentação de

\footnotetext{
${ }^{19}$ Essa crítica de Hegel se dirige diretamente a Kant, que trabalhara a filosofia através de dicotomias e da sintaxe da finitude. Fichte, Schelling e Hegel vão tentar superar essa posição Kantiana.
} 
um passa pelo outro e só fala do outro, mas é identidade que exclui esse outro. A exclusão é o ato fundador;

(b) Diferença-a-si: como pode a diferença exterior ser internalizada? Devo admitir a realidade da contradição pelos motivos da primeira igualde-a-si;

(c) Igualdade-a-si: é diversa da primeira igualdade-a-si, pois é sustentada por uma diferença interiorizada. É identidade que inclui o outro como fundamento de si próprio.

Assim, Hegel refaz o conceito de igualdade que, como vimos, havia sido fragilizado ao se deparar com objetos contraditórios. A infinitude é a "alma da vida", a "essência simples da vida", o "sangue universal". É o fundamento originário anterior aos objetos. $O$ infinito é a unidade originária donde brotam todas as diferenças. O movimento interno ao infinito, a sua distinção consigo mesmo, o faz diferenciar-se como fenômeno e essência. O infinito já estava operando e continua operando - o que, em hipótese alguma se refere a um suposto esvaziamento da História ou mesmo a algo em direção a uma lógica da descoberta. Isto não conviria à filosofia Hegeliana, que é uma filosofia dos processos, e não dos objetos. Agora, o próprio processo se torna objeto da consciência, e, por essa razão, modifica o conceito de objeto. A própria resistência do objeto ao ser assimilado pela consciência leva-a a pensá-lo como processo.

O sujeito, não obstante, é o nome do movimento de pôr um outro dentro de si, no interior de si mesmo e ainda conservando-se como identidade. Sujeito é movimento de internalizar a oposição. Sujeito é, acima de tudo, um conceito relacional e nãosolipsístico, já que traz em si mesmo um outro. Este portar um outro em-si-mesmo é condição para que seja sujeito, para que seja o fundamento das operações racionais: "por trás da assim chamada cortina, que deve cobrir o interior, nada há para ver; a não ser que nós entremos lá dentro - tanto para ver como para que haja algo ali atrás para ser visto" (Hegel 2002, §165 - ênfase do original). 


\subsection{Da Consciência à Consciência-de-Si}

A passagem da consciência à consciência-de-si é a demonstração de como o sujeito se encontra naquilo que aparentemente há de mais exterior. Em Marx isso também ocorre: o que os indivíduos tomam por mais exterior, a mercadoria e o dinheiro, revelam-se como constituintes da própria noção de sujeito. Isto é, o que era tomado por objeto externo e autônomo mostra-se, na verdade, como elementos próprios da constituição e da formação do sujeito. Na FE evidencia-se que o que a consciência toma por racional é histórico e como o espírito é uma noção não-metafísica: é um movimento de reflexão das práticas sociais de acordo com as exigências de racionalidade (Pinkard 1996, p.9). Na ação não é a consciência particular que age, mas a consciência de um tempo. No espírito, a consciência-de-si se dissolve enquanto individualidade. O espíritoconsciente-de-si é a reflexão sobre essa significação social, uma auto-reflexão em que a gênese do produzido é tematizada. É uma reflexão sobre a origem e o processo histórico a partir dos resultados gerados a partir deles.

No Zur Kritik, Marx (1982, p.38) afirma que se apresenta como relação social o que era tido como objeto e, inversamente, que se apresenta como objeto o que era tido como relação social. E, na introdução ao livro sobre o capital dos Grundrisse, Marx retoma esta idéia: "The special difficulty in grasping money in its fully developed character as money ... is that a social relation, a definite relation between individuals, here appears as a ... purely physical, external thing” (1973, p. 239). Que é exatamente a idéia que Hegel deseja transmitir ao apresentar a passagem da consciência à consciência-de-si.

Aqui queremos colocar ênfase sobre a idéia de que as relações cognitivas são subordinadas às relações sociais, relações estas de conflito, dessimetria e de luta (Pinkard 1994). O próprio Hegel, antes mesmo de Marx, já trabalhava com a subordinação da cognição à prática social e com a gênese empírica dos conceitos. Idéias que fragilizam em certo grau certas teorias estabelecidas sobre as diferenças entre o "materialismo de Marx" e o “idealismo de Hegel”, já que aproximam significativamente o segundo em relação ao primeiro. Em Hegel, a gênese do pensar é empírica e as relações sociais têm caráter produtivo. Tudo que aparece como 
transcendental é empírico (Brandom 2002, p.216). Há uma gênese social e empírica do sujeito, do Eu.

Segundo Hegel, o saber válido é aquele capaz de pôr o que pressupõe, de expor o que orienta o pensamento, de assumir o que pressupõe, de realizar o que é sua intenção. A essência não está no objeto nem no Eu: a consciência não encontra a essencialidade nos objetos diante de si e, portanto, volta-se a si mesma para refazer o caminho da cognição. Neste sentido, a primeira parte da FE é a contínua destruição das verdades da consciência. Movimento interior no qual podemos ver que a consciência: (a) é incapaz de pôr o que ela mesma faz; (b) produz algo que não sabe; (c) não sabe o que faz, não sabe o que diz e não sabe o que sabe. A tarefa é, desse modo, reorientar a forma do seu saber em direção à adequação entre subjetividade e consciência.

A verdade se dá na adequação entre conceito e objeto. Esta é, assim, a meta idealista de Hegel: sujeito=objeto e objeto=sujeito. Ao perceber que suas estruturas naturais de representação não dão conta da realidade e nem de suas aparentes cisões, a consciência se vê obrigada a repensar-se a si própria. Em face de seus problemas práticos (Brandom 2002, Safatle 2006 e Müller 2007) de não conseguir dizer de fato o que os objetos são, ela começa, então, a duvidar de suas estruturas internas de seu pensar. A consciência, ao lidar com objetos supostamente autônomos, lida consigo mesma. Quando a consciência passa às estruturas do pensar da consciência, ela se torna consciente de si-mesma, consciência-de-si. O Eu é conteúdo e forma da experiência, e o objeto é a duplicação da estrutura da consciência-de-si. Ou, dito de maneira alternativa: quando a infinitude é objeto da consciência passamos à figura da consciência-de-si. $\mathbf{O}$ problema sujeito-objeto revelar-se-á como um problema do sujeito consigo mesmo. A consciência percebe que não consegue apreender adequadamente seus objetos e começa a duvidar da sua própria estrutura de apreensão. A consciência volta-se, então, para si mesma. Inquieta, toma a si mesma como objeto; torna-se consciência-de-si como a consciência do conteúdo do objeto de experiência. Algo da resistência do objeto, ou algo da confrontação sujeito-objeto, vai ser internalizado pela consciência. O Eu passar a ser objeto de crítica.

O Eu é locus do conflito ontológico, e não de uma identidade conceitual como pressupunha Fichte. Toda a experiência se dá no interior da consciência-de-si. E, aqui, 
já está presente uma crítica à teoria da unidade e da noção de Si e uma crítica sintática da razão: o Eu não é sujeito individual, mas um Eu a partir das suas práticas sociais com outros "Eus". Práticas sociais essas que são processo com diferenças atuando em seu interior. A operação agora presenciada é a da internalização da diferença: da relação sujeito-objeto passamos à relação sujeito-outros sujeitos, em dois níveis sobrepostos que formam a estrutura dos reconhecimentos, o inter-subjetivo e os de conhecimento de objetos. Mas, atentemos: de tudo o que vimos até agora, deve ficar claro que foi o conhecimento dos objetos que ensejou a problematização do que é o intersubjetivo. A consciência-de-si é derivada de uma gênese empírica, e não transcendental.

A primeira distinção que devemos fazer é entre verdade e certeza. Se a primeira tem um caráter objetivo, a segunda tem um caráter subjetivo. $\mathrm{Na} \mathrm{FE}$, a certeza vem a perder-se na verdade. Se agora a consciência é para-si mesma objeto, a certeza será para-si mesma verdade. A transição da consciência à consciência-de-si deve deixar claro qual o modo de organização desta última, isto é, da verdade da certeza subjetiva de $\mathrm{Si}$, da sua autoconstituição. Nesta transição ocorre uma reorientação da estrutura do saber, que passa a um novo fundamento sobre os objetos e sujeitos do mundo. A consciência é nisto um ser-outro, é um diferente não diferenciado, é o mesmo que é um outro.

Como certeza sensível, a particularidade mostrou ter sua verdade no seu inverso, na universalidade. A consciência parecia perder a objetividade e a medida do seu saber. Daí advém então sua saga para encontrar novos critérios de orientação. O objeto, ao revelar-se como antinômico, mostrou-se incapaz de ser apreendido pelas categorias do entendimento. A consciência, ao pensar que lidava com as estruturas do objeto, em verdade lidava com as estruturas próprias do saber. A consciência internaliza a diferença vinda do objeto e do exterior. O que era um problema externo passa a ser interno à consciência. Pela inquietude, tudo o que era determinado se inverteu. $O$ objeto, ao resistir a ser internalizado pela consciência, foi descoberto como uma duplicação da estrutura desta. A consciência se dá conta de que o objeto resiste à conceitualização. E, mais do que isso: a consciência julga fazer algo, descobre que realizou o contrário do que queria e ainda reconhece o que fez como o seu produto. $\mathrm{O}$ $\mathrm{Eu}$, assim, pergunta-se: por que o que aparece não se submete a um determinado regime do saber? 
O Eu, como já vimos, é aquilo que faz referência a si por meio de um outro, é aquilo que traz em-si um outro. O Eu traz em seu interior a figura da diferença, sendo a figura da consciência-de-si a que mostra a experiência inaugural desta diferença. Na seção consciência-de-si, ao ser apresentada a ontogênese das capacidades cognitivas da consciência, vemos que toda a relação inicialmente tem um caráter de conflito, de dominação - assim como ficará explícito na dialética do senhor e do escravo como experiência originária de uma dessimetria. $\mathrm{O}$ outro que o Eu traz consigo é uma outra consciência que traz um outro ponto de vista, uma outra perspectiva que relativiza a perspectiva do Eu. O outro é o que me descentra, representa o que é estranho ao meu ponto de vista. O outro é aquele que traz o conflito. Os conceitos de experiência e de consciência-de-si são os mesmos, já que consciência por si só e atomizada não mais faz sentido. A consciência tenta se consolidar como independente do objeto, mas se revela como conceito relacional. É por isso que a verdade da consciência é a consciência-desi. Os indivíduos simplesmente não existem enquanto entidades isoladas.O Eu nunca é uma pura individualidade, e por isto mesmo, está clivado entre o para-si (como capacidade de abstração dos indivíduos) e seu enraizamento social.

A FE não é um sistema de ilusões, mas de como o erro leva à verdade. O problema da seção consciência é um problema cognitivo em uma perspectiva realista. Contudo, assim como visto, tal relação entre sujeito e objeto é percebida como de fato derivada das relações de reconhecimento entre sujeitos. $\mathrm{O}$ Eu se mostra não como unidade, mas como uma relação social, como uma produção social e como uma entidade relacional. A consciência cognitiva de objetos está, assim, submetida ao reconhecimento social. As relações sujeito-objeto partem das relações entre sujeitos. É isto o que está em jogo na passagem da consciência à consciência-de-si.

A relação entre sujeito e objeto não se restringe a uma relação de conhecimento, mas de desejo e de satisfação também. A consciência-de-si é desejo em geral. Mas, o que isso quer dizer? Que por trás do conhecimento jaz o interesse e o desejo? Não, não se trata disso. O conceito de Desejo [Begierde] de Hegel pretende justamente conciliar o particular com o universal como posição da infinitude. $O$ desejo mostra que a relação cognitiva deve ser entendida a partir da prática. A passagem à consciência-de-si é uma duplicação: a consciência acredita que a estrutura do objeto replica a estrutura do sujeito. A consciência-de-si internaliza o conflito que antes era externo, entre 
consciência e objeto, e passa a tratá-lo enquanto um conflito constituinte da consciência. Não há cisão nem autonomia entre pensamento e prática. O que a consciência toma por transcendental é, na verdade, uma produção social. O Eu já é desde seu início uma instituição social. O desejo, que agora entra em cena, é o operador primeiro dos modos de socialização. A relação de conhecimento começa, assim, pelas relações de desejo e satisfação (Pippin 1989, p.148). O desejo, este motor da ação, é a maneira pela qual a consciência-de-si se manifesta pela primeira vez.

A questão do reconhecimento emerge porque a consciência descobre que o que ela tomava por certo, não mais o é. Enquanto a consciência continuar pensando que o problema é entre sujeito e objeto, um problema de conhecimento, ela deixará de conhecer sua própria estrutura. A tarefa Hegeliana é, em grande medida, fazer a consciência cética voltar-se contra si mesma. A negatividade se volta contra as estruturas da consciência. O hegelianismo é um ceticismo aprofundado, onde a lógica dialética organiza essa negatividade do real experimentada pelos céticos. Os céticos não foram dialéticos justamente porque não foram céticos o suficiente, pois não criticaram a noção de contradição, conservando-a como limite do pensável. Eles não questionam o valor da contradição e por isso mesmo não tematizaram os princípios fundamentais da lógica. Criticam as adequações do pensar mas não seus princípios. "Trata-se, sobretudo, de reconhecer a existência de uma negação que vem da resistência do objeto enquanto pólo de experiência sensível. Um pouco como Hegel, que mostrava como o fundamento da negação dialética é a negação que vem do fracasso da designação devido ao evanescimento da referência. Mas para não hipostasiar a negação em um bloqueio cético do não-saber, tal resistência do objeto, base para o primado do objeto, só pode ser posta como resistência. Posição que já é uma promessa de reconciliação" (Safatle 2006, p.138-139). 


\section{Capítulo 2}

\section{Teorias Monetárias no Século XIX}

"[...] history incessantly repeats itself. But it is amazing and perhaps a little sad to observe that economists, swayed by the prevailing humors of the hour, also repeat themselves and that, blissfully ignorant of their predecessors, they believe in each case that they are making unheard-of discoveries and building up a brand-new monetary science. However, there are some things to be gleaned from a history of analysis" (Schumpeter 1955, p.712)

O que queremos acima de tudo aqui é mostrar ao mesmo tempo a potência e as limitações da teoria monetária de Marx, cujos escritos se encontram em meio a um intenso debate teórico no século XIX na Inglaterra. Se por um lado Marx superou seus adversários, por outro seu esposamento das doutrinas da Banking School hoje se torna um de seus pontos fracos.

\subsection{Análise Real e Análise Monetária}

Trabalhar com os problemas referentes à teoria do valor e do padrão monetário como se fossem dois compartimentos estanques e independentes revela-se como a outra face do fato de admitir como independentes os lados real e monetário da economia. Neste sentido, este "lado real" autônomo não é nada mais do que simplesmente tratar a economia como um sistema de escambo, para o qual o "lado monetário" serviria apenas como um lubrificante das trocas, sem nelas interferir.

Entre os anos de 1600 e 1760, alguns avanços no que concerne à Teoria Monetária foram conseguidos através dos esforços de Becher, Boisguillebert, Potter, John Law e Quesnay; interlúdio este em que a análise econômica foi posta pela primeira vez em termos de fluxos de gastos. Ainda assim, até o final do século XVIII, a análise monetária, que até então tinha nos autores franceses (entre mercantilistas e fisiocratas) 
sua maior expressão, ainda pecava por sua fragilidade teórica (Schumpeter 1955, p.288). Em tal interregno, destacamos duas abordagens teóricas principais. Por um lado, o Metalismo (Petty, Locke, Child, Hume, Cantillon, Galiani, Montanari) como defensor da essencialidade lógica do lastro do dinheiro em alguma mercadoria, tal que seu valorde-troca seja dado pelo valor-de-troca desta mercadoria (independentemente de sua função monetária). Sua faceta prática postulava que a oferta monetária deveria ter uma relação fixa e estável e com perfeita convertibilidade na mercadoria-lastro. Por outro lado, o Cartalismo ${ }^{20}$, que não aceitava a essencialidade lógica de um dinheiromercadoria tanto prática como teoreticamente (como advogavam Boisguillebert, James Stuart, Barbon, Berkeley e John Law), era o oposto do primeiro grupo - ainda que fosse possível que alguém esposasse o Cartalismo teórico e o Metalismo prático em função de uma desconfiança sobre o funcionamento do sistema ou sobre as políticas das autoridades econômicas: alguém poderia muito bem, sem qualquer contradição, rejeitar a necessidade lógica do lastro material do dinheiro e ainda assim postular que na prática deveria imperar uma limitação à oferta monetária. Divisão esta entre teoria e prática que coloca a dificuldade adicional de classificarmos os autores entre os paradigmas existentes $^{21}$.

É verdade que para os Metalistas a necessidade dita lógica do dinheiro em ter um suporte material não passava de um simples postulado. Por que então a confusão? Se os Cartalistas já apontavam no século XVIII a não necessidade do lastro, por que a

\footnotetext{
${ }^{20}$ O Cartalismo, que em latim deriva de palavras como "sinal", "token", "signo" etc., também pode ser descrito como uma "claim theory of money", para a qual é a capacidade do Estado de decretar o que pode ser usado para pagar impostos que determina o que se constitui por dinheiro. Ou seja, o dinheiro não precisa ser ancorado por uma mercadoria produzida pelo trabalho humano, já que o aceite estatal é sua única legitimação. Tese esta que influenciou Simmel, Knapp, Innes e, mais atualmente, autores como Randall Wray, Geoffrey Ingham e outros pós-keynesianos. Neste sentido, como os desdobramentos posteriores do cartalismo irão produzir, o dinheiro estatal não é uma forma de dinheiro, senão a única e exclusiva forma legítima do mesmo. Sobre estas alegações, diz Lapavitsas que "it would not be very persuasive ... logically to identify commodity money as the original form of money, if evidence existed of the historical precedence of credit money. However, no such evidence exists (2000, p.639). Este debate, sobre a precedência histórica e/ou lógica do crédito sobre o dinheiro como meio-de-criculação, é travada nos dias atuais entre, de um lado, Ingham e Wray e, de outro, Lapavitsas e Dodd. Sobre esta discussão, recomendamos a leitura dos artigos destes autores que recheiam várias edições da revista inglesa Economy and Society: http://www.ingentaconnect.com/content/03085147/ . Lapavitsas (2005) resume bem a discussão e apresenta um boa crítica das posições de Ingham e Wray, que tentam desenvolver a idéia de um "dinheiro em geral" que tem origem nas promessas de pagamento.

${ }^{21}$ Esta divisão dos autores entre cartalistas e metalistas foi proposta por Schumpeter (1955, p.288). O que nos chama a atenção é a presença de Hume nos grupo dos metalistas, já que ele claramente expressou que tanto mercadorias quanto dinheiro não têm valores intrínsecos.
} 
insistência teórica de seus opositores? A chave é a confusão entre origem lógica e origem histórica da forma dinheiro:

“[...] it is not true that, as a matter of pure logic, money essentially consists in, or must be backed by, a commodity or several commodities whose exchange value as commodities are the logical basis of their value as money. The error involved consists in a confusion between the historical origin of money ... and its nature or logic - which is entirely independent of the commodity character of its material" (Schumpeter 1955, p.289). "[...] the historical as distinguished from the logical source of the phenomenon of money". (Schumpeter 1955, p.289).

Qual a ordem lógica a ser seguida então? Schumpeter (1955, p.717) nos mostra duas opções de exposição:

(i) “Teoria monetária do crédito": moeda $\rightarrow$ papéis inconversíveis $\rightarrow$ crédito;

(ii) “Teoria creditícia da moeda": crédito $\rightarrow$ sistema de compensações de créditos e débitos $\rightarrow$ dinheiro como um caso específico do crédito.

Contudo, continuemos.

Em 1752, no ensaio On the Balance of Trade, David Hume desenvolveu seu "pricespecie flow model". Tal modelo, que expunha o mecanismo de auto-ajuste do balanço de pagamentos, pressupunha um mundo no qual somente circulariam moedas de ouro e no qual os bancos não teriam importância significativa. Quando uma exportação fosse efetivada, o exportador seria pago com ouro, a ser encaminhado à Casa da Moeda para cunhagem. Todas as importações também seriam pagas em ouro. Se um país se tornasse deficitário comercialmente, ele perderia moedas de ouro que circulassem domesticamente e seus preços sofreriam uma queda. Se um país fosse deficitário, então algum outro país deveria ser superavitário. Nesse país, sua oferta interna de moedas em ouro seria aumentada e seus preços internos subiriam. Ou seja, o saldo comercial levaria a uma mudança nos preços relativos entre os países quando estes transferissem moedas de ouro entre si. No país com déficit comercial, as importações se encareceriam e suas 
exportações se barateariam até que o ajuste nas novas quantidades demandadas e ofertadas eliminasse o desequilíbrio comercial ${ }^{22}$.

A esta concepção Marx (1982, p.114-115) imputou várias críticas. O raciocínio de Hume, que fora originalmente elaborado em 1711 em conjunto com Montesquieu e que contava com a herança dos teóricos italianos do século XVII e do próprio Locke, fora denominado por Marx de "lei da circulação dos símbolos de valor". A crítica a ela direcionada tinha dois aspectos. O primeiro ressaltava que tal raciocínio não conseguia apreender a distinção entre moeda (dinheiro como meio) e dinheiro (dinheiro como fim), isto é, que tal teoria se prendia erroneamente à determinidade da moeda como meio de circulação em detrimento do dinheiro como dinheiro de fato, levando à enganosa concepção do dinheiro como mero sinal de valor ${ }^{23}$. Em segundo lugar, Marx afirmava, contrariamente à Hume, que qualquer investigação acerca da relação entre quantidade de meios-de-circulação e o comportamento dos preços das mercadorias deve ter como dado o valor do material que constitui o ouro. Contrariamente a isto, Hume teria estudado justamente as épocas de grandes mudanças no valor dos próprios metais preciosos, ou seja, exatamente os interregnos das revoluções na medida de valores. Essa limitação de Hume tinha uma explicação objetiva: ele simplesmente não dispunha do material estatístico necessário para analisar com acurácia o comportamento dos preços e das quantidades do meio circulante. Os dados necessários somente estariam disponíveis pela primeira vez com o pleno desenvolvimento do sistema bancário.

Contudo, Hume já expressava algo de muito mais importante para o devir da Ciência Econômica: a cisão entre o "lado real" e o "lado monetário", sendo exatamente este o ponto da maior crítica de Marx. Diz ele (1982, p.118) que Hume concebia essa relação entre massa de mercadorias e massa de dinheiro (ouro) como se cada mercadoria se trocasse como parte alíquota da totalidade das mercadorias por uma parte alíquota

\footnotetext{
${ }^{22} \mathrm{O}$ pano de fundo que instigou as teorizações de Hume soma o colapso do sistema de John Law na década de 1720, a luta contra o mercantilismo, a escalada inflacionária dos séculos XVI e XVII na Europa e a descoberta de metais preciosos nas Américas (Itoh e Lapavitsas 1999, p.7). A importância de Hume não decorre tanto da originalidade de seus escritos, pois Cantillon e Montesquieu já haviam dado argumentos semelhantes previamente, senão sobretudo da coerência e concisão que deu ao raciocínio.

23 "Mercadorias sem preço, e ouro e prata sem valor, entrando no processo de circulação - é o que pretende ver Hume. Assim ele não menciona nunca o valor das mercadorias, nem o valor do ouro, mas apenas as suas quantidades recíprocas. Locke já havia dito que o ouro e a prata têm apenas um valor meramente imaginário ou convencional; foi essa a primeira forma brutal de contradição à afirmação do sistema monetário de que somente o ouro e prata têm valor verdadeiro" (Marx 1982, p.117).
} 
correspondente da totalidade do ouro. Haveria, assim sendo, uma "equalização mecânica imaginária" entre peso total da massa dos metais preciosos e a massa de mercadorias que existem ao mesmo tempo em um dado país. Em outras palavras, Hume coloca mecanicamente as mercadorias de um lado e o dinheiro do outro ${ }^{24}$.

Além disso, a modernização econômica mostrou uma intensa evolução do sistema financeiro. Ao final do século XIX, as transações líquidas de capitais devidos aos empréstimos internacionais eram frequentemente superiores às transações de produtos da balança comercial ${ }^{25}$. A atuação do Banco Central via taxa de redesconto ou via operações do mercado aberto podia afetar a quantidade de crédito doméstico, afim de restaurar o equilíbrio do balanço de pagamentos sem que houvesse transferências de ouro. O equilíbrio externo poderia ser alcançado com variações no volume interno de dinheiro sem que o ouro saísse fisicamente do país ${ }^{26}$. O modelo original de Hume previa que o montante de ouro transacionado corresponderia ao nível do saldo comercial. Mas as evidências empíricas mostravam que isso de fato não ocorria: os fluxos eram muito inferiores em comparação aos saldos comerciais dos países. O ajuste do balanço de pagamentos, a despeito dos parcos fluxos de ouro, se dava por conta da prioridade dos governos em manter a conversibilidade em ouro, em especial os governos das maiores potências: Inglaterra, França e Alemanha. A defesa das reservas metálicas e a manutenção da conversibilidade dos meios de pagamento era o eixo fundamental do padrão-ouro: "Uma vez que não havia uma teoria coerente sobre a relação entre a política de um banco central e a economia, isso dava margem a discordâncias entre os analistas quanto a se o nível das taxas de juros estaria agravando o desemprego. A pressão experimentada por governos do século XX para subordinar a estabilidade da moeda a outros objetivos não foi uma característica do mundo do século XIX" (Eichengreen 2000, p.57-58)

\footnotetext{
${ }^{24}$ Que é justamente a solução moderna para o problema da determinação do valor-de-troca do dinheiro. Isto é, hoje a teoria marxista volta aos ensinamentos de Hume para determinar o valor do dinheiro - o que é objeto de estudo do próximo capítulo.

${ }^{25}$ Para a versão da Comissão Cunliffe, ao final da I Guerra Mundial, do modelo de ajuste comercial ver Eichengreen (2000, p.52).

${ }^{26}$ Após a década de 1870, o rápido crescimento do número de bancos privados na Inglaterra reduziu a participação de mercado de seu principal financiador. Assim, as operações de redesconto do Banco da Inglaterra minguaram frente aos seus concorrentes, refletindo em um menor impacto de variações da taxa de redesconto sobre as taxas do mercado. A solução viria posteriormente com a venda de títulos e de compromissos de recompra que empurravam as taxas de juro do mercado para cima e em direção à taxa de redesconto (ou "bank rate").
} 
Até então, não fora apresentada nenhuma teoria sobre as relações entre as políticas monetárias dos Bancos Centrais e as variações agregadas. Os governos não sentiam as pressões advindas daqueles que sofriam com as conseqüências das políticas monetárias restritivas; a população em geral não tinha poderes suficientes para interferir na condução das mesmas ${ }^{27}$. Os riscos cambiais eram, portanto, mínimos. Como não havia desconfiança quanto à paridade (ao menos no longo prazo), os movimentos de capitais eram benéficos para a manutenção do regime (Friedman 1968). Quando as reservas se reduziam e o câmbio desvalorizava, havia influxos na esperança de que as autoridades valorizassem a moeda doméstica, o que ainda proporcionaria ganhos de capital. No curto prazo, os movimentos de capitais tinham efeitos estabilizadores em razão da credibilidade que as autoridades monetárias detinham no longo prazo. Neste período, os movimentos desestabilizadores eram ainda de parca relevância quando comparados aos atuais.

Com o intuito de amenizar as flutuações do produto, o Banco da Inglaterra passou, em meados da década de 1870, a coordenar a formação da taxa de juros do mercado. Com o advento do padrão-ouro no âmbito internacional, a nação líder tomaria o leme da coordenação monetária. A taxa de redesconto da Inglaterra, que assumia um papel cada vez mais ativo no sistema econômico, serviria de baliza para as taxas dos outros países, harmonizando as condições de crédito mundial. Ademais, havia também certa cooperação: todos os países não podiam adotar as mesmas práticas caso algum deles estivessem em crise financeira. A harmonia esta que poderia ser destruída caso as ações fossem baseadas em um comportamento "olho por olho", onde as dificuldades financeiras por parte de certo Banco Central exigiam que os outros Bancos Centrais o apoiassem com influxos de ouro - assim como ocorreu em 1890 com o banco inglês Baring. Existia, assim, uma solidariedade necessária para a manutenção do padrão-ouro caso sobreviesse uma crise. Entretanto, se um país não tivesse um emprestador de última instância, uma fuga de ouro e de reservas cambiais levava a uma queda nos meios de pagamento. A ausência de um Banco Central ou a ausência de mercados de bônus e descontos impedia que houvesse uma esterilização das saídas de ouro doméstico. Para a Inglaterra, sua hegemonia econômica lhe fornecia a devida proteção

${ }^{27}$ Eichengreen $(2000$, p.58) ainda adiciona que a flexibilidade de salários e preços significava que um choque negativo no balanço de pagamentos poderia ser acomodado por uma redução nos preços e custos, e não por um aumento no desemprego. O que reduzia a pressão sobre as autoridades para que se preocupassem com o desemprego. 
em seu balanço de pagamentos e lhe permitia que a libra fosse usada como base do sistema financeiro internacional. Os volumosos empréstimos concedidos e as exportações de bens de capital por parte da ilha inglesa mantinham seu saldo externo e sua taxa de câmbio estabilizados. Para os países centrais, a expansão comercial era o que permitia o correto funcionamento de ajuste do padrão-ouro.

\subsection{Teorias Monetárias na Primeira Metade do Século XIX}

\subsubsection{Hume, Ricardo e A Teoria Quantitativa da Moeda}

Formulada originalmente por Bodin em 1568, a Teoria Quantitativa da Moeda (TQM) tinha como causa de sua existência teórica as severas oscilações no nível geral de preços do século XVI. Mas, colocado em melhores palavras, esta "teoria" deve ser entendida com um teorema, já que não é uma teoria completa sobre o dinheiro, mas sim uma proposição sobre seu valor-de-troca. Ela assegurava que um aumento na produção de ouro - ceteris paribus e assumindo que todas as mercadorias são vendidas e que todos gastam suas rendas com tais mercadorias - faria com que seu valor diminuísse ou que, identicamente, todos os preços cotados em ouro subissem. Neste caso, postulava-se que a subida dos preços seria exatamente proporcional ao aumento na oferta do metal precioso - o que mais tarde viria a ser denominado "teorema da proporcionalidade" 28 por duas razões: pelo próprio aumento do lastro e pela cunhagem de novas moedas metálicas. Ou seja, é a cunhagem de novas moedas que imediatamente, tomando como constante o poder de compra do estoque monetário total, deprecia o valor-de-troca do dinheiro. A quantidade de mercadorias é a mesma, mas agora para uma quantidade maior de moedas. Assim, o novo ouro adicionado cumpre duas tarefas: é novo ouro como mercadoria adicional, e é novo ouro como dinheiro adicional. O teorema então nos mostra que: (i) a função monetária afeta o valor da mercadoria escolhida para ser dinheiro, fonte logicamente distinta, embora não independente, do valor-de-troca do dinheiro; (ii) o mecanismo que determina o valor do dinheiro em circulação é diferente do mecanismo que determina o valor de qualquer outra mercadoria. Assumindo

\footnotetext{
${ }^{28}$ A TQM estrita, assim como a definiremos a seguir, trabalha com o teorema da proporcionalidade: no longo prazo todas as variações no estoque monetário se refletem integralmente no nível de preços $(\Delta \mathrm{M}=$ $\Delta \mathrm{P}$ ), deixando os preços relativos, a taxa de juros e o produto inalterados. Portanto, no longo prazo a moeda é neutra, isto é, no longo prazo a curva de Philips é vertical e a política monetária é ineficaz assim como defendido pelos novos-clássicos.
} 
monometalismo perfeito, fica claro que o ouro tem dois mecanismos, em decorrência de sua dupla constituição como mercadoria e como dinheiro, e que ambos têm de fornecer a mesma quantidade de valor. E é justamente esta característica deste teorema que permite que ele seja aplicado ao caso do papel-moeda sem mais pressuposições (Schumpeter 1955, p.313), já que o papel-moeda tem a vantagem de não apresentar esta ambigüidade de ser uma mercadoria. Quando não há uma mercadoria que opera como dinheiro, como o ouro, o problema do valor-de-troca do dinheiro fica esclarecido: o teorema trata essencialmente o dinheiro não como mercadoria, mas sim como um "ticket" ("voucher") para comprar coisas ${ }^{29}$.

Nos escritos de Petty, Locke e Cantillon, o problema a ser enfrentado era de ordem prática: qual a quantidade de moeda que um dado país necessita, a um dado nível de preços? Para Hume, no século XVIII, tal questão não fazia sentido do ponto de vista lógico, já que em um país isolado, qualquer quantidade será suficiente e, para os países como um todo, o metalismo prático asseguraria que cada país tivesse a quantidade relativa a sua participação no comércio mundial. Mas para os autores do século XVI e XVII, excetuando Cantillon, esta questão prática era necessária para combater $\mathrm{o}$ princípio mercantilista de estímulo às importações de metais preciosos. Ainda assim, a posição metalista precisava ser qualificada quando tinha a figura do crédito bancário à sua frente. O lastro em ouro forçava uma divisão teórica entre o dinheiro de fato e os direitos e instrumentos sobre dinheiro. Segundo Cantillon, a emissão de notas bancárias em excesso sobre as reservas não é entendida como uma expansão dos meios-depagamento, não é entendida como criação de dinheiro, mas sim como simples aumento da velocidade do meio-circulante existente. O crédito é, assim, definido como um meio mais eficiente de se usar dinheiro, e o banqueiro é assimilado como mero intermediário para organizar as demandas e ofertas de empréstimos. Sua atuação aumenta a velocidade e a eficiência do sistema e pressiona a taxa de juros para baixo. Crédito é aqui definido como uma forma especial de dinheiro. Cantillon, assim como Galiani e Turgot, acreditava que um banco somente emprestava o que estivesse em sua posse e que não estivesse sendo utilizado por seus correntistas. Não enxergavam tais autores,

\footnotetext{
${ }^{29}$ Schumpeter (1955, p.315-316) prefere explicar a Teoria Quantitativa pelas suas formulações originais que apareceram no séculos XVI e XVII por acreditar que as formulações posteriores e mais modernas somente adicionaram mistificações e ambigüidades.
} 
portanto, que o que o banco faz com o dinheiro não pode ser feito com nenhuma outra mercadoria, já que o direito ao dinheiro funciona como dinheiro de fato.

Para Hume, que podemos considerar como o proponente da "TQM pura", nem o dinheiro e nem as mercadorias possuem valor intrínseco e, portanto, não existe qualquer ponto de referência para o valor-de-troca do dinheiro - ao contrário do que afirmarão Ricardo e Marx. Neste caso a oferta de moeda pode variar independentemente do produto, ou seja, a oferta de moeda (ouro) é exógena. Em termos bem sucintos, o valorde-troca do dinheiro-mercadoria é regulado por uma TQM mundial segundo o seu price-level-specie-flow mecanism (Lapavitsas 2000, p.641).

Não obstante, falar em teoria quantitativa da moeda demanda maiores qualificações. Atribuir "importância" para o mecanismo de oferta e demanda na determinação do valor do dinheiro pouco significa em termos teóricos. Qual é a extensão de tal "importância"? Por exemplo: quando aumenta a oferta monetária, o decréscimo no poder de compra do dinheiro ocorre em que grau? A relação é proporcional?

Hilferding (1981, p.55-56) ainda nos lembra que é necessário diferenciar a validade da TQM dentro de dois regimes monetários no século XIX:

(a) Free coinage: neste regime o dinheiro entre e sai da circulação de acordo com a demanda prevalecente por ele e, caso haja um excesso, o excedente é acumulado nos bancos como reserva de valor (tesouro). A TQM não tem poder explicativo aqui. E tampouco há possibilidade de inflação;

(b) Suspendend coinage: neste regime toda a quantidade de dinheiro deve circular, independentemente do volume emitido. Neste caso o valor do dinheiro deriva do valor das mercadorias em circulação. Aqui a TQM opera bem.

Com vistas a evitar tais confusões, vamos definir o que é uma "teoria quantitativa estrita”, seguindo Schumpeter (1955, p.703) e Blaug (1995, p.29):

(i) A quantidade de moeda varia independentemente do nível de preços e do volume de transações, isto é, $\Delta \mathrm{M}$ é exógeno; 
(ii) A velocidade da moeda é um dado institucional que varia muito pouco, independente do nível de preços e do volume de transações; isto é, a demanda por saldos nominais é estável;

(iii) A demanda por moeda é estável e independente da oferta de moeda.

(iv) $\mathrm{O}$ volume de transações (ou o nível do produto) - a depender se usamos a versão de Fisher ou a de Cambridge - é independente da quantidade de moeda e do nível de preços; somente por acaso podem mover-se conjuntamente. O nível do produto é determinado por fatores reais (como dotações, preferências e tecnologia);

(v) Variações na quantidade de moeda, se não absorvidas por variações no produto da mesma direção, agem mecanicamente sobre todos os preços, independentemente de como esta diferença na quantidade de moeda é usada e qual setor da economia ela primeiramente afeta.

A qual, segundo Schumpeter, somente foi seguida por Ricardo, Wheatley, James Mill e McCulloch. Contudo, o que o conceito de "moeda" ou "dinheiro" compreende permanece obscuro. Estariam aí incluídas somente as moedas metálicas, depósitos e as notas conversíveis? E as notas inconversíveis em ouro, são consideradas como moeda? Como veremos, o problema com esta teoria, todavia, não reside no fato de as notas bancárias serem lastreadas ou não em ouro, mas sim na presença do crédito. J. S. Mill atestava que a introdução da figura do crédito faz com que os preços não respondam às variações na quantidade de moeda como prevê a teoria quantitativa:

"Quando entrar em jogo o crédito - diferente do dinheiro vivo - como instrumento de compra, veremos mais adiante que a relação entre preços e o montante do meio circulante é muito menos direta e íntima, e que o tipo de relação existente no caso do crédito já não comporta uma forma de expressão tão simples" (Mill 1983, p.55)

A resposta de Schumpeter (1955, p.705) sobre as conclusões de Mill (1983, p.69-92), de que o volume de crédito impacta tanto quanto o volume de dinheiro sobre os preços, aponta para o fato de que na verdade Mill não trabalha com o conceito de dinheiro, 
como parece à primeira vista, mas sim com o conceito de gasto ${ }^{30}$; que foi a mesma opção teórica adotada por Tooke em seu Inquiry into the Currency Principle de $1844^{31}$. Tornar a quantidade de moeda uma variável que indica o que de fato está sendo gasto é análogo a tomar a quantidade de moeda como um dado e tornar sua velocidade uma variável endógena, sujeita a comportamentos cíclicos. O que acaba por mostrar os dois componentes que são incluídos sob o rótulo de "velocidade": a "velocidade" dos gastos e a "velocidade" dos pagamentos. Arnon (1984b) afirma o mesmo ponto: a teoria de Tooke era uma teoria dos preços através de uma teoria da renda, dos gastos, para a qual os preços são determinados pela soma de dinheiro que compõe a renda dos consumidores; cujas conclusões eram as de que as flutuações na oferta de notas bancárias convertíveis somente representavam mudanças na composição da demanda, enquanto que flutuações na oferta de dinheiro inconversível representavam de fato mudanças no nível da demanda.

Para Ricardo, o dinheiro e mercadoria têm valores intrínsecos, dados a partir do trabalho incorporado e, portanto, existe um ponto de referência para o valor-de-troca do dinheiro. Se o produto cresce, coeteris paribus, o valor-de-troca do dinheiro também cresce, fazendo os preços caírem (dado que a oferta monetária e a velocidade do dinheiro não se alteram), já que há mais mercadorias para a mesma quantidade de moeda. Assim, o valor de dinheiro não depende somente da sua quantidade, mas sim da sua quantidade relativamente aos pagamentos que deve realizar. $\mathrm{O}$ aumento no valor-de-troca do dinheiro, sem que se alterem os valores intrínsecos do ouro e das mercadorias, significa que os possuidores nacionais e internacionais do bullion de ouro podem se envolver em arbitragem lucrativa. Eles põem ouro em circulação aproveitando da melhor relação do ouro com as mercadorias. Se o valor-de-troca das moedas de ouro cai por conta de uma queda no produto, o que eleva o nível de preços, os detentores dessas moedas em ouro podem lucrar derretendo e exportando-as como bullion. Com isto teremos queda na

\footnotetext{
30 '“...] purchases 'on credit' - that is, by means of credit instruments of one kind or another - influence prices as much as do purchases for money, we discover that in his [Mill's] analytic schema it is not all the quantity of money per se which acts upon 'general prices' but simply expenditure, and that this expenditure is not closely, let alone uniquely, related to the quantity of coin or paper money. [...] J. S. Mill's conceptual arrangement achieved the same end that others achieved by making velocity an economic variable" (Schumpeter 1955, p.705).

${ }^{31}$ Contudo, não faltaram argumentos contra tal empreitada de uma teoria monetária a partir dos gastos. Afinal de contas, estes gastos que pretendem explicar os preços também dependem deles; há uma forte causalidade reversa. E, ainda mais, o que ocorreria se interpretássemos os gastos como quantidade de moeda vezes sua velocidade?
} 
oferta monetária, fazendo a economia retornar ao equilíbrio entre produto e a devida oferta de dinheiro. Ou seja, variações quantitativas no produto ou na oferta monetária, coeteris paribus, alteram o valor-de-troca do dinheiro e põem em marcha um processo de arbitragem baseado nos valores intrínsecos do dinheiro e das mercadorias, que permanecem inalterados. A arbitragem continua enquanto a relação entre quantidades e valores permanecer incompatível, sendo que a quantidade de dinheiro se ajusta para eliminar o distúrbio original no seu valor-de-troca: o valor intrínseco do ouro opera como uma âncora para o seu valor-de-troca, dado que a oferta monetária pode se ajustar livremente. Porém, todo este mecanismo depende de que o dinheiro entre e saia livremente da circulação. Se isto não ocorrer sem atritos como se supões, o raciocínio não vale. Se o oferta monetária for determinada arbitrariamente, o valor-de-troca do dinheiro tornar-se-á inteiramente determinado pelas quantidades de dinheiro e mercadorias em circulação, independentemente do valor intrínseco do ouro. Isto é, se a quantidade de dinheiro circulante for fixada exogenamente, o valor intrínseco do ouro não mais serve como âncora ao valor-de-troca do dinheiro. O que valida a TQM (Lapavitsas 2000, p.641-643).

Em termos sintéticos, o esquema de Ricardo era o seguinte: caso haja incompatibilidade entre o valor-de-troca e o valor intrínseco do ouro, a arbitragem dos agentes espontaneamente regula a quantidade de dinheiro em circulação, mas se esta arbitragem é impossibilitada, o valor-de-troca do dinheiro será determinado puramente pelas quantidades de dinheiro e mercadorias em circulação, independentemente do valor intrínseco do ouro. Assim, a TQM vale se o oferta monetária for exógena (isto é, se houver impedimentos à arbitragem). Se o jogo do mercado for livre, a oferta monetária torna-se endógena e a TQM não mais funciona.

Para Ricardo, a velocidade da alteração da produção do ouro, dada uma variação na produtividade do setor ourífero, depende (em termos reativos) do estoque já existente de ouro mundial e das exportações desse novo ouro. Vejamos melhor, então, como opera o mecanismo ricardiano e como ele se inverte. Se há mais demanda por ouro, o maior preço dele será expresso como um menor preço de todas as outras mercadorias, aumentando a taxa de lucro na produção de ouro, que será estimulada até que a nova oferta cubra a nova demanda por dinheiro. Assim, o preço do ouro cai e o preço das mercadorias sobem, fazendo o preço do ouro voltar à sua igualdade com seu valor em 
trabalho. A taxa de lucro excedente zera e o equilíbrio de longo prazo é restaurado. Isto é, o valor do ouro em trabalho opera como um centro atrator no longo prazo para o preço de mercado do curto prazo. Assim, a causação é claramente de $\Delta \mathrm{P} \rightarrow \Delta \mathrm{M}$ (assim como para Marx). $\mathrm{O}$ ajuste acima funciona corretamente se o fluxo de ouro domina o estoque mundial de ouro existente. Porém, se o fluxo de ouro novo for relativamente pequeno, então o estoque domina o fluxo, o mecanismo de ajuste não funciona e a determinação é revertida: não é mais a produção de ouro que regula o seu valor, mas sim é o valor que regula sua produção (Likitkijsomboon 2005, p.170 e Laidler apud Blaug 1995b, p.34). No caso geral pode-se assumir que o estoque mundial de ouro é bem superior ao fluxo de novo ouro e, portanto, podemos ignorar tal fluxo. Logo, o valor-trabalho do ouro deixa de ser relevante e o valor do ouro passa a ser determinado por variações de curto prazo na sua distribuição entre os países. Se assumirmos que a demanda por ouro é estável (logo V é estável), então o valor do ouro depende de sua oferta num país em específico e da distribuição do ouro entre usos monetários e não-monetários. Em uma economia aberta, $\Delta \mathrm{M}$ domésticos podem decorrer de oscilações na distribuição internacional do estoque de metal expressas através de desequilíbrios comerciais externos, que são dependentes (segundo o specieflow mechanism) dos desequilíbrios nos preços relativos internacionais. Uma economia aberta está em equilíbrio quando há um estoque monetário justo, tal que os preços domésticos vis-à-vis preços internacionais não levem a trocas entre países; a taxa cambial é a de equilíbrio e não há trocas internacionais de ouro.

Como veremos, Marx vai criticar Ricardo por não ter incorporado em seu raciocínio o papel fundamental do entesouramento como garantidor da ancoragem do valor-de-troca do dinheiro no valor intrínseco do ouro. Isso porque Ricardo se concentrou no dinheiro enquanto moeda, enquanto meio, e não enquanto fim.

Não obstante, um comentário é inevitável. Quando operava o padrão-ouro tradicional, entre 1870 e 1914, a TQM apresentava dificuldades em explicar o cenário econômico que se delineava, ainda mais quando apartada de uma teoria dos ciclos econômicos, cujo melhor exemplo eram os casos de crises nos quais a defesa das reservas de ouro era cumprida a qualquer custo, o que ensejava grandes e bruscas variações nos juros e nos preços. A existência do lastro em ouro causava ajustes muitas vezes violentos no 
sistema de crédito via variações nos empréstimos e no nível do produto nacional. Sobre estes eventos a TQM, naturalmente, se calava ${ }^{32}$.

\subsubsection{Teorias Monetárias na Inglaterra}

O primeiro período do século XIX a ser investigado se estende do ano de 1797 a 1844. A data inicial, ainda no século XVIII, foi o ano da aprovação do Restriction Act pelo Parlamento britânico, que permitiu ao Banco da Inglaterra não converter suas notas bancárias ou outros direitos financeiros em ouro. Foi decretado, assim, o curso forçado de suas notas bancárias inconversíveis. Com a declaração de guerra contra a França revolucionária em 1793, o Governo britânico foi forçado a aumentar a oferta de notas bancárias ao ser pressionado pelos gastos militares. Contudo, a maior impressão de notas conjugada à então existente conversibilidade em ouro das mesmas tinha dois efeitos sobre o Banco da Inglaterra: tendia a reduzir as reservas em ouro e tendia a reduzir o valor das notas. Para se ter uma idéia, ao final da guerra, em 1814, o valor de face das notas emitidas chegava a $£ 28,4$ milhões sobre uma reserva de apenas $£ 2,2$ milhões em barras de ouro, levando a inevitável depreciação da libra em 30\%. Nesse período de vigência das notas bancárias inconversíveis permitida pelo Bank Restriction Act de 1797 a 1819, as notas ainda permaneceram dependentes do ouro, ainda que somente em termos nominais (já que as reservas não garantiam sua conversibilidade). Em clara demonstração do conflito entre os valores de face e as reais reservas metálicas do Banco, as notas foram depreciadas mesmo sendo inconversíveis ${ }^{33}$. A TQM ganha muita proeminência com a suspensão da conversibilidade da libra e das notas bancárias em 1797 na Inglaterra, que introduziu no debate questões como dinheiro fiduciário, câmbio flutuante e regimes monetários com oferta monetária exógena (Blaug 1995b, p.30), afinal neste ínterim a causalidade é claramente do estoque de moeda para os preços.

\footnotetext{
32 Ademais, na análise de Marx, a inflação causada por aumentos exógenos na oferta monetária simplesmente não existe. Qual é, então, o efeito dos movimentos internacionais de ouro sobre o dinheiro circulante e sobre os preços? Pelo pouco que ele escreve vemos que fluxos internacionais de ouro alteram as reservas bancárias, câmbio e juros, sem impactos sobre a oferta monetária, investimento ou preços (Likitkijsomboon 2005, p.164).

${ }^{33}$ Mais sobre isso, ver Grundrisse (Marx 1973, p.130-132).
} 
O ponto de chegada desta primeira fase se daria através de dois acontecimentos: um prático - o Bank Act de 1844 -, e um teórico - a publicação dos Principles of Political Economy de J. S. Mill em 1848, seguidos posteriormente pela inflação do ouro da década de 1850. As investigações teóricas acerca do sistema monetário das quatro primeiras décadas do século XIX - entre as quais se destacam as de Ricardo, Tooke, Torrens, Malthus, Senior, J. S. Mill e Thornton - seriam fortemente influenciadas por tais políticas inglesas. Os gastos governamentais da Inglaterra, ainda que parcialmente cobertos pelos aumentos da arrecadação tributária e ainda que respaldados pelos empréstimos advindos do Banco (que pouco podia fazer contra as necessidades de adiantamentos do governo), cresciam de maneira exponencial.

A controvérsia que se seguiu à inflação de 1793-1815 mostrou sua faceta no debate entre, de um lado, aqueles que a diagnosticavam como resultante das políticas do Banco da Inglaterra e, de outro, aqueles que não diagnosticavam nenhum processo de escala dos preços ou que o justificavam por fatores não somente concernentes ao Banco. Os do primeiro grupo, identificados pela publicação do Bullion Report de 1810, eram denominados de Bullionistas. Os do segundo grupos, em oposição aos primeiros, foram denominados de Anti-Bullionistas - mesmo que na prática o Bullion Report fosse composto por diferentes perspectivas. Debate este que apontou por mais de cem anos a controvérsia que circunscreveria as teorias monetárias posteriores ${ }^{34}$.

Embora não legalmente, a Inglaterra manteve efetivamente um padrão-ouro até sua suspensão em 1797. A adoção legal do padrão viria somente em 1819, com a retomada dos níveis de conversão prevalecentes em 1793 através do Peel's Resumption Act de 1819-1821. O cenário econômico adjacente a 1819 compreendia uma forte recessão evidenciada pela intensa queda do nível geral de preços - algo em torno de $30 \%$ em 5 anos -, queda nas taxas de lucro e nas taxas de juros, aumento no desemprego e instabilidade. Fatores estes que compunham os estágios finais do paradigma tecnológico então prevalecente e os estágios iniciais da nova estrutura de oferta que se consolidava. A estabilidade do novo padrão industrial somente viria na década 1840. Para o período

\footnotetext{
${ }^{34}$ Segundo Schumpeter (1955, p.692), o relatório de 1919 do Cunlife Committee, que recomendou a volta da Inglaterra ao padrão-ouro pré-1914, tem pouca, se alguma, originalidade teórica quando comparado ao Bullion Report de 1810.
} 
agora analisado, assim sendo, não se deve jamais perder de vista estes determinantes cíclicos.

\subsubsection{Bullionistas e Anti-Bullionistas}

O relatório do Bullion Comittee de 1810 é a decorrência prática e teórica dos ensinamentos de David Ricardo, e postulava ser o dinheiro um simples símbolo de valor. Ricardo começa sua exposição da forma dinheiro a partir da sua teoria do valortrabalho. Ele determina em primeiro lugar o valor do ouro como o de qualquer mercadoria, pelo tempo de trabalho objetivado nele. Assim, tendo o valor do dinheiro como dado, Ricardo determina a quantidade dos meios de circulação pelos preços das mercadorias, e o dinheiro, como símbolo de valor, é representante de uma quantidade determinada de ouro - ao contrário de Hume, que achava que o ouro era representante sem valor das mercadorias. Se para Ricardo o trabalho fornece valor às mercadorias, Hume colocava em circulação somente valores-de-uso e não mercadorias com determinado valor.

Todavia, Ricardo "interrompe bruscamente o curso regular da sua exposição para adotar a tese contrária" (Marx 1982, p.122), a da teoria quantitativa da moeda. Ricardo, ao tratar do dinheiro, oscila constantemente entre a teoria do valor-trabalho e a teoria quantitativa da moeda, ao afirmar que a oferta de papel-moeda também determina o nível de preços. Para fazer isso, Ricardo deveria provar que os preços e o valor do ouro dependem da oferta de ouro. Mas sua demonstração consiste justamente em tomar como dado o que deveria derivar: ele já pressupõe de partida que toda a oferta de ouro é necessariamente meio-de-circulação (moeda, símbolo de valor), seja qual for a soma dos valores das mercadorias que circulam. Ricardo abstrai de todas as outras funções que o dinheiro desempenha além da sua função como moeda, restringindo-se ao fenômeno da desvalorização dos símbolos de valor ao elevar-se sua quantidade. Em outras palavras, ele trata o dinheiro somente como moeda, e não como dinheiro. Para Ricardo, dinheiro nada mais é do que moeda e, assim, toda a quantidade de ouro existente em certo país deve circular e, sendo seu próprio símbolo de valor, varia acima ou abaixo do seu valor intrínseco. Isto é, entende-se que algo possa ser símbolo de si mesmo e, dessa forma, chega-se à conclusão de que o valor do ouro pode subir ou 
baixar em torno do seu próprio valor. Resumindo o raciocínio de Ricardo para facilitar nossa exposição, teríamos:

(a) Qual a origem de uma queda geral nos preços? Da alta do valor relativo do dinheiro (e vice-versa).

(b) A subida dos preços resulta da queda de valor do dinheiro, e a queda do valor do dinheiro advém de um aumento em sua oferta, que ultrapassa o nível determinado pelo seu próprio valor imanente e pelos valores imanentes das mercadorias. Logo, as oscilações de preços são decorrentes das variações na oferta de dinheiro, como afirma a Teoria Quantitativa da Moeda.

(c) Ricardo enuncia o problema sem explicá-lo, permanecendo em uma relação tautológica. Mas ele dá uma aparência de relação causal a essa relação tautológica.

(d) Qual o problema? Ricardo pressupõe que o valor "imanente" do dinheiro, dado a partir de seus custos de produção, se mantém inalterado.

(e) Qual a decorrência lógica disto? Se a oferta de dinheiro estiver atrelada à oferta de ouro, os desequilíbrios se compensam através de um mecanismo de ajuste automático (como acontecia com o modelo de Hume).

(f) Qual o problema? Ricardo transpõe esse raciocínio para o mercado de crédito. Portanto, as crises de crédito são interpretadas como crises de dinheiro. Confunde-se a circulação simples com o sistema de crédito desenvolvido. Ricardo aplica as leis que regulam a oferta de dinheiro à regulação da oferta de crédito, apesar de ambas dizerem respeito a níveis de abstração completamente distintos ${ }^{35}$.

(g) O crédito não é regulado pelas leis da circulação metálica, mas Ricardo quer que na prática o sejam; ele quer que o mecanismo auto-regulador do dinheiro metálico, via importações e exportações de ouro, seja aplicado às notas bancárias. Desse modo, a emissão de notas bancárias (crédito) deve se regular pelas importações e exportações de ouro, ou pela cotação do câmbio.

(h) Ricardo pressupõe erroneamente que todo o ouro é somente moeda e que todo afluxo de ouro faz aumentar a oferta de dinheiro e faz subirem os preços. Para

\footnotetext{
35 "Ricardo, como seus predecessores, confunde a circulação das notas bancárias, ou da moeda creditícia, com a circulação dos simples sinais de valor” (Marx 1982, p.121). “[...] a massa desse capital monetário emprestável é diferente e independente da massa de dinheiro em circulação” (Marx 1984b, p.36-37).
} 
ele, dinheiro só opera como meio-de-circulação. Ele pressupõe teoricamente que todo o ouro circula como moeda e quer que na prática isso ocorra. Ricardo quer ver circular tanta moeda quanto exista de ouro. Ou seja, Ricardo não analisa o dinheiro enquanto tesouro, que - segundo Marx - funciona como mecanismo para regular o ouro em circulação conforme as necessidades da produção.

A teoria ricardiana do dinheiro e do crédito, em decorrência do sucesso teórico e prático logrado por seu autor, forneceu as bases científicas diretamente à Currency School e ao Bank Act de 1844. Mas, como veremos a seguir, esta legislação foi posta de lado na primeira crise comercial que acometeu a Inglaterra. Neste caso, a própria prática se encarregou de mostrar as deficiências da teoria. Neste sentido, o Bank Act nada mais foi do que um erro lógico decorrente de uma apreensão do que era o dinheiro e o crédito.

Tooke, a partir da análise histórica dos preços das mercadorias entre 1793 e 1856 percebeu as falhas no raciocínio ricardiano. Segundo Tooke, a correlação direta entre preços e oferta de meio-de-circulação não se verifica na prática. Para ele, a contração dos meios-de-circulação, dado o valor do ouro, é o efeito e não a causa das variações nos preços. Posteriormente, em seu Inquiry into the Currency Principle de 1844, após ter revisto algumas de suas posições teóricas, resume suas conclusões, entre as quais se destaca a de que os preços não são conseqüências do meio-circulante, mas sim o contrário, isto é, que o meio-circulante é determinado pelos preços. Seus achados teóricos, que se aproximam em muito dos de Marx, apontavam exatamente para o fato de o dinheiro não se enquadrar somente na determinação de meio-de-circulação.

A alta do "preço" do ouro acima do seu valor (determinado pelo tempo de trabalho objetivado) provocaria um aumento de produção do ouro até que esse aumento da oferta reduzisse seu preço ao atingir a correta quantia dada pelo seu valor intrínseco. Tais oscilações resolveriam a contradição entre o valor metálico do ouro e seu valor como meio-de-circulação. Haveria um nível correto para a massa de ouro circulante. Se o próprio ouro pode ser símbolo de valor de um valor metálico diferente do seu próprio, postulava Ricardo que as notas bancárias conversíveis compartilhavam da mesma determinação. Ainda que conversíveis (que seu valor real corresponda ao seu valor nominal), a massa total de dinheiro e de notas circulantes pode ver seu preço variar 
conforme sua quantidade disponível. Assim sendo, em contraposição ao o papel-moeda conversível, o papel-moeda inconversível tem a vantagem de desvalorizar-se de dois modos: pode oscilar em relação ao valor do ouro de acordo com sua emissão, e pode oscilar quando varia o valor intrínseco do ouro. Portanto, com o papel-moeda inconversível, há uma possível desvalorização do papel e do ouro em conjunto. Esse foi o princípio posteriormente defendido por Lord Overstone e por Robert Peel, e que se consubstanciou na reforma bancária de 1844 .

Entre aqueles que defendiam teoricamente a conversibilidade das notas, a questão prática de como tal conversibilidade seria garantida os dividia em duas opiniões: se seria pelos próprios mecanismos do Banco da Inglaterra, ou se seria pela imposição de uma lei específica. Entre os do primeiro grupo reinava a idéia de que empréstimos do Banco amparados pelas letras de câmbio (bills of exchange) forneciam um mecanismo suficiente que garantia o refluxo das notas e a conversibilidade das mesmas ao menos na média - este eram os adeptos da Lei do Refluxo das notas bancárias, lei que foi também esposada por Marx. Ao contrário destes, a posição dos Bullionistas estritos era a forte defesa da conversibilidade pela força da lei. Para esses, a necessidade da conversibilidade estrita era dada pela própria denominação das notas em libras, e também forneceria um impedimento contra sobre-emissões (alegando que os argumentos contrários representavam os anseios de pseudo-defensores da inconversibilidade). Isto é, para os Bullionistas os mecanismos de mercado por si só não eram condição suficiente para a estabilidade do sistema monetário; a força da lei, neste caso, deveria imperar. No outro extremo em relação aos Bullionistas estavam os anti-Bullionistas e, embora defendessem a manutenção das denominações das notas em libras-peso em ouro ${ }^{36}$, eram advogados da inconversibilidade. $O$ próprio mercado se encarregaria de fazer retornar ao seu emissor quaisquer notas bancárias emitidas em excesso em relação às “necessidades da circulação".

O diagnóstico dos Bullionistas acerca da inflação do pós-guerra inglesa parecia negligenciar os componentes cíclicos dos paradigmas tecnológicos que se confrontavam

\footnotetext{
${ }^{36}$ Sobre isso, ver mais em Marx (1973, p.131-133). Para todos os efeitos práticos, a real conversibilidade ou não das notas não se deve buscar no volume de reservas em ouro, senão em sua conversão de fato por ouro no mercado pela mesma quantia como exposta em seu valor de face.
} 
na época. Para eles, a queda no nível de preços que se experimentou durante os anos 1820 decorria do Resumption Act de 1819, e acusavam primordialmente o Banco da Inglaterra de um mau gerenciamento da volta ao padrão-ouro vigente no pré-guerra e também por este ter induzido uma depressão mundial com o aumento do valor do ouro. Deixavam, portanto, aspectos não-monetários, como os referentes à “criação destruidora" fora de suas análises. Os Bullionistas, tendo Thornton como um de seus principais expoentes, desejavam a volta imediata ao pagamento em ouro pelo Banco da Inglaterra. Afirmavam que o prêmio sobre o bullion era uma prova da desvalorização das notas bancárias. $\mathrm{O}$ aumento deste prêmio, a apreciação cambial e a inflação teriam sido menores, sustentam eles, se a circulação de notas tivesse se restringido às notas conversíveis, isto é, se a oferta monetária tivesse sido menor e compatível com as reservas em metais preciosos. É esta característica que aproxima os Bullionistas dos Metalistas - ainda que Thornton não usasse a teoria quantitativa em seu sentido estrito.

Colocada em termos alternativos, a TQM de Ricardo parecia sintetizar dois elementos antinômicos: a teoria do valor-trabalho aplicada ao dinheiro-mercadoria e uma análise de oferta monetária exógena. Se Ricardo se afasta da TQM em suas premissas (de que o dinheiro tem valor próprio), ele se aproxima dela no desenvolvimento do raciocínio (ao estudar as variações exógenas na oferta de moeda). Marx percebeu esta oscilação de Ricardo ao dizer que este interrompe sua exposição lógica para adotar em seguida a tese contrária. Mas há um ponto importante nisto: a oscilação de Ricardo entre teses opostas não é fortuita, senão expressão da contradição entre forma e matéria do dinheiro. Ou seja, se a matéria ouro do dinheiro fazia com que Ricardo usasse a teoria do valor-trabalho para determinar o valor-de-troca do dinheiro, a essência formalista do mesmo fazia com que Ricardo também analisasse o dinheiro como pura forma através da TQM. Se ele vacila entre uma teoria e outra, é porque o seu objeto assim se mostra. A TQM de Ricardo é a manifestação teórica de uma contradição prática entre forma e matéria do dinheiro. $O$ desenvolvimento da tese ricardiana nega suas premissas justamente em decorrência do fato de o desenvolvimento da forma dinheiro também negar suas premissas ${ }^{37}$.

\footnotetext{
${ }^{37}$ No próximo capítulo mostraremos como o desenvolvimento da forma dinheiro nega sua gênese. Os resultados, para a dialética, mais do que decorrerem das premissas, as negam.
} 
Até Marx ficou preso nesta armadilha histórica, pois ainda que revelasse a forma pura como essência do dinheiro, ele mesmo ficou restrito ao padrão-ouro do século XIX. Portanto, se hoje o dinheiro é de fato forma pura efetiva, dinheiro inconversível, deve-se perguntar sobre a validade das análises de Marx e da TQM, e disto nos ocuparemos no capítulo a seguir. Marx parece ter resolvido este problema de Ricardo, mas não resolveu. Se Ricardo oscilou entre uma oferta monetária ora endógena ora exógena, Marx se aferra à endogeneidade através do mecanismo do entesouramento. Portanto, se Ricardo vacilou - porque o seu objeto vacilava -, Marx não vacilou porque se apegou à materialidade do dinheiro, ainda que o afirmasse essencialmente como pura forma. Quando pensado à luz do dinheiro inconversível atual, veremos que ambos Ricardo e Marx erraram. Ricardo errou porque confundiu moeda com dinheiro, e Marx porque se aferrou à tradição da Banking School. Os itens a seguir aprofundam esta discussão.

\subsubsection{Currency School e Banking School}

Em torno de 1800, o avanço conseguido pelo setor bancário inglês era invejável. Além do Banco da Inglaterra, o país contava com inúmeras casas bancárias privadas e com vários agentes de corretagem. Fora de Londres, indústrias e comerciantes eram financiados por bancos regionais e pelos bill brokers, formando um todo virtuoso e organicamente articulado. Tais bancos regionais, apesar de operarem também com depósitos, financiavam seus clientes via notas bancárias (como notas promissórias pagáveis em moedas ou em notas do Banco da Inglaterra) emitidas contra os descontos da notas comerciais (commercial bills). As reservas para estes casos não eram regidas por lei e foram descontinuadas com a Reforma Bancária de 1844. Para alguns teóricos da época, o mecanismo de emissão de notas bancárias a partir de notas comerciais era central para o sistema financeiro, sendo seus adeptos conhecidos como a Commercial Theory of Banking. Em certas localidades da Inglaterra, os comerciantes locais usavam letras cambiais (bills of exchange) para realizarem pagamentos. Isto é, os comerciantes, ao invés de operarem com meio-de-circulação de fato, operavam com letras que trocavam e endossavam entre si. Tais letras, em lugar de aumentar a demanda por liquidez, aumentavam de fato a oferta de liquidez (Schumpeter 1955, p.695). O Banco da Inglaterra, dentro desta rede orgânica, acabou por emergir como emprestador de última instância por excelência. 
Esta divisão entre duas "escolas", a Currency - representada aqui por Torrens e Overstone - e a Banking - representada por Tooke, Fullarton e Gilbart -, é menos rígida do que parece à primeira vista, dada a conhecida heterogeneidade entre membros de um mesmo grupo. Distinção esta dificultada ainda mais pelo fato de poucos destes autores terem explicitamente sistematizado suas idéias e por terem, em várias vezes, caricaturado os argumentos que procuravam combater. Como ficará evidente neste capítulo, ainda que não seja o nosso foco, a Banking School influenciou muito o que viria a ser a teoria keynesiana e posteriormente pós-keynesiana. A Currency School, por sua vez, influenciaria em muito o monetarismo das décadas de 1970 e 1980. Diz Blaug (1995a, p.3) que a Currency School rejeitava uma política discricionária ao demandar uma regra monetária através de uma reforma institucional que diminuísse os graus de arbitrariedade do Banco da Inglaterra. O Bank Act de 1844 deve assim ser interpretado como uma exigência desta escola pelo fim de políticas monetárias discricionárias, onde a nova regra de conversibilidade de notas bancárias em ouro operaria para proporcionar maior estabilidade ao sistema monetário e creditício ${ }^{38}$.

Os anseios da Banking School se concentravam nos seguintes argumentos: (i) dadas a condições do sistema monetário inglês e da liderança do Banco da Inglaterra, a conversibilidade das notas bancárias (redesconto das notas comerciais) seria condição suficiente para a estabilidade do sistema financeiro - esta era a Lei do Refluxo de Fullarton, para a qual o mercado se encarregaria de eliminar os excessos de crédito; (ii) em qualquer caso, não há razão para regular somente as notas bancárias, já que os depósitos poderiam acarretar os mesmos problemas. Dessa maneira, esta escola negava que o Banco da Inglaterra tivesse controle sobre o dinheiro criado pelos bancos privados. Usavam a doutrina dos Real Bills e a Lei do Refluxo para afirmar que a oferta monetária era de fato determinada pela demanda e endogenamente determinada pelas necessidades do comércio (Blaug 1995, p.33-34). Assim, qualquer tendência de sobreemissão de notas bancárias seria corrigida no processo de compensação inter-bancária

\footnotetext{
38 "[The Bank Act of 1844] was the first attempt by a capitalist systematically to regulate the supply of money in order to achieve greater economic stability. Contemporary monetarism, whose cornerstone is control of the supply of money, is the modern equivalent of the currency school" (Itoh e Lapavitsas 1999, p.xvi). E, por outro lado: "There is considerable similarity between the arguments of the banking school and the work of contemporary post-Keynesianism" (idem).
} 
via competição e via perdas de reservas. A negação da exogeneidade da oferta monetária era, portanto, um decorrência lógica.

Por outro lado, a Currency School afirmava que: (i) a conversibilidade de notas não poderia ser assegurada sem restrições específicas sobre sua emissão; (ii) as notas do Banco da Inglaterra deveriam ser entendidas como certificados de ouro (como simples representante em papel), e não como instrumentos de crédito (como os depósitos ou títulos comerciais). Para eles, as notas do Banco da Inglaterra não eram instrumentos de crédito, mas dinheiro de reserva. $\mathrm{O}$ objetivo era fazer com que a circulação de ouro e de notas ocorresse como se circulasse somente ouro, estando garantido que a quantidade de notas correspondesse exatamente à quantidade de ouro das reservas ${ }^{39}$. Estes autores entendiam, como fica claro nos escritos de Thornton, que a emissão de notas bancárias via redesconto de notas comerciais por si não restringia suficientemente a capacidade de sobre-emissão de notas e, assim sendo, o bom funcionamento do mercado demandava impeditivos adicionais sobre o dinheiro circulante. O desejo da Currency School, posteriormente consubstanciado no Peel's Act de 1844, era o de regular a emissão de notas a fim de deixar os negócios bancários com maior liberdade, pois despreocupados em relação a questões de conversibilidade. O Currency Principle, além de assentar-se sobre a TQM, entendia o estoque monetário como a soma de papel-moeda e das notas bancárias em circulação. Seus defensores queriam simular as leis da circulação metálica, objetivando uma circulação monetária estável através da cobertura total em ouro das notas bancárias, sendo sua emissão regulada pelas importações e exportações de ouro. O pressuposto teórico da reforma de 1844 partia da idéia de que Ricardo teria descoberto as leis da circulação puramente metálica, bastando agora, na prática, submeter a circulação do crédito ou das notas bancárias a essas leis. Notas bancárias são dinheiro? Para Ricardo e Overstone, elas, apesar de não serem crédito, eram sim dinheiro de fato - embora não o devessem ser (Schumpeter 1955, p.700). Havia, portanto, uma tendência em identificar as notas bancárias com papel-moeda: as notas bancárias se tornaram papéis que usurparam as tarefas do papel-moeda e que foram, portanto, concomitantemente identificadas como ouro ideal.

\footnotetext{
39 Schumpeter (1955, p.728) mostra que Torrens acreditava que o volume de crédito que os bancos podiam criar com seus empréstimos estava atrelado ao volume existente de moedas e notas, e que, portanto, a regulação da emissão de notas também regularia a criação destes depósitos.
} 
Entretanto, a "teoria" de que o valor relativo do dinheiro cai conforme aumenta o nível geral de preços - assim como expressaria Irving Fisher ${ }^{40}$ décadas mais tarde -, somente enuncia o problema, mas pouco serve para explicá-lo. Contudo, isto dá a aparência de explicação causal a uma simples tautologia. Como vimos, segundo Ricardo, uma queda no valor do dinheiro provém de sua quantidade excessiva em circulação, acima dos níveis determinados pelo valor do dinheiro e pelos valores das mercadorias em geral; e vice-versa. Desse modo, a explicação para a oscilação periódica dos preços se encontra na oscilação periódica da quantidade de dinheiro em circulação. Mas, como mostra Marx (1984b, Cap.34), isto não é empiricamente verificado; existem períodos em que os preços sobem mesmo com reduções na quantidade do meio-circulante. No caso de Ricardo, que trabalhara essas flutuações cíclicas em um sistema puramente metálico, o processo de ajuste se daria pelo balanço de pagamentos, via equilíbrio do saldo comercial e da taxa de câmbio. Contudo, o desenvolvimento do sistema de crédito traz em seu âmago as crises monetárias, período em que o mecanismo ricardiano de volta ao equilíbrio não se verifica. A explicação de Ricardo, assim como levada ao seu extremo pela Currency School e pelo Peel Act, não comportava a possibilidade de crises e nem contemplava um sistema creditício desenvolvido. Tanto para Ricardo quanto para Currency School, tudo se reduzia facilmente a uma circulação puramente metálica, na qual as crises não eram uma possibilidade se o sistema funcionasse devidamente ancorado pelas reservas de ouro ${ }^{41}$. Entretanto, é "evidente que a emissão de notas de banco não se regula exatamente segundo as leis da circulação metálica" (Marx 1984b, p.74). A circulação metálica se ajusta automaticamente pelo equilíbrio exigido no balanço de pagamentos e via exportações e importações de ouro que exige. Porém, por trás deste raciocínio está o pressuposto de que todo o ouro disponível para um país em um dado momento opera como meio-de-circulação, tendo impactos direta e totalmente sobre os níveis de preços domésticos. Esta é a essência da

\footnotetext{
${ }^{40} \mathrm{Na}$ formulação da exchange equation de Fisher (1922), ou formulação Newcomb-Fisher para a determinação do poder de compra do dinheiro, a equação MV=PT não é uma identidade, mas uma condição de equilíbrio. Nesta forma ela não diz que MV é o mesmo que PT ou vice-versa. O que ela diz é que, dados M, V e T, o sistema tende a determinar um certo $\mathrm{P}$ (o que é diferente de dizer que dadas tais variáveis, o sistema determina um certo $\mathrm{P}$ ). Contudo, neste caso, o problema teórico e prático está mais na conceituação das variáveis M, V e T. Sobre esta discussão teórica, que ao menos envolvia três posições (a de Fisher, a de Wicksell e a norte-americana), ver Schumpeter (1955, p.1095-1098).

${ }^{41}$ Um sistema assentado sobre um padrão-ouro irrestrito implicava, em geral, em taxas cambiais dentro dos "specie points" ou "golden points" e em uma conexão direta e quase automática entre o nível geral de preços domésticos e a taxa de juros.
} 
Reforma Bancária inglesa, cujo inevitável colapso teórico e prático se deu por conta de sua inadequada apreensão de um sistema bancário e creditício desenvolvido ${ }^{42}$.

No Volume II de O Capital, Marx parece deixar mais claro ainda o porquê de sua oposição ao crédito lastreado ao ouro. Diz Marx (2000, p.391) que ao desenvolver-se a função de meio-de-pagamento do dinheiro, "grande parte do processo social de produção e de trabalho se efetua sem qualquer intervenção de dinheiro real”. Assim sendo, seria possível manter a atual magnitude da produção sem sistema de crédito? "Evidentemente não. Ela ficaria limitada pelo volume da produção de metais preciosos". Portanto, a confusão entre as determinações de dinheiro e de crédito levou ao problema prático de querer restringir a produção ao volume de metais preciosos.

Mas caso os empréstimos bancários ultrapassassem os limites do "capital real", através das notas bancárias e da criação de depósitos, como se denominaria esta expansão “indevida"? Lorde Overstone (Schumpeter 1955, p.745-746) acreditava que o sistema financeiro passaria por uma mudança qualitativa ao superar suas próprias restrições de liquidez. Ele sabia que inadequações individualmente localizadas poderiam ser corrigidas pelas forças da competição, contudo, também acreditava que fosse possível que o majoramento da liquidez pudesse atingir níveis inadequados para o sistema bancário como um todo. Este seria então o ponto de ruptura. Além do capital "real", identificado como o estoque de poder de compra que os bancos absorvem pelas poupanças do público mais os influxos de ouro, Overstone acreditava - assim como Ricardo -, que esta soma excedente se enquadraria na categoria de capital "fictício". Contudo, a forma capital fictício fora desprezado por Ricardo como constituinte do mecanismo da formação de capital:

"97. State what in your Opinion is the Difference between that State of Things, in which a Stimulus is given by fictitious Capital arising from an Over-abundance of Paper in Circulation, and that which results from the regular Operation of real Capital employed in Production? [Ricardo:] I

\footnotetext{
42 "Os mercantilistas viam no saldo favorável em ouro ou prata da balança comercial a finalidade do comércio exterior. A seus adversários, entretanto, faltava inteiramente a compreensão das funções do dinheiro universal." (Marx 2002, p.171). As "tentativas do Governo inglês de apoiar-se nessa teoria (Lei Bancária de 1844) não tiveram nenhum sucesso e apenas confirmaram a falta de solidez científica dessa teoria e sua inutilidade para objetivos práticos" (Marx 1984a, p.318).
} 
believe that on this Subject I differ from most other People. I do not think that any Stimulus is given to Production by the Use of fictitious Capital, as it is called" (Ricardo 2005, p.445-446 - ênfases nossas)

“Ricardo ... kept on repeating ... that 'fictitious capital' cannot stimulate industry, that capital can only be created by saving and not by banking operations" (Schumpeter 1955, p.724 - ênfases nossas)

Ainda que David Ricardo admitisse que os bancos pudessem criar na prática um multiplicador sobre seus depósitos à vista, ele defendia que isto não deveria ocorrer. Se os bancos não se restringissem a emprestar o que de fato tinham para ser emprestado, o sistema monetário corria riscos de se tornar instável. Ou seja, a estabilidade do sistema estaria garantida se os bancos emprestassem até o limite dos seus fundos de fato existentes. A preocupação com a elevada emissão de títulos em períodos de guerra, a fim de financiar os crescentes gastos governamentais, trazia tal inquietação teórica e prática sobre a estabilidade dos mercados financeiros. Para Ricardo os bancos não criam depósitos a partir de seus próprios empréstimos, senão justamente o contrário: os bancos só emprestam aquilo que foi depositado.

Parece que a teoria quantitativa da moeda, defendida também por Ricardo, não tinha espaço para tal noção de capital fictício. Não obstante, Thornton (1965) à época já adiantava certos argumentos keynesianos sobre a criação de crédito. Dizia ele que a expansão dos meios-de-pagamento via aumento de empréstimos bancários poderia estimular o produto ao invés de pressionar a inflação para cima caso a economia se encontrasse com níveis positivos de desemprego; e que, além do ponto de emprego total o produto ainda assim poderia subir, mas com crescimento mais do que proporcional da inflação. Thornton, ademais, sabia que o sistema de empréstimos do mercado monetário tinha outro tipo de instabilidade. Os bancos não tinham nenhuma restrição em emprestar para além do ponto em que começassem a operar pressões inflacionárias. Ele sabia que uma expansão dos empréstimos se justificava per se ex post, já que induzia a expansão da demanda agregada nominal, em um processo cumulativo semelhante ao de Wicksell (1950). 
Por fim, há que explicitar uma ironia da Currency School e sua adesão à TQM, afinal eles aplicavam esta teoria quando na prática ela não valia: "the Currency School employed the quantity theory of money to advocate a form of statutory control of the currency that would have made the quantity theory more or less irrelevant" (Blaug 1995b, p.31). Isto é, o Bank Act invalidava a TQM defendida por seus próprios proponentes, pois tornava a oferta monetária e creditícia endógena! A TQM somente é válida plenamente para o dinheiro inconversível determinado exogenamente, e sua aplicação ao dinheiro conversível da Inglaterra no pós-1821 foi controversa, pois dependia de se as Autoridades Monetárias tinham de fato controle ou não sobre a criação de dinheiro pelo bancos.

\subsubsection{O Bank Charter Act de 1844}

Os ensinamentos de Ricardo foram por diversas vezes reutilizados ao longo do século XIX, e sua figura foi tida como a do descobridor das leis da circulação puramente metálica. Como visto, a conclusão imediata de seus seguidores era a de que as leis do crédito (notas bancárias) deveriam ser submetidas às mesmas leis do dinheiro metálico. Para seus seguidores, as explicações e soluções para as crises eram procuradas na circulação monetária e, portanto, "na mais superficial e mais abstrata esfera" (Marx 1982, p.129).

Com as crescentes dificuldades para trocar notas bancárias por ouro, o Governo Britânico, sob os auspícios de Sir Robert Peel, promulga em 1844 a Lei sobre a reforma do Banco da Inglaterra - o Bank Charter Act ou a Lei de Peel de 1844. A idéia era dividir o banco em dois departamentos independentes, com dois fundos separados, reconhecendo a dupla existência das funções bancária e monetária: (i) Banking Department, incumbido de operações puramente bancárias; (ii) Issue Department, responsável pela emissão das notas bancárias, trocando notas por ouro e ouro por notas com o público. Este último recebe títulos, majoritariamente da dívida pública, correspondente a $£ 14$ milhões mais a reserva metálica, e emite notas bancárias no valor correspondente a ambos estes montantes. Portanto, tais notas deveriam ser cobertas por um fundo especial e sempre disponível em ouro; enquanto que sua parcela não coberta por ouro foi limitada a £14 milhões. Se as notas não estiverem em poder do público, 
então elas estariam em poder do departamento bancário, juntamente com uma pequena quantidade de moedas de uso cotidiano, a reserva deste último. O fundo de reserva do departamento bancário é igual ao excesso de notas, que o banco está autorizado a emitir. O limite legalmente permitido era a emissão de $£ 14$ milhões em notas bancárias sem lastro em reservas de metais (que correspondia à dívida do Estado inglês com o Banco) mais uma quantia referente às reservas efetivas em metais. Os bancos privados foram concomitantemente autorizados a emitir notas bancárias próprias, mas em quantidade restrita.

A reforma intentava objetivar a tese de que as tarefas bancárias devem estar separadas do controle da moeda e de que as notas bancárias devem ser plenamente cobertas pelas reservas. "Certo quantum de metal, insignificante em comparação com a produção global é reconhecido como eixo do sistema" (Marx 1984b, p.92). Para cada nota que retorna ao Banco, este dava em troca o valor correspondente em libras de ouro; e para cada libra em ouro que afluía ao Banco, uma nota de valor correspondente era emitida. Assim sendo, na prática as coisas se passavam como os adeptos da Currency School desejavam, uma circulação de papel que operava como uma circulação metálica pura. Para estes, era exatamente isto o que impediria a ocorrência de crises. Contudo, a prática mostrou justamente o contrário: a divisão em dois departamentos independentes impediu que o Banco da Inglaterra fizesse uso de seus recursos totais em casos de aperto monetário no mercado. Na tentativa de eliminar as crises, o conceito inadequado de dinheiro acabou por agravar os desequilíbrios monetários na Inglaterra. Era perfeitamente possível que o departamento bancário estivesse quase falindo enquanto que o departamento de emissão estivesse com grandes reservas em ouro e mais seus $£ 14$ milhões em notas. Em casos de crise o ouro de um país começa a fluir para o exterior e, neste momento, a Lei Bancária obrigava o Banco a retirar valor correspondente do meio-circulante (Marx 1984b, p.16-17; Marx 1984a, p.308). Assim, justamente quando mais se precisa de liquidez (nos momentos de crise), mais o Banco tem que agir pró-ciclicamente, acabando por reduzir o volume de meios em circulação quando mais o público precisa deles. Ao invés de aliviar, o Banco aperta o cinto mais ainda. A reação dos comerciantes e industriais é, então, entesourar as notas 
que já possuem, acelerando o processo de redução da liquidez e agravando o processo. A legislação impõe um agravamento da crise via ajuste recessivo ${ }^{43}$.

A tentativa vinha no calor dos eventos de 1836-1839, cujas vicissitudes foram diagnosticadas como resultantes da má condução ou mesmo irresponsabilidade por parte dos bancos emissários de notas. Já em 1827, bem antes do Peel's Act de 1844, havia-se adotado o que fora chamado de "Palmer's Rule", segundo a qual o Banco da Inglaterra deveria manter seus empréstimos e investimentos aproximadamente constantes afim de que a liquidez do sistema fosse dada pelos fluxos de ouro - criando na prática, embora não rigidamente, um padrão totalmente metálico.

O aumento na demanda por dinheiro aliado ao aperto monetário somente pode levar ao inevitável majoramento da taxa de juros. A solução inexorável é ou a quebra das empresas ou a revogação do Peel Act. Vemos, então, que o departamento bancário, sob o manto da Reforma, era forçado a funcionar como um banco comum (que age sempre pró-ciclicamente), aumentando a taxa de juros quando havia aperto na oferta monetária e diminuindo-a em caso contrário. O que também serviu de guia para as demais reformas bancárias em outros países, dado que diversos deles mantinham parte considerável de suas reservas internacionais sob a forma de títulos do Tesouro Britânico ou de depósitos bancários em Londres. O apoio obtido em favor desta reforma institucional pode ser em grande parte explicado pelos grandes interesses por um menor controle sobre o sistema bancário - à exceção do controle sobre a emissão das notas ${ }^{44}$.

Todavia, a realidade na época mostrava que a oferta dessas notas dependia de fato da sua demanda e não do fundo de cobertura, contrariando a própria reforma. Durantes as crises, momentos de escassez crítica de dinheiro, a Lei foi temporariamente suspensa para dar margem a um aumento das notas bancárias em circulação sem lastro no fundo de ouro. Um exemplo dessas crises ocorreu em 1847, quando uma paralisação

\footnotetext{
${ }^{43}$ Por que Marx (1984b, p.16-17; 1984a, p.308) não expandiu tal crítica também ao plano internacional? O padrão-ouro global não impunha também um ajuste recessivo em casos de crise mundiais?

44 Os países, entretanto, apresentavam variações no que tangia a suas composições de reservas. Nos sistemas "fiduciários" o Banco Central podia emitir uma quantidade limitada de moeda fiduciária não lastreada em reservas de ouro, a qual poderia ser coberta, na maioria dos casos, com bônus do Governo; mas um aumento na oferta monetária deveria ser lastreado em ouro. Já nos sistemas "proporcionais", as reservas em ouro e em moeda estrangeira tinham um piso proporcional em relação à moeda em circulação. Outros sistemas poderiam combinar um pouco desses dois mecanismos ou até incorporarem certas particularidades. Isso representava a flexibilidade do padrão-ouro dentro de certos limites.
} 
generalizada dos pagamentos levou à falência vários bancos privados importantes. $\mathrm{O}$ próprio Banco da Inglaterra também foi seriamente ameaçado em face às amarras do Bank Act, suspenso temporariamente para permitir a expansão da oferta de notas bancárias, que passariam então a ser garantidas pelo crédito nacional. $\mathrm{O}$ alívio à escassez foi imediato. A divisão estrita do Banco em dois departamentos faria com que o ouro no departamento de emissões ficasse inacessível para o departamento bancário, a não ser que este último mantivesse sua própria reserva de notas. Mecanismo que poderia levar o departamento bancário a recusar ajuda ao mercado mesmo com reservas disponíveis no departamento de emissões, como de fato ocorreu em 1847: “A reserva, considerando-se o banking department, é reserva só para os depósitos. Segundo os Overstone, o banking depatment deve operar apenas como banqueiro, sem levar em consideração a emissão 'automática' de notas. Mas, em tempos de verdadeiro aperto, a instituição, independentemente da reserva do banking department, a qual apenas consiste em notas, vigia com rigor a reserva metálica e tem de fazê-lo se não quiser falir" (Marx 1984b, p.51).

Em 1857 os quatro maiores bancos ingleses exigiram que o Banco da Inglaterra pedisse a suspensão da Lei de 1844, sob a ameaça de retirarem seus depósitos e, assim, levando à falência o banking department. Contudo, apesar dessa possibilidade, no "issue department estão quantos milhões se queiram ..., como garantia da conversibilidade das notas em circulação. Mas isso é por sua vez uma ilusão" (Marx 1984b, p.17). Quando os períodos cíclicos de expansão atingem seu auge, com o ápice das especulações, estoura finalmente a crise, quando então toda a farta liquidez de notas bancárias desaparece rapidamente. Como "nesse sistema de crédito tudo se duplica e triplica e se transforma em mera quimera, isso também se aplica ao 'fundo de reserva', onde por fim se supunha agarrar algo sólido" (idem, p.15).

Em suma, a idéia que aqui defendemos é a de que o Bank Act de 1844 patenteou o caráter contraditório do dinheiro, que se revela ao mesmo tempo como mercadoria e como não-mercadoria. Assim como nos mostra Paulani (1991), o dinheiro é mercadoria porque é mercadoria absoluta (em sua determinação de tesouro) e o dinheiro é nãomercadoria ao ser pura idealidade (em sua determinação de meio-de-pagamento). Daí a famosa frase de Marx de que "somente dinheiro é mercadoria" (quando os negócios prosperam) e que "somente mercadoria é dinheiro" (quando dos desesperos durante as 
crises). Do mesmo modo como ocorria na FE de Hegel, onde a consciência, ao tentar apreender um objeto contraditório através de suas estruturas simples de representação, acabava chegando a uma inadequação entre seu pensar e o objeto que encara: "A lei de 1844 é interessante quanto a seus efeitos porque quer transformar todo o metal precioso existente no país em meios de circulação; ela procura equiparar drenagem de ouro à contração do meio de circulação, e o afluxo de ouro à expansão do meio de circulação. Com isso, estabeleceu-se experimentalmente a prova do contrário. [...] a massa das notas circulantes do Banco da Inglaterra, desde 1844, nunca atingiu o máximo que o Banco estava autorizado a emitir. E a crise de 1857 provou, por outro lado, que em certas circunstâncias esse máximo não basta” (Marx 1984b, p.87 - ênfase nossa).

Isso decorre, como apontava Hegel (2002), do fato de a consciência tentar apreender um objeto contraditório com suas estruturas de representação simples e abstratas. O que a consciência obtém ao fazer isso é a apreensão de um objeto inverso ao qual desejava a princípio. Ela deseja uma coisa e obtém o contrário do que queria. O objeto não realiza, neste caso, o seu próprio conceito. Tenta-se enquadrar o dinheiro como objeto simples, desprovido de contradições internas e como apenas uma mercadoria qualquer. Mas uma investigação dos fatos históricos e alguns poucos dados da época bastaram para mostrar a inadequação desta tentativa. É nas crises que tal contradição é mais bem exposta; momentos em que o dinheiro passa de pura forma a pura matéria (Paulani 1991). Se quando tudo funciona bem o dinheiro não é um problema, quando estoura a crise, ao contrário, todos só falam dele. Se quando tudo funciona sem problemas, o dinheiro é afirmado como um simples véu que recobre as trocas, é só rebentar uma crise que este "véu" é por todos demandado como o objeto mais seguro por excelência. Enquanto o mundo desaba todos querem se segurar em alguma coisa "sólida", mesmo que ela imperceptivelmente também esteja caindo junto com eles. 


\subsection{Marx e a Herança da Banking School: Uma Crítica}

\subsubsection{Entesouramento, Lei do Refluxo e Oferta Monetária}

Marx foi inegavelmente influenciado em seus escritos pelo debate reinante na Inglaterra do século XIX, já que fez a maioria dos seus estudos econômicos em Londres logo após o cume da controvérsia entre a Currency School e a Banking School. Sua oposição às doutrinas da primeira são marcas evidentes em seus textos; porém, sua posição quanto ao legado da tradição anti-quantitativista da segunda não é claro. Nossa tese aqui é a de que Marx foi muito influenciado por esta última escola, ainda que tenha ido para além dela fornecendo-lhe consistência lógica interna. A questão, portanto, não é somente identificar tal herança teórica, senão mostrar que aí jaz uma séria limitação da teoria monetária marxista. Ao criticar em demasia as doutrinas que se apoderavam da TQM, o pensamento marxista toma por seguro doutrinas que de fato não são inequívocas. Os marxistas hoje, inadvertidamente, não se preocupam em tematizar tal influência e acabam por tomar como sólido e seguro uma teoria anti-TQM que, como veremos, também se mostra seriamente deficitária.

Alguns esclarecimentos prévios são inevitáveis. $\mathrm{O}$ primeiro deles diz respeito à Real Bills Doctrine de Smith, desenvolvida no primeiro volume da Riqueza das Nações. Afirma Smith que o crédito bancário, dado que seja criado pelos bancos contra a compra de notas comerciais (bills of exchange) confiáveis (bonna fide) criadas pela própria venda das mercadorias, nunca estará em excesso ao que a circulação naturalmente absorveria. "Banks that solely discount real bills, as opposed to fictitious bills not backed by the sale of goods, can be certain that their reserves will never run low since fresh advances of bank money are regularly counterbalanced by the repayment of old advances" (Itoh e Lapavitsas 1999, p.19). Isto é, se os bancos restringirem seus empréstimos a transações comerciais auto-liquidáveis, emitindo só "notas reais", o crédito bancário nunca excederá as necessidade do comércio; caso este em que o volume do papel-moeda e o volume de crédito tornar-se-iam endógenos (Blaug 1995b, p.30)

\footnotetext{
${ }^{45}$ Smith, em clara oposição a Steuart e John Law, enfatizava os mecanismos produtivos de um país em detrimento dos adiantamentos de crédito. Para ele o nível do produto doméstico é determinado por fatores "reais", como a divisão do trabalho, poupança e a acumulação de capital. Os adiantamentos de crédito não
} 
A subseqüente crítica de Thornton foi acertada e aguda. Dizia ele, contrariamente à Real Bills Doctrine, que: (a) o preço ao qual o crédito é transacionado, qual seja a taxa de juros, é crítico para a determinação da oferta do mesmo; (b) várias notas comerciais "reais" podiam emanar da mesma venda de mercadorias; (c) "notas reais" podiam ser perfeitamente menos confiáveis do que notas comerciais "fictícias" dos comerciantes com boa reputação. Para Thornton "in substance there is no difference between a fictitious bill and a common promissory note, that is, a promise rather than an order to pay for the delivery of goods. Moreover the distinction between 'real' and 'fictitious' bills has little relevance to the practice of a bank" (Itoh a Lapavitsas 1999, p.21-22).

Thornton, em outras, palavras, coloca explicitamente que a formação de capital fictício, se amparada pela boa reputação dos agentes, pode levar à real formação de capital. Em termos dialéticos diríamos que a aplicação da doutrina dos real bills se inverte ao ser aplicada, e quem realiza essa inversão é a existência mesma do capital fictício ${ }^{46}$.

Thornton sabia claramente que os mecanismos de mercado criam crédito fictício e que, assim, a teoria de Smith não valia na prática. Daí o esposamento lógico de Thornton com a Currency School, afinal esta sabia que o mercado não seria capaz de se autoajustar e que se fazia imperativo criar uma restrição jurídica à emissão de crédito. Ou seja, do diagnóstico de que o mercado por si só criava meios líquidos fictícios e de que sua dinâmica não impedia naturalmente que os excessos fossem corrigidos seguia-se que somente uma imposição exógena garantiria a estabilidade do sistema.

A Banking School, por sua vez, ainda que tenham reconhecido de forma inédita a semelhança essencial entre notas bancárias e depósitos bancários ambos como formas de crédito, retoma também o mecanismo de Stuart e o denominam de Lei do Refluxo: o estabelecimento de débitos com os bancos garante o refluxo das notas bancárias

\footnotetext{
aumentam o estoque de capital de um país, senão que somente permite aos capitalistas livrarem-se da tarefa de ter que acumular reservas ociosas de dinheiro, acelerando (mas não aumentando) os circuitos produtivos. Isto é, a tarefa própria dos bancos seria adiantar aos capitalistas precisamente a parte do capital que eles guardariam na forma ociosa de entesouramentos (Itoh e Lapavitsas 1999, p.18-19).

${ }^{46}$ Aqui se percebe que ainda que Ricardo e Thornton fossem adeptos da mesma doutrina, o primeiro não acreditava que valores fictícios pudessem produzir valores reais, enquanto que o segundo afirmava claramente o contrário. Contudo, mesmo com diagnósticos distintos, ambos defendiam uma legislação que colocasse limitações institucionais à expansão do crédito nacional. Ademais, já se percebe que há um ponto de contato entre Thornton e a idéia de capital fictício de Marx; tema que abordaremos nas seções e nos capítulos seguintes.
} 
emitidas em excesso (em relação às necessidades da circulação) de volta aos seus emissores. Foi esta Lei do Refluxo da Banking School - em especial desenvolvida por Tooke e Fullarton - que se contrapôs à teoria ricardiana da sobre-emissão de notas bancárias como explicação dos aumentos de preço e da perda de valor-de-troca da libra inglesa durante as guerras napoleônicas ${ }^{47}$.

O que ocorre se os bancos emitirem notas bancárias em excesso, descontando notas comerciais ou comprando securities? A Banking School afirma que as notas bancárias em excesso retornarão aos bancos emissores via depósitos ou débito, pois as notas adicionais não encontrarão uso no circuito do capital, e os capitalistas as usarão para pagar dívidas contraídas previamente com os bancos. Portanto, o excesso na emissão de notas bancárias somente impacta sobre a liquidação de dívidas contraídas, sem afetar a produção, os gastos ou os preços. Resultado que também é obtido se os bancos criarem contas-correntes com facilidades para tomadores de empréstimo: os cheques serão usados para pagar dívidas prévias, sem efeitos sobre o ciclo do capital (Likitkijsomboon 2005, p.163).

Marx se apoiou sobre os ensinamentos da Banking School, agregando argumentos novos e organizando logicamente as doutrinas desta escola. Dizia ele que esta doutrina, ainda que não conseguisse diferenciar efetivamente dinheiro como dinheiro de dinheiro como capital, entendia que as determinações do crédito são distintas daquelas próprias ao papel-moeda. Se esta escola não trabalhou com a organicidade das funções do dinheiro e com a organicidade do dinheiro com outras categorias econômicas, permanecendo com um raciocínio mecânico, sem dúvida inauguraram uma doutrina que não tomava unilateralmente o dinheiro por uma única função, mas sim como unidade de várias características distintas (Lapavitsas 1994, p.447). O que Marx fez foi encontrar a organicidade lógica que faltava à Banking School.

E aqui reside uma grande influência original que Marx recebeu destes teóricos. Para ambos a trajetória do crédito é circular: o crédito tende a retornar ao seu emissor como débitos contra os quais os créditos emitidos são re-pagos. Marx endossava, desse

\footnotetext{
${ }^{47}$ Além do mais, quando Marx critica o specie-flow mechanism de Ricardo, ele pressupõe um mecanismo desenvolvido por Tooke no qual as variações no comércio internacional não impactam sobre os preços relativos domésticos (Likitkijsomboon 2005, p.166).
} 
modo, a Lei do Refluxo da Banking School (Lapavitsas 2000, p.649), mecanismo natural que garantia a estabilidade do valor, na média, das notas bancárias. Isto é, a oferta de crédito é determinada pelo processo de emissão e refluxo, que expressa a dinâmica de adiantamento e re-pago dos empréstimos bancários; o que tornava a oferta de crédito endógena ao processo de acumulação de capital ${ }^{48}$.

Mas as influências não param por aí. O entendimento de Marx quanto aos entesouramentos como reguladores da circulação monetária foi também fortemente inspirado pelos escritos de Tooke e pela distinção que fazia este autor entre o ouro, o dinheiro fiduciário e as notas bancárias como formas qualitativamente diferentes de dinheiro (Arnon 1984). Segundo Tooke, os economistas, ao não perceberem esta diferença, querem imputar às notas bancárias as tendências do dinheiro fiduciário, embora de fato o papel-moeda lastreado não esteja relacionado com o crédito. As notas bancárias eram uma forma de adiantar crédito bancário, principalmente via desconto de notas comerciais. Notas bancárias estas que, conforme o mecanismo de refluxo, tendiam a voltar a quem as emitia assim que os empréstimos fossem re-pagos pelos clientes ou quando eles comprassem ouro ou depositassem dinheiro em contas-correntes.

\section{O foco no papel monetário do entesouramento é um ponto crucial das teorias anti-} quantitativistas, e Marx o adotou de Stuart e da Banking School (Lapavitsas 2000, p.643). O processo de entesouramento e desentousoramento são centrais para a regulação da quantidade de dinheiro em circulação, o qual torna o valor-de-troca do dinheiro compatível com os valores intrínsecos do dinheiro e das mercadorias. Se para Ricardo a relação é direta entre quantidade e valor-de-troca do dinheiro, para Marx tal relação é mediada pelo entesouramento. Mas o que determina o entesouramento?

A base micro-econômica do mecanismo aprimorado por Fullarton assenta-se sobre o fato de que variações na taxa de juros incentivarão os indivíduos a entesourar ou desentesourar de acordo com o desequilíbrio monetário (por exemplo: se há escassez de dinheiro, a taxa de juros se eleva e induz os agentes a desentesourar via empréstimo de

\footnotetext{
${ }^{48}$ O que fica nítido nas seguintes passagens: “A quantidade de notas [bancárias] em circulação é regulada pelas necessidades de circulação, e toda nota supérflua retorna imediatamente a seu emissor" (Marx 1984b, p.56). "A quantidade das letras em circulação, como a das notas de banco, só é determinada, pois, pelas necessidades da circulação" (Marx 1984b, p.69). "Ricardo's theory of money is completely refuted as its false assumptions that the bank controls the quantity of notes in circulation, and that the quantity of means of circulation determines prices (Marx 1973, p.126).
} 
suas reservas, o que volta a aumentar a oferta monetária e acaba por reduzir os juros) ${ }^{49}$. Marx dedicou várias páginas do Volume II de $O$ Capital a este assunto, mostrando que o entesouramento é aspecto integrante da reprodução do capital. Marx localiza as forças que determinam a quantidade de dinheiro em circulação dentro da dinâmica da acumulação de capital (idem, p.643-644). Ou, em outros termos: Marx enfatizou os fatores endógenos à acumulação de capital no processo de ajustamento da oferta monetária $^{50}$. A análise empreendida no Volume II de $O$ Capital é importante para a crítica de Marx à TQM, já que neste volume se encontram elementos sobre a determinação que vai dos preços à oferta monetária. Aí está um modelo em que o movimento do dinheiro é subsidiário ao movimento do capital, para o qual o entesouramento emerge como mecanismo central na reprodução do capital (Lapavitsas 1994, p.448). O que é bem diverso do que fez Ricardo e outros adeptos da TQM que tipicamente postulam uma oferta monetária exógena e que buscam estabelecer um processo de equilíbrio entre o valor-de-troca e o valor intrínseco do dinheiro. Ainda assim, Marx não elabora uma teoria precisa de como o entesouramento garante a ancoragem do valor-de-troca do dinheiro-mercadoria no seu valor intrínseco; ou melhor: "how the hoarding mechanims operates to maintain the equilibrium is not explained by Marx" (Likitkijsomboon 2005, p.161). Qual a ligação entre um estado de desequilíbrio e as decisões dos agentes quanto a modificarem suas alocações entesouradas?

Neste ponto, não obstante, temos que diferenciar em Marx:

(a) A moeda não apresenta um fluxo circular, mas randômico e que se distancia cada vez mais do seu ponto de partida. Não há "lei do refluxo" para a moeda e para a sua sobre-emissão. O que regula a sobre-emissão de dinheiro conversível, papel-moeda lastreado, é o mecanismo do entesouramento, que libera ou retira

\footnotetext{
${ }^{49} \mathrm{O}$ mecanismo de entesouramento, no esquema de Fullarton usado por Marx, requer que a demanda por entesouramento seja negativamente relacionada com a taxa de juros. Porém, para que o entesouramento seja tão efetivo a ponto de neutralizar qualquer $\Delta M$ exógeno sem que haja $\Delta P$, a função de demanda por entesouramento deve se infinitamente elástica em relação a $\Delta \mathrm{i}$, e exige também que as decisões de gasto dos indivíduos sejam totalmente inelásticas a $\Delta \mathbf{i}$. O que é bem improvável de se encontrar na prática (Likitkijsomboon 2005, p.167).

${ }^{50}$ Lapavitsas (1994, p.455) cita uma passagem do Volume II de $O$ Capital em que Marx diz que as leis da circulação monetária continuam válida para a acumulação de capital: "none of the laws put forward with respect to the quantity of money circulating for the purpose of commodity circulation (Volume 1, Chapter 3) are in any way altered by the capitalist character of the production process".
} 
dinheiro da circulação (de modo inconsciente) conforme as exigências da produção $^{51}$;

(b) A trajetória do crédito, notas bancárias, mostra que elas refluem ao seu ponto de origem, o que corrobora a Lei do Refluxo. Não há entesouramento de notas bancárias, como há de dinheiro conversível, mas existe um mecanismo de refluxo que impede a sobre-emissão de crédito.

Em termos alternativos, diríamos que a o entesouramento está para o dinheiro assim como a lei do refluxo está para o crédito bancário.

Para Marx, assim como para a Banking School, a rejeição da TQM se dava pela prova de que a determinação era dos preços para a oferta monetária, e não o contrário. $\mathrm{O}$ mecanismo para demonstrar que a oferta monetária é endógena era o seguinte. A oferta monetária (mensurada como estoque) se divide, como já afirmara Stuart (Guimarães 1984, p.27-28), em uma parte que circula ativamente e outra parte que não circula, pois foi entesourada. O entesouramento, do ponto de vista individual de um agente, é componente de arbritagem que lhe fornece ganhos com a retenção ou venda de seus estoques de dinheiro. Mas do ponto de vista agregado, esse mecanismo acaba por fazer com que a oferta monetária se adéqüe às necessidades das trocas. Ou seja, se o entesouramento é algo intencional para um indivíduo - que pode ser tanto um consumidor quanto um capitalista - que visa ganhar com arbitragem, para o social este mecanismo é inconsciente e acaba por tornar a oferta de moeda endógena. Portanto, é a

\footnotetext{
51 Segundo Foley (1986), Marx teria argumentado que: (a) uma pequena emissão de papel-moeda inconversível pode ser absorvida pelas necessidades da circulação, pois os agentes podem gastar imediatamente esta nova moeda que recebem, sendo que esta pequena parcela de dinheiro inconversível vai circular conjuntamente com o resto, tendo o mesmo valor do que o dinheiro conversível; (b) se o Estado emitir mais dinheiro do que a circulação pode absorver, os agentes vão querer se livrar deste excesso comprando ouro, o que acaba por criar um mercado para a troca de papel-moeda por ouro (cuja taxa de troca é dada pelo desconto do papel contra o ouro). Neste último caso, existirão duas moedas: o dinheiro conversível com uma taxa de desconto contra o ouro e o dinheiro inconversível com uma taxa menor de desconto contra o ouro. Serão duas moedas com dois poderes de compra distintos. Porém, como na prática só existe uma moeda, os preços das mercadorias vão refletir a taxa de troca do dinheiro inconversível pelo ouro. A TQM diria que este aumento dos preços ocorreria independentemente se o aumento na oferta monetária foi em ouro ou em papel-moeda inconversível, atribuindo $\uparrow \mathrm{P}$ a um excesso de demanda por todas as mercadorias assim que os agentes tentassem gastar esse excesso de dinheiro que agora possuem. A análise de Marx se aplicaria, ao contrário, somente ao papel-moeda, e não ao ouro, sendo que a nova emissão de dinheiro não afeta o preço em ouro das mercadorias. $\mathrm{O}$ mecanismo de aumentos dos preços, para Marx, não se deve a um excesso de demanda por mercadorias, mas sim pela nova taxa de troca entre o papel-moeda e o ouro, isto é, $\Delta \mathrm{P}$ reflete a nova taxa de desconto do papelmoeda pelo ouro. E quando, como no pós-1971, não mais existe esse mecanismo, vale então a TQM? Foley (1986, p.27) aponta que este raciocínio de Marx não seria mais válido para o final do século XX. Veremos isto com mais detalhes no capítulo 3.
} 
existência do entesouramento - seja ele de indivíduos ou empresas - que permite que a determinação $\Delta P \rightarrow \Delta M$ seja estabelecida, pois $M$ é continuamente ajustado entre circulação efetiva e entesouramento (Lapavitsas 1994, p.453). O dinheiro enquanto dinheiro regula o dinheiro enquanto moeda. A TQM, por outro lado, não entendia o dinheiro enquanto reserva de valor e, portanto, não cedia espaço teórico para o entesouramento. Para a Currency School, todo o dinheiro circulava, sem qualquer mediação via reservas ${ }^{52}$.

Ainda assim, no processo de reprodução do capital no volume II de $O$ Capital, o aspecto monetário tem papel secundário; é o fluxo de mercadorias que tem dominância. Os fluxos de dinheiro e de entesouramento são produtos derivados dos fluxos de mercadorias e da acumulação de capital. A função monetária do entesouramento não é a razão de sua formação, pois ele em verdade existe em decorrência do processo de reprodução, para o qual a re-divisão do estoque monetário entre tesouro e circulação efetiva é um elemento derivado. Sendo exatamente este o argumento de Marx contra a suposição de uma oferta monetária exógena da TQM (Lapavitsas 1994, p.456): os fenômenos monetários são subsidiários à circulação de mercadorias e a oferta de meios líquidos é endógena à acumulação de capital. Ou seja, os capitalistas ajustam seus entesouramentos não pela função monetária destes, mas por conta das necessidades da acumulação. Assim, se Marx tomou da Banking School a importância do entesouramento, retirou o caráter monetário deste para impingir-lhe um aspecto estrutural, para o qual o aspecto monetário é secundário e derivado. Portanto, a função monetária dos entesouramentos como reguladores do dinheiro em circulação é um resultado derivado de sua função estrutural para a acumulação de capital (idem, p.457-

\footnotetext{
52 De acordo com Lapavitsas (1994, p.454), o entesouramento para Marx não afetaria a velocidade de circulação da moeda a fim de que ela se ajuste ao nível de preços. A velocidade da moeda (V) seria determinada ex ante por fatores institucionais. $\mathrm{O}$ entesouramento não afetaria $\mathrm{V}$, mas sim sua quantidade (M). Moseley discorda disso. Para ele a velocidade da moeda também se altera: "the quantity of money in circulation would adjust to the sum of prices (i.e., to the 'needs of circulation') by hoarding and dishoarding and/or by a change in the velocity of money" (2005, p.4). Likitkijsomboon (2005, p.166-167) vai mais longe ao dizer que não há diferença fundamental entre dinheiro que circula e dinheiro entesourado, pois a distinção entre ambos é uma diferença de velocidade de circulação, e não uma diferença entre dinheiro ativo e passivo. Os entesouramentos também são parte da circulação. A velocidade (V) agregada seria, então, uma média ponderada das velocidades do dinheiro circulante e do dinheiro entesourado. Ou seja, as movimentações de dinheiro entre dinheiro circulante e tesouro não afetam a oferta monetária agregada, mas sim a velocidade agregada da moeda, de tal maneira que todo $\Delta P Y$ é compensado por $\Delta \mathrm{V}, \operatorname{com} \Delta \mathbf{P}=0$. Dessa maneira, a teoria anti-TQM é uma teoria para a qual a velocidade da moeda seria perfeitamente elástica, que neutraliza qualquer $\Delta \mathrm{PY}$ ou $\Delta \mathrm{M}$ via $\Delta \mathrm{V}$. Porém, como conclui Likitkijsomboon, é raro encontrar tal condição na realidade.
} 
458). Para Marx, analisar variações exógenas na oferta monetária não faz sentido, pois aí se começaria pelo que se deve primeiro $\operatorname{provar}^{53}$.

\subsubsection{A Teoria Monetária de Marx Fragilizada Internamente}

A Lei do Refluxo da Banking School sofreu dois culminantes ataques, um deles ainda no século XIX por parte de Thornton - ao mostrar que a criação de crédito fictício anula o refluxo das notas bancárias -, e outro no século $\mathrm{XX}$, quando os Bancos Centrais passaram a monopolizar a emissão de notas bancárias, colapsando todas as entradas e refluxos do crédito em um único ponto, de forma que hoje não mais se emite notas bancárias através do desconto de notas comerciais (mecanismo este que justamente garantia o refluxo das notas bancárias com os re-pagamentos dos empréstimos).

Para Marx, ainda no que tange ao século XIX, o banco comercial, a fim de emitir notas bancária adicionais, tem que reduzir a taxa de juros, o que induzirá uma tomada de novos empréstimos para o pagamento de dívidas antigas (que estão cotadas a uma taxa de juros maior), sem variação no circuito do capital. Ou seja, reduções na taxa de juros não afetam as decisões de gasto dos capitalistas e nem os preços. Contudo, este raciocínio é incongruente com sua análise da relação inversa entre juros e lucros, a qual implica uma relação negativa entre a taxa de juros e a demanda dos capitalistas por empréstimos. Marx não menciona nada sobre variações na taxa de juros em sua adesão à Lei do Refluxo. Isto é, o mecanismo de refluxo de Marx mostra um sistema bancário acomodativo que responde passivamente às variações nas necessidades da circulação. O que contrasta com a discussão que ele mesmo tece sobre os ciclos e as crises, onde descreve um papel ativo do sistema bancário nas variações dos juros e nas

\footnotetext{
${ }^{53}$ Pode-se pensar, à primeira vista, que haja uma relação estrita entre entesouramento e moeda endógena. Contudo, como nos lembra Mollo (2004, p.324-325), há "uma noção de endogeneidade diferente na abordagem novo-clássica, em particular na sua versão dos ciclos reais, em que a moeda é endógena porque acomoda as necessidades dos ciclos. Mas tal endogeneidade, observe-se, não se relaciona com o entesouramento e, por isso, não implica abdicar da neutralidade da moeda. [...] Na versão novo-clássica dos ciclos reais, embora a moeda bancária seja vista como passivamente criada para atender à demanda, a razão desta também é transacional [...]. Nesse caso, a moeda é endógena mas é neutra, já que o que provoca os ciclos são fatores reais, a moeda apenas viabiliza-os".
} 
políticas de empréstimo (Likitkijsomboon 2005, p.163) ${ }^{54}$. O que parece ser uma falha já presente na tradição anti-quantitativista: "What is absent from the banking school's work, however, is a theory of the movement of interest rates, based on the behaviour of banks and on the cyclical pattern of economic activity already apparent by the middle of the century. Wicksell ... took advantage of this absence to criticise the banking school" (Itoh e Lapavitsas 1999, p.29).

Ademais, tanto o Estado como a Autoridade Monetária não existem no quadro monetário de Marx. Ou seja, ele fez inúmeros comentários acerca do Banco da Inglaterra, mas, em seu tempo, tal banco estava distante de ser um genuíno Banco Central, atuante como único ofertante de papel-moeda e como emprestador de última instância. Ainda assim, mesmo se tal Banco Central existisse no século XIX, seria duvidoso se ele teria esta atuação ativa nos escritos de Marx dada a sua defesa da dinâmica creditícia proposta pela Banking School (Likitkijsomboon 2005, p.163). Ou, posto em termos distintos: a Lei de Refluxo, esposada por Marx, é incompatível com a existência de um Banco Central ativo nos moldes atuais.

Não obstante, o principal ponto que aqui enfatizamos é a crítica de Thornton tanto à doutrina das Real Bills de Smith quanto à Lei do Refluxo de Tooke e Fullarton. Para tanto, vamos apresentar em itens os argumentos (idem, p.167-168):

(a) A Lei do Refluxo de Tooke e Fullarton exige que os bancos sigam a doutrina dos real bills de Smith. Entretanto, mesmo que os bancos efetivamente só descontem real bills de curto prazo, com a expectativa de que a emissão de notas bancárias corresponda ao volume real de transações, e que essas notas retornem periodicamente tão logo as transações sejam concluídas, a sobre-emissão de notas bancárias ainda é possível. Vejamos o motivo;

(b) A mesma quantidade de mercadorias é vendida várias vezes e em cada ato de venda gera-se uma real bill; o que resulta na circulação de várias real bills para a mesma quantidade de mercadorias;

\footnotetext{
${ }^{54}$ A Lei do Refluxo afirma que as notas bancárias emitidas em excesso sobre a compra de securities retornam aos bancos emissores como depósitos, deixando o volume de notas em circulação inalterado. Contudo, essa tese ignora o fato de que os depósitos assim criados constituem poder de compra adicional do púbico (Likitkijsomboon 2005, p.168).
} 
(c) As notas bancárias emitidas finalmente se validarão via variações nos preços: o aumento na oferta de notas em circulação implica aumento de preços e aumento do valor monetários das transações, o que exige ainda mais notas. Há, assim, retro-alimentação entre a quantidade de notas e os preços. Para os bancos individualmente considerados parece que a teoria da Banking School está correta, pois o aumento de preços vem antes do aumento na demanda pelo desconto das notas bancárias;

(d) Os bancos nem sempre sabem distinguir entre "real bills" e "fictitious bills", principalmente quando o ciclo econômico está em sua fase ascendente;

(e) A prática das real bills é tida como limitação à sobre-emissão de notas bancárias, pois revelaria um periódico refluxo dessas notas quando as dívidas forem pagas. Mas isto depende do postulado de que os bancos não variam a quantidade de notas descontadas num certo período de tempo, tal que o influxo e o efluxo de notas sejam iguais. Porém, se os bancos estão aumentando o volume de notas descontadas, o influxo será menor que a emissão e aumentar-se-á o volume de notas em circulação - o que é bem provável em ascensões cíclicas;

(f) Como, então, a Banking School explica as diversas crises financeiras? Tooke e Fullarton culpam os bancos por não seguirem a doutrina dos real bills, tornando o mecanismo de refluxo inefetivo. Portanto, a Lei do Refluxo não é uma lei, pois depende totalmente de uma política de desconto de real bills. Ou seja, não há Lei do Refluxo em um mundo onde os bancos amplamente financiam a produção capitalista via crédito de curto prazo ("real bills") como também através de empréstimos de longo prazo para grandes investimentos ("fictitious bills");

(g) Marx não aceitava a doutrina dos real bills, mas aceitava a Lei do Refluxo. Resta saber como defender esta última sem a primeira;

A suposta dinâmica do crédito mostra qual o problema de se generalizar um princípio econômico que somente vale para um banco individualmente considerado. É verdade que um banco por si só não pode afetar as necessidades do comércio ou a demanda por empréstimos, pois o refluxo é contínuo quando as notas emitidas voltam como pagamentos na data prevista e, caso este banco sobre-emita notas, ele verá sua posição ameaçada na casa de compensações e suas reservas começarão a diminuir. Não resta solução senão contrair a emissão de notas. Entretanto, se todos os bancos atuarem 
simultaneamente e proporcionalmente na sobre-emissão, não haverá piora nas suas posições individuais na casa de compensações. Se os bancos tiverem reservas suficientes e se o Banco Central atuar como emprestador de última instância, os bancos no agregado podem emitir mais notas conforme desejem. Ademais, por conta da concorrência por participação no mercado de empréstimos, um aumento unilateral na emissão de notas por parte de um banco pode levar outro concorrente a fazer o mesmo para defender seu market share, o que se generalizaria facilmente em um período otimista do ciclo econômico (Likitkijsomboon 2005, p.169). Isto é, embora a oferta de crédito necessariamente corresponda à demanda individual, já que o crédito é sempre criado em resposta a um pedido de empréstimo, a oferta total de crédito pode não refletir as necessidades da economia como um todo. Isto é, as conclusões derivadas a partir do nível individual não podem ser generalizadas para o nível agregado do sistema financeiro (Saad-Filho 2002, p.97). Como é o caso dos empréstimos especulativos que inflam o estado de expectativas ou uma bolha na Bolsa, ou quando os bancos financiam a produção de bens não-vendáveis ou não lucrativos. $\mathrm{O}$ excesso de oferta é especialmente presente quando um clima de otimismo é nutrido por aumentos nos preços dos ativos financeiros, fornecendo um ciclo aparentemente virtuoso entre preços e expectativas. O limite do excesso de oferta de liquidez se dá, então, com o aumento da instabilidade financeira e com as crises.

Mas isto não é tudo. Até aqui nos apoiamos muito nos textos de Lapavitsas e de Likitkijsomboon para evidenciar a proximidade existente entre a Banking School e Marx, ressaltando principalmente as deficiências que esta aproximação ensejou para a teoria marxista ${ }^{55}$. Todavia, há um ponto que nem Lapavitsas nem Likitkijsomboon percebem, e que agora passamos a explicitá-lo. Em Marx há uma inconsistência lógica entre sua adesão à Lei do Refluxo e sua análise da formação de capital fictício. Isto é, Marx se contradiz em seus próprios termos. A noção de formação de valores fictícios invalida suas asserções sobre o refluxo do crédito excedente aos bancos emissores. Afinal de contas, que sentido há em adotar a Lei do Refluxo do

\footnotetext{
${ }^{55}$ Likitkijsomboon (2005, p.172) acredita que Marx é tentado a aceitar as teorias da Banking School na ânsia de querer evidenciar que as crises não são fenômenos monetários. E conclui: "The anti-quantity theory, the hoarding mechanism and the law of reflux must be banished from Marx's theory" (idem, p.173). A teoria de Marx não necessariamente envolve uma teoria anti-TQM e nem um conceito de velocidade da moeda perfeitamente elástica. O único requerimento lógico é que o dinheiro seja objeto de entesouramento e que ao menos uma parte do dinheiro adicional seja entesourada, mantendo uma velocidade da moeda variável. A teoria de Marx não é logicamente inconsistente com a teoria de Ricardo assim como modificada por Thornton e Torrens.
} 
crédito ao mesmo tempo em que se afirma que "grande parte do capital financeiro é meramente fictícia"? Marx, portanto, a nosso ver, é fragilizado pelos argumentos de Thornton.

Thornton sabia que a Lei do Refluxo era falsa justamente pela presença de notas bancárias "fictícias". Ou seja, o próprio Thornton - da Currency School - já apontava que a formação de valores fictícios anularia a suposta dinâmica de refluxo do crédito bancário. Qual o problema então? O problema é que Marx adotou as duas teses, a da Lei do Refluxo e a da formação de capital fictício, que são antinômicas entre si! Não há refluxo do crédito bancário justamente porque parte dele é fictício. Marx se contradiz em seus próprios termos, pois se esposa de duas proposições excludentes, e as quais julga serem ambas válidas ao mesmo tempo.

Contudo, tais afirmações ainda exigem maiores qualificações. No capítulo 4 iremos propor uma leitura sobre o que de fato Marx entende por capital fictício. No capítulo 3 também mostraremos que o dinheiro enquanto meio-de-pagamento já é um capital fictício em potencial, embrionário, o que nos permitirá denominá-lo de "dinheiro fictício". Em termos sintéticos, o nosso argumento aqui é o de que a própria natureza do crédito - que é o de adiantar e criar um poder de compra ainda não existente já nega a Lei do Refluxo. O crédito inexoravelmente cria valores fictícios, que futuramente poderão consubstanciar-se como valores reais. É por este motivo que mais à frente caracterizaremos o valor fictício como um vir-a-ser-valor.

\subsection{Teorias Monetárias A Partir da Segunda Metade do Século $X I X$}

Apesar da divisão didática aqui adotada em torno da data da reforma do Banco da Inglaterra, não superestimemos seus efeitos. A divisão é, assim, mais pedagógica do que parece. As verdadeiras mudanças qualitativas do sistema financeiro inglês e da dinâmica de seu Banco Central ocorreriam de forma significativa somente após a década de 1850, e não tanto em decorrência das reformas per se. (Schumpeter 1955, p.729). Desde a crise de 1867, houve grandes mudanças. A exponencial expansão dos meios de transporte - como navios a vapor transatlânticos, ferrovias, telégrafos elétrico, canal de 
Suez, etc. - engendrou o mercado mundial pela primeira vez de fato. Ao lado da Inglaterra, que antes monopolizava a indústria, ganharam lugar uma série de países industriais competidores. A depressão das décadas de 1880 e 1890 também traria à tona questionamentos quanto à responsabilidade do padrão-ouro sobre os movimentos deflacionários e sobre o comportamento cíclico dos preços.

Em 1867, sob a liderança da França, fora organizada uma conferência internacional em Paris acerca dos dilemas do padrão monetário internacional. A tônica da proposta francesa era a da defesa de uma união monetária em âmbito mundial com cunhagem uniforme das moedas, em claro detrimento a um suposto padrão bimetálico defendido por certos países. Contudo, as crescentes pressões por parte dos EUA em favor da prata e do sistema bimetálico, que ganharam maior proeminência nos anos que se seguiram, e em especial nas conferências internacionais de 1878, 1881 e 1892, minaram as propostas iniciais francesas sobre uma possível união mundial em torno do padrão-ouro. Em específico, cabe ressaltar que na conferência de 1892 a proposta alemã, através do economista Julius Wolf, defendia que uma reserva internacional de ouro fosse depositada em um país neutro e que sobre tais reservas se emitissem notas bancárias; idéia esta que 50 anos mais tarde serviria, ainda que em bases bem diversas, como suporte aos acordos de Bretton Woods (Schumpeter 1955, p.1077).

A defesa de um sistema bimetálico contava com dois grupos de adeptos: aqueles países produtores de prata, e outros que viam na introdução da prata uma fonte de aumento nos preços (que haviam sido deprimidos com os anos de recessão), com conseqüentes impactos positivos sobre a produção e sobre as taxas de lucro. Mas o bimetalismo exigia que o sistema internacional fosse ativamente regulado, para que a prata não expulsasse o ouro de circulação. $\mathrm{O}$ preço da prata deveria ser fixado e o mercado perderia parte de sua automaticidade nos ajustes. Já existiam, contudo, propostas de que o sistema deveria ser puramente baseado em papel-moeda inconversível garantido e regulado pelos governos, que comprariam e venderiam títulos públicos para controlar a liquidez e o nível de preços doméstico - assim como mais tarde viria a constituir as operações de open market dos bancos centrais.

Quanto às questões pertinentes às teorias monetárias (que de modo algum estavam descoladas dos problemas práticos e cotidianos), destacamos que a despeito dos avanços 
conquistados com as contribuições ao final do século XIX - que incluíam nomes como Marshall, Wicksell, Walras, Menger, Jevons, Böhm-Baverk - os autores ainda se debatiam com a questão do dinheiro ser ou não ser mercadoria. Como bons exemplos encontramos os dizeres de Wilheim Roscher de que "the false definitions of money divide up into two main groups: those that consider it to be something more, and those that consider it to be something less, than the most salable commodity" (Roscher apud Schumpeter 1955, p.1086), e os de Richard Hildebrand, para quem longe de ser uma mercadoria, o dinheiro era "the very opposite of a commodity" (Hildebrand apud Schumpeter 1955, p.1086). O pragmatismo norte-americano, para evitar evidentes complicações teóricas, se contentaria em apenas afirmas que "money is what money does", no mesmo tom em que décadas mais tarde seria abraçado por Hicks e Friedman ao dizerem que não seria necessário mostrar o que o dinheiro é, mas sim o que ele faz: "Money is defined by its functions [...]. [...] money is what money does" (Hicks 1967, p.1). O que expressa com exatidão a filosofia pragmatista que, ao perguntar o que uma coisa é, afirma que a resposta deve ser dada sobre o que a coisa faz. A coisa é o que ela faz. Para Marx, como veremos, o dinheiro, ao contrário, faz o que ele é e $^{56}$.

Ainda que neste período tais autores soubessem que o dinheiro também exercia a função de reserva de valor e que dinheiro não era um simples numerário, um sistema geral monetário ainda estava ausente. Teoria monetária e teoria do valor e da distribuição eram dois mundos que pouco conversavam entre si. Os preços eram tratados como taxas de trocas, como em uma economia de escambo, onde o dinheiro as transformava em quantidades absolutas, vestimenta monetária que em nada as afetava. Este foi o domínio da chamada "análise real", ainda que suas variáveis pudessem aparecer fantasiadas em termos monetários.

\section{Se a teoria do valor e da distribuição é uma questão logicamente independente da teoria sobre o padrão monetário, então a determinação do aspecto "real" é também independente da determinação do aspecto "monetário" da economia.}

\footnotetext{
${ }^{56}$ Há uma qualificação a mais. Não se trata somente de que a diferença se dá entre de um lado Marx, com a idéia de que "a moeda faz o que ela é", e de outro com os neoclássicos, para quem "a moeda é o que ela faz". A crítica marxista também aponta que a teoria neoclássica não apreende por completo todas as funções da moeda, já que somente entende o dinheiro como meio-de-circulação, meio-de-troca; e não adicionalmente como medida dos valores, tesouro e meio-de-pagamento. Portanto, a frase de Hicks de que "a moeda é o que ela faz" carece de uma apreensão mais completa e orgânica de todas as determinações do dinheiro. Hicks e Friedman não apreenderam por completo o que a moeda faz.
} 
Neste caso, o "bom andamento" do sistema é dado pelas variáveis reais, sendo relegados os distúrbios às influências das variáveis monetárias. Este suposto "lado real” autônomo não é nada além do que simplesmente tratar a economia como um sistema de escambo. Entretanto, como os elementos monetários devem se comportar para que não atrapalhem os processos "puramente reais"? A primeira resposta teórica viria pelo conceito wickselliano de "moeda neutra" (Barger 1935). Mas a busca por uma suposta moeda neutra revelou atingir o objetivo contrario ao desejado:

"So its creation induced a hunt for the condition in which money is neutral. And this point eventually led to the discovery that no such conditions can be formulated, that is, that there is no such thing as neutral money or money that is a mere veil spread over the phenomena that really matter - an interesting case of a concept's rendering valuable service by proving unworkable” (Schumpeter 1955, p.1088-1089)

Segundo Marx, em suas Teorias da Mais-Valia (1863, Cap.17, item14), é justamente esse fato que impede que o conceito de crise seja devidamente apreendido. Tratar o dinheiro como um véu e a economia como se fosse um sistema de simples escambo, é o mesmo que tratar venda e compra como uma identidade imediata. Suprimir o dinheiro é suprimir a contradição entre trabalho individual e trabalho social abstrato. Segundo Marx, a crise somente pode surgir logicamente quando as trocas são intermediadas pelo dinheiro; ela resulta da dissociação da unidade entre compra e venda. E, ao abordarmos a economia como uma economia de escambo, como fizeram e ainda fazem muitos, a oposição entre trabalho individual e trabalho social é ignorada por completo. A questão central é que o dinheiro, segundo a teoria marxista, não é produzido individualmente pelo trabalho.

Mesmo que fosse perfeitamente possível circunscrever o dinheiro em um compartimento teórico autônomo, ainda assim restaria o problema lógico da determinação do valor-de-troca do mesmo. Por um lado, a abordagem dos númerosíndices providenciava uma saída pragmática: "Such an indication is called an 'index number' of the price level. Its reciprocal indicates, of course, the purchasing power of money” (Fisher 1922, Cap.10, §1). A escola austríaca, por outro lado, desejava aplicar sua teoria da utilidade marginal também ao caso do dinheiro. Mas aqui a coisa fica mais 
ainda complicada, pois se patenteia nesta tentativa as antinomias entre valor-de-troca subjetivo e valor-de-troca objetivo, bem como entre os aspectos antinômicos individual e social. Neste caso, o indivíduo precisa saber de antemão o que o dinheiro pode objetivamente comprar, antes de imputá-lo com algum valor subjetivo segundo um mapa de preferências e o princípio da utilidade marginal. $\mathrm{O}$ resultado deste exercício lógico redunda em um pensamento circular que não leva a lugar algum. Desse modo, o dinheiro, através da abordagem da utilidade marginal, não pode ser mercadoria e nem pode ser tratado como se fosse uma, pois seríamos levados a um problema lógico insolúvel. Vale ressaltar, além disso, que a tentativa de Menger era contrária a de Fisher, já que enquanto este último buscava o valor do dinheiro no nível geral de preços, aquele ansiava uma explicação no comportamento atomizado dos indivíduos. Ademais, existiam também aqueles que julgavam ser o dinheiro nada além do que uma convenção institucional declarada a partir do poder judiciário do Estado. Como um exemplo, para o economista alemão Georg Knapp, "Money is a creature of law. A theory of money must therefore deal with legal history" (Knapp 1924, p.1) - embora ele tenha sido incapaz de formular qualquer tipo de teoria não-metalista que explicasse a determinação do valor do dinheiro ou, ainda, das taxas de câmbio ou do valor de uma moeda nacional fora da sua própria esfera doméstica ${ }^{57}$.

Quanto às teorias bancárias e do crédito neste período, observa-se que em grande medida não houve grandes avanços quando comparadas aos descobrimentos de décadas anteriores, apesar dos novos esclarecimento e refinamentos. Excetuando o próprio Marx, parece que os autores europeus ainda se aferravam à concepção do sistema bancário segundo a perspectiva comercial, das notas comerciais, e sem contribuições originais quanto a isso. Isto substancialmente significava a prevalência da "commercial theory of banking which made the commercial bill or, somewhat more generally, the financing of current commodity trade the theoretical cornerstone of bank credit" (Schumpeter 1955, p.1111). O que também engendrou certa miopia por parte da teoria quanto ao real funcionamento dos mercados bancários, pois continuava a postular as políticas de redesconto como instrumento primário de controle. A commercial theory of banking entendia que se o sistema bancário se limitasse a financiar as "necessidades do comércio", os setores financeiro e produtivo cresceriam pari passu e sem distorções. O

\footnotetext{
${ }^{57}$ Para uma crítica a Knapp, rever a primeira nota deste capítulo.
} 
problema era que, assim como já haviam apontado Tooke e Ricardo, não existe tal coisa como uma demanda quantitativamente definida por empréstimos, sendo ela tão resultado da propensão dos bancos a emprestarem e de suas respectivas taxas cobradas quanto da demanda dos produtores por crédito. Além de empiricamente irrefutável, a mera confinação a descontos de notas comerciais "confiáveis" (bona fide) e ao suprimento dos "devidos" créditos por parte do sistema bancário não garantiam a estabilidade do nível de preços, nem dos negócios em geral e nem a solvência dos bancos em períodos de crise. O que somente viria a ser incorporado na teoria monetária com a idéia de "processo cumulativo" introduzida em 1906 por Wicksell (1950), cuja contribuição era um ataque tanto à noção de moeda como um véu quanto à chamada Lei de Say $^{58}$.

\footnotetext{
${ }^{58}$ Sobre isso ver: http://cepa.newschool.edu/het/essays/money/cumulative.htm
} 


\title{
Capítulo 3
}

\section{A Teoria Monetária de Marx: Sua Atualidade e Seus Limites}

\author{
"Para cada problema complexo, \\ sempre há uma solução simples, \\ clara e errada." (H.I.Mencken)
}

Somente podemos entender a atualidade da teoria monetária de Marx se primeiro entendermos quais são suas limitações. É deste mote que parte este capítulo. Vamos extrair o máximo possível das categorias marxistas justamente por reconhecer seus limites. Não obstante, apesar de circunscrita ao seu contexto histórico, a análise de Marx é "viva" por respeitar o movimento do objeto, sendo desta vivacidade donde tiraremos os desdobramentos para atualizá-la em face do capitalismo pós-1971.

Lembremos os termos de Hegel: o negativo, que aparece como uma falha, como uma desigualdade entre sujeito e objeto, ou do objeto consigo mesmo, é na verdade a alma e o motor de todo o processo. O negativo não é o que invalida o conceito, senão o que o faz mover-se.

\subsection{Nem Economia Real e Nem Economia Monetária}

Nossa primeira asserção é a de que tratar o capitalismo como uma "economia real", em que o dinheiro é um óleo lubrificante, e tratá-lo como uma "economia monetária", são ambas abordagens insuficientes e dissimulantes. A idéia de uma "economia real" não encontra lugar lógico para o dinheiro como universal-concreto, e a idéia de "economia monetária" dissimula o que há de específico no capitalismo: 
"D-F [compra de força de trabalho com dinheiro] passa por característica, por marca distintiva da economia monetária, porque o trabalho aparece aí como mercadoria de seu possuidor e o dinheiro, como comprador - em virtude, portanto, da relação monetária (compra e venda de atividade humana). Mas o dinheiro já aparecia em tempos remotos como comprador dos chamados serviços, sem que D se transformasse em capital-dinheiro ou sem que mudasse o caráter geral da economia. [...] O característico não é que a mercadoria forca de trabalho seja comprável, e sim que a força de trabalho apareça como mercadoria" (Marx 2000, p.44 - ênfase nossa)

Portanto, é como se o capitalismo tivesse duas aparências: uma em que o dinheiro é supérfluo, como fazem os autores neoclássicos, e outra em que o dinheiro é “tudo", como fazem os pós-keynesianos. O que fica ainda mais claro na seguinte passagem, também do Volume II de $O$ Capital:

“A relação de capital apenas surge durante o processo de produção porque ela já existe no ato de circulação [...]. Não é o dinheiro que, por sua natureza, estabelece essa relação; é antes a existência dessa relação que pode transmutar uma simples função monetária numa função de capital" (Marx 2000, p.45)

Ou seja, o capitalismo não é uma economia sem dinheiro e tampouco uma economia monetária.

\subsection{Dinheiro Enquanto Moeda e a Moeda Inconversível: Da Realidade Efetiva à Realidade}

\subsubsection{O Dinheiro Enquanto Moeda}

Se as "relações burguesas aparecem ... como relações monetárias" (Marx 1982, p.55), a análise inicial do dinheiro deve começar por suas formas imediatas, e não por suas formas mais elaboradas, como o crédito. Adentraremos, então, a "esfera mais superficial 
e mais abstrata desse processo, a esfera da circulação monetária” (Marx 1984b, p.74). Não obstante, assim como já mostrava Hegel, apesar de superficial, nada tem de inessencial. Aliás, muito pelo contrário, tal superficialidade e abstração são momentos necessários de aparição de sua essência ${ }^{59}$.

A análise de Marx implica que as funções do dinheiro derivam de sua essência, ao contrário do que pressupõem neoclássicos e pós-keynesianos, que derivam a essência do dinheiro a partir de suas funções (Saad-Filho 2002, p.92): "Marx's approach to money implies that "what money does follows from what money is"" (Fine e Lapavitsas 2000, p.370; Lapavitsas 1994, p.449) ${ }^{60}$. Além disso, a teoria monetária de Marx tem uma diferença essencial em relação às teorias neoclássica e pós-keynesiana. Para a teoria do valor-utilidade $^{61}$, trabalho e capital são pagos a partir do produto conjuntamente gerado, assim como expresso na função de produção $y=f(k, \tau)$ - para a qual figuram capital e trabalho como insumos produtivos -, e de acordo com a contribuição de cada fator; enquanto que para a teoria do valor-trabalho o trabalho é pago pelo capital e a remuneração deste último é residual: "capitalists and workers do not confront each other directly over the shares of the national product, firstly because the wages are advanced, whereas profit is the residual and, secondly, because disputes generally involve income levels rather than shares" (Saad-Filho 2002, p.101).

A distinção entre pós-keynesianos e marxistas é, contudo, ainda mais fundamental. Tanto Minsky quanto Keynes trabalham a ciência econômica dentro dos mesmos marcos científicos da teoria neoclássica. Para eles o capital é um fator produtivo, que se compõe de máquinas, instrumentos, instalações, tecnologia etc. Para teoria marxista, por outro lado, o capital não é um fator produtivo, mas sim um movimento, movimento este que internaliza seus pressupostos, que produz o que ele mesmo coloca como précondição. Capital é, para Marx, sujeito. Mas o que significa isso? Sujeito, em sua conotação hegeliana, não é uma pessoa, um indivíduo, mas algo que produz o seu

\footnotetext{
${ }^{59}$ Começamos nossas asseverações a partir da forma moeda. Para uma apresentação dialética de todas as formas entre a mercadoria e o capital ver Fausto (1989a, 1989b e 1997)

${ }^{60}$ Se bem que a noção de que "o que o dinheiro faz define o que ele é" não é de fato o problema central. O que Marx tem a dizer de mais importante sobre isso não é simplesmente dizer que para ele "as funções do dinheiro derivam de sua essência" enquanto que para seus adversários "os usos do dinheiro definem sua essência", mas sim que seus adversários nem chegam a apreender os usos e funções do dinheiro em sua plenitude e organicidade - este é o ponto. Isto é, nem quando Hicks ou Friedman dizem que o dinheiro se define pelas suas funções eles de fato aí apreenderam todas as funções do dinheiro.

${ }^{61}$ Para o utilitarismo, ponto final do Iluminismo, "o útil é o objeto enquanto nele penetra o olhar da consciência-de-si, que descobre a verdadeira essência do objeto: a de ser penetrável ou de ser-para-outro" (Menezes 1992, p.49).
} 
próprio desenvolver (seria como um motor que faz um carro andar e que também constrói a própria estrada neste seu caminhar; anda e cria o caminho por onde anda).

O dinheiro é, antes de tudo, um particular que é uma existência social, "nothing more than a social relation" (Marx 1973, p.144). As mercadorias e a moeda são particularidades e, por isso mesmo, modos de expressão do universal, do social; elas são "encarnações autônomas, expressões do caráter social da riqueza. A riqueza da sociedade existe apenas como riqueza de indivíduos, que são seus proprietários particulares" (Marx 1984b, p.92). A riqueza é um universal que se mostra somente através de seus particulares, e somente assim pode aparecer. O universal nunca se mostra imediatamente como universal, como social, mas mediatamente através de seus particulares. A mediação entre o particular, a mercadoria, e o social/universal, é realizada pela forma dinheiro: "só por intermédio do dinheiro realiza-se a riqueza do indivíduo como riqueza social" (Engels in Marx 1984b, p.93). O dinheiro é a forma que corporifica a natureza social desta riqueza. E o particular somente pode se realizar como particular se for universal: "my product is a product only in so far as it is for others; hence suspended singularity, generality" (Marx 1973, p.196). O particular somente se realiza como particular através de seu contrário. $\mathrm{O}$ produto somente se afirma como algo particular se de fato for aceito universalmente.

Agora, atentemos: dinheiro enquanto moeda é dinheiro como meio (medida dos valores e meios-de-circulação), e pertence ao ciclo M-D-M, aparência da circulação; dinheiro enquanto dinheiro é dinheiro como finalidade (tesouro e meio-depagamento), e pertence ao ciclo D-M-D, essência da circulação.

A passagem da forma mercadoria à forma dinheiro somente é possível porque já existe algo de universal (valor) e particular (valor-de-uso) no interior da mercadoria; ou seja, somente é possível derivarmos logicamente o dinheiro por ser a mercadoria unidade de contrários, particular e universal. É essa a contradição que impulsiona o desdobramento lógico. Há algo de indeterminado nas determinações da mercadoria. A determinação desse indeterminado é a necessidade que nos leva à forma superior e mais desenvolvida. Uma forma particular somente pode passar a uma forma universal se já na constituição do particular existir um momento de universalidade. A não-capacidade do particular em lidar com essa sua potencialidade universal, indeterminada, mostra 
justamente sua inadequação por ser forma particular. A inadequação do particular é exatamente ser particular, não-universal.

O dinheiro, este singular, universal-particular, é a negação da mercadoria, o particular, pois enquanto que a última é valor ideal pressuposto e valor-de-uso real posto, o primeiro, ao contrário, é valor real posto e valor-de-uso ideal pressuposto (Fausto 1997, p.103-105). Se a mercadoria está posta como particularidade, o dinheiro está posto como seu contrário, como generalidade, sendo o trabalho a "medida efetiva" (Marx 1982, p.57) entre particular (mercadoria) e universal (dinheiro). A forma dinheiro é, portanto, a relação da mercadoria com ela mesma por meio do seu outro, que ela mesma efetivou e que nele se nega para conservar-se: “[...] money relations develop, together with the contradiction immanent in the money relations, in the relation of the product to itself as money" (Marx 1973, p.146 - ênfase nossa).

Todas as mercadorias são evanescentes; o dinheiro, ao contrário, é a mercadoria nãoevanescente. $\mathrm{O}$ dinheiro repõe a contradição da mercadoria em um patamar mais elevado, mais geral. O dinheiro resolve a contradição da mercadoria generalizandoa. Se a mercadoria era a expressão da contradição entre particularidade e universalidade, o dinheiro é também a expressão entre a condicionalidade (ser uma mercadoria específica) e a incondicionalidade da troca (não-ser mercadoria; ser geral). O dinheiro revela a necessidade de uma medida geral de troca não sujeita às intempéries e oscilações de produções específicas e casuais, e que seja independente das particularidades de todos. Quanto mais especializada, multifacetada e interdependente a produção for, maior a exigência de uma meio universal de troca que independa das particularidades. E, sendo resultado da divisão do trabalho, torna-se da mesma maneira seu pressuposto. Se o trabalho é o universal-abstrato - abstração objetiva, real, produzida pela própria dinâmica social ${ }^{62}$-, o dinheiro é agora o universal-concreto.

\footnotetext{
${ }^{62}$ Aqui o sentido do termo "produzir" é forte, pois denota precisamente que a sociabilidade, a dinâmica social, produz uma abstração, uma redução. As particularidades produzem, engendram, formam, desenvolvem, sua própria abstração.
} 


\subsubsection{A Moeda Enquanto Medida dos Valores}

A primeira função da forma moeda é servir de medida dos valores, forma necessária de manifestação da medida tempo de trabalho abstrato. Contudo, ela própria não tem preço, não se refere a si própria como equivalente de si mesmo. O preço, como forma de valor, é forma puramente ideal ou mental, diferenciando-se de sua forma tangível ou real e, por isso, só faz uso de dinheiro ideal ou imaginário. Contudo, embora apenas o dinheiro ideal meça os valores, o preço depende totalmente da substância real do dinheiro. Dito de outra maneira: para servir como medida dos valores, necessita-se somente de dinheiro ideal; mas para determinar os preços, necessita-se saber qual a substância real do dinheiro.

O dinheiro não recebe o valor do ouro, mas sim o seu valor-de-troca; sendo essa confusão entre o valor e sua forma específica, segundo Marx, a fonte do equívoco de tratar o valor do dinheiro como imaginário e arbitrário. Onde o uso de papel-moeda ou outro representante simbólico fez muitos acreditarem que dinheiro era simples símbolo. Mas "nessa idéia falsa se contém o pressentimento de que a forma dinheiro de uma coisa é exterior à própria coisa, sendo pura forma de se manifestarem relações humanas atrás dela ocultas" (Marx 2002, p.115 - ênfases nossas).

Entretanto, como podemos ver, nesta parte do desenvolvimento lógico Marx ainda está preso ao ouro como lastro. Diz ele que a mercadoria tem de desprender-se de seu corpo natural para se efetivar como valor-de-troca, tem de "transformar-se de ouro idealizado em ouro real”, precisa transubstanciar-se: "o ouro funciona como medida ideal do valor apenas porque já operava, no processo de troca, como mercadoria dinheiro. Atrás da mensuração ideal dos valores, espreita o metal sonante" (Marx 2002, p.130-131). Neste sentido, nossa pergunta torna-se imediata: se não há mais ouro como matéria real do dinheiro, como chegar à forma preço? Ou melhor: por que a determinação da moeda como medida dos valores constitui um problema a ser investigado? A resposta encontrase no próprio Marx: "In so far as it realizes the price, its material existence as gold and silver is essential" (Marx 1973, p.209). Este é o problema: Marx transforma valores em preços pressupondo a essencialidade da matéria do dinheiro. Quando o dinheiro perde tal matéria, como determinamos os preços? Contudo, deixemos por alguns 
instantes tal pergunta em suspenso, retomemos nosso raciocínio, e voltemos a ela mais a frente ${ }^{63}$.

Desempenha a moeda, não obstante, dois papéis distintos. A tabela a seguir resume esquematicamente esses papéis:

\begin{tabular}{|c|c|}
\hline $\begin{array}{l}\text { Medida dos Valores } \\
\text { (measure of value) }\end{array}$ & $\begin{array}{l}\text { Padrão de Preços } \\
\text { (standard of prices) }\end{array}$ \\
\hline $\begin{array}{l}\text { É representante social, equivalente } \\
\text { geral, do trabalho humano }\end{array}$ & $\begin{array}{l}\text { É um peso fixado, convencionalmente, de ouro } \\
\text { (determinado peso de ouro deve ser escolhido } \\
\text { unidade de medida) }\end{array}$ \\
\hline $\begin{array}{l}\text { Mensura as mercadorias como } \\
\text { valores }\end{array}$ & $\begin{array}{l}\text { Mede as quantidades de ouro segundo uma } \\
\text { quantidade fixa de ouro, e não o valor de uma } \\
\text { quantidade de ouro segundo o peso de outra }\end{array}$ \\
\hline Converte valores em preços & É a medida da quantidade de ouro dos preços \\
\hline $\begin{array}{l}\text { Desempenha o ouro esta função por } \\
\text { ser também produto do trabalho, } \\
\text { trabalho objetivado, e por ter seu } \\
\text { valor potencialmente variável }\end{array}$ & $\begin{array}{l}\text { Desempenha o ouro esta função por ser } \\
\text { determinado peso de metal, e por ser fixado } \\
\text { como unidade de peso invariável. Melhor } \\
\text { funciona quanto menos variar seu padrão }\end{array}$ \\
\hline Sua materialidade é essencial & Sua materialidade é inessencial \\
\hline $\begin{array}{l}\text { Nesta determinidade, a quantidade de } \\
\text { dinheiro (ou de ouro) não faz } \\
\text { diferença }\end{array}$ & A quantidade de ouro faz diferença \\
\hline
\end{tabular}

Novamente, vemos que enquanto medida dos valores, a moeda desempenha esta função por ser também produto do trabalho. Mas o atual dinheiro sem lastro não o é. Dinheiro inconversível, como hoje temos, não tem substrato material produzido pelo trabalho. " $[\mathrm{H}]$ ow are money prices determined when gold disappears as the general equivalent and is replaced by inconvertible paper money with no intrinsic value?" (Carchedi 1991, p.165). Poderíamos afirmar que com o fim do lastro-ouro o dinheiro perdeu sua função de "medida dos valores" e que, portanto, atualmente só serve como "padrão de preços"? Ao que tudo indica, chegamos a um impasse teórico, pois Marx define como essencial uma materialidade que não mais existe.

Está posta uma necessidade técnica de passarmos da "unidade medida" ao "padrão" (Marx 1982, p.59). As quantidades de ouro são mensuradas por seu peso e, assim, o

63 Quando nós dizemos "dinheiro inconversível" ou "dinheiro sem lastro", nos referimos sem ambigüidades à forma atual que o dinheiro assume no padrão dólar-dólar. Forma esta que, como defendemos, perdeu toda e qualquer materialidade. Isto é, não é uma forma descolada de sua matéria, mas uma forma que a perdeu por completo. 
padrão já se encontra pronto. O peso dos metais usados como moedas fornece esta passagem da medida dos valores ao padrão de preços. $O$ ouro figura como medida dos valores por ser tempo de trabalho objetivado e por ser valor variável; e figura como padrão de preços por ser determinado peso de metal e por ser fixado como unidade de peso invariável. Se a troca isolada pode determinar um preço, a alta freqüência destas trocas pode fixar um padrão. Como vimos em nosso capítulo 2, a confusão entre essas duas concomitantes determinações levou muitos teóricos a não conseguirem apreender adequadamente a forma dinheiro. Esta separação, como veremos, é o ponto nevrálgico para entendermos como a circulação monetária pôde conservar as denominações de peso de metais face às suas evidentes variações de peso. É pela sua determinação como padrão dos preços que podemos assimilar o fato de que as denominações monetárias dos pesos passaram a designar pesos diferentes. Dado que a determinação da unidade de medida, por um aspecto, é puramente convencional e que, por outro, deve ser geral e necessária, "ela precisou tornar-se legal. O aspecto puramente formal desta operação caiu, portanto, na alçada dos governos" (Marx 1982, p.60).

\section{Como padrão de preços o dinheiro se mostra duplamente como ilusão fetichista e}

convencionalista. Fetichista porque o natural (o ouro como matéria) serve ao social; convencionalista porque o social é em verdade uma convenção (Fausto 1997, p.96-97).

$\mathrm{O}$ processo de nominalização da moeda (de descolamento da forma em relação à matéria) se faz com uma mudança no caráter da simbolização: se no primeiro momento a simbolização é produzida na ordem objetiva, pois nasce do próprio processo de circulação, no segundo a simbolização é determinada pelo Estado, assumindo assim a característica externa de uma convenção (Fausto 1997, p.113).

$\mathrm{O}$ aspecto convencional e legal do padrão de $\operatorname{preços}^{64}$ e a transformação dos pesos dos metais em unidades monetárias, em nomes monetários, tornam o dinheiro, agora, moeda de cálculo. Dessa forma, a riqueza é fixada do ponto de vista do valor de troca, e necessita-se do ouro somente enquanto representação. Como moeda de cálculo, o

\footnotetext{
${ }^{64}$ Na Ciência da Lógica (“Grande Lógica”), Hegel (1816, §714) diz sobre o "padrão” [Maßtab]: "A measure taken as a standard in the usual meaning of the word is a quantum which is arbitrarily assumed as the intrinsically determinate unit relatively to an external amount. Such a unit can, it is true, also be in fact an intrinsically determinate unit, like a foot and suchlike original measures; but in so far as it is also used as a standard for other things it is in regard to them only an external measure, not their original measure. [...] But for other things such a standard is still more something external. [...] Moreover, a universal standard ought only to serve for external comparison".
} 
dinheiro serve apenas idealmente: "accounting money is an ideal measure" (Marx 1973, p.190), sendo seus limites aqueles impostos pela imaginação. Como moeda ideal, sua quantidade real pouco importa, já que nenhuma peça de fato é usada para esta posição, e sua posição aqui é necessária somente como categoria, como uma relação mental. Para circular realmente, a moeda precisa antes circular idealmente. Portanto, para Marx assim como para a Banking School - os preços são pré-condição da circulação monetária.

Fica novamente patente a distinção que deve ser feita entre fixação das denominações de cálculo de pesos específicos de ouro e a fixação do valor desses mesmos pesos. $\mathrm{O}$ que é legalmente fixado é a denominação monetária, não o seu preço. O valor do ouro é variável por ser variável sua unidade de medida, o tempo de trabalho abstrato. Se o ouro serve como elemento de determinação de preços e como moeda de cálculo, ele não somente não tem preço fixo como tampouco tem preço algum. Para ter preço, o ouro, o equivalente geral, teria de deixar de ser equivalente geral, pois a forma preço é justamente a expressão simples do valor na mercadoria que serve de equivalente geral. O ouro não pode expressar-se em si mesmo. O equivalente geral não tem preço exatamente por já ser equivalente geral. Falar em "preço do ouro" ou mesmo "preço do dinheiro" seria uma contradição em termos, termos estes que se repelem mutuamente. A mesma mercadoria não pode ocupar ao mesmo tempo a forma relativa e a forma equivalente do valor. Ouro teria de deixar de ser dinheiro para expressar seu preço $^{65}$.

Contudo, as determinações "padrão de preços" e "moeda de cálculo" são formas pertinentes à aparência do dinheiro na circulação. Entender a essência da moeda é apreender a transformação de "medida dos valores" em "padrão de preços". É esta passagem que revela a origem da forma moeda na própria mercadoria. Ater-se às formas fenomênicas implica apreender o dinheiro como pura convenção. Contudo, tampouco basta assimilar a forma dinheiro como unidade imediata do tempo de trabalho. As mercadorias não se relacionam diretamente como produtos de trabalho social; muito

\footnotetext{
${ }^{65}$ Aqui já há inerentemente uma crítica ao bimetalismo. Duas mercadorias que excluem todas as outras, por serem dinheiro, também se excluem entre si. Quando ouro e prata vigoram concomitantemente, os indivíduos tentam tratá-los como se fossem única e mesma matéria. Existe, nesse caso, um problema prático de tensão entre a fixação legal da proporção de valor entre ambos e suas variações individuais de valor
} 
pelo contrário, elas são trabalhos privados que devem se realizar através de sua alienação como trabalhos sociais. Há, assim sendo, uma mediação, uma negação. Trabalho privado não é diretamente trabalho social; ele precisa antes ser negado como privado para mediatamente se tornar social. O tempo de trabalho contido nas mercadorias é indiretamente social; e não é, nem de longe, tempo de trabalho comunitário, como se os indivíduos fossem diretamente associados. Mercadoria não é diretamente dinheiro ${ }^{66}$.

\subsubsection{A Moeda Enquanto Meio-de-Circulação}

Como intermediário das trocas, o dinheiro encarna sua segunda função, é, assim, meiode-circulação da forma simples de circulação das mercadorias ${ }^{67}$. Se como medida dos valores sua materialidade era essencial e sua quantidade inessencial, agora como meiode-circulação, ao contrário, sua materialidade passa a ser irrelevante, podendo tornar-se até um símbolo ou mesmo signo ${ }^{68}$, e sua quantidade em circulação passa a ser essencial. Se como medida dos valores o dinheiro era posto idealmente, pode ele agora, como meio-de-circulação, ser posto como símbolo.

Com o dinheiro metálico, os nomes originais das moedas designavam seus pesos em metal nobre; isto é, o padrão de medida dos preços era também o padrão de medida dos pesos. Os nomes do dinheiro são, primitivamente, nomes de pesos. Entretanto, ao longo dos anos, os pesos em metais das moedas, por conta de diversos fatores, começam a divergir de seus pesos originais; começa a haver um descolamento entre denominação (designação monetária, peso nominal) e valor do dinheiro (designação do peso metálico, peso real). O padrão monetário revela-se uma convenção com validade geral e regulado por lei. Dinheiro é, então, "dinheiro de conta", "objetividade simples e puramente social”. Cunhagem e padrão de preços são atribuições do Estado. Mas, embora haja esse descolamento, os nomes das moedas, em um dado padrão, ainda continuam a significar,

\footnotetext{
${ }^{66}$ Sobre as conseqüências teóricas e práticas de se tomar o dinheiro diretamente como uma mercadoria, não permeada por uma negação que caracteriza a passagem do particular ao geral, ver (Marx 1982, p.6668). Nestas páginas as idéias do dinheiro como "bônus de trabalho", "ticket de tempo de trabalho", "átomos de valor", assim como proposto pela Escola de Birmingham, por Thomas Attwood e por John Gray, são duramente criticadas.

67 “"...] tudo isso se aplica apenas à forma simples de circulação das mercadorias” (Marx 2002, p.143). O dinheiro, porém, não faz circular as mercadorias, "but their titles of ownership" (Marx 1973, p.194).

${ }^{68}$ Mais a frente vamos melhor qualificar esta distinção entre símbolo e signo, que tem sua origem nos escritos de Hegel.
} 
ao mesmo tempo, valor e peso em metal. As designações mantêm, assim, uma aparente identidade que não mais se revela como identidade de conteúdo ${ }^{69}$. Seria, portanto, errôneo acreditar que o ouro é estimado por sua própria substância material e que seu preço é fixado pelo Estado. Não podemos confundir fixação de nomes contábeis de pesos de ouro com sua determinação de valor.

A dissociação entre peso nominal (existência funcional) e peso real (existência metálica) das moedas de ouro evidencia a dissociação entre peso do ouro como padrão de preços e peso do ouro como meio-de-circulação. Cessa o ouro, pois, de ser o verdadeiro equivalente das mercadorias e cujos preços realiza. Esta é a "tendência natural" do comércio em converter a moeda em "simulacro" da quantidade de ouro que deveria representar. É o próprio curso do dinheiro que "traz latente a possibilidade de o dinheiro metálico ser substituído, em sua função de moeda, por senhas feitas de outro material, por meros símbolos” (Marx 2002, p.152). Contudo, Marx diz que o dinheiro pode ser substituído por signos quando funciona como moeda em sua determinação específica de meio-de-circulação: "só pode operar-se essa substituição enquanto exerce exclusivamente a função de moeda ou de meio de circulação" (Marx 2002, p.155).

A função social do "dinheiro simbólico", "dinheiro papel”, do símbolo, é convencional e regulada por lei, com curso forçado para ter validade social própria do dinheiro, independente de seu próprio valor. É a existência funcional que absorve a existência material. Mas, para ser signo de valor, não precisa o dinheiro ser papel-moeda, o próprio descolamento entre valor nominal e peso real das moedas em ouro já é considerado por Marx como a criação de símbolos de valor ${ }^{70}$. Entretanto, o dinheiro como símbolo, para Marx, opera com o mecanismo do padrão-ouro. Ainda que "mero símbolo", não é mera convenção destituída de conteúdo. Para Marx, o ouro representado continua sendo a substância do papel-moeda: "Ao circularem realmente em lugar da quantia de ouro de mesma denominação, governam seu movimento apenas as leis do curso do dinheiro. Uma lei específica da circulação do papel só pode originar-se da sua função de representar o ouro. Tal lei existe e diz que a

\footnotetext{
69 "O nome de uma coisa é extrínseco às suas propriedades. [...] todo vestígio de relação de valor desaparece dos nomes das moedas" (Marx 2002, p.128).

70 “[...] o ouro mesmo, seja em moeda seja em barras, pode tornar-se signo de valor metálico maior ou menor que o seu próprio, compreende-se que eventualmente notas de banco conversíveis em circulação compartam da mesma sorte" (Marx 1984b, p.73).
} 
emissão de papel-moeda tem de limitar-se à quantidade de ouro (ou, se for o caso, de prata) que realmente circularia se não fosse substituída por símbolos" (Marx 2002, p.154); ou ainda melhor: “O papel-moeda só é símbolo de valor por representar quantidade de ouro" (idem, p.155 - ênfase nossa). Este é o ponto central aqui: Marx pensa o papel-moeda como símbolo e não propriamente como signo, ainda que em alemão empregue o termo Wertzeichen. Para Marx, como vemos, deve existir uma "sombra de ouro", o que se configura como motivo para afirmarmos que ele diz "signo" quando de fato quer dizer "símbolo",71.

O padrão-ouro é, pois, a medida do sistema ${ }^{72}$. Se a oferta de papel-moeda está acima do que deveria ser, ele agora comprará menos ouro. Isto opera como se o ouro experimentasse uma alteração em sua função de padrão de preços; os valores se expressarão em maior quantidade de papel-moeda, ou seja, seus preços subirão. Dito de outra forma: Para Marx, a oferta correta de símbolos é dada pela necessidade de ouro que deveria circular. Os símbolos substituem o que o ouro faria.

Revela-se, pois, a tensão existente dentro da unidade entre seu modo aparente de ser (sua função) e seu modo efetivo de ser (como metal). O que revela justamente a tensão entre particular (seu modo de ser específico) e universal (seu modo social, funcionante, de ser). É, portanto, um ser unitário cindido em contrários. Sua matéria natural está em conflito contínuo com sua função social. Esta é a chave teórica para entendermos a origem lógica da moeda enquanto símbolo de sua substância e, posteriormente, para a necessidade do dinheiro inconversível. Como veremos, a forma dinheiro inconversível é a forma que soluciona esse conflito entre matéria e função do dinheiro.

Uma coisa não pode ser o seu próprio símbolo. Mas com o ouro parece que sim: peças de ouro menos nobres tornam-se símbolos de peças mais nobres e pesadas. Assim, sobre o ouro também atua esta tensão, entre ser e não-ser símbolo: por um lado o "ouro se transforma em símbolo de si mesmo, e por outro lado, não pode ser símbolo de si

\footnotetext{
${ }^{71}$ A forma que realiza esta passagem do dinheiro como símbolo ao dinheiro como signo é o dinheiro inconversível. O item 3.2.7 a seguir melhor qualificará a distinção operada por Hegel entre estas duas noções.

72 "Se o papel ultrapassa sua medida - a quantidade de moedas de ouro de igual nome que poderia circular -, expõe-se ao descrédito geral, mas ainda assim representa a quantidade de ouro determinada pelas leis imanentes do mundo das mercadorias, portanto, só a quantidade de ouro suscetível de ser representada" (Marx 2002, p.155 - ênfases nossas).
} 
mesmo" (Marx 1982, p.84). Enquanto houver esta separação entre ser efetivo e ser funcional, a tensão entre ser e não-ser símbolo persistirá. O processo somente se encerra quando o caráter monetário se torna independente da perda do seu conteúdo metálico. $\mathrm{O}$ símbolo de valor não pode ter valor intrínseco; o símbolo de valor não deve ter valor algum. O símbolo, como ainda veremos, tornar-se-á signo. No papel-moeda a cisão entre conteúdo metálico e conteúdo funcional (nominal) tornou-se quase absoluta. Se na origem não havia cisão alguma, pois o ouro ainda não se desgastara, agora, a cisão é levada quase ao seu limite. As denominações monetárias passam, então, a existir fora de suas substâncias.

Todavia, se Marx tivesse vivido para experimentar o papel-moeda totalmente inconversível, ele veria que o papel-moeda conversível de que tratou não era de fato o caso limite da separação entre conteúdo e função do dinheiro. O dinheiro inconversível do pós-1973 certamente é o caso mais absoluto da cisão tendencial já apontada por Marx no século XIX. Com o dinheiro inconversível do padrão dólar puro, o dinheiro como objeto se adéqua ao seu conceito, é efetivamente o que já era essencialmente, pura forma - ainda que "sua aparência de mercadoria dissimul[e] assim sua essência formal" (Paulani 1991, p.144).

\subsubsection{A Moeda Enquanto Moeda Inconversível: Sua Necessidade Lógica}

A moeda inconversível está pressuposta nos esquemas de Marx, cabe agora a sua posição. Estava pressuposta porque estava com todas as suas determinações, ainda que não tivesse a determinação posição. Sabemos por Fausto (1987a) que tanto a Hegel quanto a Marx um conceito pode estar com todas as suas determinações e ainda assim não estar posto. Se em Marx o dinheiro inconversível está pressuposto, sua necessidade objetiva foi posta em 1971. Cabe agora pô-la no nível do discurso.

Em um texto pouco conhecido, Marx deixa claro que a essência do dinheiro é ser uma abstração: 
"The personal mode of existence of money as money ... corresponds the more to the essence of money, the more abstract it is, ... the greater the inverse relationship of its value as money to the exchange-value or money value of the material in which it exists" (Marx 1844 - ênfase nossa) $)^{73}$

$\mathrm{O}$ argumento aqui não é o de que falta ao Capítulo 3 do Volume I de $O$ Capital a posição objetiva do dinheiro inconversível, senão a posição determinação mesma. Não é que o dinheiro inconversível enquanto realidade efetiva [Wirklichkeit] está ausente para Marx, mas enquanto realidade $[\text { Wirklich }]^{74}$ mesmo. Se para o marxismo é a posição objetiva (efetividade) que regula a posição determinação (categoria), cabe agora, pelo trabalho do negativo, introduzir o dinheiro inconversível nos esquemas marxistas enquanto categoria, essência. Queremos passar do fenômeno à essência, da realidade efetiva à realidade, para assim mostrar sua necessidade lógica. Dessa forma, o dinheiro inconversível evidenciar-se-á como uma nova determinação que adéqua o dinheiro ao seu próprio conceito, e o dinheiro inconversível mundial (padrão dólar puro) como sua existência mais congruente. $\mathbf{O}$ dinheiro inconversível é uma determinação nova, é uma forma particular do dinheiro, sendo o dólar mundial pós-1971 seu modo de existência, seu uso, mais adequado. O dinheiro inconversível não está presente em Marx como posição determinação, não se encontra no conceito de dinheiro - afinal nem existia no século XIX como posição objetiva. Ou seja, o dinheiro inconversível, em $\boldsymbol{O}$

Capital, não existe enquanto categoria, como realidade. Como ele agora existe enquanto fenômeno, realidade efetiva, cabe a esta dissertação pô-lo enquanto essência. O que, em suma, é fazer o conceito de dinheiro mover-se pelo trabalho do negativo. Portanto, à pergunta "estaria o dinheiro inconversível compreendido da Seção I do Volume I de O Capital?", deveríamos responder: “sim e não” ou "sim-não"; está e nãoestá. Está pressuposto, cabe agora pô-lo realmente.

\footnotetext{
73 Trecho citado a partir de um texto de Marx de 1844 intitulado "Comentário sobre os Elementos de Economia Política de James Mill”, que está disponível em: http://www.marxists.org/archive/marx/ works/1844/james-mill/index.htm, e que foi primeiramente utilizado por Bryan e Rafferty (2007, p.152).

${ }^{74}$ Seguindo Paulani (1991, p.142 e 163) temos a seguinte diferenciação em Hegel. A realidade [Wirklich] diz respeito à essência, à existência como essência, à categoria, à posição determinação no nível do ser. Aqui a realidade é realidade somente das determinações e, portanto, irrealiade da coisa. Isto é, a coisa é real mas não efetivamente real. A realidade efetiva [Wirklichkeit], por sua vez, concerne ao fenômeno, à posição objetiva, à efetividade, aparecendo enquanto realidade. É o momento da aparição da essência e a unidade imediata da essência e da existência. O ser posto do fenômeno é o ser com todas as suas determinações mais a posição, onde a coisa somente vai existir quando se suprimir na aparência, quando for posta. Em suma, a realidade efetiva é a realidade posta.
} 
Fausto (1987a, p.169-170) diz que o ouro como dinheiro é a apropriação pela forma de uma materialidade que lhe é adequada ${ }^{75}$. Porém, acrescentemos uma correção: é adequada mas ao mesmo tempo também inadequada, pois nesta matéria a forma dinheiro ainda encontra atritos entre sua materialidade e sua funcionalidade. É só como forma pura, dinheiro inconversível, que a forma dinheiro se torna adequada ao seu conceito. Assim sendo, não é a matéria que tem de estar em conformidade com a forma, mas sim que a forma deve estar adequada ao seu próprio conceito. O ouro é e não-é matéria congruente ao equivalente geral. É adequada por conta de todas as características naturais da matéria ouro, contudo concomitantemente inadequada, pois essencialmente à forma dinheiro não lhe conforma nenhuma matéria ${ }^{76}$.

Entendemos aqui que a forma mercadoria e as formas I, II, III e IV representam a gênese da forma dinheiro ${ }^{77}$. A forma dinheiro inconversível, por seu turno, diz respeito ao desenvolvimento da forma dinheiro. Não se trata, porém, de um desenvolvimento histórico, mas primordialmente lógico: o dinheiro inconversível é a forma lógica que supera as inadequações da forma dinheiro com materialidade no ouro ${ }^{78}$. Há, portanto, uma necessidade lógica de passarmos à forma dinheiro inconversível. Necessidade dialética. Assim entendido, a decisão do governo de Nixon em pôr fím ao padrão-ouro está longe de ser mero resultado de um capricho humano ou de uma contingência histórica. Este movimento não é senão a realização necessária da essência do dinheiro. Tratar o dinheiro que hoje temos como fruto contingente da história implica o fortalecimento da tese convencionalista do dinheiro. A solução "historicista"

\footnotetext{
${ }^{75}$ Deixemos claro que apesar de usarmos muito as análises de Fausto, este autor em momento algum de seus vários textos se preocupa com a forma dinheiro inconversível. Nossa intenção é, portanto, fazer uso do discurso dialético rigoroso de Fausto para apreendermos adequadamente nosso objeto de estudo.

76 "[...] the essence of money is socio-economic , not natural" (Williams 2000, p.447).

${ }^{77}$ Marx afirma reiteradamente no Capítulo 1 do Volume I de $O$ Capital que é a forma relativa que se desenvolve, levando consigo a sua antítese, a forma equivalente. Ou seja, a forma equivalente geral é resultado do desenvolvimento da forma relativa. A forma equivalente é passiva. Contudo, na forma dinheiro inconversível enquanto equivalente universal é a forma equivalente que passa a comandar o desenvolvimento da forma relativa. Exatamente em oposição ao que ocorria no desenvolvimento lógico precedente. Isto é: com o dinheiro inconversível, a forma equivalente perde sua passividade que lhe fora constituinte.

Nosso estudo aponta para o fato de que a apresentação lógica proposta por MarX no século XIX para as formas capitalistas não dá mais conta do seu objeto. Contudo, ficará como tarefa de um estudo futuro saber como re-escrever a apresentação dessas formas, de tal maneira a adequá-la à sua nova realidade.

${ }^{78} \mathrm{O}$ fato de não haver modo algum de tornar verdadeira e/ou existente a relação entre a forma dinheiro e um substrato revela o caráter metafísico, supra-sensível, do valor; e que ele é, antes de tudo, uma relação social (Paulani 1991, p.145).
} 
é uma que evita as contradições do objeto e não diferencia posição de pressuposição ${ }^{79}$.

A congruência entre a forma e a matéria ouro se revela, assim, como não-congruência.

A verdade da adequação entre forma e matéria é sua inadequação; sua verdade é sua negação. O sistema se corrompe por esta contradição, cuja origem é a própria identidade. Isto é, da identidade entre forma e matéria emergiu a diferença e, mais do que diferença, contradição. A congruência se interverte em incongruência pela sua própria efetivação. A ruptura vem do interior. A tendência da forma é sua verdade.

O dinheiro inconversível está pressuposto em $O$ Capital; é aí uma possibilidade: "Convertibility, therefore- legal or not - remains a requirement of every kind of money whose title makes it a value-symbol, i.e. which equates it as a quantity with a third commodity. The equation already includes the antithesis, the possibility of nonequivalence; convertibility includes its opposite, inconvertibility" (Marx 1973, p.134). Contudo, não se trata aqui de mostrar que o possível enquanto possível por ser possível se põe como necessário, senão que o possível enquanto puro possível é impossível que ele se põe como necessário. É a supressão da possibilidade que permite a passagem à existência, ao ser. Se o possível enquanto puro possível for possível, não haverá efetividade. A prova da necessidade lógica do dinheiro inconversível segue um argumento negativo: "Para Hegel, não é porque o possível enquanto possível é possível que ele se põe como necessário. É porque o possível enquanto puro possível é impossível que ele se põe como necessário. De onde a preferência de Hegel pela versão negativa do argumento ... que deve evidentemente perder seu caráter de prova por absurdo para se transformar em prova pela negação (através do 'absurdo', se diria)" (Fausto 1987b, p.163). Ou, dito de outra maneira: as sucessivas formas do valor que nos são apresentadas põem o que a forma anterior pressupunha; e o dinheiro inconversível não escapa a isso, já que ele põe o que a forma dinheiro conversível pressupõe. Se Fausto (1997, p.65,70-71) diz claramente que o dinheiro é equivalente universal estável

\footnotetext{
${ }^{79}$ Os dizeres de Cacherdi nos fornecem um bom exemplo do que exatamente aqui queremos evitar, a solução historicista: "[T]he convertibility of paper money is not a necessary condition for it to be a symbol of social value, a symbolic measure of value. The fact that, originally, money as a measure of value had an intrinsic value is a feature typical of a historical period, not an absolutely necessary feature, as the introduction of convertible paper money shows. In the same way, convertibility is a feature of another historical period and not an indispensable prerequisite for money to function as a symbol of value" (Carchedi 1991, p.165).
} 
graças ao caráter adequado da matéria em que se encarna o valor, aqui nossa tese é outra: o dinheiro enquanto ouro é adequação posta (pois retira a instabilidade da forma III) e inadequação pressuposta (pois tem um conflito entre sua função social e sua materialidade particular, o ouro). É por isso que enfatizamos que o dinheiro inconversível é a posição do que está pressuposto no dinheiro conversível. A posição da forma pura resolve a contradição entre forma e matéria constitutiva do dinheiro, tornando-o adequado ao seu conceito. O dinheiro inconversível põe a descoberto que a "estabilidade" da forma dinheiro conversível é em verdade uma estabilidade aparente. Como veremos ao analisarmos o dólar pós-1971, a universalidade enquanto dinheiro nunca é estável, sendo esta inquietude da forma a que faz mover-se como conceito.

O dinheiro inconversível é e não-é a forma dinheiro presente em $O$ Capital. É, porque parte dela. Não é, porque a nega. Nega e conserva. Se fosse só um desdobramento historicista, então somente haveria conservação. Mas, como mostramos, além de conservação há uma negação. A dialética da forma do valor, ou seja, da gênese do dinheiro, opera a passagem da posição ideal a uma posição real da forma na matéria (Fausto 1997, p.39). Agora, após o que vimos, poderíamos completar esta asserção dizendo que se a gênese do dinheiro é a posição real da forma na matéria, o desenvolvimento do dinheiro é a expulsão da matéria pela forma. Desse modo, o desenvolvimento do dinheiro operaria uma verdadeira Aufhebung (negaçãoconservação) de sua gênese. Em outras palavras: o dinheiro inconversível revela que o desenvolvimento da forma dinheiro é na realidade uma inter-versão de sua gênese. Enquanto a gênese trata de mostrar que forma e matéria são adequadas, o desenvolvimento trata de mostrar que elas são, ao contrário, inadequadas.

O sistema lógico apresentado por Marx tem uma mensagem central clara: a progressiva autonomização do valor em relação ao valor-de-uso, e do trabalho abstrato em relação ao trabalho concreto. Que é justamente, como vimos no primeiro capítulo, a cisão da modernidade que Marx tomou de Hegel. Autonomização aqui entendida como introdução de novas camada mediadoras entre dois pólos que constituem o mesmo objeto, a mercadoria. É por isso que Marx mantém a noção hegeliana de que a modernidade é um momento para o qual o universal está cindido em relação aos particulares. Reconhecer que o dinheiro inconversível é adequado ao capitalismo 
implica reconhecer a negatividade que perpassa forma e matéria, valor e valor-de-uso, trabalho abstrato e trabalho concreto.

Quando a forma expulsa a matéria da qual emergiu, o sentido da pressuposição do ouro pelo dinheiro mudou, já que deixou de ser pressuposição posta e interior ao sistema de significações para ser simplesmente pressuposta e exterior ao sistema de significações. Ou, alternativamente: o dinheiro inconversível faz do ouro não mais pressuposição posta, mas sim pressuposição externa.

Se o capital interioriza suas pressuposições, produz o que pressupõe, cria o que é pré-condição para si mesmo, ao mostrar-se em seu processo contínuo de acumulação (isto é, quando passamos à Seção VII do Livro I de $O$ Capital) e, por isso mesmo, se autonomiza em relação a elas, pois as recria constantemente como pressuposições (Fausto 1987b, p.283) - que é exatamente o que caracteriza o capital como sujeito (em sentido hegeliano) -, agora se vê algo diferente: a forma dinheiro inconversível é mais autônoma não porque internaliza suas pressuposições, mas sim porque as externaliza, as expulsa do sistema de significações internas. E faz isso ao recolocar essa pressuposição externa como sua nova aparência de apego às mercadorias. Nada mais adequado ao valor-de-troca autonomizado em relação às suas pressuposições. Se antes o dinheiro representava a autonomia enquanto auto-posição das pressuposições, agora sua maior autonomia é exteriorização das pressuposições. A apresentação dialética é uma “dedução" cujos "princípios” são negados pelas conseqüências (Fausto 1987b, p.277), e a forma dinheiro aqui analisada não foge desta asserção. O dinheiro enquanto dinheiro inconversível nega duplamente seus princípios: primeiro nega a matéria conservando-a, para depois negá-la com expulsão ${ }^{80}$. O dinheiro conserva esses dois princípios duplamente negados. A maior autonomia se dá assim através de uma nova negação das pressuposições. O trabalho também parece ser a matéria adequada à forma capital. Porem, tomar isto como certo é positivar uma relação que em verdade é contraditória. No caso do dinheiro inconversível ocorre o mesmo processo: tomar a matéria como adequada à forma dinheiro é positivar uma relação que em verdade é contraditória.

\footnotetext{
${ }^{80} \mathrm{Na}$ primeira negação, quando o papel-moeda substitui o outro, a matéria é negada mas conservada, e conservada mais precisamente como aparência (Paulani 1991). Na segunda negação, a forma nega novamente a matéria, mas desta vez não mais a conserva. Resta, portanto, saber qual é a nova aparência da forma dinheiro inconversível. $\mathrm{O}$ item seguinte discute este ponto.
} 


\subsubsection{A Moeda Enquanto Moeda Inconversível: Auto-Referência, Convencionalismo e Fetichismo}

A passagem do dinheiro conversível ao dinheiro inconversível, que não promete nada além de si mesmo, evidencia que esta última forma determina o seu valor e o que ela significa como signo através de uma auto-referência (Rotman 1987, p.5). A moeda inconversível, portanto, apresenta uma característica específica de auto-referencialidade. Porém, não seriam universalidade e auto-referencialidade duas faces do mesmo objeto? Não seria o universal sempre auto-referente?

Marx, no Capítulo 3 do Volume I de $O$ Capital, nos alertou para o fato de que a substituição das moedas de ouro por notas de papel induzia a ciência a apreender o dinheiro como "puro signo" ou mesmo um "produto abstrato da reflexão" - afinal de contas o padrão dólar puro denuncia de alguma forma que o dinheiro tem uma dimensão metafísica ainda mais forte (Paulani 1991, p.146). A preocupação de Fausto (1987b, p.61) é a de que tal processo reforça o caráter de aparente convenção das formas monetárias, onde figura o convencionalismo como uma "ligação sem necessidade". Uma de nossas tarefas foi, portanto, mostrar a necessidade lógica do dinheiro inconversível, justamente a fim de evitarmos ao máximo qualquer recurso convencionalista.

O dinheiro inconversível diz respeito a um nível mais elevado de autonomização do valor. Existiria, desse modo, um fetichismo próprio a ele? Tomando por base o fato de que esta nova posição da forma na matéria expulsa a matéria, diríamos que tratar a matéria como adequada à forma é cair em fetichismo, cujo complemento é a tese convencionalista de que seria a forma dinheiro inconversível pura convenção, pura arbitrariedade. A tentação para cairmos em explicações convencionalistas não é pouca. Mesmo Foley (1986, p.23-24) chega a afirmar que quando o dinheiro é inconversível "the general equivalent is an abstract unit of account". Em outras palavras, ele diz que quando o dinheiro torna-se inconversível, a forma equivalente é preenchida por uma convenção, uma unidade abstrata de conta. 
Primeiro expliquemos o que entendemos por fetiche e convenção. Seguindo Fausto (1997, p.76 e subs.) temos dois pólos antinômicos:

(a) Fetichismo: é o anti-convencionalismo abstrato, pois supõe que a matéria que serve de suporte à forma é naturalmente a forma. É, portanto, a ilusão naturalista de supor que o conteúdo é natural. Toma o suporte por forma;

(b) Convencionalismo: é supor que a matéria da forma é qualquer. É, assim, a ilusão da ausência de conteúdo ao supor que as relações sociais são produtos arbitrários da reflexão dos homens.

Se o fetichismo da modernidade é a "projeção descendente" do abstrato social ao abstrato natural (Fausto 1987b, p.62), a forma dinheiro inconversível é, neste sentido, um exemplo excelente de uma abstração social em sua máxima realidade. Assim, essa forma mais bem acabada do dinheiro leva o seu fetichismo ao extremo, para o qual os rastros de sua gênese tornam-se ainda mais camuflados.

Maior autonomia do dinheiro inconversível que tampouco se fez sem um movimento ideológico particular. Se a matéria foi negada pela forma no sistema, o processo ideológico de "bloqueio das significações" (Fausto 1987b, p.299) inverte no plano das representações os termos postos e negados. Por mais que o dinheiro esteja de fato apartado de uma matéria que lhe confira valor ou "estabilidade", a ideologia faz o contrário ao negar o que está posto (a inconversibilidade da pura forma) e ao positivar o que está negado (a matéria). Esse processo de bloqueio operado pela ideologia é justamente o que mais trabalha a favor da inversão. Ou seja, a ideologia opera uma inversão para que a inversão mesma não apareça como tal. Se o dinheiro quer se afirmar como pura forma, a ideologia o apresenta como pura matéria. Dessa maneira, o dinheiro inconversível como pura forma é mais eficazmente posto como o que é quando se apresenta como o que não-é, como o contrário de si mesmo. Para se pôr como o que é, tem que se afirmar como o que não é. O Estado neste caso é absolutamente necessário, pois é o "guardião da identidade" 81 .

\footnotetext{
${ }^{81}$ Este termo é apresentado por Fausto (1987b, p.301) para introduzir a necessidade lógica da ideologia e do Estado no capitalismo. O empregamos por considerar que no caso em questão o termo também se adéqua bem.
} 
O ilusório objetivo é que a presença pressuposta é apresentada como se estivesse posta. A ilusão, fruto também da gramática do entendimento, reside na indiferenciação entre posição e pressuposição, já que o pensar representativo só trabalha com termos positivados, plenamente constituídos. Assim, o processo de constituição da forma monetária pura se reduz a uma identidade "garantida" na prática por um carimbo do Federal Reserve norte-americano. Sem o Estado, a forma inconversível do dinheiro não teria lugar, pois sua formação contraditória ou ficaria a descoberto ou nem mesmo se efetivaria. Ele só é possível e efetivo como unidade contraditória por ter a figura estatal como "garantidora" desta identidade. O Estado "garante o funcionamento de relações que não podem ser abandonadas a elas mesmas, mesmo em circunstâncias normais, justamente porque elas são contraditórias" (Fausto 1987b, p.311). E faz isso hipostasiando a aparência. A mistificação é a apresentação do fundo pressuposto como se ainda estivesse posto.

Ainda assim, mesmo tendo o aparato estatal como bastião da identidade, as crises financeiras e monetárias vêm a colocar em dúvida a própria identidade entre forma e matéria - ainda que não consigam chegar ao ponto de revelar socialmente que forma e matéria são contraditórias. A crise as coloca simplesmente como diferenças. Desse modo, se em um momento (o do Estado) é a identidade que oculta a contradição, no outro (o da crise) é a diferença que oculta a contradição. A contradição mesma entre forma e matéria, constitutiva do dinheiro, não aparece socialmente. Ela se mantém oculta ora sob a identidade ora sob a diferença.

O dinheiro inconversível traz consigo duas possibilidades de ilusão: (a) achar que a matéria sempre foi uma pressuposição externa, o que inevitavelmente levaria a uma teoria convencionalista do dinheiro; (b) achar que a matéria continua sendo uma pressuposição interna, o que seria evitar os novos problemas que o dinheiro implica. Assim, dois tipos de autores evitam esta discussão: (a) aqueles que acreditam que a inconversibilidade do dinheiro é ou uma ilusão ou uma determinação temporária ${ }^{82}$; (b) aqueles que acreditam que o dinheiro nunca foi um dinheiro-mercadoria, sendo pura convenção ${ }^{83}$ - teóricos estes que tampouco conseguem explicar como o dinheiro como pura convenção mede os valores das mercadorias.

\footnotetext{
${ }^{82}$ Ver Saad-Filho (2002, p.145 n.26).

${ }^{83}$ Ver Saad-Filho (2002, p.145 n.27).
} 
A figura a seguir mostra a seqüência das formas que aqui analisamos (as formas simples e total foram ocultadas), onde figuram por nossa conta duas novas formas: a "forma dinheiro conversível" e a "forma dinheiro inconversível".

Figura 3.1: A Sucessão das Formas do Valor

(f.r. $=$ forma relativa $;$ f.e. $=$ forma equivalente $)$
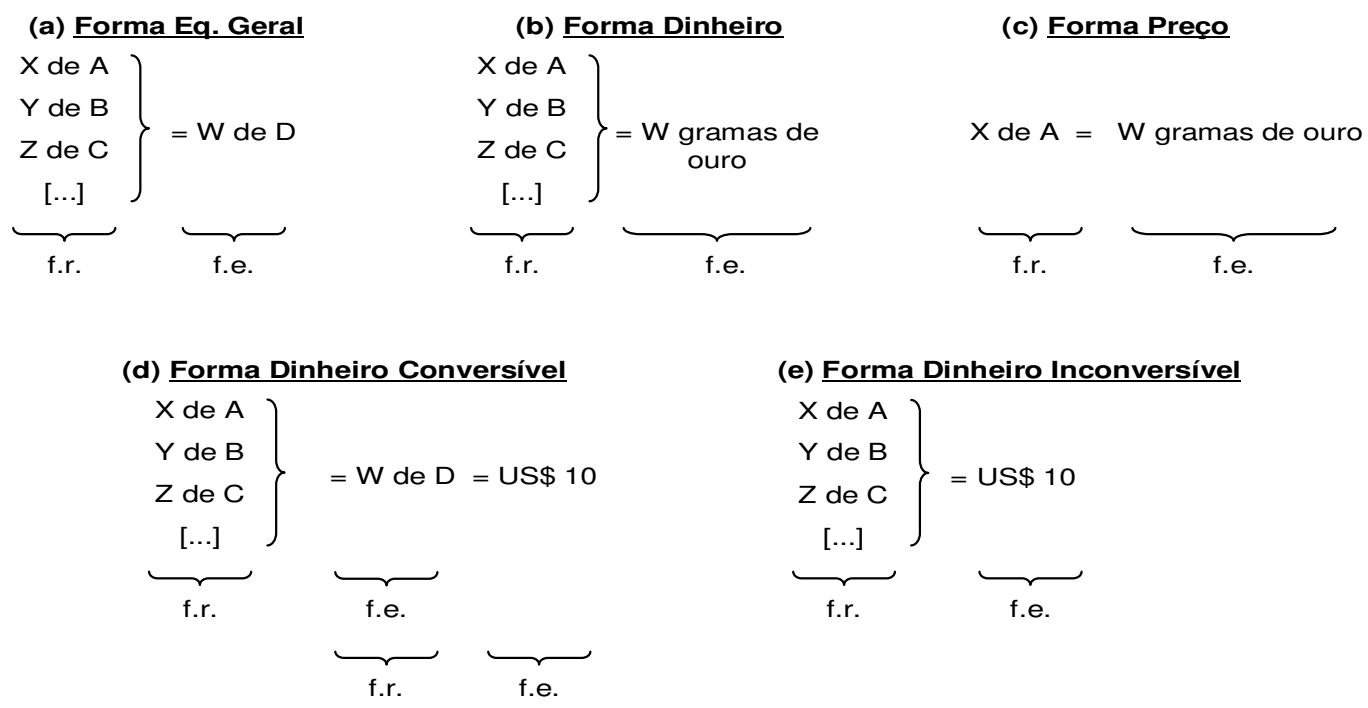

(e) Forma Dinheiro Inconversível

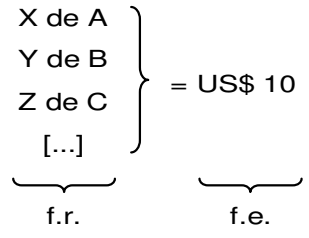

As formas (a), (b) e (c) já são conhecidas e não nos trazem problemas. A questão, portanto, está nas formas (d) e (e). Na "forma dinheiro conversível" a parcela "W de D” ocupa simultaneamente duas posições lógicas, a de forma equivalente e a de forma relativa, que é resultado da dupla relação entre as várias mercadorias e o equivalente geral e outra entre o equivalente geral e uma denominação monetária. Tal inadequação só pode ser resolvida em uma outra forma, a do dinheiro inconversível, para a qual a exclusão do valor-de-uso como matéria do equivalente geral elimina a contradição advinda de uma mesma mercadoria que ocupa duas funções lógicas excludentes.

Entretanto, esta solução nos traz um problema adicional. Já sabemos que a forma relativa figura com seu valor enquanto que a forma equivalente figura com seu valor-deuso, donde emerge justamente a expressão do valor através do seu contrário, o valor-de- 
uso $^{84}$. Este é o mecanismo lógico que explicita que a origem lógica do fetichismo (a expressão do que é social, o valor, por meio do que é natural, o valor-de-uso) reside na própria expressão do valor. Só que na última forma, a do dinheiro inconversível, não há mais valor-de-uso do lado direito da equação; isto é, a forma equivalente figura aí não mais como matéria para expressão do valor de outra mercadoria. Neste caso só permanece a arbitrariedade do padrão de preços e da unidade de conta imposta por convenção. Como, então, fica a explicação do fetichismo quando o seu mecanismo de origem (expressão do valor através do valor-de-uso) não está mais presente na forma dinheiro inconversível? Ainda se pode falar de fetichismo quando o valor-deuso desapareceu do lado da forma equivalente? Marx afirmava que o valor para ser expresso devia ser posto no valor-de-uso de outra mercadoria; mas quando o dinheiro é inconversível, quem assume essa função de valor-de-uso? Um valor-de-uso formal?

Fausto (1997, p.78) diz que "o preço da desconvencionalização é a fetichização", no sentido de que conforme se caminha na apresentação das formas do valor, saímos cada vez mais das teses convencionalistas sobre preços e dinheiro para cairmos paulatinamente na naturalização das formas sociais. Contudo, pelo que vemos do desenvolver lógico do dinheiro, a forma inconversível parece apresentar ao mesmo tempo essas duas ilusões objetivas. Se atualmente se confunde ainda suporte com forma, não é menos verdade que a sociedade toma esta forma pura por simples convenção. Fausto está correto quando afirma isto do ponto de vista da apresentação lógica das formas, mas do ponto de vista dos agentes ambas as ilusões caminham em graus crescentes.

A gênese do dinheiro mostra que esta forma não é uma criação arbitrária através de leis ou através do Estado, porém podemos observar que ao se progredir na apresentação lógica do dinheiro se faz necessário cada vez mais pôr o Estado. Quanto mais abstrata se torna a riqueza mais mecanismos concretos (inefetivos) são criados para controlá-la, sendo que tais tentativas de apreendê-la concretamente parecem de fato

\footnotetext{
${ }^{84}$ Se perguntássemos a uma mercadoria diante de outra o que ela vê, ela responderia: "Vejo outra mercadoria, e nela me vejo também". É análogo ao que se passa ao perguntarmos a uma pessoa o que ela vê quando diante de um espelho; ela deveria então responder que vê a si mesma no espelho e que também vê um espelho. Quando Hegel diz que sua filosofia é especulativa, é a esta analogia com um "jogo de espelhos" que ele se refere.
} 
impulsioná-la cada vez mais a se tornar um poder abstrato. Quanto mais abstrato se tornam as formas monetárias, mais mediações jurídicas são necessárias para efetivá-las.

\subsubsection{O Problema da Moeda Inconversível como Medida dos Valores}

Neste item investigamos a moeda enquanto medida dos valores, que é analogamente um problema de determinação do valor da moeda. No item seguinte, nossa preocupação será com a moeda enquanto meio-de-circulação, que é um problema de representação do valor. Ambos são "problemas" porque ainda não está claro o que ocorre com tais determinações quando o dinheiro passa a ser dinheiro inconversível, desgarrado completamente de qualquer matéria ${ }^{85}$. Ou seja, o dinheiro inconversível traz dois problemas teóricos para o dinheiro enquanto moeda: um de determinação do valor da moeda e outro da representação do valor através de símbolos. Ambas as questões são pertinentes ao dinheiro enquanto moeda, e não ao dinheiro enquanto dinheiro.

Como visto previamente, temos dois problemas distintos: se um par de sapatos custa 100 dólares ou 1000 dólares constitui-se uma questão diferente de como se forma o preço, seja ele qual for. O nosso problema fundamental a ser aqui investigado diz respeito mais ao segundo questionamento, ou seja, sobre como passar de valores a preços sob a forma da moeda inconversível. Não estamos preocupados com o nível absoluto dos preços, mas sim em como eles são determinados a partir dos valores, considerando a primeira determinação da moeda, a medida dos valores ${ }^{86}$. "While Marx allows that in its functions as currency the state may replace gold with paper, he insists that in its function as measure, commodity money cannot be replaced, even if it may so function 'ideally', namely, in its absence (Arthur 2005, p.115).

Para o dinheiro conversível, papel-moeda lastreado em metal precioso, há uma "sombra de ouro", que em termos dialéticos seria exatamente a pressuposição

\footnotetext{
${ }^{85}$ Há aqueles que discordam de uma necessidade lógica da primeira forma dinheiro ter tido algo físico como sua matéria: "Commodity money may not need to be a physical commodity at all. In Capital Marx did indeed equate money with gold (although in other work he described bullionism as educated superstition). But we do not have to take gold as the theoretical commodity basis to capitalist money: it was merely the particular dominant commodity money of the nineteenth century" (Bryan e Rafferty 2007, p.152).

86 "O dinheiro permite a expressão quantitativa do valor, mas ele mesmo não é expresso quantitativamente. Está aí toda a dificuldade” (Fausto 1997, p.54)
} 
posta que, para nós, é característica somente do padrão-ouro tradicional ou padrão dólar-ouro. Fausto (1997, p.92) assevera claramente que o dinheiro enquanto medidados-valores é ideal, mas ideal como representação imediata da matéria. Ou seja, ainda que o dinheiro aqui seja ideal, sua representação não aceita mediações para se chegar à matéria. Entretanto, quando o dinheiro perde tal matéria, como determinamos os preços? Como visto acima, fica claro que os preços são pré-condição da circulação monetária, e não o contrário. Assim sendo, como determinar os preços com o dinheiro inconversível e completamente desgarrado do ouro? "The real question is whether money must be a commodity in Marx's theory in its fundamental function as measure of value" (Moseley 2005, p.5). Como diz Arthur (2005, p.116), o problema do dinheiro inconversível enquanto medida dos valores não é só lógico nem só social, ele é ontológico.

De fato, Marx apontou a tendência da forma dinheiro em se tornar uma pura forma. Nos Grundrisse ele diz: "money owes its existence only to the tendency of exchange value to separate itself from the substance of commodities and to take on a pure form" (Marx 1973, p.160). Entretanto, na seqüência do mesmo texto Marx se mostra preso à realidade objetiva do padrão-ouro: "In the course of development, the exchange value of money can again exist separately from its matter, its substance, as in the case of paper money, without therefore giving up the privilege of this specific commodity, because the separated form of existence of exchange value must necessarily continue to take its denomination from the specific commodity" (Marx 1973, p.167). Ou seja, já nos seus rascunhos, e assim como ficará visível no Zur Kritik e em O Capital, Marx entende que a essência do dinheiro é puramente formal, ainda que ele se apresente através do ouro.

Sobre o ouro como dinheiro, Marx (1982, p.57) nos diz claramente que para este se tornar equivalente geral precisa ser um "valor variável", justamente por dever ser encarnação de tempo de trabalho social. Isto é evidente para o ouro e para o seu símbolo (que não tem valor), o papel-moeda. Mas, quando o papel perdeu o lastro em ouro, como pode este ser um "valor variável"? Ou melhor: que valor o papel-moeda inconversível encarna?

A primeira intuição que temos é a de que o dinheiro inconversível opera uma inversão de sua determinação de medida-dos-valores, já que em tal caso "money would not be a 
measure of value of commodities; on the contrary, its own value would be measured by the current requirements of circulation" (Hilferding 1981, p.56-57). O dinheiro, ao perder sua materialidade, passa de mensurador a mensurado ${ }^{87}$. O que, dito de outra forma, implicaria que o dinheiro enquanto medida dos valores nega a TQM, mas quando posto como dinheiro inconversível parece repor a validade da TQM. Assim sendo, "the function of value measurement seems to indicate that analysis of valueless money on the basis of commodity money reaches a theoretical impasse" (Lapavitsas 2000, p.634).

Vejamos agora as principais soluções que a literatura internacional apresenta para este problema lógico, e façamos as respectivas e devidas críticas a cada uma delas:

\section{(i) Foley e Carchedi:}

A solução apresentada por Carchedi (1991, p.165-166) e por Foley (1986, p.14) ${ }^{88}$ é a de que o valor do dinheiro inconversível passa a ser dado pelo valor que elas representam, isto é, pelo seu poder de compra: "The fact that money has no intrinsic value ... does not mean that paper and credit money are valueless. Their value is their purchasing power" (Carchedi 1991, p.166). O poder de compra do dinheiro é calculado dividindose a soma do valor novo criado (mais o valor dos meios de produção transferidos ao produto menos o valor destruído ou desperdiçado) pela quantidade total de dinheiro em circulação (moedas, papel-moeda e crédito).

Em suma, o que fornece o valor do dinheiro para estes autores é o valor produzido que está incorporado nas mercadorias e o volume de dinheiro em circulação. Mas não seria esta uma solução que contraria os dizeres de Marx de que "as mercadorias já entram na circulação com preço"? Ao que parece, até aqui, o solução foi retornar às teorias da TQM de Irving Fisher e Hume - que vimos no capítulo 2. Além do mais parece surgir uma confusão entre as determinações da moeda: "the total quantity of money serves as a

\footnotetext{
${ }^{87}$ Hilferding (1981, p.57) ainda continua: "A pure paper currency is, therefore, impossible as a permanent institution, because it would subject circulation to constant disturbances". Como veremos no Capítulo 4, usaremos o mercado de derivativos financeiros para estabelecer a ligação lógica entre o dinheiro inconversível e a formação de capital fictício própria a ele. Já adiantamos que os derivativos são justamente a resposta privada ao fim do regime regulador de Bretton Woods e à crescente instabilidade monetária trazida pelo padrão dólar-puro e pelas taxas cambiais flexíveis.

${ }^{88}$ Nelson (2005) e Bellofiore (2005) também compartilham desta solução.
} 
measure of value and thus as a means of circulation of all commodities" (Carchedi 1991, p.166), afinal ambas as determinações passariam a depender da quantidade de dinheiro circulante ${ }^{89}$.

Foley (1986, p.14-15,21) deduz o valor do dinheiro dividindo o valor novo criado (mensurado em horas de trabalho) pelo valor criado expresso em unidades monetárias (dólares). "This ratio we shall cal the value of money because it tells us how much labor time the monetary unit represents" (idem, p.15). O inverso do "valor do dinheiro" é a “expressão monetária do valor" (MELT, monetary expression of labor time), a qual nos diz quanto de valor em unidades monetárias 1 hora de trabalho cria ${ }^{90}$.

Entretanto, estas asseverações são válidas para qualquer forma do dinheiro, seja dinheiro metálico, dinheiro papel-moeda ou mesmo dinheiro inconversível. Não faz diferença para a determinação da MELT se o dinheiro é ou não assentado sobre o ouro. Ou seja, isto não é uma real solução, pois aqui o problema real do dinheiro inconversível não está posto. Em verdade podemos calcular a MELT, ou o valor do dinheiro, em qualquer sistema monetário, pois é um cálculo ex post sempre válido, e não uma teoria sobre a determinação do valor do dinheiro. Dito de outro modo, o que temos aqui é uma fórmula de cálculo universalmente válida a posteriori, mas que não serve como explicação dos determinantes do valor do dinheiro inconversível.

O próprio proponente sabe disto e chega a dizer explicitamente que como a MELT é calculada dividindo-se o valor adicionado em termos monetários pelo trabalho socialmente utilizado, esta estimativa empírica não é uma explicação teórica do que de fato a determina, pois dessa forma a MELT dependeria do valor adicionado e, portanto, não poderia ser usada para determinar o valor adicionado (ou os preços das mercadorias), já que dessa maneira cairíamos em um raciocínio circular (Foley $2005)^{91}$.

\footnotetext{
${ }^{89}$ Saros (2007) segue na mesma linha: "Just as convertible paper represents a claim to gold, inconvertible paper represents a claim to commodities to be purchased" (p.409). Assim, "[t]he fiat money price-form is thus a fractional reflection of the aggregate value of commodity in circulation" (p.410). O valor do dinheiro inconversível, para Saros, é daterminado pela sua quantidade em circulação e pelo valor das mercadorias que representa - o que o aproxima muito da solução de Moseley (2004).

${ }^{90}$ Ver Foley (1986, p.15) para a diferenciação entre "valor do dinheiro" e o "inverso da taxa de salário", definições que não devem ser tomadas como sinônimos.

${ }^{91}$ Neste mesmo texto Foley (2005, p.38-39), que é seguido por Reuten (2005), invoca uma interpretação da "forma valor" para explicar a determinação dos preços. Tal teoria afirma que o trabalho abstrato não
} 
Foley (1986, p.24) chega até o ponto de dar uma solução historicista para um problema lógico. Diz ele que em um sistema monetário em que o equivalente geral é uma unidade abstrata de conta, como quando o dólar não tem legal ou convencionalmente um equivalente definido em ouro, "the value of money is determined historically, by the pricing decisions of commodity producers themselves" (idem). Porém, tal explicação é inaceitável, pois confunde os discursos lógico e histórico.

Além do mais, como lembra Saad-Filho (2002, p.97), tais mediações entre a determinação do valor-de-troca do dinheiro não implicam que seja errôneo pôr, ex post, um equivalente monetário do trabalho. Entretanto, isto tende a unificar diferentes níveis de abstração, obscurecendo os elementos contraditórios de sua determinação ${ }^{92}$.

Acima de tudo, esta solução para nós é uma recaída no argumento de Hume, para o qual se colocam mercadorias de um lado e o dinheiro circulante de outro, daí derivando o valor do dinheiro por um simples raciocínio proporcional entre ambos estes compartimentos. Marx no Zur Kritik já havia negado a validade deste raciocínio por pressupor que circulam mercadorias sem preço. Ou seja, para Hume o preço é formado na união do "lado real" com o "lado monetário". A solução de Foley e Carchedi parece, assim como mostramos, voltar a este argumento não-marxista.

\section{(ii) Lapavitsas e Saad-Filho}

O argumento central de Lapavitsas (2000) e Saad-Filho (2002, p.98-99) é o de que o problema do dinheiro inconversível enquanto medida dos valores deixa de ser um problema efetivo quando passamos ao âmbito da concorrência dos capitais (isto é, no âmbito dos preços de produção), pois aí a materialidade do dinheiro não é mais a única a determinar os preços absolutos.

existe como uma quantidade distinta dos preços e, portanto, o trabalho abstrato não pode determinar os preços. Trabalho abstrato e preços emergem conjuntamente na esfera da circulação quando o produto é vendido. A crítica de Campbell (2005, p.144)) quanto a isso é dura: esta "value-form theory" comete o erro contrário à "labor-shit theory". Se esta última se livra do dinheiro para manter os valores, a primeira se livra dos valores para manter o dinheiro.

${ }^{92}$ Foley também chega a dizer que "[i]n contemporary economies, then, a fictitious capital, the liability of the state, rather than a produced commodity, functions as the measure of value" (2005, p.46). Porém, de igual maneira, não se sabe o que determina o valor das unidades monetárias nas quais as liablities do Estado são denominadas. O que sugere tomar o capital fictício por equivalente geral (idem, p.48). 
Após a transformação de valores em preços de produção a troca envolve não mercadorias com o mesmo tempo de trabalho socialmente necessário, mas mercadorias com iguais taxas de lucro. Dessa forma, a expressão monetária do trabalho (MELT) somente pode ser determinada após a determinação dos preços das mercadorias (ao contrário do que temos antes da transformação), e só tem validade no plano agregado (e não para cada mercadoria individualmente). Os preços de produção não são determinados através de uma relação unívoca entre valores das mercadorias e o valor do dinheiro-mercadoria (ouro). Ao invés disso, os preços de produção são determinados simultaneamente pela taxa de valorização dos capitais adiantados.

A transformação implica que nenhuma mercadoria pode exercer a função de medida dos valores. Neste nível de abstração, a mensuração do valor envolve a taxa de crescimento dos capitais adiantados através de um sistema complexo de preços relativos. Assim, o dinheiro-mercadoria não mais mensura valores independentes das outras mercadorias e dos processos de produção. A formação dos preços de produção não depende do valor intrínseco do dinheiro-mercadoria (Lapavitsas 2000, p.634). A equalização da taxa de lucro, que é o processo real de formação dos preços de produção, não é afetada pelo fato de os preços serem estabelecidos em unidades de dinheiro conversível ou em unidade de dinheiro inconversível.

No Volume I de O Capital, os preços absolutos são determinados logicamente antes dos preços relativos. Após a transformação, no Volume III, o valor do ouro é relevante só para a determinação do nível absoluto de preços, sendo que aí os preços absolutos são determinados logicamente após os preços relativos. Este é o caso porque neste nível de abstração a medida do valor não é mais dada pelo dinheiro que serve de matéria ao dinheiro, mas sim pela taxa geral de lucro, que é o estabilizador do sistema de preços relativos (Saad-Filho 2002, p.98). Mesmo quando o dinheiro é um mercadoria, como o ouro, a transformação de valores em preços nunca é resultado da simples divisão do valor da mercadoria pelo valor do dinheiro. Para a transformação no nível da concorrência dos capitais, o valor intrínseco de uma matéria do dinheiro não é mais fator crucial e, portanto, a introdução da inconversibilidade do dinheiro não traz nenhum problema adicional (Lapavitsas 2000, p.634). 
Neste nível de análise, portanto, o ouro pode ser retirado, sem prejuízo para a estabilidade da economia ou para a nossa capacidade de entendê-lo. Assim que o ouro é retirado da circulação, os preços absolutos se mantêm ao nível anterior (ou mudam para um nível arbitrário caso haja uma reforma monetária). Um sistema monetário desenvolvido é, portanto, a unidade complexa de uma medida dos valores (a taxa geral de lucro) e um meio-de-circulação (que pode assumir na prática a forma de qualquer material, inclusive impulsos eletrônicos). Mesmo dentro do padrão-ouro esta análise mostra que o ouro nunca é a única medida dos valores nem um adequado meio-de-circulação - ainda que no desenvolvimento teórico o papel do dinheiro-mercadoria seja indispensável (Saad-Filho 2002, p.98-99).

Em suma, diríamos que Saad-Filho e Lapavitsas querem expressar que há uma inversão na lógica da determinação de preços relativos e preços absolutos entre o nível de abstração do capital em geral (Volume I) e o nível de abstração da concorrência dos capitais (Volume III). Inversão esta que faria com que a taxa de lucro também assumisse a função de medida dos valores, para a qual a materialidade do ouro deixaria de ser essencial. Em outros termos: a transformação de valores em preços de produção modifica a função do dinheiro como medida dos valores, mudança que permite a introdução do dinheiro inconversível sem mais problemas.

Esse raciocínio é sem dúvida bem interessante, mas, se bem lido, não responde de fato à pergunta inicial. O que Saad-Filho e Lapavitsas fazem é responder uma pergunta com uma resposta de outra pergunta. Eles deslocam o problema para respondê-lo, afinal de contas a solução proposta parte do nível de abstração dos preços de produção, enquanto o que queremos saber é como o dinheiro inconversível pode funcionar como medida dos valores no âmbito do Volume I (no nível de abstração do "capital em geral"). Um sintoma desse deslocamento que estes autores realizam é que a solução deles é, como a de Foley e Carchedi, válida para qualquer sistema monetário, seja ele de ouro puro, papel-moeda conversível ou dinheiro inconversível pós-1971. Essa inversão em que a taxa de lucro assume papel essencial como medida dos valores é válida universalmente, o que deixa nossa inquietação ainda sem resposta satisfatória ${ }^{93}$.

\footnotetext{
${ }^{93}$ Kristjanson-Gural (2008, p.267-268) também considera insuficiente a solução de Saad-Filho: "It is not true, therefore, that the price of production of gold is irrelevant to the determination of the monetary expression of value, as some have claimed (Saad-Filho 2002, 98-9). Nor is it true, however, that the price
} 


\section{(iii) Arthur}

A abordagem de Arthur (2005, p.115-116) parte da idéias de que na física existem três tipos de medidas:

(a) Medida comparativa direta: a medida compartilha inerentemente a mesma dimensão com o mensurado. Exemplos: balança comum (com contrapeso) e a régua. Neste caso podemos estabelecer arbitrariamente um numerário. A mensuração direta é possível porque ambos os elementos (medida e mensurado) têm uma propriedade a priori em comum, antes da mensuração;

(b) Medida indireta: a medida é externa ao mensurado. Exemplos: balança de mola e termômetros de mercúrio. A distorção da mola ou do mercúrio mostra a força e a vibração das moléculas, e com uma teoria da determinação desta força nós podemos saber o quanto o mensurado mede indiretamente;

(c) Medidas complexas: compostas de outras medidas. Exemplos: $\tau=$ F.d , o que nos exige medir a força e a distância para obtermos o trabalho realizado.

Diz Arthur então que o tempo de trabalho é uma medida imanente, mas que com a passagem do dinheiro conversível ao inconversível a mensuração passou de uma comparativa direta (como faz a balança por contrapeso ou uma régua) para uma indireta (como faz a balança de mola ou o termômetro). Ou seja, agora o dinheiro é uma medida externa e indireta do trabalho. No caso da balança de contrapeso, o contrapeso tem a mesma dimensão do peso a ser mensurado - o que equivale ao dinheiro conversível em ouro. Já no caso da balança com mola, a mola não tem a mesma dimensão do peso a ser medido; a mola mensura o peso embora ela mesma não vigore com o seu peso (ela vigora com sua distorção) - o que equivale ao dinheiro inconversível, que mensura os valores embora ele mesmo não tenha valor.

Esta solução, que opera através de uma analogia com a física, mostra como ocorre a mensuração do valor, mas não o que o determina - e aí voltamos aos dizeres de Foley de que sabemos calcular embora não saibamos o que determina as grandezas de valor.

of production of gold serves as a means to convert values in labor hours into prices of production in currency units". 
Isto é, sabemos como o contrapeso mede o peso, mas não sabemos o que determina a distorção da mola para que esta mensure o peso.

Segue então Arthur pela mesma via da determinação do valor do dinheiro pelo inverso do nível de preços, isto é, pelo seu poder de compra. Porém, diz ele que a medida imediata do trabalho é o tempo, e a do valor é o dinheiro; a medida imediata do valor é o dinheiro, e não o tempo de trabalho (idem, p.118) ${ }^{94}$. O erro estaria, então, supostamente no próprio Marx, que confundiu o "determinante do valor" (tempo de trabalho) com a "medida do valor" (dinheiro). Os valores medidos em trabalho não são determinados ontologicamente antes dos preços monetários. Se o valor é necessariamente mensurado em dinheiro, então os preços de produção são a forma acabada da medida dos valores, e não os preços diretos do Volume I (idem, p.123) com o que Arthur se aproxima da hipótese de Lapavitsas e Saad-Filho.

\section{(iv) Moseley}

Para Moseley o argumento de que a medida dos valores deve ela mesma possuir valor é uma contingência histórica, e não uma necessidade teórica. Para que funcione como medida dos valores, basta que uma coisa particular seja aceita pelos agentes como equivalente universal. Com o fim dos acordos de Bretton Woods os agentes tiveram inevitavelmente que aceitar o papel-moeda inconversível, por si mesmo, como o equivalente universal e, portanto, como medida dos valores. Neste caso o dinheiro inconversível deve funcionar como medida dos valores, embora ele não contenha trabalho incorporado "because there is no other possible measure of value, and no other possible way to represent social labour in na objective form” (2005, p.15). Isto é, o dinheiro não precisa ser uma mercadoria na teoria de Marx, mesmo na determinação de medida dos valores, pois esta não precisa necessariamente possuir valor intrínseco e, portanto, o dinheiro inconversível pode servir nesta função. Para ser medida dos valores uma coisa precisa ser aceita pelos agentes como equivalente geral (Moseley 2004, p.2).

\footnotetext{
${ }^{94}$ Aqui Arthur erra. Como nos lembram Bellofiore (2005) e Campbell (2005), não é o dinheiro que torna as mercadorias comensuráveis, mas o contrário. Se o dinheiro medisse as mercadorias, o valor delas seria só a quantidade de dinheiro pelo qual são trocadas, o preço. Ou seja, se o dinheiro medisse as mercadorias, o preço seria o valor. Se as mercadorias fossem comensuráveis somente por conta do dinheiro, o valor não seria sua propriedade e as relações entre mercadorias não mediariam as relações sociais.
} 
Entretanto, o que determina a quantidade de trabalho social que é representada por uma dada quantidade de dinheiro inconversível? O que determina o "valor do dinheiro" (MELT) quando ele torna-se inconversível? A resposta é desalentadora: "Unfortunately, none of the authors in this book who accept that money as a measure of value does not have to be a commodity has presented an explanation of how the value of money or the MELT is determined in the case of pure non-commodity money" (idem) ${ }^{95}$. Ou, como diz Foley, a determinação do valor do dinheiro é um "abstract theoretical issue [that] remains unresolved" $(2005, \text { p.43 })^{96}$.

\subsubsection{O Problema da Moeda Inconversível como Meio-de-Circulação: Do Símbolo ao Signo}

No item anterior investigamos a moeda enquanto medida dos valores, que é um problema de determinação do valor da moeda. Agora, nossa preocupação é com a moeda enquanto meio-de-circulação, que é um problema de representação do valor.

O cenário do pós-1971 criou uma nova determinação para o dinheiro, peculiar ao capitalismo financeiro e peculiar aos cálculos financeiros que somente os computadores podem realizar. Com o despreendimento da forma em relação à sua matéria, afirmaremos aqui que o dinheiro passou de símbolo a signo e, como signo que não

\footnotetext{
${ }^{95}$ Germer (2005) segue o caminho oposto e fixa sua idéia de que Marx de maneira alguma concebia o dinheiro enquanto medida dos valores como uma não-mercadoria: "[there is a] total absence of any reference in Marx to the hypothesis that money must be at any point become non-commodity" (p.21). Germer erra por não levar em conta os textos dos Grundrisse onde Marx deixa claro que a essência do dinheiro é sua existência como pura forma: "Marx inequivocally defines money as a commodity and ... he maintais this definition in his analysis of advanced capitalism" (idem). Mas Germer também está certo em dizer que Marx não contempla em seus escritos como o dinheiro inconversível operaria como medida dos valores. O problema é que Germer se prende à questão do dinheiro enquanto medida dos valores e daí extrai sua conclusão absoluta (e errônea): "money needs to be a commodity" (idem, p.32). Mas porque razão Marx teria afirmado isso? "The reason is that money derives especially from the mercantile nature of the economy (i.e., from the nature of the sphere of circulation) and not from its capitalist nature (i.e., the nature of the internal constitution of the units of production) which therefore does not affect the nature of money" (idem, p.33). Portanto, se somarmos todas essas citações veremos qual é o problema central de Germer: ele quer entender Marx com a lógica do entendimento e não cede espaço à dialética dos conceitos. Ele trata a exposição marxista como se ela tivesse um caráter axiomático, e não um em que os resultados negam os pressupostos. Dessa forma ele não enxerga que uma determinação do dinheiro pode ser justamente o que nega uma outra determinação do mesmo objeto. Para Germer não existe tal coisa como negação-conservação (Aufhebung). Com sua lógica formal ele só vê negações simples e abstratas.

${ }^{96}$ Para ver a tentativa de solução de Moseley (2004) para este problema, ver a seção seguinte intitulada “O Dinheiro Inconversível Valida a TQM?”.
} 
garante mais sua conversão em ouro, não pode prometer nada além de si mesmo. $\mathrm{O}$ dinheiro, ao passar de símbolo a signo nos traz uma potencial auto-referencialidade (Rotman 1987, p.5) $)^{97}$.

Quando Marx se refere ao "papel-moeda", ele o faz sempre pressupondo a existência do ouro. A determinação "símbolo de valor" que aparece no Capítulo 3 do Volume I de $O$ Capital se refere sempre a um símbolo do ouro; ele é símbolo de algo, de algo material.

Papel-moeda sem lastro (dinheiro inconversível), entretanto, não é símbolo de ouro. Se papel-moeda sem lastro e puramente fiduciário fosse símbolo de valor, seria ele símbolo de qual valor? Se em sua origem histórica e lógica o papel como símbolo designava de fato uma quantia de valor em ouro, com o desenvolvimento do papelmoeda sem lastro a ligação com essa quantia original de valor se perde por completo; apaga sua origem. Que valor então representa a moeda?

Se a forma preço mostra que o ser-real pode ser expresso em um ser-ideal, o símbolo mostra que o ser-dinheiro está separado do seu ser-real (do seu ser-ouro). Sobre o dinheiro como meio-de-circulação temos que o "pressuposto da circulação do dinheiro é a circulação de mercadorias, pois o dinheiro faz circular mercadorias que já têm preço, isto é, que já estão igualadas idealmente a determinadas quantidades de ouro. Mesmo na determinação dos preços das mercadorias, a grandeza de valor da quantia de ouro, que serve de unidade de medida, ou o valor do ouro, é dada como pressuposto" (Marx 1982, p.79). Ou, dito de outra forma: dados os valores de troca das mercadorias e a velocidade média de suas metamorfoses, a "quantidade de ouro circulante depende de seu próprio valor" (Marx 1982, p.81). O que deixa patente que a pressuposição do ouro é essencial nos escritos de Marx para a determinação de meio-de-circulação da moeda.

Se ainda restarem dúvidas de que Marx sempre pressupunha o ouro como dinheiro quando se referia ao símbolo que operava como meio-de-circulação, basta relembrarmos suas próprias palavras: "O sinal de valor, digamos o papel, que funciona como moeda, é sinal da quantia de ouro expressa em seu nome monetário, é portanto sinal do ouro. [...] A grandeza de valor representada por esse sinal depende em cada

\footnotetext{
${ }^{97}$ Para alguns, o dinheiro inconversível pode até alterar o que nós entendemos por espaço e por tempo: "for these new money signs to work requires an accompanying re-coding of time-space" (Pryke e Allen 2000, p.269).
} 
caso do valor da quantia de ouro representada por ele" (Marx 1982, p.86-87). Ou: “As fichas sem valor só são sinais de valor na medida em que representam o ouro dentro do processo de circulação, e o representam só nas quantidade em que o próprio ouro entraria no processo de circulação como moeda, em uma quantidade determinada por seu próprio valor” (Marx 1982, p.88). Ou ainda: “A quantidade de notas de papel deixase, portanto, determinar pela quantidade de dinheiro-ouro que elas representam na circulação: e uma vez que só são sinais de valor na medida em que representam o ouro, o valor delas é determinado simplesmente por sua própria quantidade. Enquanto a quantidade de ouro circulante depende dos preços-mercadoria, o valor das notas de papel em circulação depende, ao contrário, exclusivamente da sua própria quantidade" (Marx 1982, p.89). O preço se torna existência ideal e o dinheiro se torna existência simbólica dos valores-de-troca. As passagens acima citadas são enfáticas neste ponto. Aqui temos com todas as suas letras a prova do que queremos mostrar. Marx é bem claro: símbolo é representação; o símbolo de valor é símbolo de ouro, e o valor representado por ele deriva do valor do ouro pressuposto. Além do mais, Marx também afirma que a oferta de símbolos de valor é regulada pelas leis que determinam as quantias de ouro representadas por esses símbolos. É uma questão de substituição. O que o ouro faria e como ele é exigido pela circulação fica então substituído por seu símbolo. O símbolo faz o que o seu representado faria ${ }^{98}$.

Qual é o papel do Estado nesta circulação simples? Em princípio, a ação do Estado, diz Marx (1982, p.89) parece abolir as leis econômicas da circulação da moeda. Como a moeda obtém curso forçado através dos Governos, parece que este pode imprimir quanto papel-moeda lhe aprouver e com o valor de face que bem desejar. Contudo, esse poder Estatal é "pura aparência", pois uma vez que a oferta monetária seja absorvida pela circulação, o "sinal de valor ou a moeda-papel cai sob o domínio das suas leis imanentes" (idem). Se for lançada em circulação uma quantia de notas cuja soma dos valores de face ultrapasse a quantia de ouro que de fato deveria circular, só se alteram as denominações convencionais do padrão de preços. Aumentando a oferta de símbolos, só faria com que diminuísse a quantia de ouro que cada símbolo individual representa. $\mathrm{O}$ aumento de preços, ou a inflação, seria uma resposta da circulação em exigir que os

\footnotetext{
98 "Se houver papel-moeda demais ou de menos relativamente ao ouro que ele substitui, o valor desses papéis de alterará" (Fausto 1997, p.116 - ênfase nossa). Vale ressaltar também que para Fausto (idem), o que determina o valor do papel-moeda é sua quantidade.
} 
símbolos de valor se igualem à quantia de ouro que representam. O que também deixa mais claro como Marx pensa a inflação também em relação ao ouro; ou seja, o processo inflacionário seria um ajuste do mercado ao perceber que circula mais papelmoeda do que o ouro que deveria representar ${ }^{99}$.

O que seria, então, a inflação com dinheiro inconversível? O que define a oferta monetária que não provoca inflação? Como veremos no próximo capítulo, esta problemática e a questão da determinação do que seja uma taxa cambial de equilíbrio quando reina a forma inconversível do dinheiro permanecem ainda sem resposta satisfatória dentro da tradição marxista.

Na circulação simples, a circulação do ouro e a circulação do papel-moeda (lastreado) parecem seguir leis invertidas:

\begin{tabular}{|l|l|}
\hline \multicolumn{1}{|c|}{ Circulação do Ouro } & Circulação do Papel-Moeda (lastreado) \\
\hline Circula por que tem valor & Tem valor porque circula \\
\hline $\begin{array}{l}\text { Dado os valores-de-troca das mercadorias, } \\
\text { a quantidade de ouro circulante depende } \\
\text { de seu próprio valor }\end{array}$ & $\begin{array}{l}\text { Seu valor depende de sua oferta, e não do } \\
\text { seu valor }\end{array}$ \\
\hline $\begin{array}{l}\text { A quantidade de ouro circulante é função } \\
\text { dos preços das mercadorias }\end{array}$ & $\begin{array}{l}\text { O preço das mercadorias é função da } \\
\text { quantidade de papel-moeda circulante }\end{array}$ \\
\hline $\begin{array}{l}\text { A quantia de ouro circulante é dada pela } \\
\text { circulação de mercadorias, isto é, pelo } \\
\text { mercado }\end{array}$ & $\begin{array}{l}\text { A oferta de papel-moeda parece ilimitada } \\
\text { e resultado da decisão do Estado, e não do } \\
\text { mercado }\end{array}$ \\
\hline $\begin{array}{l}\text { Há uma lei econômica para a oferta de de } \\
\text { ouro }\end{array}$ & $\begin{array}{l}\text { Não há lei econômica para a oferta de } \\
\text { símbolos }\end{array}$ \\
\hline $\begin{array}{l}\text { Ouro expressa o valor das mercadorias } \\
\text { mediatizado pelo preço }\end{array}$ & $\begin{array}{l}\text { O símbolo parece representar } \\
\text { imediatamente o valor das mercadorias }\end{array}$ \\
\hline
\end{tabular}

Portanto, no que concerne à definição de inflação de Marx deve ficar claro que a proporção em que os símbolos representam pesos de ouro (calculados de acordo com seu preço monetário convencional) não depende de sua própria matéria, mas sim de sua oferta. A dificuldade teórica advém da dupla determinação da moeda tanto como medida dos valores como meio-de-circulação, determinações contrárias e aparentemente contraditórias:

\footnotetext{
99 Sobre a inflação, Marx é explícito: "O aumento dos preços seria apenas uma reação do processo de circulação, que obriga os sinais de valor a igualarem-se à quantia de ouro, cujo lugar na circulação pretendem ocupar" (Marx 1982, p.89). Ou também: "A alta ou baixa de preços das mercadorias, em virtude do aumento ou da diminuição da massa de notas de papel [...] nada mais é do que a ação violenta do processo de circulação, fazendo valer a lei burlada mecanicamente de fora” (Marx 1982, p.90).
} 


\begin{tabular}{|l|l|}
\hline \multicolumn{1}{|c|}{ Medida dos Valores } & \multicolumn{1}{c|}{ Meio-de-Circulação } \\
\hline Dinheiro ideal & Dinheiro simbólico \\
\hline $\begin{array}{l}\text { Papel-moeda é moeda de cálculo, e o ouro } \\
\text { é ouro ideal }\end{array}$ & $\begin{array}{l}\text { Apesar de representada, a moeda ainda } \\
\text { tem que estar efetivamente nas mãos dos } \\
\text { indivíduos }\end{array}$ \\
\hline Tudo depende do ouro como matéria & O material da moeda é indiferente \\
\hline $\begin{array}{l}\text { O dinheiro é idealizado (sua existência } \\
\text { efetiva não exigida) mas tudo depende de } \\
\text { sua substância material }\end{array}$ & $\begin{array}{l}\text { O dinheiro é tangível mas tudo depende } \\
\text { de uma proporção numérica ideal }\end{array}$ \\
\hline Momento positivo, finito & Momento negativo, mau infinito \\
\hline Universalidade abstrata, idealidade & \begin{tabular}{l} 
Particularidade, realidade \\
\hline $\begin{array}{l}\text { O convencional e o natural aparecem no } \\
\text { lado ideal e do sujeito }\end{array}$
\end{tabular} $\begin{array}{l}\text { O convencional e o natural são efetivados, } \\
\text { aparecendo no lado do objeto e do real }\end{array}$ \\
\hline $\begin{array}{l}\text { O ouro não precisa estar presente; pode } \\
\text { ser representado }\end{array}$ & $\begin{array}{l}\text { A presença do ouro não pode ser } \\
\text { representada; ela tem de ser efetiva }\end{array}$ \\
\hline $\begin{array}{l}\text { A presença é representada, mas o objeto } \\
\text { representado não pode ser simbólico }\end{array}$ & $\begin{array}{l}\text { A presença efetiva pode ser simbólica } \\
\text { (não-imediata) }\end{array}$ \\
\hline $\begin{array}{l}\text { Dinheiro é ideal, mas não pode ser } \\
\text { simbolizado }\end{array}$ & $\begin{array}{l}\text { Dinheiro é real, embora possa ser } \\
\text { simbolizado }\end{array}$ \\
\hline
\end{tabular}

A tabela deixa claro que o dinheiro enquanto meio-de-circulação inverte as relações do dinheiro enquanto medida dos valores. Os símbolos de valor invertem e transgridem sua proporção correta para com o ouro, dado pela função de medida dos valores. Ou seja, existe uma proporção correta (não inflacionária) que é dada pelo dinheiro como medida dos valores; porém, esta proporção é negada pelo dinheiro como meio-de-circulação e, especialmente, pelos símbolos de valor. Sinteticamente colocado, a inflação para Marx, que se restringia à inflação com dinheiro conversível, é o modo pelo qual a alterada medida dos valores torna-se novamente compatível com a função de meio-de-circulação. Ou seja, é o modo através do qual a circulação de mercadorias re-impõe sua proeminência sobre a aparente habilidade estatal de querer determinar arbitrariamente a quantidade de papel-moeda lastreado em ouro (Lapavitsas 1994, p.450). Com o dinheiro inconversível essa lei da proporção correta do dinheiro como medida dos valores ainda é mantida ou completamente negada? ${ }^{102}$

\footnotetext{
100 A convencionalização do dinheiro enquanto meio-de-circulação "não é produção de um novo significante para um mesmo significado, mas, pelo contrário, a criação de um novo significado para um mesmo significante" (Fausto 1997, p.114).

${ }^{101}$ As cinco primeiras linhas desta tabela foram escritas a partir do Zur Kritik (Marx 1982), enquanto que as demais foram escritas a partir de Fausto (1997, p.110-117).

${ }^{102}$ Para algumas modernas teses marxistas sobre a inflação com dinheiro inconversível recomendamos Carchedi (1991, p.166,170,172-174,176) e Saad-Filho (2002; p.100-105 e p.145 n.32-33).
} 
Sabemos claramente que Marx de fato apontou a tendência lógica e social da moeda em se descolar gradualmente de seu conteúdo material, inclusive chegando a afirmar que o limite desta tendência seria o dinheiro como pura forma ${ }^{103}$. Entretanto, como tentamos mostrar, Marx, ao falar do dinheiro enquanto símbolo, afirma inúmeras vezes que este símbolo é uma representação, onde figura o ouro como representado. A categoria de “símbolo" condiz ao papel-moeda fiduciário lastreado. A forma contemporânea do dinheiro completamente inconversível parece, então, não se enquadrar nas categorias apresentadas por Marx. Seu raciocínio pressupõe a mercadoria ouro como substância, o que hoje não é mais verdadeiro. Chegamos, portanto, a outro impasse conceitual ao tentarmos dizer logicamente o que é o dinheiro inconversível, sem lastro, enquanto meio-de-circulação.

Seria o papel-moeda inconversível símbolo de trabalho abstrato? Como vimos, essa hipótese está descartada, pois voltaríamos à teoria da Escola de Birmingham e às teorias que igualmente tratam o dinheiro diretamente como mercadoria, sem mediações e não perpassados pela negatividade, como no caso dos já conhecidos "bônus trabalho" ou "tickets de trabalho" ou "vale-trabalho", duramente criticados por Marx (1982, p.6667,87). O símbolo não é símbolo direto do valor-de-troca, mas símbolo do ouro, do valor-de-troca autonomizado, mediatizado. Desse modo, ainda que Marx reconheça que "papel-moeda nacional de curso forçado é a forma acabada do sinal de valor" (Marx 1982, p.87), ele ainda se encontra preso ao padrão-ouro. O curso forçado nesse caso evidencia que a moeda precisa ter aceitação geral, social, e, portanto, legal. O modo de ser do símbolo precisa ser aceito universalmente. O curso forçado torna-se, assim, convenção; mas uma convenção derivada da circulação das mercadorias, e não da ação do Estado.

Vemos que a materialidade do ouro é importante não somente para a determinação da moeda como medida dos valores - como deixamos explícito no item precedente , como também a materialidade do ouro é importante, pois pressuposta, para a determinação da moeda como meio-de-circulação. O símbolo é símbolo de ouro e sua quantidade é regulada por ele. Como medida dos valores o ouro está posto, e

103 "The material in which this symbol is expressed is by no means a matter of indifference [...]. In the development of society, not only the symbol but likewise the material corresponding to the symbol are worked out - a material from which society later tries to disentangle itself” (Marx 1973, p.145). 
como meio-de-circulação o ouro está posto como pressuposto, posto como negado. $O$ símbolo ainda tem uma "sombra" de ouro, se por "sombra" entendermos a pressuposição como posição, e não como mera pressuposição externa ${ }^{104}$. Dessa forma, a restrição de Marx ao cenário monetário imposto no século XIX nos traz dois problemas teóricos quando confrontada com o pós-1971.

Necessitamos, contudo, agora diferenciar mais a fundo o que é símbolo [Sinnbild/ Symbol] e o que é signo [Zeichen] (Müller 2007, Safatle 2006, p.111-112 e Derrida $1991)^{105}$.

O símbolo é uma existência exterior imediata que não deve ser tomada do mesmo modo com se apresenta; isto é, se é dada de forma imediata, seu significado não é imediato, mas sim remete a um sentido mais amplo e universal. Neste caso o conteúdo da relação tem um grau pequeno de arbitrariedade, pois em sua existência mesma já há algo do significado. "Contra o arbitrário do signo ..., Hegel contrapõe inicialmente o caráter motivado do símbolo, no qual o conteúdo da intuição é 'mais ou menos' apresentado no que o símbolo exprime" (Safatle 2006, p.112). Um exemplo é tomar o leão como símbolo da coragem. Existe uma arbitrariedade, pois poderíamos escolher outros animais "corajosos", mas o leão de fato tem uma ligação não-arbitrária com a coragem (donde vem sua "fama" de "rei da floresta"), ou poderíamos escolher outras características do mesmo leão, como sua juba ou o seu rugido. Portanto, há uma infinidade de possibilidades de conexão entre expressão e significado, sendo que a expressão em particular que vigora depende de uma convenção partilhada socialmente que impede que tenhamos outras interpretações também perfeitamente possíveis. Isto é, "a motivação do símbolo é contextual" (idem); o símbolo é dependente de uma referência social, de uma convenção social, tal que não desemboque em outras significações.

Com o signo a relação torna-se inteiramente arbitrária, pois é designação em que a conexão entre significado e significante é muito frouxa: "Para Hegel, o signo está ligado à lógica da representação e da adequação própria ao que a doutrina da essência chama

${ }^{104} \mathrm{O}$ leitor, em caso de dúvida quando ao sentido do tema, pode rever as explicações subjacentes à figura 1.2 no capítulo 1 deste trabalho.

${ }^{105}$ Agradeço a Leda Paulani por ter me avisado desta importante distinção entre símbolo e signo para compreendermos a forma dinheiro atual. 
de reflexão exterior [...]. A relação arbitrária que o signo sustenta é assim evidente, pois ele representa um conteúdo distinto do que aparece à intuição. Estranha 'intuição imediata' esta posta pelo signo, já que é uma intuição que conserva a distância entre o conteúdo intuído e o conteúdo representado, entre o que é visado (Meinung) e o que é efetivamente dito" (Safatle 2006, p.111-112). É a "intuição da ausência" (Derrida 1991, p.120). Os signos estão circunscritos a um campo autônomo frente aos objetos que designam, um campo com regra e lógica próprias, e daí a conexão arbitrária. $\mathrm{O}$ conteúdo está apartado do que é intuído, isto é, há uma distância significativa entre o que é intuído pelo indivíduo e o que é efetivamente expresso, entre significado e significante - o que configura um modo de expressão justamente adequado ao pensar representativo ${ }^{106}$ através de uma perspectiva externalista.

Em suma, nossa idéia é a de que Marx pensou o dinheiro enquanto meio-decirculação como símbolo, e não como signo, onde figura a definição de inflação no Zur Kritik como prova definitiva. Quem pôs definitivamente o dinheiro como signo foi o dinheiro inconversível ${ }^{107}$. Ou seja, se o dinheiro conversível - ainda que fosse papelmoeda - enquadra-se no que Hegel denominou por símbolo, uma relação entre significado e significante que guarda um momento de não-arbitrariedade, o dinheiro inconversível do pós-1971 realizou a passagem do dinheiro enquanto símbolo ao dinheiro enquanto signo, para o qual a relação de significação é totalmente arbitrária.

\subsection{Dinheiro Enquanto Dinheiro}

\subsubsection{O Dinheiro como Negação Determinada}

A seção anterior lidou com o dinheiro enquanto moeda. A seção presente, ao contrário, tratará do dinheiro enquanto dinheiro de fato, para o qual a forma se torna conteúdo (Fausto 1997, p.120). As mercadorias, agora, são mediadoras do próprio processo do

\footnotetext{
${ }^{106}$ Sobre a crítica de Hegel ao pensar representativo, que aparta o objeto do sujeito, ver nosso capítulo primeiro.

${ }^{107}$ Sobre a passagem do dinheiro enquanto símbolo para dinheiro enquanto signo, Müller (2007) conclui que aí "o capital abandonou plenamente os últimos resquícios de sua aderência ao plano natural: ao ser o ouro - um símbolo - substituído por mero signo, o capital autonomiza-se de maneira total e completa" (p.137). Esta é a “modernidade do capital”, triunfo do pensar representativo através dos signos.
} 
dinheiro em vir-a-ser dinheiro. Essa passagem da moeda ao dinheiro é a negação e conservação do dinheiro como meio, para ser dinheiro como fim; e, por isso mesmo, torna-se também capital pressuposto. O movimento do dinheiro, contudo, é um mau infinito $^{108}$. O bom infinito é o capital (idem, p.119). O dinheiro é a riqueza universal em seu aspecto individual. O dinheiro é, acima de tudo, um universal-concreto. É o universal que convive ao lado dos particulares; é "o" particular, e não "um" particular; é como se existisse concretamente "o animal" ao lado dos animais particulares (leões, vacas etc.). O dinheiro é indivíduo-gênero.

Se a moeda era a relação das mercadorias consigo mesmas mediatizadas pelo dinheiro, o dinheiro enquanto tal é relação consigo mesmo mediatizado pelas mercadorias. O dinheiro, assim sendo, é a negação determinada da moeda. E, mais do que isso. É justamente na passagem da forma moeda à forma dinheiro que se opera a inversão sujeito-objeto. O que era objeto na troca (a moeda) torna-se sujeito (dinheiro). Se as mercadorias usavam a moeda para se trocarem entre si, agora tornam-se elas objeto do dinheiro. O sujeito deixou de ser a mercadoria para ser o dinheiro.

O dinheiro enquanto tal não é a unidade da medida dos valores com o meio-decirculação, mas sim um terceiro momento que realiza e conserva ao negar seus dois momentos anteriores. A moeda é o pressuposto do dinheiro, e esse não é a unidade daquela. Como dinheiro de fato, o dinheiro tem uma existência fora da circulação. Se a moeda afirmava a circulação, o dinheiro a nega e a conserva no seu próprio devir. Assim, para ser acumulado como dinheiro, tem ele de ser totalmente desenvolvido como medida dos valores e como meio-de-circulação; pois, caso contrário, seria mera acumulação de metais ou de papéis, e não de dinheiro de fato. Dito de outro modo, o dinheiro nega a moeda por três razões: (a) como tesouro retira-se da circulação, deixa de ser meio para ser fim e exerce sua função de reserva de valor; (b) como meio-depagamento nega o meio-de-circulação, e com isso novamente deixa de ser meio para ser fim. Se a teoria não apreendeu tal distinção entre meio-de-compra e meio-depagamento, a prática das crises com certeza o faz; (c) como dinheiro universal rompe as barreiras nacionais e torna-se equivalente universal, dinheiro universal.

\footnotetext{
108 “[...] ainda que o dinheiro ... não chegue a atingir o conceito, mostra-se fenomenicamente com toda a dimensão que esta figura tem na dialética hegeliana” (Paulani 1991, p.134).
} 
Como dinheiro enquanto dinheiro, a relação de troca se estabelece como um poder externo e independente dos produtores. O que originalmente aparecia como meio para promover a produção, torna-se uma relação estranha a seus agentes. Enquanto os produtores tornam-se cada vez mais dependentes das trocas, mais elas aparecem como independentes de sua vontade (Marx 1973, p.146). O dinheiro não cria tais contradições, mas ao contrário, é o desenvolvimento dessas contradições que cria este aparente poder transcendental do dinheiro. É uma propriedade do processo formativo do dinheiro realizar seus propósitos ao simultaneamente negá-los (idem, p.151):

(a) Supera as dificuldades das trocas ao justamente generalizar tais dificuldades; torna a contradição particular uma contradição geral, social;

(b) Como mercadoria, torna-se independente delas;

(c) É um meio que se torna um fim;

(d) Realiza os valores-de-troca das mercadorias ao separá-las deles;

(e) Facilita as trocas dividindo-as em atos contraditórios (venda e compra);

(f) Torna as trocas independentes dos produtores ao mesmo tempo em que os produtores se tornam cada vez mais dependentes delas.

O dinheiro não faz oposição externa à mercadoria, mas dela surgiu, dela é constituinte, e dela é o seu contrário, seu oposto interior. Assim, o surgimento lógico da forma dinheiro se constitui em um exemplo excelente da diferença entre uma mera negação opositiva, entre termos externos uns aos outros (como em uma relação de tese e antitese), e uma negação determinada, negação produtora, negação que produz um novo ser. O dinheiro não é introduzido como um objeto externo que se opõe à mercadoria. Ele emerge dela, do seu interior e de sua realização. Ao realizar o seu conceito, a mercadoria afirma o contrário de si mesma; sua negação é sua afirmação. A verdade da mercadoria é o dinheiro, e a verdade do dinheiro é o capital. 


\subsubsection{O Crédito como Capital Fictício Embrionário: 0 "Dinheiro Fictício"}

O crédito é, acima de tudo, um adiantamento de poder de gasto que não encontra equivalente imediato. Seu equivalente ainda é um vir-a-ser, uma produção futura. Neste sentido, parece que há algo de fictício, ou melhor, de um "dinheiro fictício" já na posição do dinheiro como meio-de-pagamento, como crédito. Do mesmo modo como a expansão do capital, tendo em vista uma valorização esperada pode não se concretizar, a expansão dos meios-de-pagamentos, tendo em vista um retorno em mercadorias reais, também pode não se concretizar. Ou seja, no dinheiro enquanto meio-de-pagamento já há potencialmente um "dinheiro fictício", um crédito que ainda não encontra um equivalente real de mercadorias:

"O crédito torna o refluxo em forma-dinheiro independente do momento do refluxo real [...]. A aparência de refluxos rápidos e seguros continua mantendo-se por algum tempo, depois que essas condições deixaram de ser reais [...]. Os bancos começam a farejar o perigo tão logo seus clientes pagam mais com letras do que com dinheiro" (Marx 1984a, p.341).

Hilferding (1981, p.70) faz uma análise interessante do crescente uso do dinheiro enquanto meio-de-pagamento. Afirma ele que, excetuando a figura do capital-portadorde-juros e centrando a análise na circulação, vê-se que o capitalista, ao fazer seus investimentos iniciais, compra trabalho e máquinas. O trabalho ele só pode pagar com meio-de-circulação, mas o capital fixo ele pode comprar com crédito. Sua conclusão é a de que com o aumento da composição orgânica do capital (aumento relativo do capital fixo em relação ao variável) tem-se logicamente um acréscimo relativo a importância dos meios-de-pagamento sobre os meio-de-circulação. $\mathrm{O}$ que corrobora os dizeres de Marx de que "na medida em que o crédito ... se desenvolve, o papel do dinheiro como meio-de-pagamento vai adquirir importância em detrimento do papel que desempenha como meio-de-circulação (1982, p.239). Porém, na crises dá-se o inverso, pois aí desaparecem os meios-de-pagamento é todos só aceitam meio-de-circulação. 
O crédito, ao acelerar a produção e ao separar paulatinamente compra e venda, funciona de base à especulação e à superprodução. O crédito tem, desse modo, duplo aspecto: intensifica a produção e intensifica ao mesmo tempo suas contradições.

No capítulo anterior vimos que Henry Thornton critica a Lei do Refluxo e a Real Bills Doctrine através da demonstração de que parte do crédito já é inerentemente fictício, já que se constitui em uma "aposta" sobre a produção ainda não realizada. Este é o nosso ponto aqui: o meio-de-pagamento como determinação do dinheiro é a forma lógica mais embrionária de capital fictício. Isto porque o meio-de-pagamento "always has a fictitious, imaginary component" (Harvey 2007, p.267). Este "dinheiro fictício" é um direito sobre a futura produção de mais-valia. Dessa forma, todo capital adiantado é capital fictício: "From the very outset ... the money capital advanced has to be regarded as fictitious capital because it is not backed by any firm collateral" (idem). Marx, em seu século já expressava isto:

"Na medida em que o Banco emite notas, que não são cobertas pela reserva metálica guardada em seus cofres, ele cria signos de valor que constituem para ele não apenas meios de circulação, mas também capital adicional, ainda que fictício, no valor nominal dessas notas sem cobertura. E esse capital adicional proporciona-lhe lucro adicional" (Marx 1984b, p.69).

Tomando por base os escritos de Hilferding, ainda que sem mencioná-lo, Harvey deriva que da crescente importância relativa dos meios-de-pagamento sobre os meios-decirculação segue-se uma maior criação de valores fictícios a fim de financiar investimentos de longo prazo: "Fictitious capital is as necessary to accumulation as fixed capital itself” (2007, p.269). Isto é, há uma crescente dependência da formação de capital fixo em relação à criação de capital fictício. Assim sendo, a forma mais essencial ao capital e a dita mais "sólida", que é o capital fixo, fundamento de todo o progresso tecnológico moderno, assenta-se principalmente sobre a formação do que há de mais fictício. Para que o mais "fixo" e "sólido" se estabeleça, o mais "fictício" e 
“ilusório" deve ser posto ao seu favor ${ }^{109}$. O que nos faz lembrar da frase de Marx de que no capitalismo "tudo que é sólido se desmancha no ar".

\subsubsection{O Dólar Inconversível Pós-1973 como Dinheiro Mundial}

Para tornar-se objeto adequado ao seu conceito, precisa o dinheiro, segundo Marx, torna-se universal, dinheiro mundial que não conhece fronteiras nem limitações regionais: "Só no mercado mundial ... sua maneira de existir torna-se adequada a seu conceito.” (Marx 2002, p.169), ainda que não seja uma determinação adicional, senão um de seus usos (Marx 1982, p.109). Transparece agora a divisão entre as esferas nacionais e internacionais da circulação. O dinheiro como símbolo de valor, como pura existência funcional, mostra-se restrito à esfera interna de um país, sujeito à ação coercitiva legal. Enquanto dinheiro do comércio mundial retorna o dinheiro à sua forma corpórea de metal: "Para circular fora da esfera nacional, despe-se o dinheiro das formas locais nela desenvolvidas de estalão dos preços, moeda, moeda divisionária e símbolo de valor, e volta à sua forma original de barra de metais preciosos.”. O que nitidamente evidencia como Marx encontrava-se preso ao padrão-ouro do século XIX ${ }^{110}$.

O dinheiro mundial é o meio universal de pagamento, encarnação absoluta da riqueza. Não é fortuitamente que Marx emprega as expressões "universal" e "absoluto" neste caso. Trata-se, pois, da riqueza incondicionada, infinita. Mas o dinheiro só pôde ser dinheiro universal com a universalização do comércio, das trocas de mercadorias. É a mercadoria universal. Se o dinheiro enquanto meio-de-circulação negava o dinheiro enquanto medida dos valores, o dinheiro enquanto dinheiro mundial é negação da negação, pois é meio-de-circulação que volta também à determinação de medidas dos valores. Isto é, depois de passar da posição da matéria para a posição da forma, o dinheiro volta como posição da forma e da matéria, ainda que negue ambas para conservá-las.

\footnotetext{
${ }^{109}$ Foley, erroneamente, discorda disto: "Loans to productive capitalists are 'real capital'; they are part of the money capital committed to the circuit of capital to finance production" (2005, p.45).

${ }^{110}$ Vemos que Marx não concebia que o poder estatal pudesse transcender os limites de uma nação: "A coerção do Estado vigora apenas na esfera interna da circulação, contida dentro das fronteiras de uma comunidade, e só nela desempenha o dinheiro plenamente sua função de meio de circulação e assim pode ter no papel-moeda pura existência funcional, exteriormente distinta de sua substância metálica" (Marx 2002, p.156). O “interior [de um país] já agora não precisa de dinheiro metálico" (Marx 1984b, p.49).
} 
Se em Marx a universalização do dinheiro como dinheiro mundial o faz retornar ao dinheiro metálico, entendemos que Marx não tinha em mente o dinheiro inconversível como dinheiro universal e nem como realização de seu próprio conceito. Se Marx acertou em afirmar que o dinheiro universal é a efetivação do conceito de dinheiro, errou objetivamente ao não ver que sua própria tendência de se descolar de seu conteúdo também seria uma realização de seu conceito. Ou seja, o dinheiro como pura forma estaria restrito ao âmbito doméstico.

Os Grundrisse evidenciam que dinheiro entra em contradição consigo mesmo por ser justamente a encarnação da contradição entre algo que é particular, pelo fato de ser uma determinada mercadoria (ainda que seja símbolo), sujeita a condicionantes particulares, e o fato de ser algo incondicionalmente permutável (Marx 1973, p.150). Quando o ouro opera de fato como equivalente geral ou quando símbolos os substituem, ainda permanece uma contradição não resolvida entre o dinheiro enquanto funcionalidade (como valor-de-troca autônomo) e o dinheiro como mercadoria particular, cuja grandeza de valor decorre de seus próprios custos de produção. Isto é, a contradição do dinheiro papel-moeda lastreado está entre sua universalidade como equivalente geral e sua particularidade como mercadoria ouro sujeita às oscilações naturais de qualquer produção.

Assim sendo, podemos aqui defender a tese de que a forma dinheiro sem lastro, dinheiro inconversível, resolve tal contradição justamente por desprender-se de qualquer materialidade particular. Não há mais o ouro como mercadoria para impingir seus custos de produção sobre o papel-moeda. No dinheiro inconversível parece não haver mais essa contradição entre particular e universal, entre condicional e incondicional, afinal não está mais o dólar preso a qualquer mercadoria em específico. O dólar hoje é, assim, um puro universal, um puro incondicionado. Mas esta é só a aparência. Em sua figura dissolve-se a contradição entre particularidade e universalidade como está presente nos escritos de Marx para dar lugar a uma nova contradição em um patamar mais elevado ${ }^{111}$ : entre particularidade, como moeda de um país em específico, e universalidade, como moeda mundial. O dólar é, assim, um singular,

111 Afinal "cada determinação se desdobra no interior dela mesma para produzir uma nova oposição" (Fausto 1997, p.46). 
universal-concreto $^{112}$. Esta é sua nova essência. Em outras palavras, a contradição que a moeda do padrão-ouro apresentava, ainda que símbolo, entre o fato de ser ouro e de ser uma relação social, repõe-se hodiernamente como o fato de ser moeda nacional e internacional ao mesmo tempo. O padrão dólar puro resolve a contradição do dinheiro ao generalizá-la, ao torná-la, de fato, mundial.

Aí, portanto, está ao mesmo tempo um dos limites e uma das riquezas da teoria monetária original de Marx: o dinheiro é essencialmente pura forma. Faltou-lhe vivenciar o que hoje temos: a perfeita adequação da forma dinheiro à sua matéria, uma não-matéria. $\mathrm{O}$ dinheiro do padrão dólar puro resolve a contradição entre forma e matéria, entre função universal e condicionamento particular, ao expulsar completamente a matéria e ao colocar a contradição em termos de dinheiro particular de um país e dinheiro global, universal. Como pura forma o dinheiro é verdadeiro, isto é em linguagem hegeliana - está de acordo com seu conceito. Em suma, poderíamos dizer que a aparência do dinheiro no pós-1971 é a de que sua contradição entre forma e matéria (entre incondicionalidade e condicionalidade, entre universalidade e particularidade) foi resolvida. E de fato foi mesmo, pois não mais há tal inadequação que havia no caso do padrão-ouro clássico ou do padrão dólar-ouro de Bretton Woods. Esta aparência, no entanto, já revela algo da ordem da essência: a de que o dinheiro é em essência forma pura ${ }^{113}$.

De certa maneira, o próprio Friedman (1968) sabia que o padrão dólar-ouro de Bretton Woods era um falso padrão e que seu intrínseco mecanismo de ajuste era perverso. Dizia ele que o verdadeiro padrão-ouro e o verdadeiro regime internacional de câmbio fixo fora aquele que vigorara entre 1880 e 1913, no qual as autoridades monetárias eram

112 “Há um 'compromisso hierárquico', segundo a expressão de J. Leonard, que reflete a contradição entre a necessidade de haver uma referência monetária comum para as transações internacionais e a manutenção da especificidade das moedas nacionais" (Brunhoff 2005, p.76). Ou também: "o acordo de Bretton Woods consagrou o dólar como moeda internacional e criou o FMI para a sustentação de um regime de câmbio fixo 'ajustável', mas a inconsistência entre os papéis do dólar como moeda nacional e internacional acabaria por levar ao colapso do sistema e à reinvenção do FMI" (Carvalho 2004, p.5). "[...] there is a fundamental conflict in contemporary capitalism, in which one nations' money functions as world money (as the US dollar currently does)" (Moseley 2005, p.17). "[T]he absence of a world nominal anchor to take the place of gold, the pound or the dollar, generates a conflict inherent in the dual role of the dollar as America's currency and the world currency" (Frankel apud Brunhoff, p.219)

113 Ainda assim o dinheiro deve manter sua aparência de mercadoria, seja ele ouro ou não: no século XX, "a aparência de mercadoria do dinheiro pode perfeitamente ser fornecida, inclusive a nível mundial, por um simples papel verde sem qualquer vínculo, por remoto que seja, com o ouro ou com qualquer mercadoria particular. [...] a essência da aparência de mercadoria do dinheiro é, ela própria, puramente formal" (Paulani 1991, p.146 - ênfases nossas). 
passivas. Naquele caso, a verdadeira moeda, o ouro, fazia com que o mecanismo de ajuste global fosse automático e virtuoso. O que não ocorria com o regime de 1944 a 1970, pois o ouro aí figurava como uma referência oficial através do dólar, e não como moeda de fato privada. Trata-se, desse modo, de um "falso padrão-ouro" cujo aspecto artificial se expressa em um mecanismo de ajuste internacionalmente desestabilizador, transformando o déficit em balanço de pagamentos e o endividamento fiscal dos EUA em um problema global. A solução era, dizia Friedman antes mesmo de Nixon romper com o câmbio fixo, introduzir regimes cambiais flexíveis e acabar com a "falsa conversibilidade" do dólar em ouro, para o qual os mecanismos de mercado tratariam de resolver os problemas de déficit em balanços de pagamentos. Isto é, afirmamos aqui que Friedman (1968), neste sentido, concordava com a idéia de que o dinheiro inconversível como dinheiro mundial é uma forma mais adequada ao conceito de dinheiro, pois elimina as incongruências de um "falso padrão-ouro" de Bretton Woods.

A hegemonia do dólar na hierarquia monetária internacional foi uma "solução" contraditória para o problema contraditório entre a moeda norte-americana e as moedas nacionais dos grandes países. Ou seja, a hierarquia de moedas, ou o original sin segundo Eichengreen e Hausmann (2005), é a solução contraditória para um problema prático contraditório. Além do mais, o dólar está atrelado ao duplo déficit dos EUA, que são financiados por conta de sua posição como principal espaço de crédito mundial (Brunhoff 2005, p.80-81). Portanto, no caso desta hegemonia fica evidente como a posição do dinheiro enquanto moeda (medida dos valores e meiode-circulação) depende de sua posição como dinheiro de fato (meio-de-pagamento e reserva de valor). Em outras palavras, o dólar como moeda mundial é garantido por sua função de crédito mundial. Crédito este totalmente conjugado à formação de capital fictício através da dívida estatal.

Pelo que acima discutimos pode-se ver que a posição do dólar como moeda global sem lastro tem uma dupla constituição contraditória: é moeda particular e universal ao mesmo tempo - pois é moeda dos EUA e do mundo ao mesmo tempo -, e aparece como existência efetiva quando em essência é existência necessária. Isto é, aparece como efetividade cuja necessidade não é absoluta, necessidade contingente, externa, fruto de um capricho institucional norte-americano; mas que em sua 
essência nega tal aparência para se pôr como existência necessária, não apenas existente, mas existente necessariamente. Dessa forma, o dinheiro inconversível aparece como contingente para se afirmar de fato como necessário. É quando consolida sua aparência de simples capricho, simples convenção, que se afinca mais profundamente como a necessidade forte que é. Quanto mais necessário se torna, mais como contingência se apresenta.

\subsection{O Dinheiro Inconversível Valida a Teoria Quantitativa da Moeda?}

Para a TQM, a determinação do valor-de-troca do dinheiro inconversível não representa nenhum problema especial: todas as formas de dinheiro inconversível são tratadas como convenções que substituem o dinheiro-mercadoria. $\mathrm{O}$ argumento central é o de que a oferta monetária é determinada arbitrariamente (exogenamente) por uma autoridade estatal. A despeito da superficialidade com que trata o crédito, tal teoria tem o mérito de resolver de forma simples a questão do que determina o valor-de-troca do dinheiro inconversível: o que o Banco Central oferta. Neste sentido, a questão da oferta monetária é intrinsecamente conectada com a definição do que é o dinheiro: "[t]he exogeneity-endogeneity of money issue is of course intimately connected with the famous difficulty of defining precisely what is "money"' (Blaug 1995b, p.39).

Vimos no capítulo 2 que a TQM não funciona quando os agentes podem livremente converter o papel-moeda em ouro, pois a possibilidade de arbitragem garante que a oferta monetária é endógena. Contudo, com o dinheiro inconversível a coisa é distinta, pois aí não há mais um valor intrínseco que opere como um centro gravitacional (ainda que este centro seja ele mesmo móvel) e a autoridade estatal assume o controle sobre a oferta de meios líquidos. Neste caso, de oferta monetária exógena de dinheiro inconversível, a TQM funciona. Daí nossa questão: a introdução do dinheiro inconversível como moeda padrão do sistema mantém ou nega as asserções de Marx contra a TQM? Ganha a TQM, assim, algum momento de verdade?

Isto porque nos parece que o valor-de-troca do dinheiro inconversível seja determinado propriamente pela relação de sua quantidade com a quantidade de mercadorias em 
circulação, o que reabilitaria o raciocínio de Hume e de Ricardo, no sentido de que se põe mercadoria de um lado e dinheiro de outro, resgatando a cisão entre "lado real" e "lado monetário" que já criticamos no capítulo anterior a este.

A idéia central deste capítulo é antinômica: a TQM vale e não-vale. Não vale porque não apreende adequadamente a constituição contraditória do dinheiro. Mas vale porque, apesar de todos os seus problemas teóricos, revela em sua superficialidade algo da essência do dinheiro: sua essência como pura forma. Marx criticava a TQM porque esta confundia moeda e dinheiro e porque tomava o dinheiro por puro signo. Concordamos que a TQM de fato tem problemas com as determinações qualitativas do dinheiro, mas ela de fato sempre foi a expressão da essencialidade como forma pura deste objeto contraditório. É como se desde o início a TQM já quisesse pôr a descoberto a essência puramente formal do dinheiro, mas o padrão-ouro e a oferta monetária endógena a impediam de efetivamente realizar isso. O pós-1971 viria, não obstante, a dar um momento de verdade à TQM, pois aí o dinheiro é signo, desgarrado de qualquer matéria que lhe forneça valor intrínseco.

Não há dúvidas de que há problemas técnicos em se determinar a direção da causação entre oferta monetária e nível de preços, além, é claro, de barreiras por conta de aspectos ideológicos do mercado. Entretanto, há uma dificuldade fundamental no fato de que as teorias monetárias são expressas em termos lógicos, e não em termos cronológicos, o que complica a obtenção de correspondências entre efeitos de curto e longo prazos da TQM (Blaug 1995b, p.27) ${ }^{114}$.

A "TQM estrita", assim como a definimos no capítulo 2, trabalha com o teorema da proporcionalidade: no longo prazo todas as variações no estoque monetário se refletem integralmente no nível de preços $(\Delta \mathrm{M}=\Delta \mathrm{P})$, deixando os preços relativos, a taxa de juros e o produto inalterados. Portanto, como defendido pelos novo-clássicos, no longo prazo a moeda é neutra, isto é, no longo prazo a curva de Philips é vertical e a política monetária é ineficaz. Ainda assim, há uma questão irônica. A época em que a TQM foi aceita teoricamente como teoria mais adequada foi exatamente quando sua relevância

114 Além disso, há um outro problema interessante: a causação em economia não necessariamente implica que a causa preceda o efeito. Por exemplo: os agentes podem prever a variável causal e agir antecipadamente via expectativas. Assim, se logicamente a causa precede o efeito, na prática, no tempo cronológico, o efeito pode preceder a causa (Blaug 1995b, p.35). 
prática era nula. Na vigência do padrão-ouro clássico (1870-1914), para o qual o estoque de dinheiro em economias abertas era ajustado conforme o nível de preços através do balanço de pagamentos, a oferta monetária era de fato endógena e determinada pelo nível de preços, afinal a oferta de dinheiro é endogenamente determinada em um regime de câmbio fixo e com conversibilidade plena em ouro. Neste caso a crítica da Banking School é acurada. Não obstante, o problema agora é outro: quando o dinheiro é definitivamente inconversível, o que ocorre com o debate Marx contra TQM? O nosso ponto aqui é que apesar da TQM ser inválida durante o padrão-ouro tradicional, ela aí, como aparência, já revelava algo da ordem da essência, qual seja: a essência puramente formal do dinheiro ${ }^{115}$.

A primeira coisa a notar é que a diferença entre a TQM e Marx não é que este último nega que $\Delta \mathrm{M}$ implique $\Delta \mathrm{P}$, senão que isto ocorre pela determinação do dinheiro como medida de dos valores, ao invés da determinação como meio-de-circulação. A TQM, por seu turno, só enxerga o dinheiro como meio-de-circulação Carchedi (1991, p.166). Marx rejeita a TQM para o caso do padrão-ouro - quando o papel-moeda é conversível, e seu valor flutua em torno do valor do ouro, para o qual a possibilidade de inflação é limitada -, mas não para o caso do dinheiro inconversível. O Estado pode potencialmente emitir papel-moeda em quantias arbitrárias através da monetização de déficits fiscais ou através de operações de open market. Neste caso Marx concorda com a TQM no sentido de que se a oferta de papel-moeda for aumentada constantemente, haverá inflação. Dessa forma, embora papel-moeda seja um bom meio-de-circulação, não é bom como entesouramento (reserva de valor), já que seus valores-de-troca doméstico e externo (via taxa cambial) são instáveis. Instabilidade esta que deriva da ausência de uma relação direta entre oferta de papel-moeda e a acumulação de capital $^{116}$ (Saad-Filho 2002, p.96). Marx, como vemos, não rejeita por completo a TQM. Isto é, para o caso do crédito e do dinheiro inconversível, a quantidade passa a ser o critério fundamental na determinação dos seus valores-de-troca. Neste sentido, a validade da TQM deve ser considerada sob certas condições (Lapavitsas 2000).

\footnotetext{
115 Portanto, "[t]he quantity theory is, so to say, the illegitimate sideline of the classical tradition, the classical theory for unclassical fiat money” (Niehans 1987 apud Blaug 1995b, p.35).

116 Vemos, então, que o fim do padrão-ouro trouxe consigo uma instabilidade quanto aos valores das moedas, tanto domesticamente quanto internacionalmente. Em um dos itens de nosso capítulo 4 desenvolveremos nossa tese de que jaz aí a ligação lógica entre o dinheiro inconversível e a formação de capital fictício própria a ele, via mercado de derivativos financeiros.
} 
No capítulo 2 vimos como Marx claramente se aproximava dos ensinamentos da Banking School e, naquela análise, vimos que a função do dinheiro enquanto tesouro é fundamental para a regulação da quantidade de meio circulante. Contudo, essa herança teórica de Marx estava também atrelada ao ouro como dinheiro e ao ouro como mercadoria absoluta que pode ser entesourada. Agora a questão torna-se mais árdua: pode o dinheiro inconversível servir como tesouro? Ou ainda: é a oferta de dinheiro inconversível ainda regulada pelo mecanismo do entesouramento?

A resposta de Lapavitsas (2000, p.646) a esta questão é a de que o dinheiro inconversível é inadequado à função de entesouramento e, ao contrário do crédito, nada pode mudar esta inadequação. O dinheiro inconversível opera adequadamente como meio-de-circulação porque a substância do dinheiro é imaterial neste contexto, mas ele não pode adequadamente preservar valor fora da esfera de troca, pois não possui valor e nem está organicamente conectado com a acumulação de capital através do crédito. $\mathrm{O}$ poder do Estado é suficiente para permitir a mediação na circulação, mas não é suficiente para preservar valor e nem para satisfatoriamente transferir valor no tempo. Para que o dinheiro inconversível tenha essas adequações é imperativa sua conexão com o sistema de crédito. Entretanto, ressalvas devem ser feitas a esta abordagem, pois as moedas centrais do sistema monetário internacional, como o dólar, o euro e o yen, continuam a operarem como reserva de valor e tesouro. A noção de hierarquia de moedas de Eichengreen e Hausmann (2005) e Eichengreen (2000) deixa isto bem claro.

Ademais, a equação quantitativa precisa ser drasticamente modificada ao levarmos em conta o crédito como financiador do comércio. Traçando uma comparação entre Marx e a TQM, Foley (1986, p.24-25) diz que, para a segunda, variações no estoque monetário impactam proporcionalmente sobre os preços $(\Delta \mathrm{M}=\Delta \mathrm{P})$, tendo a velocidade da moeda (V) e o nível de produto (Y) tomados como dados. Neste caso a demanda por moeda é estável e, logo, não há entesouramentos (dinheiro ocioso) para ajustar a quantidade em circulação. Ao contrário, para Marx, o nível de produto e a velocidade de circulação, através da teoria do valor-trabalho, determinam os preços das mercadorias, para daí se derivar o quanto de dinheiro deve entrar em circulação, e para o qual os entesouramentos servem como mecanismo de ajuste. Com o dinheiro inconversível o problema de adaptar os meios-de-pagamento às necessidades da circulação constitui-se em um problema de ajuste do volume de crédito, ao invés de ajuste do 
volume de entesouramento (idem). $\mathrm{O}$ ajustamento da quantidade do dinheiro às necessidades da circulação é um processo complexo que envolve todas as funções do dinheiro. Em um nível mais complexo e concreto de análise, a quantidade e a velocidade do dinheiro são determinantes importantes da expressão do valor como preço (Saad-Filho 2002, p.96).

Se com o dinheiro inconversível a oferta monetária torna-se fruto de uma arbitrariedade do Banco Central, não mais sujeita a um centro atrator natural dado por um valor de produção da matéria da forma dinheiro, então - como já exaustivamente vimos em seções anteriores - vale a TQM e dela se aproxima a teoria monetária marxista: "The anti-quantity theory is in substantial agreement with the quantity theory regarding determination of the exchange value of fiat money" (Lapavitsas 2000, p.646). A exogeneidade da oferta monetária é justamente aquilo que valida a TQM e dela compartilha a teoria anti-quantitativista: "even for the anti-quantity theory, the exchange value of inconvertibe fiat money is determined through mechanisms charateristics of the quantity theory" (idem), para a qual o valor-de-troca do dinheiro inconversível é igual ao inverso do nível de preço.

No padrão-ouro, variações exógenas da oferta monetária são respondidas com entesouramentos e alterações na velocidade da moeda; mas quando o dinheiro é inconversível o mecanismo muda, tal que se aproxima da TQM: "in the case of incovnertible paper money, Marx's theory is similar to the quantity theory of money, in the same sense that the quantity of money is an exogenous variable and determines (in part) prices" (Moseley 2005, p.5). Em outro texto, Moseley (2004) vai mais fundo e mostra como no caso do dinheiro inconversível a quantidade de dinheiro passa a ser a variável independente e os preços a variável dependente. Entretanto, mesmo que assim exista uma aproximação com a TQM, a determinação dos preços pelo estoque monetário não é direta, pois há a mediação da MELT. Dessa maneira, quando o dinheiro perde por completo a ligação com sua matéria, a determinação do valor do dinheiro ocorre pela seguinte expressão: MELT = M.V.(1/L), onde M é o estoque monetário, V a velocidade da moeda e $\mathrm{L}$ a quantidade total de tempo de trabalho socialmente necessário (que em inglês atende pela sigla SNLT, social necessary labor time), sendo o valor do dinheiro o inverso da MELT (idem). 
Ainda assim, Marx ainda teria vantagens sobre a TQM, pois mostra a necessidade lógica do dinheiro, explica o nível geral de preços e os preços individuais e fornece as bases para a teoria da mais-valia e da acumulação de capital. Ou seja, ainda que o dinheiro inconversível aproxime Marx da TQM, ele mantém uma organicidade lógica das formas bem superior à sua teoria rival.

Todavia, Moseley (idem) não diz como se determina M, o estoque monetário. Ele simplesmente afirma que esta é uma variável exógena. Mas isto quer dizer que ela seja totalmente arbitrária? Existe algum $\mathrm{M}$ de equilíbrio, que não causa inflação? Se $\mathrm{M}$ for exógeno, então a MELT tem um componente claramente arbitrário e convencional. O que nos levaria a uma conclusão inevitável: de todos os autores analisados ao longo desta dissertação, nenhum deles explica efetivamente o que determina o estoque monetário de dinheiro inconversível. Lapavitsas (2000) mostra que M deve ser entendido dentro do âmbito da acumulação de capital, porém, o que ocorre quando levamos em conta o Volume III de $O$ Capital, quando justamente aparecem valores fictícios e acumulação de capital fictício? Como saber o que são as "necessidades da produção e do comércio" quando o sistema tende intrinsecamente a produzir valores fictícios? Este ponto nenhum autor aqui analisado conseguiu responder.

A Autoridade Monetária pode controlar a oferta de dinheiro nas expansões, mas não controla suas reduções nas crises. A contração da oferta monetária e, principalmente, do crédito, é determinada endogenamente. Isto é, a arbitrariedade na definição de $M$ parece depender da fase do ciclo econômico. Além do que esta oferta de meios líquidos é seguramente mais exógena no curto do que no longo prazo o que faz com que a TQM tenha mais validade no curto do que no longo prazo. Sendo que o tamanho da economia frente ao mercado mundial também influencia o grau de exogeneidade da oferta de dinheiro doméstica: quanto menor a economia, mais ela deve se enquadrar nos fluxos internacionais de capitais (Blaug 1995b, p.38). Ou seja, a pergunta não deve ser "o que determina a oferta monetária?", mas sim "o que determina a oferta monetária no longo prazo?" "117, pois é no longo prazo que nos

\footnotetext{
117 Aqui deve-se ter em mente que a queda da popularidade do monetarismo à la Friedman mostrou a perda de utilidade da tentativa de se controlar diretamente a oferta monetária. Desde então os Bancos Centrais passaram a controlar diretamente a taxa básica de juros.
} 
desfazemos das arbitrariedades do Banco Central. E, reformulando a questão principal, chegamos à pergunta mais acurada: o que determina o valor-de-troca do dinheiro inconversível no longo prazo? No curto prazo a resposta inevitavelmente remete a um bom grau de arbitrariedade. Mas no longo prazo esta determinação ainda permanece sem resposta ${ }^{118}$.

Em suma, o nosso ponto é que não é correto negar simplesmente a TQM, senão entendê-la como teoria da aparência da circulação monetária. Mas, além disso, mostrar que essa aparência já revela algo da ordem da essência: que o dinheiro é pura forma, ou seja, o dinheiro essencialmente não exige a mediação de algo material. A TQM não deve ser rechaçada pela teoria marxista, mas incorporada como momento de verdade de um movimento contraditório da forma dinheiro. A TQM, apesar de todas as suas dificuldades em apreender corretamente seu objeto, goza de um privilégio: revela a essência formal do dinheiro.

\subsection{O Dinheiro Inconversível e a Transformação dos Valores em Preços}

A teoria monetária de Marx também pode ser discutida por outro ângulo e em outro nível de abstração, qual seja: o da concorrência dos capitais. Como veremos, a questão do dinheiro inconversível não repercute somente no âmbito do Capítulo 3 do Volume I de $O$ Capital, senão que tem implicações sérias sobre a transformação de valores em preços e sobre a formação de capital fictício. Nesta seção nos ocuparemos da primeira, e deixamos para o próximo capítulo a segunda.

"The transformations of value into prices of production ... has important implications not only for Marx's analysis of the form of social labor, but also for his monetary theory. The contemporary predominance of inconvertible (valueless) paper money poses a challenge to one aspect of Marx's theory: it is not immediately clear how commodity values are

\footnotetext{
${ }^{118}$ Portanto, dizer que o dinheiro é pura forma não implica que sua determinação seja exógena. No longo prazo o dinheiro inconversível é pura forma e pode ser também endógeno.
} 
measured, and expressed as prices, if money has no intrinsic value" (Saad-Filho 2002, p.97)

Seguindo estas palavras, desenvolvemos a presente seção. Problema teórico que, caso não bem resolvido, constitui-se em séria limitação às análises da inflação e da determinação de taxas cambiais. Tais discussões dependem de uma explicação teórica satisfatória do dinheiro inconversível. E Marx deixou, como vemos, esta questão em aberto.

\subsubsection{O Problema Original e suas Pressuposições}

Nos Volumes I e II de $O$ Capital, Marx não trabalha com preços e nem com a concorrência inter-capitalista. Tais formas mais concretas somente são apresentadas no Volume III. Para apresentar a transformação dos valores em preços, Marx percorre duas etapas. A primeira é passar dos valores ${ }^{119}$ para preço de custo e da mais-valia para o lucro. A segunda é passar dos preços de custo aos preços de produção e da taxa de lucro individual para a taxa média de lucro global. Procedimento este que suscitou as mais variadas interpretações, críticas e reformulações. O "problema da transformação" pode ser assim resumido: "as mercadorias não são intercambiadas meramente como mercadorias, mas como produtos de capitais que reclamam uma participação na massa global de mais-valia, que é proporcional a sua grandeza" (Marx 1984a, p.137), para o qual o preço reflete justamente esta tensão entre particular e global; e mostra como já há algo de universal (equalização do capital global) no particular (mercadoria, um capital específico). A mercadoria é um produto do capital, uma particularização do universal.

Nosso foco aqui não é discutir o "problema da transformação", nem suas interpretações ou soluções, mas sim responder à questão: qual o lugar lógico do dinheiro sem lastro, não metálico, na transformação de valores em preços? Teria Marx ficado preso no

119 Lembremos que o determinante quantitativo do valor não é o tempo de produção, mas o tempo de reprodução. "What determines value is not the amount of labour time incorporated in products, but rather the amount of labour time necessary at a given moment" (Marx 1973, p.135). As mercadorias, incluindose aí o capital-mercadoria, são constantemente reavaliados pelo mercado de acordo com o progresso tecnológico. O valor de uma mercadoria não é, pois, determinado pelos seus custos de produção, mas sim de reprodução. Se o "estado das artes" se altera, a nova produtividade dos fatores vai impor um recálculo de todas as magnitudes dos valores, sejam eles em termos absolutos ou relativos. 
Volume III à sua tese de que o dinheiro, ainda que símbolo, tem sua substancialidade no ouro? O procedimento que conhecemos para determinar o preço das mercadorias e ao mesmo tempo o valor-de-troca do dinheiro é, fazendo como Marx, pressupor que o dinheiro seja também produto do trabalho humano. Neste caso, a determinação dos preços segue o esquema já esboçado pela teoria do valor-trabalho de Ricardo. Porém, o que ocorre quando o dinheiro abandona por completo seu vínculo ao ouro, como ocorreu após 1973, ainda permanece obscuro. Será que a transformação de valores em preços é afetada por este determinante? Logo no início do Volume 3, Marx parece operar um salto de valores para preços sem dar maiores explicações. Em um exemplo ilustrativo, ele inicia dizendo:

“[...] então o valor do produto é $=400 \mathrm{c}+100 \mathrm{v}+100 \mathrm{~m}=600$ libras esterlinas” (Marx 1984a, p.23 - ênfases nossas)

"Suponhamos que o valor produzido por um trabalhador numa jornada de trabalho social média se representa numa soma de dinheiro de 6 xelins" (Marx 1984a, p.24 - ênfases nossas)

"Suponhamos que uma jornada de trabalho de 10 horas seja igual a 10 xelins $=10$ marcos" (Marx 1984a, p.41 - ênfases nossas $)$

"Suponhamos que 100 libras esterlinas sejam o salário semanal de 100 trabalhadores" (Marx 1984a, p.114 - ênfases nossas)

“[...] o valor do dinheiro. Podemos considerá-lo constante" (Marx 1984a, p.40 - ênfases nossas)

Vemos claramente que ele passou da forma-valor à forma-libra esterlina sem qualquer comentário sobre como isso ocorreu. Marx diz que fala de valor, mas o valor aparece expresso em unidades monetárias; valor, nesse caso, não é valor, mas forma preço. Como pôde ele passar de horas-homem para libras? Ao dizer que "pressupõe" que o valor da jornada se expressa na quantia de 6 xelins, ele parece fazer o que o nosso exemplo acima fez com o dinheiro-metálico. A pergunta, desse modo, persiste: de onde 
vieram esses "6 xelins"? Vemos que toda a conversão de valores em preços depende crucialmente da expressão monetária da jornada de trabalho.

No Capítulo 9 do Volume III, sobre a formação da taxa geral de lucro e sobre a transformação de valores em preços de produção, nos são apresentados alguns conceitos novos e alguns quadros mostrando como opera a Lei do Valor através da concorrência dos capitais. Contudo, atentemos: por "Lei do Valor", Marx não quer dizer que as mercadorias são trocadas por seus valores, mas sim que o valor é um centro gravitacional para o preço: "A suposição de que as mercadorias das diversas esferas da produção se vendem por seus valores só significa, naturalmente, que seu valor é o centro gravitacional em torno do qual giram seus preços e em relação ao qual suas contínuas altas e baixas se compensam" (Marx 1984a, p.138).

Retomemos o raciocínio. Os quadros apresentados insistem na indiferença de apresentar "valores" ou "preços" indiscriminadamente, como se fosse uma questão de nomenclatura. Um bom exemplo disso é o terceiro quadro do Capítulo 9 do Volume III (Marx 1984a, p.123), no qual as formas "valor das mercadorias", "preço de custo" e "preço das mercadorias" aparecem na mesma unidade. Mas, que unidade comum é essa entre valores e preços? A resposta é imediata: "libras esterlinas", e não "horas-homem" ou "horas-trabalho".

No caso do "preço de custo", Marx opera a passagem de valor ao preço somente através de uma simples re-denominação: preço de custo de uma mercadoria = capital variável + capital constante. Na caso do "preço de produção", que depende da formação do lucro global médio, ocorre o mesmo processo de re-denominação: preço de produção de uma mercadoria $=$ preço de custo + lucro médio. A mais-valia, o lucro, os preços e os valores são todos mensurados em "libras esterlinas". A passagem de "horas-homem" para "libras" é pressuposta, e não explicitada. Ao que nos parece, a ausência da forma dinheiro mostra que o raciocínio poderia ter sido montado sem o uso das "libras" e somente com o uso das "horas-homem" como unidade de medida. O Capítulo 10 do Volume 3, no qual os conceitos de "valor individual" e de "valor de mercado" (valor médio que funciona como centro gravitacional) são introduzidos, nos mostra que todo o raciocínio entre valores e preços poderia ser muito bem apresentado como entre valores e valores, isto é, entre valores individuais e valores médios (ou valores globais), fazendo 
uso de horas de trabalho abstrato e sem qualquer alusão a formas monetárias. Marx nada diz sobre o dinheiro.

\subsubsection{O Debate Moderno Acerca da Transformação: a NI, o SUT e a MELT}

Pode-se ver, não obstante, que tal questão ainda persiste mesmo em textos bem modernos que se debruçam sobre o tema da transformação. No compêndio organizado por Freeman e Carchedi (1996), vemos que esta temática, ainda que colocada de forma distinta, é recorrente na literatura Marxista atual. Sendo evidente que tal questão somente poderia ser levantada por aqueles que viveram objetivamente o fim do dinheiro metálico em todos seus sentidos. Para aqueles que discutiram o "problema da transformação" logo após a publicação do Terceiro Volume de $O$ Capital, como fizeram Böhm-Baverk, Tugan Baranovisky e Bortkievicz, o dinheiro não metálico ainda não se fazia presente como dimensão real ou teórica..

Uma das primeiras críticas severas ao raciocínio apresentado por Marx foi feita por Bortkievicz em 1907. Como mostram Borges Neto (2002, Cap.4) e Souza (2007, p.70), tal crítica de Bortkievicz a Marx contém três argumentos fundamentais: (a) ausência de uma separação bem definida entre valores e preços; (b) ausência da transformação dos insumos; (c) cálculo inadequado da taxa média de lucro. Nosso foco aqui não é entrar nessa discussão, mas simplesmente exibir como entra a forma dinheiro não-metálico nesse problema. Como um argumento a nosso favor, a solução proposta pelo próprio Bortkievicz em relação às suas críticas ao raciocínio de Marx prova como o dinheiro era tratado totalmente como dinheiro-mercadoria: "A alternativa que Bortkievicz escolhe, porém, é outra: impor a invariância do valor da mercadoria que serve de dinheiro à transformação. Assim, o valor da mesma é suposto igual a seu preço" (Souza 2007, p.74). A solução, desse modo, foi tratar a mercadoria-ouro diretamente como ouro e como numerário. Décadas mais tarde, de acordo com as contribuições de Seton (1957), que continuou a utilizar a abordagem "simultâneo-dualista" e a expandir o raciocínio inaugurado por Bortkievicz, o problema do dinheiro é novamente tomado como pressuposto. Seton trabalha com vetores mensurados em horas de trabalho simples e 
com vetores de preços de produção, mas nada é afirmado sobre como se passou de horas de trabalho para valores monetários.

Vários críticos perceberam essa falha do sistema simultâneo-dualista em não tratar o dinheiro como valor autonomizado. Bortkievicz assume que o valor do dinheiro não varia conforme ocorre a própria transformação. Neste caso, serve o dinheiro como numerário e como condição de normalização do sistema de equações. Além disso, através de Naples (1996) e Rodriguez-Herrera (1996), observa-se como ainda existem interpretações que tratam o dinheiro como uma mercadoria de fato, sujeito ele também à transformação de valores a preços de produção. A solução de Wolff, Callari e Roberts (1982 e 1984), apesar de propor uma interessante interpretação acerca dos preços de produção como síntese concreta das esferas abstratas da produção e da circulação - isto é, de que preço e valores se determinam mutuamente -, ainda montam seu modelo expressando tanto preços quanto valores em unidades de trabalho abstrato. Inclusive, neste modelo, a própria taxa de juros é mensurada em termos de trabalho abstrato. Os autores, portanto, operam teoricamente em uma economia de trocas diretas, sem dinheiro como valor autônomo. Neste caso, os preços não são expressos em unidades monetárias, mas unidades de tempo de trabalho, assim como as variáveis medidas em valores. O único lugar para o "dinheiro” é como um simples numerário.

Em nosso entendimento, operar com um sistema de equações que somente lide com variáveis mensuradas em tempo de trabalho constitui a própria negação vulgar do que seja uma economia capitalista. Neste caso, trata-se na verdade de uma economia de escambo, onde venda e compra não são movimentos opostos. No capitalismo, ao contrário, os valores, representados por seu equivalente geral (sua forma autônoma de riqueza), são negados e conservados nos preços. Há a mediação. Compra e venda estão, pois, em oposição e mediatizadas pela forma dinheiro.

A chamada "Nova Interpretação" (NI), que se originou com os trabalhos seminais de Duménil $(1980 ; 1983 ; 1984)$ e de Foley (1982) atentam para esta insuficiência no que concerne ao tratamento da forma dinheiro. Foley (1982) explicitamente se dedica ao problema lógico do que ele chamou da determinação do "value of money", que representa justamente a associação entre determinada quantidade de trabalho abstrato e um valor monetário. 
Todavia, a NI ainda peca por pressupor o que deveria de fato explicar. Foley (1982) parte de "um conjunto de dados que, além dos preços vigentes, inclui a taxa de salários e os insumos - inclusive a quantidade de trabalho abstrato - necessários para produzir cada mercadoria" (Souza 2007, p.89). Ele parte, ao invés de valores dados - como ocorria com o sistema simultâneo-dualista -, de preços dados em aleatório, sejam eles preços que equalizem as taxas de lucro ou não. A partir desses preços iniciais dados torna-se possível estabelecer a relação entre unidade monetária e o tempo de trabalho abstrato. Assim sendo, caso as mercadorias se trocassem em relação direta aos seus valores, bastaria somente escolher qualquer mercadoria e obter a proporção entre tempo de trabalho e o seu preço. Mas com a discrepância inexorável entre valores e preços, tal procedimento não pode ser aplicado. Para solucionar isto, a Nova Interpretação define o valor do dinheiro no plano agregado, dividindo o valor em horas de trabalho da produção por seu valor monetário. Foley (1982, p.41) define o "valor do dinheiro" como "a razão entre o tempo de trabalho direto e o valor adicionado total"; a razão inversa do "valor do dinheiro" é chamada de "Expressão Monetária do Tempo de Trabalho" (EMTT) - ou Monetary Expression of Labor Time (MELT) -, medida em unidades monetárias por hora de trabalho abstrato.

Entretanto, ao fazer isso, acreditamos que Foley (1982) deu uma pseudo-solução para o problema, pois recai novamente nas críticas já feitas por Marx em seu Zur Kritik contra os teóricos que queriam igualar o total do valor produzido com o total de trabalho existente para acharem o valor do dinheiro. Além do que, ao tomarem-se os vetores de preços como inicialmente dados, não se explica como foram originalmente gerados. Como se passou logicamente de valores a preços? Esta pergunta de fato não é respondida, mesmo com o uso do "valor do dinheiro". Foley toma como dado o que deveria ter sua gênese explicitada. De onde veio logicamente o "valor monetário inicial"? O que faz a solução da Nova Interpretação parecer haver recuperado a noção de dinheiro como "bônus de trabalho", em que dinheiro troca certa quantidade de horastrabalho por valor - já duramente criticada por Marx ${ }^{120}$. Em nosso favor citamos duas conclusões a respeito da Nova Interpretação:

\footnotetext{
${ }^{120}$ Ao contrário do que entendemos, sobre o conceito de dinheiro da Nova Interpretação, Souza (2007, p.92-93) afirma que tal conceito "é compatível com formas contemporâneas do dinheiro, como a
} 
“[A] Nova Interpretação, em vez de ser um procedimento para representar a transformação, é uma interpretação específica da teoria do valor de Marx. Ela preocupa-se mais em propor definições consistentes coma idéia de que os preços são formas do valor do que em analisar a forma como as diversas magnitudes quantitativas são determinadas concretamente. [...] Nesse contexto, o problema de derivar preços a partir de valores perde o sentido, sendo mais apropriado mostrar que os preços vigentes em uma economia capitalista são compatíveis com as principais assertivas da teoria do valor-trabalho" (Souza 2007, p.92)

"[...] the NI does not involve a solution to the transformation problem, or, to put it another way, it is compatible with any pricing solution. It is simply an 'interpretation' whose formal content is a tautology arising out of the way in which the LEM (or the value of money) and the value of labor power have been defined" (Fine, Lapavitsas e Saad-Filho 2004, p.6)

A abordagem do Sistema Único Temporal (SUT), como pode ser vista em Freeman e Carchedi (1996), ou em Kliman e McGlone (1999), procuram incorporar as diversas críticas feitas aos sistemas simultâneo-dualistas e também seguem em certa medida a tradição da Nova Interpretação inaugurada na década de 1980 por Duménil e Foley. A solução encontrada tem a vantagem de ser o mais fiel possível aos escritos originais do Volume III de $O$ Capital, de trabalhar com preços e valores de equilíbrio (quando há equalização das taxas de lucro) e também de não-equilíbrio, de trabalhar com a determinação recíproca entre valores e preços (não simultaneamente, mas sequencialmente), ainda que, como no caso da Nova Interpretação, não seja "adequado referir-se ao Sistema Único Temporal como uma 'solução' para o problema da transformação, mas sim como uma interpretação da teoria do valor de Marx” (Souza 2007, p.102). E, para o que aqui é objeto de análise, o SUT herda os conceitos de “expressão monetária do tempo de trabalho” (EMTT ou MELT) e seu recíproco, o "valor do dinheiro".

fiduciária. [...] essa é a característica mais fecunda da Nova Interpretação, tendo sido adotada também pelo Sistema Único Temporal". 
No modelo proposto por Kliman e McGlone (1999), a MELT é representada pela variável $\varepsilon$, um escalar que transforma unidades monetárias em tempo de trabalho abstrato, ou seja, a expressão monetária do tempo de trabalho - ainda que assumida como constante. Hipótese que é relaxada em Kliman (2001), ao introduzir a possibilidade explícita da variação da MELT através do conceito de inflação. Pode, assim, a mesma quantidade de valor (em tempo de trabalho abstrato) ser expressa em um maior valor monetário. Ou seja, a inflação representa um aumento na MELT $(\uparrow \varepsilon)$, ou, alternativamente, uma redução no valor do dinheiro: $\varepsilon_{t+1}=(1+i) \varepsilon_{t}$, sendo i a taxa de inflação entre t e $(t+1)$.

Segundo Foley (1983 e 1997), tal apreensão da forma dinheiro via MELT dá conta tanto da moeda mercadoria (como o ouro metálico) como da moeda fiduciária sem lastro servindo de recurso teórico para a transformação de valores em preços independentemente de uma fase do capitalismo em específico. Este conceito apresentaria tal flexibilidade justamente por ser a proporção entre a quantidade de tempo de trabalho socialmente necessário despendido em certo período e o valor monetário criado no mesmo período de tempo. Se para os modelos simultâneo-dualistas o dinheiro poderia ser tanto uma condição de normalização não sujeita à própria transformação ou mesmo uma mercadoria qualquer, sujeita também à sua transformação em preço de produção, para o SUT o dinheiro é algo de diferente destas duas formas. A vantagem da MELT é sua determinação pela precificação de todas as mercadorias e pela reprodução do capital global em seu todo. Dentre as concepções existentes, destacamos as seguintes: (a) para Rodriguez-Herrera (1996, p.86), a MELT é a "razão" entre o valor do produto em unidades monetárias e quantidade de trabalho abstrato usado em sua respectiva produção; (b) para Carchedi e deHaan (1996), a MELT é um "escalar" que representa a razão entre a quantidade de dinheiro circulante e a quantidade de trabalho abstrata contida no produto; (c) Kliman (2001) define a MELT sequencialmente e a determina a partir de seus próprios valores prévios, em uma representação dinâmica da relação entre o trabalho despendido e o valor monetário adicionado.

Contudo, Marx parece dizer que a forma dinheiro é algo diferente do que uma relação entre tempo de trabalho abstrato e um "valor monetário": "The necessity of a money 
other than labour time arises precisely because the quantity of labour time must not be expressed in its immediate, particular product, but in a mediated, general product [...] Labour time cannot directly be money (a demand which is the same, in other words, as demanding that every commodity should simply be its own money [...]. [...] The truth is that the exchange-value relation - of commodities as mutually equal and equivalent objectifications of labour time - comprises contradictions which find their objective expression in a money which is distinct from labour time" (Marx 1973, p.167-169). Este trecho, retirado dos Grundrisse, parece ser uma crítica direta ao conceito moderno de MELT.

$\mathrm{O}$ argumento acima advoga que os tempos de trabalho particulares não podem ser diretamente trocados por todos os outros tempos de trabalhos particulares. A troca generalizada precisa primeiro ser mediada, assumindo uma forma objetiva diferente de si mesma. $O$ dinheiro, como objeto autônomo, realiza a passagem do particular ao geral. $O$ valor-de-troca pressupõe precisamente que nem o tempo de trabalho individual e nem o produto do trabalho individual são diretamente gerais; ambos precisam passar por uma mediação objetiva distinta de si mesmos. Seguindo Fausto (1997, p.93), o dinheiro como bônus de trabalho é um dinheiro com determinações mas sem posição, pois as funções do dinheiro são introduzidas artificialmente, sem a reflexão objetiva sendo que por reflexão objetiva entendemos a cristalização do tempo de trabalho numa mercadoria particular que introduz as leis objetivas que regulam o dinheiro, justamente por sua condição de produto do trabalho que assegura a posição e síntese das determinações do dinheiro.

Em suma, fazemos nossas as palavras de Itoh (2005) de que "an important shortcoming of the new interpretation is the absence of any theory of the exchange-value of money (p.177). Talvez isto ocorra porque a NI se concentra em relações macro-econômicas, negligenciando teorias micro de preços. Consequentemente, o valor do dinheiro está descolado da substância do valor e reinterpretado como igualmente aplicável tanto para o ouro quanto para o dinheiro inconversível, já que é uma definição ex post (idem, p.184). 


\title{
Capítulo 4
}

\section{Do Dinheiro Inconversível ao Moderno Capital Fictício}

\author{
"Numa sociedade moderna não existe nada \\ supérfluo" (LeTrosne, apud Marx 2002, \\ p.190).
}

A tarefa agora consiste em fechar o nosso argumento central. Mostraremos como a posição do dinheiro inconversível ensejou a formação de um capital fictício, a mercadoria-capital, própria a ele, para o qual os derivativos financeiros têm papel central. Derivativos estes que serão conceituados como objetos contraditórios, pois aparecem como "instrumentos" (de gerenciamento de riscos), mas que em sua essência negam-se como meio para efetivamente se colocarem como produtores de um risco abstrato, a nova medida por excelência da mercadoria-capital, do capital que se fez mercadoria, do capital que se medeia consigo mesmo por meio de um outro que ele mesmo produz e que mantém como seu momento. Os derivativos são, desse modo, mercadorias sui generis, pois é o sujeito capital que aparece como uma coisa que tem um preço e que ganha status quase de movimento infinito, cuja finalidade lhe é interior.

\subsection{O Capital Financeiro ou o Capital-Portador-de-Juros}

O capital financeiro é dinheiro que se tornou mercadoria, isto é, mercadoriadinheiro. $O$ objeto de mediação, o dinheiro, torna-se coisa mediada, mas como o meio efetivo é o próprio dinheiro, medeia-se ele consigo mesmo: "in the sphere of circulation money simply expresses and facilitates itself. Rightly called by the financial community the money markets, here money mediates itself as currency, capital, interest (at a deeper level, value) and so on" (LiPuma e Lee 2005, p.412 - ênfase nossa). 
Capital financeiro é a mediação do dinheiro consigo mesmo e, assim sendo, enquanto capital financeiro assume uma finalidade interna, com a possibilidade de se pôr como sujeito ${ }^{121}$. Aqui “a relação social está consumada como relação de uma coisa, do dinheiro consigo mesmo" (Marx 1984b, 293-294). É dinheiro que aparece como mercadoria, cujo "preço" - a taxa de juros - aparece como a mais-valia que o capital monetário proporciona em-si e para-si. De predicado do capital o dinheiro pode vir-aser sujeito, ainda que "sujeito fictício", pois opera "como se sujeito fosse" (Paulani 1991, p.154 e p.165). A apresentação do dinheiro enquanto mercadoria-dinheiro não é uma nova determinação, mas um movimento que do dinheiro faz parte quando constituído em sua plenitude: “As diferentes operações de cuja autonomização em atividades específicas se origina o comércio de dinheiro, resultam das diferentes determinações do próprio dinheiro" (Marx 1984a, p.238 - originalmente citado por Paulani 1991). A seção V do Livro III de O Capital mostra, portanto, como o dinheiro assume a aparência de que é ele próprio capital, justamente por já ter algo do infinito hegeliano, como algo que se move e se multiplica por si mesmo ${ }^{122}$.

Portanto, um dos predicados do capital encarna em si o próprio movimento. O dinheiro é tido fenomenicamente como o próprio capital, aparecendo como mercadoria-capital. Isto é, a mercadoria-dinheiro aparece como mercadoria-capital (idem, p.155), acobertando o verdadeiro sujeito do processo, que é o capital. Ou, dito de outra forma: o dinheiro, que se torna mediador e mediado, dinheiro que se relaciona consigo mesmo, é mercadoria-dinheiro, dinheiro que se apresenta como mercadoria; mas justamente por aí se apresentar como movimento cuja finalidade é interior e que dele extrai um maisvalor, toma-se o dinheiro como se fosse o próprio capital; ou seja, confunde-se o sujeito com um de seus predicados porque esse predicado em específico já contém algo do infinito que constitui o verdadeiro sujeito - e ainda mais porque esse predicado medeia-se consigo mesmo. O capital financeiro, que é essencialmente mercadoriadinheiro, aparece como mercadoria-capital, pois o predicado aparece como se sujeito fosse. O sistema capitalista, que ontologicamente é valor que valoriza, ganha efetivamente a aparência de pura sociedade mercantil (Paulani 1991, p.157), e o

${ }^{121}$ Hilferding (1981, p.234-235) emprega o termo "capital financeiro" para denotar uma totalidade que subsume todas as outras formas do capital como seus momentos. Aqui empregamos a definição usada por Chesnais (2005) de que capital financeiro é capital-portador-de-juros.

${ }^{122}$ Lapavitsas não percebe isso: "money itself is never offered for sale; it is always used to buy. [...] only money buys and is never sold" (2005, p.98). A noção de capital-portador-de-juros é exatamente o melhor contra-argumento. Dinheiro compra e é comprado também. 
excedente social se mostra como propriedade de uma coisa. Todo o processo social resume-se como propriedade de uma coisa, de um objeto. Neste processo, o dinheiro é uma auto-posição que só existe se não existir (parece pôr-se por si, mas é de fato posto por outro), ou auto-posição como pressuposição, já que o seu devir como sujeito nunca chega a se realizar. Sinteticamente colocado, o capital financeiro é a mediação - o dinheiro - que alcança tudo, até o próprio dinheiro, e se interverte, pois aí mediação não é mais. É mediação que medeia até a si própria; é sua posição excessiva que o inverte. O dinheiro se nega para afirmar-se como mercadoria, e é assim que se realiza como dinheiro. A posição excessiva do valor o inverte em capital; a posição excessiva do dinheiro o inverte em mercadoria-capital, capital-portador-dejuros: "As capital, money thus also appears posited as a relation to itself mediated by circulation - in the relation of interest and capital" (Marx 1973, p.217 - ênfase nossa). Em ambos os casos a posição plena nega a coisa. Assim, quando o dinheiro como mediação alcança tudo, até ele mesmo, se efetiva plenamente como dinheiro, mas justamente aí ele não é mais dinheiro, senão mercadoria-dinheiro. O dinheiro só realiza a sua essência negando-se (Paulani 1991, p.164-166). Portanto, o dinheiro enquanto objeto tem a capacidade de personificar o capital, de agir como se ele próprio fosse, e esconde o real sujeito. O capital é, como vemos, um movimento que se expressa por meio de um objeto. O dinheiro, ainda que pareça, não age por si (idem, p.170).

A autonomização da forma capital financeiro, ou capital-portador-de-juros, também já está presente na autonomização da forma dinheiro e na negação de sua determinação como moeda: "Money in its third quality, as something which autonomously arises out of and stands against circulation" (Marx 1973, p.226). Cujo desenvolvimento conduzirá à "antithesis between the real needs of production and this supremacy of money" (idem, p.233). Deve-se deixar claro, desde o princípio, que todas as contradições dos sistemas monetário e financeiro são desenvolvimentos das contradições da mercadoria como existência dupla: "All contradictions of the monetary system ... are the development of the relation of products as exchange values, of their definitions as exchange value or as value pure and simple" (idem, p.152). Assim, o segredo da autonomização do capital financeiro parece ter sua origem na passagem lógica da forma moeda à forma dinheiro, na sua passagem de intermediário à fim em-si mesmo. Posto em outros termos, diríamos que a autonomização é o distanciamento lógico entre forma do valor e o seu suporte; ou melhor, é um processo em que as pressuposições históricas se tornam pressuposições 
internas sempre repostas pelo movimento do capital: autonomização $=$ interiorização das pressuposições (Fausto 1987b, p.327) ${ }^{123}$.

\section{Lembremos que o capital-portador-de-juros não necessariamente tem de dirigir-se}

para o capital produtivo: "the further advance of interest-bearing capital by the credit system need to be directed exclusively towards real capitalist accumulation but also towards other activities not productive of surplus value" (Itoh e Lapavitsas 1999, p.61). O capital portador de juros surge a partir do momento em que, pela posição do dinheiro como capital, qualquer soma de valor adquire o caráter de capital possível, sem seu necessário ingresso na valorização produtiva. O valor será emprestado como capital pelo seu proprietário, quer este valor seja usado ou não como capital. Sua autonomização advém do fato de, apesar de ser uma dedução da massa de excedente, não tem necessariamente de se dirigir para a produção de mais-valia. O capital financeiro pode perfeitamente, por exemplo, encaminhar-se para a expansão da dívida pública e para o financiamento do Estado e salários, bem como pode ser destinado à renda do trabalhador através do crédito ao consumidor, sem relação direta com o valor gerado (Teixeira 2007). O Estado, neste caso, tributa o capital produtivo e as rendas dos agentes e aplica parte de seu orçamento com pagamento de juros e de amortizações. Temos, portanto, uma mediação a mais entre mais-valia e juro, ainda que o último derive do primeiro. Em outros termos, o conceito de autonomização significa que mais mediações foram introduzidas no processo. A autonomização do capital financeiro evidencia que mais mediações existem entre sua origem a partir do excedente social e sua aplicação pelos agentes.

Capital financeiro não se confunde com o capital bancário. Este último é uma parcela do primeiro. A propósito, os recentes estudos de Chesnais (2002 e 2005) nos têm revelado que apesar da maior dinâmica da "financeirização", a parcela dos bancos neste processo tem sido relativamente substituída pela atuação de instituiçõos financeiras não-bancárias, como investidores institucionais, fundos de hedge, fundos

123 “[...] como resultado constante dele é seu pressuposto constante” (Marx 1984a, p.267). "Assim como a transformação de dinheiro e de valor em geral em capital é o resultado perene, sua existência como capital é o perene pressuposto do processo de produção capitalista” (Marx 1984a, p.283). "[...] a força de trabalho somente afirma sua potência criadora de valor quando é ativada e realizada no processo de trabalho; mas isso não exclui que ela em si, potencialmente, como capacidade, seja atividade criadora de valor e, como tal, não provenha primeiro do processo, mas seja antes pressuposto dele" (Marx 1984a, p.285). 
mútuos e sociedades seguradoras. No mundo pós-Bretton Woods, dominado pelas fianças diretas e pela securtização, devemos tomar cuidado em não extrapolar a importância das instituições bancárias quanto representantes do capital-portador-dejuros. O que, em parte, é uma negação das assertivas de Hilferding (1981) no começo do século XX, para quem bancos e grandes empresas formariam o que ele denominou de capital financeiro. Chesnais (idem) aponta que os bancos tiveram seu progresso obstaculizado pelo recente desenvolvimento de um sistema que tende a reduzir as intermediações bancárias, principalmente via emissão de commercial papers e títulos securitizados, dinâmica por ele denominada de "desintermediação financeira", que denota justamente a abertura das operações de empréstimo, antes reservadas aos bancos, a todo o tipo de investidor institucional. As "finanças diretas", típicas da década de 1990 em diante, são a forma securitizada do capital financeiro, em que predomina o crédito lastreado em securities ou título negociáveis diariamente no mercado ${ }^{124}$.

Os bancos, por sua vez, também mudaram sua forma de atuação. Entre a década de 1930 e a de 1960, quando vigorara o chamado Glass-Steagle Act, um dispositivo que separava os bancos comerciais dos grandes bancos de investimento, das corretoras e dos saving and loans, a intenção era segmentar o mercado com a finalidade de impedir que os bancos comerciais, que são emissores de dinheiro, se envolvessem com posições no mercado de capitais. A desregulamentação da década de 1970 revogou tal mecanismo, fazendo com que os bancos entrassem em mercados dos quais antes encontravam-se apartados.

\footnotetext{
${ }^{124}$ Sobre a nova economia que emergiu após a década de 1970, diz Chesnais (2005, p.39) que "a dívida pública permitiu a expansão dos mercados financeiros [...] ela é o pilar do poder das instituições que centralizam o capital portador-de-juros".

Além disso, a moderna forma de empresa, em que a separação da propriedade do capital e a gerência é completa, não seria ela mesma um desdobramento da própria forma contraditória da mercadoria, cuja essência é a autonomia do valor (riqueza abstrata) em relação ao seu suporte (matéria específica)? Em outras palavras: a separação gerência-acionistas (da qual emergem os problemas de agência, que como aparência são postos como uma questão de gerenciamento) não poderia ser entendida como decorrência lógica necessária da oposição fundamental entre valor e valor-de-uso, em que os vários momentos do capital nos mostram que há um tendência essencial da riqueza abstrata em se separar das matérias particulares? Assim como dito explicitamente no primeiro item do nosso primeiro capítulo, para nós Marx mantém a noção de modernidade hegeliana como um momento de cisão entre universal e particular. No caso presente isto se efetiva como uma tendência ao desgarramento da riqueza universal em relação às matérias particulares através, aqui, da cisão entre propriedade do capital (acionistas) e gerência do capital (administradores). Cisão esta que é fruto de um desenvolvimento lógico da cisão já posta na forma mercadoria entre valor de valor-de-uso. À pergunta "qual é a essência do capitalismo?" deveríamos então responder: a essência do capitalismo - assim como a essência da modernidade para Hegel - é a separação entre universal e particulares, ainda que o particular seja o modo por excelência de realização do universal.
} 


\subsection{O Sistema Financeiro como Intermediário: Uma Crítica Dialética}

\subsubsection{Marx a Favor de Keynes}

A proposição de Keynes de que a taxa de juros é determinada no mercado monetário, e não no mercado de fatores, parece já ter respaldo nos escritos marxistas da década de 1870. A taxa de juros, para Marx, que se apresenta sempre como taxa geral de juros, é resultante da oferta e da demanda por dinheiro. Assim como para Keynes, Marx diferencia dinheiro de capital, e não identifica, como fazem alguns, demanda por dinheiro com demanda por capital. Ao criticar as posições de Overstone, isto é, as posições do currency principle, Marx deixa isto evidente:

"A afirmação trivial de que a taxa de juros de mercado é determinada pela procura e oferta de capital (de empréstimo) é misturada por Overstone, de maneira astuta, com sua própria suposição de que o capital de empréstimo é idêntico ao capital em geral" (Marx 1984b, p.48)

"Se procura e oferta de capital monetário, as quais determinavam a taxa de juros, fossem idênticas à procura e oferta de capital real, [...], o juro deveria ser alto e baixo ao mesmo tempo" (Marx 1984b, p.50).

"Procura e oferta de capital de empréstimo seriam idênticas à procura e oferta de capital em geral [...] se não houvesse prestamistas de dinheiro e em seu lugar os capitalistas que emprestam estivessem de posse de maquinaria, matérias-primas etc. e as emprestassem ou alugassem [...] aos capitalistas industriais que, eles mesmos, são proprietários de uma parte desses objetos. Nessas circunstâncias, o oferta de capital de empréstimo seria idêntica à oferta de elementos de produção para o capitalista industrial e de mercadorias para o comerciante" (Marx 1984b, p.50).

“[...] errou Overstone ao identificar a procura por capital monetário emprestável (ou antes os desvios da oferta da mesma), tal como ela se 
expressa na taxa de desconto, com a procura por 'capital' real. A afirmação de que os preços das mercadorias são regulados pelas flutuações no montante de currency oculta-se agora por trás da frase de que as flutuações na taxa de desconto expressam flutuações na procura de capital físico real, em contraste com o capital monetário" (Marx 1984b, p.75-76)

Para Marx, portanto, e assim como ocorre em Keynes, o juro é um fenômeno monetário, e não físico ou "real”.

Não percebe Overstone que direitos sobre dinheiro valem tanto como se o dinheiro mesmo fossem - o que não ocorre com as mercadorias ordinárias (afinal, um direito sobre um automóvel não leva uma pessoa a lugar algum). Ao contrário delas, um depósito, ainda que seja apenas um direito sobre dinheiro de curso legal, serve aos mesmos propósitos do que se o dinheiro de fato fosse: "these bank notes and deposits will circulate like gold dollars" (Fisher 1922, Cap.3, §1). Dinheiro e direito sobre dinheiro exercem o mesmo papel. O que mostra a inadequação de tratarmos o sistema creditício como se o crédito fosse um somatório de fundos existentes, formados a partir de um suposto ato de abstenção de consumo, e do empréstimo desta "poupança" aos mutuários. Portanto, é muito mais realista dizer que os bancos produzem crédito, que eles criam depósitos ao concederem empréstimos, em lugar de afirmar que emprestam os depósitos monetários a eles confiados. Henry Thornton, como vimos no capítulo 2, já sabia no início do século XIX que as expansões creditícias se validam ex post. Quadro que ficaria ainda mais evidente com a posterior afirmação por parte de Fisher de que "bank deposits are as easy to understand as bank notes, and what is said in this chapter of bank deposits may in substance be taken as true also of bank notes. The chief difference is a formal one, the notes circulating from hand to hand, while the deposit currency circulates only by means of special orders called 'checks'. [...] And the principle governing bank notes is the same as the principle governing deposit rights” (Fisher 1922, Cap.3, §1).

Ou seja, os depositantes, ou supostos "poupadores", não devem receber rótulos por funções que não exercem de fato. Eles são tidos como "poupadores" quando na verdade nem poupam e nem desejam fazê-lo; e são tratados como se influíssem na 
“oferta de crédito", tarefa que de fato também não realizam. "[N]em mesmo em regime capitalista se segue daí que o campo de ação do capital, a escala da produção, em seus limites absolutos, dependa do montante do capital-dinheiro em funcionamento" (Marx 2000, p.403) ${ }^{125}$. Mas seriam ainda necessários alguns anos para que Keynes explicitasse que tal mecanismo de criação de depósitos via empréstimos bancários tem o papel de financiar investimentos sem que haja uma poupança prévia em montante igual ao emprestado; isto é, como os bancos podem emprestar magnitudes acima dos supostos fundos existentes criados a partir das decisões individuais de poupança ${ }^{126}$.

\subsubsection{A Aparência Necessária do Sistema Financeiro}

Apresentemos de início, em termos sucintos, as duas teorias que aqui nos servirão de alicerces:

(a) Teorias do Sistema Financeiro como Simples Intermediário: os bancos são intermediários que "reciclam" fundos ociosos que foram poupados por certos indivíduos e que agora serão usados por outros. É o depósito que permite o empréstimo. Isto é, a poupança é pré-condição. Aqui o dinheiro é meio e apreendido como fluxo ${ }^{127}$;

(b) Teoria do Dinheiro Endógeno: bancos podem iniciar o processo de acumulação pela concessão de crédito criado ex nihilo, ex novo, o qual volta como depósito aos bancos. É, portanto, o empréstimo que cria o depósito, e a

${ }^{125}$ Ou também: "A primeira circunstância, a de o capital ter de ser adiantado sob a forma dinheiro, não fica eliminada com a forma assumida pelo dinheiro, a metálica, a de crédito, a simbólica etc. A segunda circunstância em nada se altera com o meio financeiro ou a forma de produção que possibilitam retirar trabalho, meios de subsistência e meios de produção, sem lançar de volta na circulação qualquer equivalente" (idem, p.406).

${ }^{126}$ Como propõe Oreiro (2001, p.131-132), a abordagem keynesiana não centra o seu argumento no fato da taxa de juro ser determinada no mercado monetário, senão que deseja distanciar-se da teoria dos fundos emprestáveis de Wicksell e Robertson. Se para estes últimos o que determina a taxa de juros são os níveis planejados de poupança e investimento, para a teoria da preferência pela liquidez é a diferença entre investimento planejado para um período e o investimento realizado no período anterior que tem influência direta sobre a formação da taxa de juros.

${ }^{127}$ Poderíamos também chamar esta abordagem de "teoria convencional", já que se encontra consolidada em vários livros-textos de economia. Como exemplo citamos o manual de Introdução à Economia de Mankiw (tradução da segunda edição norte-americana de Principles of Economics de 2001): "Em todo caso, seu investimento ... está sendo financiado pela poupança de alguém” (p.555); "o sistema financeiro transfere os recursos escassos da economia dos poupadores (pessoas que gastam menos do que ganham) para os tomadores de empréstimo (pessoas que gastam mais do que ganham" (p.556); "essas instituições financeiras servem a um mesmo objetivo - transferir os recursos das mãos dos poupadores para as mãos dos tomadores de empréstimo" (p.561). 
poupança é um resultado. O dinheiro, apreendido como estoque, não opera como intermediário. Os bancos não são intermediários, mas transformadores de ativos não-monetários em direitos sobre dinheiro ${ }^{128}$.

A nossa tese é a de que esta divisão entre teorias do sistema financeiro como simples intermediário e a teoria do dinheiro endógeno é justamente a divisão que Marx opera entre dinheiro enquanto moeda e dinheiro enquanto dinheiro. A teoria do sistema financeiro como intermediário entende o dinheiro enquanto moeda, meio-decirculação, onde somente se empresta o que se poupou previamente. A teoria do dinheiro endógeno trabalha, por sua vez, com o dinheiro enquanto dinheiro, meio-depagamento em especial, onde se cria a oferta com base na necessidade e onde o dinheiro é algo mais do que meio-de-circulação. Se para a primeira o sistema financeiro é um intermediário, assim como justamente a moeda é meio, para a segunda os bancos são adiantadores de um poder de compra ainda não existente - isto é, não são intermediários -, exatamente assim como os meios-de-pagamento são a negação da circulação, transformando o que era meio em finalidade.

Portanto, ambas estas teorias estão contempladas nas determinações da forma dinheiro de Marx: a teoria convencional (dinheiro como moeda) como aparência da circulação e a teoria do dinheiro endógeno (dinheiro como dinheiro) como essência da circulação. Dessa forma, se os bancos de fato criam dinheiro ex nihilo, eles aparecem como o contrário disto, como intermediários que só emprestam o que outro poupou previamente. Exatamente como o dinheiro aparece inversamente ao que é em

\footnotetext{
${ }^{128}$ Há ainda uma interessante e inconclusa discussão sobre qual o poder efetivo do sistema financeiro em criar meios líquidos. Fontana (2003) mostra que a atual discussão dentre as teorias do dinheiro endógeno se divide entre o "accomodationist approach" e o "structuralist approach". A primeira abordagem, atribuída a autores como Kaldor, Weintraub, Lavoie, Moore, Rochon, Rogers e Smithin, entende que a oferta de crédito tem elasticidade-juro infinita; isto é, a provisão de crédito pelo sistema financeiro não se restringe pela existente disponibilidade de poupança. A segunda, defendida por autores como Dow, Chick, Minsky, Rousseas, Arestis, Howells, Palley, Sawyer e Wray, entende que o sistema financeiro não pode acomodar totalmente a demanda por empréstimos a uma dada taxa de juros, pois estão em operação fatores institucionais que restringem a lucratividade e a capacidade da expansão endógena do crédito. Em termos bem sintéticos, a visão estruturalista advoga que o mecanismo de oferta creditícia é algo mais complexo do que o imaginado pela visão acomodacionista, afinal o sistema financeiro, ao ofertar mais empréstimos, altera a composição e o tamanho de seu portfolio (o que envolve decisões estratégicas) e, além disso, os bancos operam segundo restrições impostas pelas políticas monetárias do BC, o qual também funciona restrito por metas de inflação, pelo câmbio e por outros fatores que o impedem de perseguir uma política totalmente acomodacionista. Sobre este mesmo tema ver também Itoh e Lapavitsas (1999, p.234-245).
} 
essência: aparece como meio quando objetivamente se põe como fim; nega o que na essência já foi posto ${ }^{129}$.

Advogamos, assim sendo, que a essência e a aparência do sistema financeiro decorrem propriamente das determinações da forma dinheiro: o que é um fim se apresenta como um meio. A relação essência/aparência do sistema financeiro duplica a relação essência/aparência do dinheiro. Essência (dinheiro como fìm e o sistema financeiro como não-intermediário) e aparência (dinheiro como meio e sistema financeiro como intermediário) se negam e se determinam em uma relação contraditória. $\mathrm{Ou}$ seja, o sistema financeiro é contraditório porque sua essência nega sua aparência, e viceversa.

A melhor constatação do paradoxo do sistema financeiro é a própria figura de Wicksell, que ao tentar apreender o dinheiro enquanto meio-de-circulação, enquanto "moeda neutra", acabava por obter teoricamente o contrário do que desejava, apreendendo-a como "moeda não-neutra", justamente por sua determinação de dinheiro enquanto meio-de-pagamento. Este é um caso clássico em que a aparência se mostra como aparência invertida de sua essência mesma. Wicksell, ao não dizer o dinheiro enquanto forma contraditória, acabou por sofrer em seu discurso a contradição do objeto ${ }^{130}$.

A questão, em outras palavras, não é que a teoria do sistema financeiro como intermediário é simplesmente errada, mas que ela é a expressão necessária de uma essência (essência que, por sua vez, é captada pela teoria do dinheiro endógeno) que a nega mas que também a conserva como momento, ainda que como momento negado. Portanto, a existência de uma teoria não é fortuita, senão precisamente a expressão teórica de uma determinação posta pelo próprio objeto dinheiro. Se a aparência do sistema financeiro coube às teorias que o entendem como simples re-alocador de

\footnotetext{
${ }^{129}$ Bellofiore (2005) não tem a mesma idéia que aqui desenvolvemos, mas ele atesta que "Marx initially puts forward a view of banks as mere financial intermediaries" (p.137), onde se empresta o que se depositou; mas, inversamente, em seguida Marx "offers in other pages [the theory that] bank credit is advanced without any contraint coming from prior savings, either real or monetary” (p.138), onde os bancos não são mais intermediários, mas sim transformadores de ativos não-monetários em direitos sobre dinheiro.

${ }^{130}$ Sobre esta questão da contradição passar do objeto ao discurso, ver Fausto (1987a e 1987b) e Paulani (1991).
} 
recursos já existentes - sendo que a oscilação teórica de Wicksell ${ }^{131}$ é, ela mesma, uma forte evidência de como já algo da essência jaz na aparência -, e se a essência coube a Keynes, Minsky e seus seguidores modernos, caberia então à teoria marxista a articulação do todo e a posição de ambos os momentos como necessidades lógicas de uma realidade contraditória.

Este é o cerne para a discussão sobre os determinantes da taxa de juros. Para a teoria convencional - que se esposou em parte da teoria da taxa natural de Wicksell -, a taxa de juros é determinada pelo cruzamento das funções de poupança e investimento, medidas ambas como fluxos. Assim, esta taxa é um reflexo de dois elementos: (a) de que o dinheiro é moeda, meio-de-circulação, meio de troca; (b) de que os bancos são intermediários financeiros e que, portanto, não criam moeda ${ }^{132}$. E pelo que vimos acima, (a) e (b) são dois lados da mesma coisa: dizer que dinheiro é meio é o mesmo que dizer que o sistema financeiro é um meio. Então, para esta teoria, a taxa de juros é formada em um mercado em que os componentes financeiros e monetários são puros intermediários. Por outro lado, para pós-keynesianos, a taxa de juros decorre e dois fenômenos: (c) de que o dinheiro (neste caso, crédito) não é meio; (d) de que o sistema financeiro cria um poder de compra para além de seus depósitos existentes. Neste sentido, o dinheiro não é simples intermediário, mas algo produzido conforme dele se necessite. A taxa de juros vai aparecer, então, não como resultado de equilíbrio entre fluxos de investimento e poupança, mas a partir do estoque de riqueza ${ }^{133}$. Para Marx, diríamos que a taxa de juros se determina assim como para Keynes e Minsky, mas que se apresenta aparentemente como a teoria convencional a hipostasia.

Este discussão lembra um pouco uma das críticas que Hegel fez a Kant quanto ao conhecimento. Se Kant apartou o sujeito do objeto e com isso hipostasiou o conhecimento como um instrumento, como um meio, para o qual o conceito é uma

\footnotetext{
${ }^{131}$ A oscilação de Wicksell a qual nos referimos é o fato deste autor oscilar entre a apreensão do dinheiro como simples meio (como moeda neutra) e como fim em si mesmo. Entendemos aqui que Wicksell oscila justamente porque o seu objeto oscila.

${ }^{132}$ Vale lembrar que Wicksell sabia muito bem que o sistema financeiro cria sim meios líquidos, podendo ele ser classificado neste aspecto como um precursor das teorias do dinheiro endógeno.

133 Autores como Hicks, Lerner, Tsiang e Patinkin chegaram a propor que a abordagem dos fundos emprestáveis de Wicksell não diferiria em essência da preferência pela liquidez de Keynes, afirmando que ambas estas teorias chegavam a resultados equivalentes. Entretanto, ainda que aqui coloquemos Wicksell ao lado de Keynes no que tange à endogeneidade do dinheiro, concordamos com Oreiro (2001) que estas duas abordagens têm diagnósticos teóricos bem distintos a ponto de invalidarem tentativas modernas que propõe uma suposta equivalência entre elas.
} 
unidade sintética de percepções, Hegel o reprovou com sua prova ontológica: objeto e sujeito parecem imediatamente estar separados, mas a fenomenologia mostra que não, pois a pressuposição se revela também como pertinente ao objeto e a posição também atinente ao sujeito. Dessa forma, em Hegel o conhecimento perde o seu caráter instrumental, intermediário, de meio. Como vimos no primeiro capítulo, o conceito produz seus objetos, o conceito produz os objetos para o conhecer; ou, como diz Minsky: "money is an end product of financial arrangement" (Minsky 1982, p.17 ênfase nossa). Isto significa dizer que a teoria convencional assume uma posição como a de Kant. Marx, assim como Hegel, usa a prova ontológica para mostrar que o que aparecia como meio se produz como fim.

Esse parece ser o caso do sistema financeiro. Marx está chamando a atenção, como queremos mostrar, para o fato de que nem o dinheiro é de fato meio nem os bancos são intermediários. Poderíamos então asseverar que para a abordagem convencional, mercadoria e dinheiro estão apartados (assim como estão apartados objeto e sujeito em Kant) e, por isso, o sistema financeiro aparece como um intermediário (assim como o conhecimento é um meio para Kant). Para Marx, a mercadoria produz logicamente o dinheiro, o qual se torna seu "sujeito". Mercadoria e dinheiro não estão apartados (assim como sujeito e objeto em Hegel), e o sistema financeiro produz dinheiro e, portanto, não é intermediário (assim como o conceito, em Hegel, produz seus próprios objetos).

Entretanto, tanto para a teoria convencional quanto para os pós-keynesianos parece haver um abismo entre mercadoria e dinheiro. Para a primeira o abismo é tão grande que ali o dinheiro não importa. Para os segundos, o abismo é menor, mas ainda assim separa mercadoria de dinheiro, já que se mantém a dicotomia entre lado real e lado monetário. A propósito, a própria pergunta se "variáveis nominais afetam variáveis reais" já pressupõe tal dicotomia. Para Marx isso não ocorre: mercadoria e dinheiro estão sempre juntos, sejam como formas opostas, sejam como predicados lógicos do capital, ou como relação predicado-“sujeito" quando da mercadoria-capital.

Dessa forma, a determinação da taxa de juros e a operacionalidade do sistema financeiro parecem também remeter a questões de ordem da gramática filosófica. Não seria essa uma boa maneira de mostrar como a teoria convencional se conforma à lógica do 
entendimento? Não seria a taxa de juros, em sua aparência, fruto também da lógica das representações?

Para Keynes e Minsky, o banco produz aquilo que ele pressupõe, produz seus próprios pressupostos: o empréstimo produz o depósito, ainda que em sua origem histórica tenha ocorrido inicialmente o contrário. Para Hegel, o conhecimento produz seu objeto, produz o que “deveria” pressupor, produz seus pressupostos. Não é somente que o resultado segue das condições, mas que as condições seguem dos resultados. O que na aparência é condição, a essência já negou como resultado.

Em suma, a tese deste item é a de que se o approach convencional se atém somente ao momento da aparência e se os pós-keynesianos se atêm somente ao momento da essência, é a teoria marxista e a lógica dialética que podem dizer o todo, incluindo ambos como seus momentos lógicos. De um lado temos que a teoria convencional não reconheceu o momento da essência. Mas de outro, é também verdade que os pós-keynesianos não reconhecem o momento da aparência, pois eles negam simplesmente seus adversários, não a conservando como seu momento negado. É a dialética marxista que permite negar a teoria convencional conservando-a como aparência negada e, ao mesmo tempo, negar a teoria pós-keynesiana conservandoa como essência negada pela aparência. Sendo que esta forma de apreender o sistema financeiro, como advogamos, já se encontra em forma embrionária nas próprias determinações do dinheiro.

Hegel colocava este movimento em outros termos: "o vir-a-ser da ciência em geral ou do saber ... não terá nada a ver com o entusiasmo que irrompe imediatamente com o saber absoluto ... [que] descarta os outros pontos de vista, declarando que não quer saber deles" (2002, §27, p.40-41). Sim, pois, queremos saber deles, como momentos da verdade, onde "cada momento é necessário ... [e] cada um deles é uma figura individual completa" (idem, $§ 29$, p.42).

Discussão esta que agora nos levará aos itens a seguir, que mostrarão de início que o capital fictício, se emerge logicamente da forma capital financeiro, em seu evolver opera uma inter-versão, transformando o que era pré-condição em resultado. Neste sentido, veremos que o valor fictício pode ser entendido como um vir-a-ser-valor, 
em que o valor fictício produz o seu suporte, o valor real de fato. Ou seja, ligaremos o que agora discutimos com o fato de que o capital fictício parece dizer que se a forma emergiu do suporte, a forma passará a recriar seu suporte, tornando-se, assim, forma autonomizada. O financiamento tem, portanto, uma constituição contraditória entre sua essência e sua aparência: a operação de crédito é essencialmente uma operação em que a forma cria o seu próprio suporte, mas que aparece como o contrário disto, como uma operação em que a forma deriva do suporte. Mas é somente no movimento completo, apreendido com todos os seus momentos, que temos a verdade dele.

\subsection{A Constituição Lógica do Capital Fictício}

\subsubsection{Do Valor ao Valor Fictício e Sua Inter-versão: o Valor Fictício como Vir-a-Ser-Valor}

O conceito de capital fictício já está presente de forma embrionária no conceito de capital-portador-de-juros:

"Mesmo supondo-se que a forma em que existe o capital de empréstimo seja meramente a de dinheiro real, ouro ou prata, da mercadoria cuja matéria serve de medida dos valores, ainda assim uma grande parte desse capital monetário é sempre necessariamente apenas fictícia, isto é, títulos sobre valores" (Marx 1984b, p.43).

“A acumulação desses direitos, segundo o pressuposto, deriva da acumulação real, isto é, da transformação do valor do capital-mercadoria etc. em dinheiro; não obstante, a acumulação desses direitos ou títulos difere, como tal, tanto da acumulação real, da qual deriva, quanto da acumulação futura (do novo processo de produção), que é mediada pelo empréstimo de dinheiro" (Marx 1984b, p.44). 
O capital fictício é, assim, figura logicamente derivada da figura do capital financeiro. A “maior parte do capital bancário é, portanto, puramente fictícia” (idem, p.13) ${ }^{134}$. Se recordarmos o que já dissemos nas seções anteriores sobre o capital monetário, sabemos que este faz com que cada rendimento monetário regular apareça como juro de um capital, quer ele advenha de fato de um capital ou não. Se o juro pago parece advir de um capital, mas o mesmo não existe efetivamente como capital, este se torna, desse modo, capital fictício. Em outras palavras: capital fictício pressupõe o capital financeiro, e o capital financeiro já é forma embrionária do capital fictício.

Em termos sucintos, capital fictício é o não-capital que aparece como capital. Essencialmente não é capital, mas fenomenicamente é. Segundo os escritos originais de Marx, três elementos se somam para produzir o capital fictício:

(i) Não representa capital algum: os rendimentos e juros obtidos não são deduções de qualquer mais-valor gerado, pois não há capital para ser valorizado. O que ocorre é mera distribuição do excedente já gerado em outra esfera. São "duplicatas de papel de capital extinto", funcionando como capital para seus proprietários, já que são mercadorias vendáveis e são também potencialmente capital. O melhor exemplo aqui é a dívida pública, cujos pagamentos periódicos serão trazidos a valor presente pelo princípio da capitalização;

(ii) Pode representar parcialmente algum capital real: mesmo que os papéis tenham algum tipo de lastro em uma valorização real, em uma produção efetiva de excedente, eles são tratados como se fossem mercadorias e, portanto, têm seus preços cotados de forma peculiar no mercado - como ocorre com as ações. Nesse caso, o preço de mercado se autonomiza em relação ao seu valor, pois passa a levar em conta as expectativas sobre o futuro, e não só sobre o valor de fato realizado. Seu preço pode cair ou subir independentemente do valor real que deveriam representar. Ademais, ainda que seu valor ou seu rendimento fossem tomados como dados fixos e regulares, seu preço de mercado variaria com oscilações na taxa de juros; portanto, é rendimento capitalizado. No

\footnotetext{
134 Schumpeter (1955, p.317) mostra que tais formas de capital já existiam historicamente desde os tempos dos escolásticos dos séculos XV e XVI
} 
que concerne às ações, elas fornecem direitos a certa parte do mais-valor produzido, mas não dispõem sobre o capital total;

(iii) Pode originalmente já ter representado um capital real, mas que em seu circuito próprio já apagou esta origem. Como é o caso de empréstimos via criação de crédito. Os empréstimos tornam-se colaterais de outros empréstimos e assim sucessivamente, até o ponto onde não se descobre mais qual o ponto de origem das alavancagens.

Nos Grundrisse, o termo "capital fictício" somente aparece uma única vez e relacionado ao crédito. Em um trecho dedicado à idéia de que o tempo de circulação do capital é um fardo, um mal necessário à produção, diz Marx que uma das tendências da produção é reduzir ao máximo este período que não gera valor algum, sendo esta tendência muito importante na criação de instrumentos de crédito. Diz ele então: "[C]redit is then also a form in which capital tries to posit itself as distinct from the individual capitals, or the individual capital [tries to posit] itself as capital as distinct from its quantitative barrier. But the highest result it achieves in this line is, on one side, fictitious capital; on the other side, credit only appears as a new element of concentration, of the destruction of capitals by individual, centralizing capitals" (Marx 1973, p.652). Primeiramente vamos fazer uma distinção sobre o crédito: no nível da relação entre trabalho e capital (do “capital em geral”), o crédito é dinheiro enquanto meio-de-pagamento; já no nível da concorrência dos capitais (próprio ao Volume III), o crédito é o capital-portador-dejuros, mercadoria-dinheiro. Na citação acima Marx está claramente asseverando sobre a concorrência dos vários capitais e, portanto, o crédito é aí capital-portador-de-juros. Assim entendido o texto, entendemos que a forma capital financeiro se mostra como capital fictício, pois é dinheiro, crédito, criado "do nada", ex nihilo; é uma moeda privada criada por um banco que vale como dinheiro e cria um poder de compra antes inexistente. Com isso o capital individual que recebe o crédito pode então comandar uma soma de capital-dinheiro, capital monetário, maior do que o seu capital produtivo existente. Essa diferença, que possivelmente não mais existirá quando o volume do capital produtivo crescer por conta da nova produção em maior escala, Marx chama de "capital fictício", com o qual o capital individual tenta ultrapassar suas próprias barreiras quantitativas. 
Essa passagem dos Grundrisse nos leva à pergunta inevitável: o capital fictício cria valor? Não, pois quem gera valor é o capital produtivo. Sim, artificialmente. Contudo, é um artificial que pode se tornar real. Ou seja, parece que o capital fictício cria valor, pois impulsiona um aumento do capital produtivo. Se o capital fictício criou um valor fictício, artificial, que depois foi corroborado pelo capital produtivo com a criação de um valor real (mercadorias), quem criou este valor? Parece que não foi a produção, porque somente teria efetivado, isto é, tornado real algo que já existia, ainda que artificialmente. $\mathrm{O}$ trabalho criou valor na produção, mas este trabalho foi para criar um "valor já criado" artificialmente antes dele. Neste caso o trabalho operou uma transformação de algo fictício em algo real, e é a essa transformação que se deu o nome de geração de valor.

Assim sendo, parece que a produção se tornou um meio para se atingir uma finalidade posta pelo capital fictício. Ou seja, não foi o capital fictício que respondeu a uma determinação da produção, senão o contrário: foi o capital fictício que impôs uma valorização a ser cumprida posteriormente pela produção. A produção, como vemos, ocorreu para corroborar os anseios da valorização fictícia. O fictício parece comandar o real. Se isto não ocorrer, se o capital real não efetivar o que já foi criado artificialmente, uma crise irromperá.

Portanto, valor não é somente trabalho social abstrato cristalizado. Perguntemos: o valor fictício é valor? Com o que deveríamos responder: não como trabalho abstrato cristalizado, pois não foi de fato cristalizado. Porém, é um valor fictício que engendra um valor real. O capital fictício pode efetivamente comprar máquinas e trabalho e coloca-los em marcha no processo produtivo. Desse modo, o valor fictício é um vir-aser-valor, um devir. O que nos leva a concluir que o juízo "valor fictício é valor" é uma juízo de devir. Lembrando que é Hegel quem nos alerta para o fato de que "a Coisa mesma não se esgota em seu fim, mas em sua atualização; nem o resultado é o todo efetivo, mas sim o resultado junto com o seu vir-a-ser" (Hegel 2002, §3, p.26-27 ênfase nossa)

O valor fictício opera, como vemos, uma inter-versão. Se originalmente ele emergiu do valor, do capital real, agora ele, enquanto forma constituída, produz (no sentido de engendrar) valor. A criatura se torna criadora. $O$ valor fictício emerge do valor real 
para depois comandá-lo. Assim como faz o dinheiro com a moeda, que dela emergiu para torná-la um meio, enquanto o dinheiro mesmo se põe como fim, o valor fictício realiza o mesmo movimento: emerge do valor, faz dele seu meio e depois se coloca como fim. A produção real tem, pois, que "correr atrás" para efetivar o que o fictício já pôs em marcha. $O$ valor fictício, como devir do valor, se coloca como fim e faz de seu criador (o valor) um meio. O conteúdo, a finalidade, do processo já foi posta pelo valor fictício, cabe então encontrar os meios reais de efetivá-lo. É aqui, portanto, que fica mais claro o que Marx queria dizer com o capital enquanto um fim em si mesmo, como a produção pela produção.

Será, então, o valor somente valor como trabalho exigido para a reprodução, que "olha" para as condições presentes? Não haveria algo de fictício no valor ${ }^{135}$, que faça com que o valor "olhe para frente", no sentido de que o valor seja também trabalho ainda não incorporado?

Alguns autores, no entanto, não concebem nossa idéia como válida. Hilferding não capta que a mudança na forma tenha implicações sobre o conteúdo: "Speculation ... does not affect the capitalist enterprise [...]. An established enterprise is not affected by a change of ownership or by the constant circulation of shares. [...] The purchase and sale of these claims to interest is a purely economics phenomenon, a mere fluctuation in the distribution of private property, without any influence upon production or upon the realization of profit [...]. Speculative gains or losses arise only from variations in the current valuations of claims to interest" (1981, p.135). Ou seja, o capital fictício não influencia o capital real. Carchedi, infelizmente, vai na mesma linha de Hilferding e assevera que "[c]ontrary to the opinion of many authors (including Marxist authors), the crash does not destroy real capital, it does not destroy real wealth. It only destroys titles of ownership on that wealth" (1991, p.209). Para ele, quando o preço da ação cai a zero, há uma transferência de renda do investidor em favor da empresa, sem contrapartida na produção de mercadorias. Achar que a queda no preço da ação representa diminuição de capital real é o mesmo que achar que a diminuição do capital fictício representa uma respectiva diminuição do capital real: "Stock exchange crashes are not violent destructions of wealth; they are violent redistributions of wealth" (idem). Ou seja,

135 "Marx implicitly counted fictitious values as part of the values of capital" (Perelman 1990, p.87). 
Carchedi esposa a teoria de Hilferding de que a esfera da distribuição não impacta sobre a esfera da produção de valores. Para ambos, o capital fictício concerne à distribuição da riqueza, e não à produção dela; neste caso, o capital fictício é inadequadamente restrito a uma análise em que os mecanismos fictícios são mecanismos de controle sobre a renda já gerada. Mas de acordo com o que mostramos acima, tudo indica que temos exatamente o contrário: se o capital fictício for apreendido não no seu resultado mas em seu devir, aí perceberemos que o fictício é tanto fruto do real quanto seu produtor. Se o dinheiro é a forma que permite ao valor se libertar dos limites impostos pelas mercadorias, o capital fictício e a forma que permite ao capital libertar-se dos limites do ciclo industrial, do capital industrial (entendido como aquele que aparece no Volume II de $O$ Capital, cujas formas particulares são o capital-dinheiro, o capitalmercadoria e capital produtivo).

A afirmativa típica dos pós-keynesianos de que não são os empréstimos derivados dos depósitos, senão o contrário, que são os empréstimos que criam os depósitos que os justificam a posteriori, nos parece apropriada como evidência de que o capital financeiro, para se afirmar e se reproduzir, tem de se fazer capital fictício, para então posteriormente retornar como capital-portador-de-juros. Ou seja, a tese de que os depósitos são resultado, e não pré-condição, dos empréstimos, nos fornece uma primeira noção de como o capital financeiro é resultado, e não pré-condição, do capita fictício. Se origem lógica do capital fictício, como nos indica Marx, advém do capital financeiro, sua posição objetiva cria uma inter-versão ao tornar sua condição de existência seu próprio resultado. Agora, trata-se mais precisamente de dizer que é o capital fictício que produz capital financeiro, e não mais o contrário. Se é o crédito que cria o depósito, e não o contrário, isto implica dizer, neste caso, que é a forma que cria o seu suporte. Contudo, vimos que isto aparece como o caso de uma forma que deriva do seu suporte, do capital fictício que deriva do capital financeiro.

A continuidade do processo gera uma inter-versão, uma inversão que vem de dentro do processo mesmo, assim como ocorre na Seção VII do Livro I de O Capital, quando a análise da reprodução do capital, isto é, a análise da continuidade do movimento, evidencia que aí o capital como essência passa a efetivamente negar sua aparência e que seus pressupostos são repostos por seus resultados - assim como nos alertou acertadamente Fausto (1987a e 1987b). Aqui parece ocorrer o mesmo: a análise da 
continuidade do movimento do capital fictício revela que ele repõe o que pressupõe, recria seus pressupostos, reproduz suas pré-condições. É por isso que insistimos: o capital fictício realiza em sua dinâmica uma inter-versão. A primeira evidência disto jazia em nossa análise anterior do empréstimo que cria depósitos e a posição efetiva do sistema financeiro como um não-intermediário.

\subsubsection{Capital Financeiro e Capital Monetário como Predicados do Capital Fictício}

Poderíamos dizer que o capital fictício nunca aparece enquanto tal, senão através do capital financeiro (capital-portador-de-juros) ou do capital monetário (capitaldinheiro $)^{136}$. Isto é, o capital fictício está no nível da essência; sua aparência necessária, o capital financeiro ou o capital monetário, nega-o para conservá-lo. Assim, se o capital fictício emerge logicamente do capital financeiro ou do capital monetário, ele os mantém como seus predicados e como suas formas fenomênicas. "Capital-portador-de-juros" e "capital-dinheiro" são os dois predicados, momentos lógicos de aparição, do "sujeito" capital fictício - "sujeito" entre aspas porque este sujeito é sujeito fictício, já que só o capital é o verdadeiro sujeito. O capital é um movimento-sujeito, valor que se valoriza, enquanto que capital fictício é valor, mas que não consegue se valorizar, ainda que aparente isso. Ainda assim, há uma semelhança importante entre os dois: ambos, em seus movimentos contínuos, internalizam suas pressuposições, isto é, produzem suas próprias pré-condições.

Marx e Hilferding não asseveram isso explicitamente, mas podemos ver que esta idéia já está presente potencialmente: "conversion of profit-bearing capital into interest-(or dividend) bearing capital (Hilferding 1981, p.111-112); “[...] which enables the money capital to become fictitious capital at the same time to retain for its owners the form of money capital" (idem, p.113); "Transformação ... dos proprietários de capital em meros proprietários, simples capitalistas monetários” (Marx 1984a, p.332); o dividendo "passa

\footnotetext{
${ }^{136}$ A diferença entre as formas dinheiro e capital-dinheiro (capital monetário) é que na primeira o capital está pressuposto, enquanto que na segunda o capital está posto: "a fórmula do ciclo do capital-dinheiro ... tem por pressuposto a existência da classe assalariada em escala social" (Marx 2000, p.47). Lembrando também que o capital monetário aparece sempre como pressuposto do capital, nunca como resultado dele; ainda que em essência seja tanto capital adiantado quanto produto dele (idem, p.59)
} 
a ser recebido somente na forma de juro, isto é, como mera recompensa à propriedade do capital" (idem), assim, "o lucro assume aqui puramente a forma de juro" (idem). Harvey também resvala implicitamente em nossa hipótese ao dizer que "markets for fictitious capital are vital to the survival of capitalism, because it is only through them that the continuity of flow of interest-bearing capital can be assured" (2007, p.278). Passagens estas que indicam que o capital fictício opera por meio das formas capital monetário e capital financeiro.

\subsubsection{O Capital Fictício: A Mercadoria-Capital e o Seu Ciclo M-M’}

A nossa idéia a ser aqui defendida é a de que se o capital-portador-de-juros é mercadoria-dinheiro, dinheiro que se fez mediador e mediado de si mesmo (Paulani 1991). Podemos então afirmar que o capital fictício é mercadoria-capital, capital que se fez mercadoria para relacionar-se consigo mesmo por meio de um outro, mas um outro que também é ele mesmo e que ele mesmo produziu. "[Financial] wealth assumes the aspect ... of thing, matter, commodity, alongside of and external to the real elements of social wealth" (Marx apud Perelman 1990, p.82). O preço desta mercadoria-capital aparece nas cotações nas Bolsas de Valores e Futuros e nos mecanismos privados over-the-counter. O capital é aqui tratado como mercadoria, é negociado como mercadoria e o seu mercado é o "mercado de capitais". Isto é, capital fictício é "capital" que é comprado e vendido e que, assim, tem um preço. Capital fictício é capital como mediado e como mediador ao mesmo tempo, por isso é relação consigo mesmo. Assim entendido, o "mercado de capitais" é o espaço social onde o capital fictício é precificado:

"O movimento autônomo do valor desses títulos de propriedade, não apenas dos títulos da dívida pública, mas também das ações, confirma a aparência, como se eles constituíssem capital real ao lado do capital ou do direito ao qual possivelmente dêem título. É que se tornam mercadorias cujo preço tem um movimento e uma fixação peculiares" (Marx 1985b, p11 - ênfase nossa). 
Mais claro que isso é impossível: capital fictício é "capital” que se torna mercadoria, mercadoria-capital, mercadoria-“capital”, cujo preço é determinado de forma peculiar. Seu preço é peculiar porque esta mercadoria é peculiar. O capital não tem preço; quem o tem é a mercadoria-capital.

O capital fictício não pode ser sujeito de fato, pois sujeito é o capital, mas aqui o capital fictício é "sujeito", pois é exatamente "capital" (onde as aspas indicam justamente isso); é vir-a-ser sujeito, porém que nunca chega a esta determinação. Capital fictício é um eterno e contínuo devir de um sujeito que nunca se realiza. E, caso ele se "esqueça" disto, a crise vem lembrá-lo. A crise, contudo, opera uma inversão em relação à prosperidade: o que é real aparece como fictício e o que é fictício aparece como real. Nos períodos prósperos o capital bancário e o capital industrial são vistos como "sólidos" e a dívida estatal se mostra como um problema de gerenciamento do governo. Ao contrário, nas crises, temos que o capital bancário e o capital industrial se mostram como capital fictício, como algo não "sólido" ou não "fundamentado", e a dívida estatal se mostra como a solução (anti-cíclica) sólida, ainda que seja capital fictício par excellence.

$\mathrm{Na}$ forma de capital fictício temos o retorno do capital, do sujeito, ao seu predicado lógico inicial: é o sujeito que reaparece como Dasein, como ser-aí. Portanto, o capital fictício, mercadoria-capital, é a melhor determinação para o capital, pois pode incluir no seu predicado mais imediato (a mercadoria) todo o seu desenvolvimento lógico, assim como o faz o Absoluto de Hegel. É com esta chave de leitura que vamos entender a proposta de que "a simple but effective way of establishing a coherent perspective on globalization is buy building on Marx's insights into capitalism as a 'commodity system"” (Lysandrou 2005, p.774).

Hilferding em momento algum defende esta idéia, mas parece já deixar o espaço aberto para tal interpretação: "Fictitious capital, a certificate of indebtedness, is a commodity sui generis which can only be reconverted into money by being sold" (1982, p.128 - ênfase nossa). Vemos, portanto, que ele denomina o capital fictício de mercadoria sui generis. E, para nós, se trata justamente disto. O capital enquanto capital fictício é capital que se faz mercadoria, mas não qualquer mercadoria, senão uma mercadoria especial, sui generis. E tem este estatuto privilegiado pois é 
o capital em seu maior grau de desenvolvimento que volta ao Dasein, ao ser-aí. Ou seja, é uma existência que conforma todo o percurso lógico produzido pelo sujeito capital; é o predicado mais simples, mas que guarda dentro de si todo o movimento do sujeito. Aproxima-se, pois, do Dasein hegeliano que, além de ponto de partida, é ponto de chegada do espírito ao refazer seu próprio percurso como Absoluto. É o espírito que se fez coisa. É o capital que se fez mercadoria. Talvez seja esta relação do capital consigo mesmo, em uma espécie de mecanismo auto-referente, que permite a Rotman afirmar que um derivativo "creates its own significance: one which is written in the only terms available to it, namely future states of itself. [...] it is a sign which creates itself out of the future" (1987, p.94-95).

Segundo Carchedi (1991, p.207), a ilusão de que títulos de propriedade sobre capital são capital (como as ações) deriva do fato de que estes títulos tornam-se "mercadoria", já que são comprados e vendidos na Bolsa. Ou seja, a ilusão objetiva do capital fictício, como algo artificial que se apresenta como real, deriva exatamente do fato do capital se pôr aí como mercadoria, como algo que é tomado como o mais "sólido" e "estável" pelo sistema. O capital fictício se manifesta como mercadoria porque aí a mercadoria exerce o papel do "não-fictício". O artificial não pode aparecer como o que é; para ser o que é precisa se exibir como o que não é.

Uma das teses de Paulani (1991) é a de que o dinheiro carrega consigo um pouco da dimensão do infinito hegeliano, que é o que determina o sujeito - o que não ao ocorreria com o outro momento do capital, a mercadoria ${ }^{137}$. Sem dúvida, Marx quer mostrar isso quando diz que o ciclo da mercadoria M-D-M tem sua finalidade externa enquanto que o ciclo do dinheiro D-M-D internaliza sua finalidade, e daí seu "algo de infinito". Entretanto, como aqui almejamos mostrar, o capital fictício, que é mercadoriacapital, capital que se fez ele mesmo mercadoria, evidencia que o ciclo da mercadoria também pode conter algo de infinito, justamente porque é ciclo da mercadoria-capital. Neste sentido, é verdade que o dinheiro é o predicado mais próximo do sujeito capital, mas a mercadoria - quando analisada enquanto posição do capital fictício - também se aproxima muito de seu sujeito. Ou seja, o capital fictício vem a dar mais “dignidade” à mercadoria enquanto predicado lógico do capital.

${ }^{137}$ O dinheiro é o "predicado mais importante e mais íntimo do capital", afinal "é a figura que assume para si o papel de sujeito agindo como se sujeito de fato fosse" (Paulani 1991, p.157). 
Neste sentido, o ciclo mais aparente e mais superficial do capitalismo, justamente aquele que fornece o semblante necessário de sociedade mercantil assentada na troca de equivalente, é agora o ciclo do capital fictício, da mercadoria-capital. Ou seja, o circuito M-D-M que outrora possuída sua finalidade no exterior, fora dele, pode agora internalizar seu motor, tornando-se movimento infinito. $O M$ de mercadoria é aí mercadoria sui generis, mercadoria-capital, que encarna todos os estágios anteriores do capital em si mesma. Ou seja, se na Seção I do Volume I de $O$ Capital o circuito M-D-M é movimento finito, na Seção V do Volume III ele torna-se infinito, pois internaliza sua finalidade ao ver o sujeito capital retornar enquanto sujeito a seu próprio predicado de mercadoria. O circuito M-D-M' mostra que a mercadoria passou de meio a finalidade.

Não obstante, isto ainda vai além. O ciclo M-D-M é o ciclo da mercadoria, onde o dinheiro figura como moeda, medida dos valores e meio-de-circulação. Mas no ciclo MD-M da mercadoria-capital o movimento aparece como simplesmente M-M, ou melhor, M-M', o ciclo do capital fictício. É a mercadoria que parece valorizar-se por si só via variações de preço - o que, como veremos, é característico do mercado de derivativos financeiros. O que não se confunde com o ciclo do capital financeiro, capital-portador-de-juros, que é D-D', dinheiro que parece gerar mais-dinheiro por si só. No caso do capital financeiro, o D-D' existe por que um agente paga juros para o dono do dinheiro. No caso do capital fictício, o M-M' não decorre de um pagamento de juros, mas decorre sim de uma variação no preço da mercadoria-capital - que é precisamente uma variação no preço de um contrato ou de uma security. Lysandrou está longe de dizer o que aqui afirmamos, mas de certa forma enxerga um processo no qual a forma mercadoria ganha proeminência: "The fact that the shares and bonds of bank corporations represent marketable claims on the profits made from their deposit-taking and lending activities effectively implies that the underlying lending-borrowing relation has itself become commodified" (2005, p.776).

Se o fetiche do capital financeiro é apresentar o seu ciclo D-D-M...P....M'-D'-D' simplesmente como D-D', aqui dizemos que o fetiche do capital fictício é apresentar seu ciclo M-D-M...P....M'-D'-M' (onde o M inicial e o M' final são a mercadoriacapital, que é um contrato de derivativo ou uma security) simplesmente como M-M', 
apagando qualquer rastro da real criação de valor. O que se vê são somente ganhos e perdas em função de variações nos preços de contratos sobre ativos.

Com a mercadoria-dinheiro o dinheiro, que é meio, aparece como mediado. Com a mercadoria-capital o capital, que é sujeito, aparece como objeto; é sujeito que se faz objeto e se relaciona consigo mesmo por meio de um outro que é sua própria exteriorização. É sujeito que se fez objeto, mas que enquanto objeto nega conservando seu estatuto de sujeito. Como capital fictício, o capital é objeto que suprime o sujeito. Portanto, capital fictício é um movimento infinito, capital que se relaciona com capital, consigo mesmo, por meio de um outro, de um outro-objeto, que é e não-é ele mesmo ${ }^{138}$.

\subsection{O Mercado de “Capitais” Após 1971}

\subsubsection{O Mercado de Capitais como Aparência}

Como inicialmente nos lembrou Hilferding (1981, p.131), a definição de Bolsa de Valores como um "mercado de capitais" nos faz perder a natureza essencial desta instituição, que é um mercado de securities (todo tipo de certificado que representa uma soma de dinheiro $)^{139}$. As securities são direitos sobre direitos de apropriação de parte do lucro. São, portanto, direitos de propriedade de ordem superior, transacionáveis e retransacionáveis. E, atentemos: é esta capacidade infinita de revenda delas que aponta para um desdobramento do princípio da mercadoria (Lysandrou 2005, p.776).

A denominação de "mercado de capitais" é deveras inadequada para expressar o que de fato ocorre na Bolsa. Não são os capitais que são negociados, senão certificados sobre

\footnotetext{
${ }^{138}$ Em verdade, deveríamos usar a notação de mercadoria-“capital” para o capital fictício, já que não se trata de um sujeito efetivo, senão de um "sujeito", sujeito fictício. Este "capital" entre aspas indica que se trata de um capital é que aparentemente capital mas que essencialmente não o é.

${ }^{139} \mathrm{O}$ fato de o mercado de capital fictício ser o mercado das securities tem impactos significativos sobre a moderna técnica de contabilidade destes títulos. As várias formas de contabilidade acompanharam os diferentes modos de organização corporativa e, com a maior dinâmica financeira a partir da década de 1990, a prática contábil está deixando a consolidada abordagem "receitas-depesas" em função de uma nova abordagem "ativo-obrigações" (assets-liabilities) (Jinnai 2005, p.104). Ademais, "the primary function of recent reformation of capitalist accounting is to reactivate non-active capitalists, especially securities dealing capitals. [...] What is particular to the present mode of economy is the relationship between accounting standard setting and the security markets, or, those who represent the interests of the security markets in general or the particular type of capitals: securities dealing capitals" (idem, p.110 - ênfase nossa).
} 
somas de dinheiro. O dinheiro aí pode representar ou não um capital real e, se representa, é somente através de várias camadas de mediação.

Partindo destas asserções iniciais, e adotando uma perspectiva dialética, diríamos que o título de "mercado de capitais" é adequado e inadequado. É inadequado porque essencialmente esse mercado é um mercado não de capital, mas de capital

fictício. É adequado porque inverte a essência e apresenta como capital algo que não o é - o que é justamente próprio ao movimento do capital fictício. O mercado de capitais apresenta como capital o que não é capital. Dessa forma, o "mercado de capitais" é o mercado por excelência do capital fictício, um movimento do capital que é essencialmente não-capital e aparentemente capital, sendo que a denominação "mercado de capitais" não é nem de longe fortuita, já que expressa dialeticamente o que o capital fictício é.

Como ficará mais claro nos próximos itens, uma de nossas asserções é a de que o mercado de capitais realiza uma redução, uma abstração objetiva, em que os diferentes "capitais" - onde as aspas indicam que se trata de um capital fictício - são paulatinamente homogeneizados. Assim sendo, estes distintos e particulares "capitais" são reduzidos a suporte de transações que objetivamente abstraem de suas particularidades, colapsando toda a concretude em um preço cotado pelos mercados financeiros. Portanto, o capital fictício, ao mostrar-se como força universalizante, porque objetivamente homogeneizante, tentará reduzir seu real sujeito a suporte.

Cabe aqui ainda uma última palavra. Marx diz que o valor de uma mercadoria é determinada pelo tempo socialmente necessário para sua reprodução, isto é, que o valor de uma mercadoria varia conforme as condições atuais de tecnologia. Se pensarmos no capital fixo, que é uma mercadoria que sobrevive por vários ciclos, veremos que o seu valor oscilará muito de acordo com as alterações nas condições de sua reprodução. Portanto, os valores já produzidos no passado devem ser continuamente reavaliados pelo crivo do mercado e "to some degree, the variation in stock can be prices viewed as a reflection of the shifting values of the stock of fixed capital itself" (Harvey 2007, p.268). Isto é, as oscilações de preços do mercado de capitais refletem em parte o fato de que os valores, apesar de já produzidos, são constantemente recalculados de acordo 
com as condições do mercado. Neste caso, os preços flutuam porque os valores flutuam, já que o que determina o valor não é o tempo de produção, mas sim o de reprodução.

\subsubsection{O Dinheiro Inconversível e o Capital Fictício Próprio a Ele}

O fim dos acordos de Bretton Woods durante o governo de Nixon nos EUA em 1971 e as subseqüentes desregulamentações financeiras, nutriram uma nova dinâmica financeira mundial que ainda está longe de ser devidamente entendida. Nossa proposta aqui é dar um passo adiante neste tema através das categorias marxistas, sejam elas como se encontram nos escritos originais ou sejam elas introduzidas por nós afim de melhor apreendermos esta hodierna dinâmica.

A década de 1970 marca, portanto, o estabelecimento definitivo do dinheiro inconversível como paradigma monetário internacional, sendo daí derivados, posteriormente, os regimes cambiais mais livres e a maior liberdade às flutuações das taxas de juros domésticas. Estes dois elementos representam para o presente trabalho os ingredientes cruciais para a formação do capital fictício próprio a eles no pós-1971, ano que marca a desvalorização unilateral do dólar. De Marx tomaremos a categoria de “capital fictício" para a modificarmos conforme nosso objeto de estudo assim o exija.

A questão central é que os acordos de Bretton Woods exerciam um papel crucial na estabilidade do sistema monetário e financeiro através da forte regulamentação sobre os movimentos de capitais, câmbio e juros e, inexoravelmente, através da formação das expectativas dos agentes. Quando tais acordos foram descontinuados os agentes se viram desprovidos do que mais lhes servia como balizador de expectativas, pois eram as autoridades monetárias que internalizavam as funções de hedging dos agentes. Qual a solução então? Como o mecanismo público não mais operava, a resposta foi a criação de mecanismos privados que tentassem balizar a formação das expectativas em meio a um evidente ganho de volatilidade nas variáveis-chave da economia: câmbio e juros. Este é o cenário para o surgimento inevitável dos derivativos, "instrumentos" que visavam preencher o vazio deixado pelo fim das regulações estatais pré-Nixon. Ou, como diz Harvey, "[m]arkets for fictitious capital provide ways to co-ordinate the coordinating force in capitalist society" (2007, p.278). 
Ou seja, temos que apreender o dinheiro inconversível como dinheiro mundial sob, no mínimo, dois aspectos: (a) a instabilidade cambial e de juros que o dinheiro inconversível produz enquanto dinheiro mundial; (b) a formação dos mercados de derivativos sobre as taxas cambiais e sobre as taxas de juros, e sua importância para a produção de capital fictício. "Financial derivatives are essentially wagers on changes in the price of money (i.e. interest rates) or relationships among national currencies" (LiPuma e Lee 2005, p.407). Em suma, os derivativos devem ser compreendidos como um mecanismo moderno que atrela o futuro ao presente, preenchendo o espaço deixado pela retirada do aparato estatal desta função. Além do mais, variações cambiais e nas taxas de juros podem influir muito sobre os preços dos ativos (como títulos de dívida e ações), já que expectativas sobre o comportamento destas variáveis induzem os fundos a trocar de securities demandadas em diferentes divisas, e/ou porque tais variações influem diretamente nos próprios preços das securities. Portanto, o fim das regulamentações típicas do pré-1970 e o conseqüente aumento desta volatilidade mencionada acabou por aproximar dois mercados antes afastados, o mercado de dinheiro e o mercado das Bolsas de Valores.

Seguindo esta linha, veremos que o mercado de derivativos é a ligação lógica necessária entre a introdução do dinheiro inconversível e a formação de capital fictício própria a ele. Não se trata, pois, de uma contingência histórica. Se em nosso capítulo 3 mostramos que há uma necessidade forte para o aparecimento da forma inconversível do dinheiro, agora vemos que no mundo dos negócios não há decisões de investimento sem mecanismos que atrelem o futuro ao presente. Os derivativos resolvem privadamente o problema de como investir em um ambiente em que o dinheiro mundial é uma pura forma. Portanto, há uma derivação em sentido forte que vai do dinheiro inconversível aos derivativos como espaço social de formação de capital fictício $^{140}$.

Nossa empreitada teórica é mostrar que esses novos “instrumentos” financeiros são também objetos contraditórios, pois são singulares, universais-concretos, que

\footnotetext{
${ }^{140}$ Vale notar que os títulos públicos dos EUA tornaram-se, após os anos 1980, a referência mundial para a precificação de todas as outras securities de acordo com um ranqueamento de risco, sendo esse mecanismo o que substituiu o sistema financeiro pré-1970
} 
aparecem como "proteção" (hedge) contra as oscilações inerentes aos mercados, ou que aparecem ainda como simples caso de "gerenciamento de riscos". E, como já afirmamos acima, os derivativos se adéquam à categoria de capital fictício exatamente porque se apresentam como capital - daí a denominação de "mercado de capitais" -, mas que essencialmente não representam capital algum.

O mundo do século XIX que Marx tinha como base de seus estudos era um mundo no qual o capital fictício era representado pela transação de títulos de propriedade sobre rendimentos, como títulos de dívida, ações e rendimentos capitalizados pela taxa de juros. O que de fato não é o mundo financeiro do pós-1971, que passou a contar com mecanismos bem mais complexos de formação de capital fictício, como os derivativos, que são contratos firmados sobre ativos subjacentes que eles mesmos não controlam mas cujos rendimentos deles derivam, e as securitizações, principalmente as de dívidas. Se os títulos por si só já são autonomizações em relação ao "capital” que supostamente deveriam representar, os derivativos e as securities de dívida sem dúvida alguma são um passo maior em direção à autonomia entre rendimento e mais-valia ${ }^{141}$.

Com o padrão-ouro a manutenção da convertibilidade da moeda em metal era realizada às custas de grandes variações no produto doméstico. Após a Segunda Guerra Mundial observa-se uma maior estabilidade do produto, principalmente quando comparado ao seu comportamento durante o século XIX. Em grande medida, tal estabilidade foi fruto das "repressões" ao sistema financeiro internacional e das limitações aos movimentos de capitais. Contudo, com o fim dos acordos, com o fim do câmbio fixo e com o fim das regulamentações financeiras, a estabilidade do nível do produto e do nível de preços passa a ter um novo custo social que somente pode ser entendido a partir da forma dinheiro inconversível, qual seja: a maior instabilidade dos juros e do câmbio. E, para os derivativos financeiros, é essa dupla volatilidade sua razão de ser. O dólar, a despeito de ser moeda mundial, não consegue exercer o papel estabilizador que o padrão-ouro

141 Uma das teses de Chesnais (2005, p.48-49) é a de que os detentores das ações e de volumes importantes de títulos de dívida pública devem ser redefinidos como proprietários situados em oposição exterior à produção, e não como credores. É, portanto, um regime de "acumulação patrimonial” - como já afirmava Aglietta (1999). Sendo que este "patrimonial" diz respeito à determinação que o termo "credor" não suporta. O "patrimônio" designa uma propriedade (mobiliária e imobiliária) que foi acumulada e dirigida para o rendimento. $\mathrm{O}$ termo "credor", por sua vez, remete ao empréstimo bancário e ao crédito, capital-portador-de-juros, e trata-se de um financiamento efetivo. O capitalismo patrimonial vai além, pois concerne ao mercado secundário de títulos, que negocia somente ativos já emitidos. 
exercia e nem opera com uma unidade estável de mensuração como o fazia a matéria metálica $^{142}$.

Por fim, se o dinheiro é inconversível, o Banco Central pode expandir a oferta monetária para defender a economia contra uma sobre-acumulação e conseqüente desvalorização das mercadorias. Mas ao fazer isso o BC desvaloriza a moeda nacional. Desse modo, a tendência à sobre-acumulação é convertida em uma tendência à escalada inflacionária. Defender o valor nominal das mercadorias que incorporam trabalho socialmente desnecessário é tão irracional quanto defender o dinheiro como pura medida dos valores através de um padrão-ouro clássico. Inflação é tão ruim para a economia quanto a desvalorização das mercadorias. Portanto, a contradição entre o sistema financeiro e sua base monetária é uma expressão da contradição entre o capital como dinheiro e o capital como mercadoria (Harvey 2007, p.296). Sob condições de sobre-acumulação, o BC parece ter uma escolha entre desvalorizar o dinheiro via aumento da inflação ou desvalorizar as mercadorias via queda no produto. Ao tentar evitar ambos, o BC incorre nos dois.

\subsubsection{Dinheiro Inconversível e Taxas Cambiais}

Quando Marx fala das taxas cambiais, ele se mostra ainda preso ao dinheiro metálico como dinheiro universal. Se juntarmos o fato dele ter afirmado que no que concernia ao mercado mundial o ouro em matéria deveria se fazer presente e que, portanto, as taxas cambiais entre os países são resultados das transações de ouro - assim como fica explícito no Item 2 do Capítulo 35 do Volume III de $O$ Capital -, perceberemos que ele não investigou os impactos da formação de capital fictício sobre a determinação das taxas cambiais. Afinal, "Marx's discussion of inconvertibility is set in the context of simple commodity production in the early part of Capital I, not capitalist production in

\footnotetext{
${ }^{142}$ No caso dos derivativos cujo ativo subjacente seja uma moeda nacional, o objetivo dos agentes é superar a falta de confiança sobre o valor da moeda estatal - o que serve de forte argumento contra as teses estatais ou sociais do dinheiro, assim como atualmente propostas por Geoffrey Ingham e Randall Wray. A convertibilidade de um derivativo financeiro depende não da confiança sobre o poder estatal de manter a unidade de conta, senão justamente o contrário, já que existência dele decorre da própria falta de confiança sobre a estabilidade da unidade de conta, e depende muito mais da confiança sobre outros agentes privados. É aqui que medidas como rating de crédito, margin calls e swaps de default de crédito são privadamente elaborados para dar suporte financeiro às reputações. Isto é, as garantias são privadas, e não estatais (Bryan e Rafferty 2007, p.147-149).
} 
Capital III" (Likitkijsomboon 2005, p.163). Ao que tudo parece indicar, quando se tratava de taxas cambiais, ele se restringia ainda ao dinheiro com sua forma metálica. $\mathbf{O}$ conceito de capital fictício parece, portanto, ter ficado restrito ao âmbito doméstico. Trata-se agora de internacionalizar sua categoria.

Quando prevalecia o regime do padrão-ouro pleno (1870-1914), a determinação teórica das taxas cambiais de equilíbrio não representava um sério problema. Entretanto, com a Primeira Guerra Mundial o padrão fora inevitavelmente suspenso - aliás, em períodos de guerra, quando os gastos dos governos são potenciados, a conversibilidade sempre foi suspensa -, o que colocava uma pergunta teórica importante: quando o dinheiro é inconversível, o que determina a taxa cambial de equilíbrio?

O primeiro economista a sugerir uma resposta, que até hoje é usada, foi Gustav Cassel (1918) com um artigo de três páginas. Perguntava ele como o câmbio de equilíbrio é formado em relação à "economia real”. Resgatando o raciocínio de Jevons de 1875 sobre os tabular standards - para o qual cada moeda tinha um poder de compra definido na esfera doméstica e calculável por estatísticas sobre os preços dos bens Cassel retoma a idéia de definir um câmbio de equilíbrio em função do poder de compra doméstico das moedas nacionais sobre bens idênticos e livremente acessíveis. Como sabemos, Cassel propôs a criação de um índice PPP (purchase power parity), para o qual o câmbio de equilíbrio deveria zerar todas as diferenças de preços internacionais sobre bens homogêneos. A questão não é discutir aqui a validade ou não de uma "lei do preço único", mas sim em pôr o problema de saber o que determina um câmbio de equilíbrio - questão esta que está inegavelmente interligada com o desafio de saber como o dinheiro inconversível opera como medida dos valores. Isto é, a expressão internacional do problema teórico de sabermos o que determina o valor do dinheiro domesticamente é a questão de sabermos o que determina a taxa cambial de equilíbrio.

Ademais, ainda que o sistema assentado sobre o dinheiro inconversível implique em padrões monetários e taxas cambiais instáveis, a ilusão de um padrão monetário estável persiste. O sistema precisa produzir esta aparência: "These means are not found like a buried treasure. They must be produced. Those measures that counter uncertainty (i.e. derivatives) can therefore be seen as 'productive' insofar as, by their calibrations, they 
'permit' the conceptual presumption of a stable monetary standard" (Bryan e Rafferty 2007, p.149). Ou, como diz Brunhoff (2005b), o uso moderno da teoria de Cassel do PPP apaga a idéia da hierarquia mundial de moedas, pois aí o dinheiro funciona como um dinheiro homogêneo enquanto unidade de conta.

O derivativo financeiro produz sua própria aparência, que nega o que na essência ele põe. Se sua razão de ser é justamente a instabilidade do padrão monetário, mas concomitantemente cria a aparência de que reina aquilo que sua existência mesma nega, a estabilidade do valor do dinheiro.

\subsubsection{Dos Derivativos aos Derivativos Financeiros}

Os derivativos, entendidos em seu sentido amplo, existem desde o século XVIII, inicialmente sob a forma de contratos futuros entre produtores e comerciantes de mercadorias. O Chicago Board of Trade (CBOT) fora criado em 1848 a fim de trazer produtores e comerciantes mais próximos. Inicialmente a tarefa consistia em padronizar a quantidade e a qualidade dos grãos comercializados, mas logo evoluiu para contratos futuros. Assim, abriu-se a possibilidade de além de comercializar os grãos, comercializar adicionalmente os contratos de entrega dos grãos. Em 1919 é criado um novo mercado de futuros, o Chicago Mercantile Exchange (CME). Em tempos mais recentes o Chicago Board Options Exchange (CBOE) começou a operar com opções de compra. As opções, não obstante, já existiam antes disso, mas o CBOE em 1973 criou um mercado organizado com contratos bem definidos. E, em 1977, iniciaram com as opções de venda.

Nem todas as transações são feitas nas Bolsas (exchanges), sendo o mercado direto over-the-counter (OTC) uma importante alternativa - que, mensurado em volume total de transações, tornou-se bem maior do que o mercado das Bolsas de Valores e Futuros. A vantagem do mercado OTC é que ele goza de maior liberdade, pois não tem as especificações das Bolsas, ainda que tenha um risco de crédito mais elevado ${ }^{143}$.

\footnotetext{
${ }^{143}$ Segundo dados do BIS, apresentados em Hull (2006), em junho de 2004 o volume de trasanções via Bolsas era de 50 trilhões de dólares, enquanto que as de OTC já chegavam à marca de 220 trilhões de
} 
Não obstante, a dinâmica mundial dos últimos 30 anos implementou algo de inédito nestes mercados de contratos: a dominância dos derivativos financeiros sobre os derivativos de mercadorias. Enquanto os segundos estão presentes desde há muito, os primeiro são especificamente relacionados às finanças modernas da era pós-Nixon, sendo que já representam 98\% de todas as transações com derivativos (Hull 2006). Portanto, nossa análise se fixa sobre os derivativos financeiros, forma preponderante dos derivativos ${ }^{144}$; donde ainda destacamos que sua expansão se deu paralelamente à expansão da securitização de dívidas.

Com tais novos instrumentos, um agente pode controlar uma quantidade muito grande de um ativo sem de fato possuí-lo, pois somente uma pequena parte do contrato é "real". A quantidade efetivamente investida é ínfima perto do valor do contrato que ele comanda. Em outras palavras, os derivativos - e em especial os financeiros - controlam valores bem superiores aos valores de fato existentes e, por isso, assumem também a capacidade de determinar com muito mais influência as variáveis-chave da economia, como câmbio e juros ${ }^{145}$.

Os derivativos financeiros são em geral apreendidos como "políticas de seguro" ou como "instrumentos de gerenciamento de risco" (ou mesmo como "mecanismos de especulação"), sendo o seu caráter monetário ignorado pela ciência ${ }^{146}$. A questão aqui se torna, então, ultrapassar esta leitura superficial dos derivativos que os hipostasia através da "análise de risco", tematizando-os enquanto formas de mercadoria, dinheiro e capital.

dólares (5 vezes maior que o PNB mundial), dos quais somente 6,4 trilhões diziam respeito aos valores dos contratos.

${ }^{144}$ Para obtenção de dados recentes sobre o mercado de derivativo, ver www.occ.treas.gov . Para uma boa exposição dos tipos de derivativos financeiros (opções, futuros, forwards, swaps, derivativos de crédito etc.) e o seus respectivos funcionamentos e operacionalidades ver Hull (2006).

${ }^{145}$ Vale ressaltar também que a maioria dos contratos futuros não leva à entrega de fato do ativo subjacente, já que a maioria dos traders escolhe fechar suas posições antes da maturidade (Hull 2006, p.23). O fechamento da posição ocorre quanto o trader entra em uma transação oposta à original. "Delivery is so unusual that traders sometimes forget how the delivery process works" (idem). Entretanto, é justamente a possibilidade de uma eventual entrega que determina o seu preço (idem, p.35).

${ }^{146}$ Se seguirmos a teoria convencional, veremos que os derivativos são entendidos como um meio de gerenciar não somente riscos corporativos, mas também os riscos sociais e pessoais. Ver Shiller (2003) para ter em conta que o uso dos derivativos não tem limite que a imaginação não conceba, extrapolando todas as fronteiras do "campo econômico". Esta parece ser, a nosso ver, uma bela demonstração de como o capital é sujeito social que fornece o vetor valorativo que baliza todas as esferas sociais, opostamente a qualquer perspectiva weberiana de "desencantamento do mundo". Os derivativos são, assim, uma existência efetiva de algo (o capital) que tende a fornecer o valor unificador de todas as esferas autonomizadas da vida social. Sobre isto já tratamos no item 1.3 do capítulo 1 deste trabalho. 
Isto é, se sua aparência remete ao "gerenciamento de risco", sua essência - como tentaremos mostrar - concerne às determinações e às categorias que são ou predicados ou desenvolvimentos do capital.

O discurso dos derivativos enquanto instrumentos de gerenciamento de risco advém das teorias ortodoxas, como a teoria neoclássica, sobre as finanças. Segundo tal corrente, estes instrumentos envolvem uma questão de decisão sob condições de incerteza, na qual os futuros, fowards e opções são meios de se atingir posições ótimas em relação aos movimentos futuros dos preços dos ativos, assumindo ou se livrando dos riscos das variações de preços de maneira calculada. Os agentes, em face às incertezas, desejarão travar suas posições em algum preço futuro desejado (via forwards e futuros) ou desejarão adquirir um contrato que lhes forneça a possibilidade, mas não a obrigação, de vender ou comprar um ativo em datas e preços específicos no futuro (via opções). Sendo que o que os torna tão atraente ao gerenciamento de risco é o seu baixo custo, já que eles fornecem a exposição desejada sem que o seu contratante de fato possua qualquer um dos ativos dos quais esses riscos derivam. Os donos dos derivativos não são donos dos ativos subjacentes ${ }^{147}$.

Neste sentido, os derivativos são o risco tornado mercadoria: "derivatives are commodified risk" (Bryan e Rafferty 2007, p.126). Com eles se torna possível comprar e vender exposição aos movimentos de preços de um ativo sem ter que realmente possuí-lo. A teoria convencional, ao contrário disto, continua com o seu mesmo discurso de que se trata de um problema de eficiência alocativa, sendo os derivativos facilitadores de uma eficiência inter-temporal e inter-espacial - mas longe de qualquer

\footnotetext{
${ }^{147}$ Poder-se-ia dizer que se por um lado os derivativos vêm a cobrir os riscos das oscilações futuras de preços, por outro se poderia também dizer que a própria introdução desses mecanismos traz novos riscos, dados o seu baixo custo, o seu desgarramento em relação ao ativo subjacente e a possibilidade de ensejar posições com elevados graus de alavancagem, a despeito do fato de eles terem sido criados para minimizar os riscos. Contudo, aqui não nos preocuparemos com essa discussão sobre se os derivativos aumentam ou não a volatilidade dos mercados financeiros, se eles concentram poder de mercado de certos agentes ou se eles engendram problemas éticos. O nosso ponto precede: queremos compreender o que são os derivativos, isto é, qual é a sua essência e quais são suas determinações. A crítica de Bryan e Rafferty (2007, p.137-138) é aguda. Dizem eles, acertadamente, que os críticos da teoria neoclássica centram seus argumentos no fato de os derivativos acabarem por cumprir um papel oposto ao imaginado pelos seus adversários. Isto é, onde os neoclássicos enxergam eficiência alocativa, seus críticos enxergam especulação e concentração de poder. Entretanto, tais "críticos" vêem essencialmente o mesmo papel dos derivativos do que a teoria que criticam, ainda que com conclusões contrárias. Ainda que sejam críticos da teoria convencional, tomam dela a hipóstase da aparência, e daí não sobra espaço para as discussões sobre o caráter monetários dos derivativos. O campo de discussão "especulação versus hedging" não é esclarecedor quando o que se quer de fato é investigar o seu aspecto constitutivo.
} 
apreensão destes derivativos enquanto unidade de medida. A teoria neoclássica entende que o ponto em questão é como os agentes usam os derivativos estrategicamente para tornarem suas posições de risco uma escolha consciente e racional, ainda que os derivativos sejam instrumentos de transferência e não de eliminação do risco (Pryke e Allen 2000, p.268). Neste sentido, é a precificação do risco que assume papel central: a que preços estes contratos futuros e de opções devem ser transacionados? ${ }^{148}$ Com este problema formalmente resolvido, as alocações sob condições de incerteza serão eficientes ${ }^{149}$. E, em meio a tudo isso, o caráter monetário dos derivativos fica posto de lado.

Vimos que o "preço" da mercadoria-dinheiro, capital-portador-de-juros, aparece como o juro. No caso do derivativo, entretanto, o seu preço não aparece como juro. Nenhum manual de finanças chega a afirmar isso. Como veremos com mais detalhes à frente, o preço do derivativo é um preço de fato, preço de uma mercadoria especial, mercadoria-capital, capital fictício.

Ainda assim, vamos mais além. O que são os "ativos subjacentes aos derivativos"? São capital fictício, assim como diz o próprio Marx. Portanto, os derivativos financeiros são capital fictício que medeia capital fictício, isto é, capital fictício que medeia a si mesmo. $\mathrm{O}$ ganho advindo do contrato de derivativo financeiro advém de outro ativo que também já está autonomizado em relação à produção. Portanto, o derivativo financeiro é capital fictício como mediado e mediador concomitantemente. Agora a coisa vai mais além, pois ele é capital fictício montado sobre capital fictício, para o qual não há mais qualquer momento do capital real. Assim, enquanto derivativo financeiro, o capital é efetivamente capital fictício, mercadoria-capital sem qualquer vestígio de sua origem ontológica, pois aí não há mais qualquer "sombra" de capital que seja.

\footnotetext{
148 Isto nos faz lembrar que "o cálculo é a linguagem por excelência do entendimento" (Fausto 1997, p.100) e que a contabilidade é a linguagem do capital, como mostrou Weber na Introdução da Ética Protestante.

${ }^{149}$ A propósito, foi esta empreitada que rendeu aos autores do modelo Black-Scholes de precificação de opções o prêmio Nobel em economia de 1997.
} 


\subsubsection{Derivativos Financeiros como Mercadoria e a Produção do Risco Abstrato}

O mercado de derivativos, como desenvolvimento das formas do capital, não suprime as contradições já existentes, senão que produz novas formas dentro das quais elas podem mover-se. Os derivativos são a síntese de complexas relações sociais em um objeto reconhecível, o contrato, mas que nele se apagam, dado que aparece como independente destas relações sociais que o constituem. $\mathrm{O}$ derivativo aparece somente enquanto um simples contrato que permite aos agentes a possibilidade de hedge ou de especulação (LiPuma e Lee 2005 p.408). Os derivativos são usados e entendidos como instrumentos financeiros, porém ainda não está claro que tipo de objeto eles são.

Para Bryan e Rafferty (2007), o dinheiro assumiu novas funções em decorrência da criação dos derivativos financeiros, os quais seriam uma nova forma de moeda mundial. Segundo estes autores, os derivativos financeiros se aproximam do dinheiro por serem muito líquidos, mensurarem o "valor" dos ativos e por operarem como moeda de troca. Além disso, o BIS e o FMI os incluem em seus agregados monetários mundiais ${ }^{150}$. E, se assim entendermos os derivativos financeiros como dinheiro, então temos de considerar a oferta "extra" de dinheiro de 196 trilhões de dólares (segundo dados da ISDA para $2005)^{151}$. Volumes estes que tornam outras formas tradicionais de dinheiro quantitativamente insignificantes. Segundo estes autores, o papel central dos derivativos é servir de medida do valor para os vários ativos financeiros e físicos, incluindo-se aí o próprio dinheiro. Sendo justamente este o aspecto do derivativo que mais opera no mercado, muito mais do que sua função como meio-de-circulação. Os derivativos garantem que os ativos serão mensurados pelos mecanismos competitivos descentralizados, e não mais por mecanismos estatais de controle sobre a economia (como, por exemplo, o câmbio fixo). Pryke e Allen (2000) compartilham também da idéia de que os derivativos são uma nova forma de dinheiro, que monetiza novas combinações do espaço e do tempo, e que mudaram radicalmente como se gerencia o risco e como se entende o que é dinheiro e o que ele de fato pode realizar. LiPuma e Lee

\footnotetext{
${ }^{150}$ A questão de como os derivativos são computados permanece em aberto. Ver Vrolijk (1997) sobre a abordagem do FMI.

${ }^{151}$ Ver o relatório da International Swaps and Derivatives Association (ISDA) intitulado Summaries of Market Survey Results, disponível em: www.isda.org .
} 
(2005) também reconhecem o papel monetário dos derivativos financeiros, que ampliaram a oferta de crédito mundial, ainda que esses contratos não sirvam como reserva de valor ou como meio de troca.

As idéias propostas por Bryan e Rafferty (2007) são, no mínimo, muito interessantes e persuasivas, ainda mais quando mostram que o próprio FMI e o BIS entendem os derivativos como dinheiro. Entretanto, os derivativos têm uma característica que dificulta sua apreensão enquanto dinheiro - se por dinheiro entendermos o que Marx entendia -, que é o fato deles terem um preço, que a propósito não é uma taxa de juros, como ocorre quando o dinheiro passa a mediar-se a si mesmo como capital-portador-dejuros. Como o dinheiro não pode ter ele mesmo um preço, os derivativos parecem escapar desta categorização advogada por Bryan e Rafferty (2007). E, assim sendo, aqui nos parece mais adequado, levando em conta também os argumento já apresentados em seções anteriores, tratar os derivativos como mercadoria, ou melhor, como mercadoria-capital, capital que se fez ele mesmo mercadoria (o que não se confunde como o capital-mercadoria), o que nos levaria ao nosso ponto precedente de apreender o capital fictício como mercadoria-capital. Desse modo, seria mais apropriado tratálos como uma forma moderna de capital fictício, bem longe da realidade de Marx no século XIX, sendo a forma mercadoria o predicado que agora encarna algo do movimento do infinito hegeliano, tornando-se assim um predicado mais próximo do seu verdadeiro sujeito.

Neste caso, a teoria neoclássica, mesmo ao hipostasiar a aparência do mercado de derivativos, já revela algo da ordem da essência. Para esta corrente o problema central é precificar o contrato. Ora, o dinheiro não tem preço; quem o tem é a mercadoria. O que nos afasta da tese de Bryan e Rafferty (2007) - apesar dos seus inúmeros e interessantes insights -, pois eles tomam justamente os derivativos por dinheiro. Nosso ponto aqui é que a teoria convencional das finanças acerta ao tomar um contrato por uma mercadoria, ainda que lhe falte apreendê-la como uma mercadoria-capital. Se Bryan e Rafferty estivessem certos, se o derivativo fosse um novo tipo de dinheiro, o preço e os ganhos advindos dele seriam tomados em sua aparência como juros, assim como ocorre com o capital-portador-de-juros. Estes autores fixam-se demasiadamente no aspecto monetário dos contratos de derivativos, quando a sua essência nos aponta em verdade para sua 
forma mercadoria peculiar. É, pois, a precificação que denuncia a essência subjacente.

Com este argumento, fecharíamos logicamente nossa exposição, que partiu da nova determinação do dinheiro enquanto dinheiro inconversível para daí derivar a necessidade da posição de um novo tipo de capital fíctício próprio a ele, uma mercadoria-capital moderna e emergente no pós-1971 que se apresenta sob a forma dos derivativos financeiros.

Tratados como instrumentos de gerenciamento de risco, os derivativos, como os contratos sobre o dólar, podem lidar com o dinheiro como seu objeto. Lembrando o que nos diz Paulani (1991) sobre o capital financeiro ser essencialmente mercadoriadinheiro, dinheiro que é mediado e mediador ao mesmo tempo, onde a mediação atingiu todas as partes, inclusive a si mesma, agora vemos que se o derivativo é uma mercadoria, e sendo que ele pode se referir ao dinheiro, chegaríamos ao caso em que a mercadoria medeia o dinheiro (como ocorre nos forwards, futuros, swaps e opções sobre o dólar), mas que agora - após refeito todo o percurso da mercadoria ao capital e do capital de volta à mercadoria - se apresenta imbuída da riqueza de todo o movimento. Ela é, portanto, mercadoria-capital, assim como o absoluto refaz o percurso do imediato ao espírito e do espírito ao imediato.

Continuemos. Ainda há algo além disto.

O moderno desenvolvimento do capital fictício ensejou uma nova concepção de risco, historicamente específica (LiPuma e Lee 2005), que é a base da produção e da precificação dos derivativos. Estes instrumentos, por sua vez, unificam e objetivam vários tipos de risco, e contribuem assim efetivamente para a invenção de uma noção abstrata e historicamente determinada de risco, que detém um caráter social e semiótico específicos da época em que vivemos. Isto é, o tratamento do risco por meio de modelos estocásticos de precificação, que aparece como algo técnico, revela-se como algo que possui raízes sociais objetivas. Os modelos de equações diferenciais hipostasiam a aparência desta relação social como um caso de gerenciamento de risco (idem, p.413). Contudo, neste processo de criação de um sistema de derivativos, os riscos específicos, ao mesmo tempo em que se mantêm em sua particularidade, 
criam objetivamente um risco abstrato, um risco enquanto abstração real em meio às transações financeiras: "the financial derivative must presuppose the existence of abstract risk in the act and instrument of mitigating an amalgamation of concrete and specific risks.[...] The plurality of incommensurable types of risk is reduced to a singularity: risk in the abstract. The various concrete and situationally specific types of risk ... are abstracted into a single, homogeneous whole so that the financial community may price it" (idem, p.414 - ênfases nossas).

Neste processo de abstração real do risco, os objetos - os derivativos financeiros assumem um aspecto de objetos autônomos e independentes das relações sociais que os constituem, sendo que sua sociabilidade fica encoberta por seu preço. Dinâmica esta que se assemelha em muito com aquela vivida pela mercadoria, onde uma universalidade reduz todas as particularidades à forma preço. Os derivativos, assim como as mercadorias, também são objetos contraditórios, unidades de oposição entre universal e particular, e entre essência e aparência.

Vemos, portanto, que os derivativos somente podem ser precificados se houver um processo pressuposto de abstração real dos riscos específicos em um risco abstrato - assim como a mercadoria só tem preço porque a sociabilidade do mercado reduziu as diversas concretudes a uma abstração real. Assim, a objetivação do risco envolve dois momentos centrais: o descolamento em relação ao que os originou e a unificação das especificidades em uma medida abstrata. Sob a categoria de "risco" reduzem-se várias dimensões qualitativas a um quantum determinado, que somente se diferencia quantitativamente. $\mathrm{O}$ risco é, portanto, a medida do capital fictício.

A estrutura de mercadoria do derivativo fica assim entendida: o derivativo é, por um lado, valor-de-uso para os agentes que dele necessitam para se proteger das oscilações dos ativos e é, por outro lado, um valor-de-troca, uma abstração real, que serve à especulação (LiPuma e Lee 2005, p.417). Aqui a unidade de contrários se dá entre algo que serve à proteção em face de riscos concretos e específicos, e como algo abstrato que serve à especulação, ao desejo de se querer fazer dinheiro a partir de dinheiro na esfera da circulação. E, como decorrência disto, um pólo (o do valor-de-uso) acaba por servir de proteção ao que o outro pólo (o do valor-de-troca) realiza: hedging e especulação são dois momentos excludentes e inseparáveis do mesmo objeto. Assim 
sendo, o derivativo somente se constitui nesse negar-se e conservar-se dos seus momentos, mas para o qual o aspecto abstrato tem a tendência de autonomizar-se em relação ao seu suporte concreto.

Portanto, ao mesmo tempo em que se luta contra riscos específicos, acaba-se justamente por criar um risco abstrato, capaz de ser precificado: "risk has become a very peculiar and particular sociological object: to mitigate specific and concrete risks through the derivative, risk must be abstracted and monetized" (idem, p.417). Quando não há derivativos financeiros, não há risco abstrato. Em uma economia em que eles não operam como instrumentos de hedge, assim como era o mundo pré-1971, os riscos sempre apareciam como riscos concretos, imediatamente específicos e tratados com ações específicas. Na era pós-1971, o sistema pressupõe o próprio risco que cria. Ou seja, é um sistema de gerenciamento de risco que produz suas próprias pressuposições; seu resultado é sua pré-condição de existência. Cada derivativo financeiro é particularmente qualitativo na sua tentativa de capturar um conjunto determinado de riscos identificados e de riscos sistêmicos, e ao mesmo tempo produz o risco abstrato que medeia as inter-conexões dos ativos. Se para as mercadorias o trabalho abstrato, que elas mesmas produzem, lhes serve de medida e de mediação, para os derivativos o risco abstrato, que eles mesmos produzem, lhes serve de medida e mediação.

Lembremos, com Fausto (1997, p.137-171), que, para a dialética, não é sobre a constituição de uma totalidade que repousa o peso da fundação. A operação determinante é a redução, do nível concreto ao nível abstrato (e que continua com a posição do abstrato no concreto). A operação fundante (objetiva) não é a constituição de uma estrutura global a partir de elementos dispersos ou de relações simples dadas na aparência, mas sim a passagem do concreto da aparência ao abstrato-concreto da essência.

Nos mercados globais e líquidos destes “instrumentos”, não é a forma mercadoria nem a forma dinheiro que mediam as relações, mas o risco: "within the culture of financial circulation, risk itself will mediate social relations in place of other forms of social relation" (LiPuma e Lee 2005, p.418 - ênfases nossas). E, mais do que isso: nesta mesma dinâmica em que o risco é constituinte das relações e dos objetos, ele se 
expressará como algo contingente e ocasional. Risco abstrato este cuja unidade de medida é o tempo, e para o qual o sistema tendencialmente caminhará na direção de reduzi-lo. A redução do tempo é a redução do risco. Com isso, as transações revelam sua essencialidade curto-prazista. Ou seja, o tempo é tanto a fonte quanto a medida quantitativa do risco (idem, p.421).

O que fez do período pós-1971 uma época única é a objetivação e a abstração do risco como forças sociais mediadoras de relações de produção. E, por esta razão, o risco aparece de maneira reificada e, consequentemente, passível de ser apreendido matematicamente (idem, p.422). A posição objetiva do risco como mediador social serve à autonomização da circulação em face à produção.

Por fim, acrescentamos: os derivativos são "instrumentos", onde as aspas são propositais, pois indicam que aí opera uma negação. Se em sua superficialidade eles são instrumentos contra riscos particulares e concretos, eles mesmos produzem o risco abstrato. Se negam ao se afirmarem. E se mantêm nesta conservação de seus dois momentos. Sua operação evidencia que, se aparecem como instrumentos, em sua essência são produtores daquilo que pressupõe.

\subsubsection{Derivativos Financeiros como Capital Abstrato ou a Mercadoria como Capital Absoluto}

Não obstante, há algo mais profundo neste novo mercado que ainda não analisamos. Os derivativos, acima de tudo, estabelecem relações de precificação que conectam o futuro ao presente e vários lugares geográficos entre si. Este é o papel dos futuros, forwards e opções. Mas há também os swaps, que estabelecem relações de precificação que prometem uma conversão entre distintas formas de ativos e de índices: "Swaps are limited only by the imagination of financial engineers and the desire of corporate treasurers and fund managers for exotic structures" (Hull 2006, p.175). E, como já vimos acima, os derivativos não exigem a posse efetiva do ativo subjacente, mas requerem somente a exposição a um particular e indexável risco associado a ele. Esta separação entre o derivativo e o ativo em questão é crucial para sua liquidez e para sua fácil transferência. 
Assim sendo, vemos que os derivativos têm essas duas dimensões: abstraem das especificidades temporais e geográficas, e abstraem das especificidades dos ativos que representam. Sendo que esta abstração é uma abstração real, operada pelo próprio mercado e que aparece sob a forma do preço de contrato ${ }^{152}$. Os derivativos assumem os atributos de uma vastidão de diferentes tipos de ativos e os colocam juntos em um único produto - o que somente ocorre porque eles estão separados dos seus representados, ainda que deles tenham sido derivados. Ou seja, um derivativo é uma compilação de atributos de várias outras formas de títulos e índices, cuja melhor forma de expressão são os contratos de swap. Dessa maneira, o derivativo é algo com duplo caráter: é um contrato em específico, mas que ao mesmo tempo abstrai das especificidades de vários ativos e índices. Os swaps unificam ilimitadamente múltiplas características de ativos subjacentes. As combinações são infinitas. E, seguindo as palavras de Hegel: a abstração é uma potência que permite a passagem do particular ao universal, seja esta passagem realizada pelo intelecto ou pelas práticas cotidianas.

Cada derivativo é um contrato de conversão de uma forma de capital a outra, seja ele um simples contrato futuro sobre uma mercadoria ou uma conversão complexa de um particular índice monetário a um outro particular índice de ações. Quando todos estes produtos são unificados, eles formam uma rede complexa de conversões, um sistema de derivativos, no qual qualquer parte de um capital, em qualquer tempo e lugar, pode ser mensurado continuamente contra qualquer outra parte de um outro capital. Tais conversões se assentam sobre a comparação infinita entre as taxas de retorno de cada ativo através do tempo e do espaço (Bryan e Rafferty 2007; Lysandrou 2005), operando uma equalização geral de todos os índices de retorno.

\section{A generalização e a continuidade destas conversões operadas pelos derivativos acaba por unificar abstratamente todos os predicados do capital. Se todas a}

\footnotetext{
${ }^{152}$ Isto nos faz lembrar as palavras de Marx quando explicando a formação do preço das mercadorias a partir de uma abstração real dos trabalhos concretos: "essa redução sucede constantemente. [...] são fixadas por um processo social que se desenrola sem deles terem consciência os produtores, parecendolhes, por isso, estabelecidas pelo costume" (Marx 2002, p.66). "This average appears as an external abstraction if it is calculated out as the average figure of an epoch [...]; but it is very real if it is at the same time recognized as the driving force and the moving principle [... . This reality is not merely of theoretical importance: it forms the basis of mercantile speculation" (Marx 1973, p.137). "On paper, in the head, this metamorphosis proceeds by means of mere abstraction; but in the real exchange process a real mediation is required" (Marx 1973, p.142).
} 
diferentes formas de ativos e índices são mensurados de maneira contínua, o mercado de derivativos produz e expressa uma nova abstração do capital: o capital abstrato sui generis, capital abstraído objetivamente de maneira inédita ${ }^{153}$. O mercado de derivativos, ao generalizar-se se torna preponderante, realiza uma homogeneização de todos os ativos e índices possíveis, sejam eles dólares, euros, títulos de dívida, ações, índices de desempenho etc. Ou seja, põe objetivamente, através do "gerenciamento de risco", uma abstração que antes era somente subjetiva (que só fazia parte do discurso e da teoria).

Portanto, a tese deste item resume-se assim: os derivativos operam uma redução, uma abstração real, das várias especificidades das inúmeras formas de manifestação do capital. E, ao realizarem esta abstração, os derivativos mostram a força que tem o capital como universalidade, como abstração, como movimento. Esses contratos abstraem das especificidades dos "capitais" e as apresentam sob a forma sintética de um preço, preço este que é a abstração dos diversos capitais, e que é, por assim dizer, um capital abstrato.

Todos os predicados do capital são, assim, reduzidos à forma mercadoria, a qual recebe um preço. O capital, após ter percorrido o desenvolvimento de seus predicados e o seu próprio desenvolver-se, retorna agora ao seu predicado lógico inicial. Mas retorna carregando em seu interior todos seus desdobramentos, os quais ficam reduzidos a uma única abstração real, o preço de um derivativo. Para a teoria neoclássica, o desafio reside em precificar o contrato, para a teoria pós-keynesiana o desafio reside em mostrar que o que se toma por hedging é em verdade especulação e, para os marxistas, o desafio jaz em dizer dialeticamente o que é o derivativo, qual a sua essência. Aqui tentamos mostrar que os derivativos são essencialmente uma força universalizadora, que se efetivam como mercadorias sui generis - universalização esta que somente

\footnotetext{
153 "If all different forms of assets are being measured against each other on an on-going basis, derivatives markets create (express) a form of capital that we have hitherto thought of as only an abstraction (an 'essence' - a sort of DNA of capital - that all particular capitals share in common). By providing a process of capital commensuration, there is an on-going measure of all capital, in all forms, at all locations and across time" (Bryan e Rafferty 2007, p.142). Mas vale ressaltar que para estes autores os derivativos se aproximam da categoria de dinheiro, enquanto que para nós, como procuramos mostrar ao longo deste capítulo, os derivativos são uma mercadoria, mercadoria-capital, que tem um preço.
} 
poderia ter lugar após uma revolução digital e micro-eletrônica, em face à complexidade dos cálculos que tal abstração exige ${ }^{154}$.

O capital que se dirige aos derivativos, que estão livres das restrições imediatas impostas pela produção, é um capital auto-reflexivo, que se alimenta de seu próprio crescimento e, portanto, torna-se forma autônoma.

Em Hegel, o absoluto é o processo de recuperação/rememoração/internalização [Errinnerung] das figuras e do trajeto do espírito, para o qual a somatória das inúmeras inadequações entre sujeito e objeto foram se acumulando e que então tornam-se objeto pleno e transparente para a consciência. Em Marx, como vemos, o absoluto também seria um processo de rememoração e de internalização dos predicados do capital, mas que ao contrário de colocá-los transparentemente como objetos para a consciência, faz exatamente o contrário: vela toda a sua gênese lógica a aparece como forma fetichizada $^{155}$.

\footnotetext{
${ }^{154}$ Dessa forma, alguns desenvolvimentos substantivos tiveram que ocorrer para que essa abstração do capital fosse possível. Já mencionamos a revolução digital e micro-eletrônica. Caberia também enfatizar o crescente poder dos acionistas sobre a administração das empresas, a crescente importância dos mecanismos privados de alocação de recursos em relação aos controles estatais e a crescente mobilidade dos movimentos internacionais de capitais (Chesnais 2005 e 2002; Lysandrou 2005, p.787).

${ }^{155}$ Com a formação da taxa média global de lucro e sua implicação sobre os preços de produção, que patenteiam a tensão entre particular (mercadoria) e universal (capital global), o "capital se torna consciente de si mesmo como uma força social, em que cada capitalista participa proporcionalmente à sua parcela no capital global da sociedade" (Marx 1984a, p.150).

Nossa idéia aqui de absoluto em Marx está no capital fictício, mercadoria-capital, capital que retornou como capital ao seu predico inicial. Müller (2007), que segue Paulani (1991), põe a questão do fetiche para o capital-portador-de-juros: "Eis então que estamos diante do equivalente à idéia absoluta de Hegel; mas com uma diferença crucial: ela é o resultado do fetiche, não da auto-apreensão consciente do espírito" (p.128).
} 


\section{Referências $^{156}$}

AGLIETTA, Michel (1999) Les Transformations du Capitalisme Contemporain. In: Bernard Chavance, Éric Magnin, Ramine Motamed-Nejad, Jacques Sapir (dir.), Capitalisme et Socialisme en Perspective. Évolution et Transformation des Systèmes Économiques. Paris: La Découverte. Disponível em: http://lodel.ehess.fr/cemi/docannexe.php?id=1148

ALTHUSSER, Louis (1975/1979) Ler O Capital. Rio de Janeiro: Zahar (Edição em dois volumes).

ARNON, A. (1984a) Marx's Theory of Money: The Formative Years. History of Political Economy, Vol. 16, p.555-575.

ARTHUR, C. J. (2005) Value and Money. In: Moseley (2005) (org.) Marx's Theory of Money: Modern Appraisals. Palgrave Macmillan.

ARNON, A. (1984b) The Transformation in Thomas Tooke's Monetary Theory Reconsidered. History of Political Economy, Vol. 16, p.311-326.

BARGER, Harold (1935) Neutral Money and the Trade Cycle. Economica, New Series, Vol. 2, $\mathrm{n}^{\circ} 8$.

BELLOFIORE, Riccardo (2005) The Monetary Aspect of the Capitalist Process in the Marxian system: An Investigation from the Point of View of the Theory of the Monetary Circuit. In: Moseley (2005) (org.) Marx's Theory of Money: Modern Appraisals. Palgrave Macmillan.

BELlUZZO, L. M. Gonzaga (1980) Valor e Capitalismo: Um Ensaio sobre a Economia Política. Campinas: IE-Unicamp (1998)

BENTON, Ted (1984) The Rise and Fall of Structural Marxism: Althusser and his Influence. London: Macmillan

BERTOCCO, Giancarlo. (2007) Some Observations about the Loanable Funds Theory. Università degli Studi dell'Insubria. Working Paper. Disponível em: http://econpapers.repec.org/paper/insquaeco/qf0705.htm

BLAUG, Mark (1995a) Introduction. In: Blaug, Mark (1995) The Quantity Theory of Money: From Locke to Keynes and Friedman. Edward Elgar.

(1995b) Why is the Quantity Theory of Money the Oldest Surviving Theory in Economics?. In: Blaug, Mark (1995) The Quantity Theory of Money: From Locke to Keynes and Friedman. Edward Elgar.

\footnotetext{
${ }^{156}$ Quando existem duas datas, a primeira indica o ano de publicação da última edição da obra original, e a segunda indica o ano de tiragem que utilizamos para fazer as citações.
} 
BORGES NETO, J. M. (2002) Duplo Caráter do Trabalho, Valor e Economia Capitalista. São Paulo: IPE/USP (Tese de Doutorado)

BRANDOM, Robert (2002) Tales of the Mighty Dead: Historical Essays in the Metaphysics of Intentionality. Harvard University Press.

BRUNHOFF, Suzanne de (1975) La Oferta de Moneda : Crítica de un Concepto. Buenos Aires: Tiempo Contemporaneo (1978a) A Moeda em Marx. São Paulo: Paz e Terra. (1978b) A Política Monetária. São Paulo: Paz e Terra. (1982) Questioning Monetarism. Cambridge Journal of Economics, Vol. 6. (2005) A Instabilidade Monetária Internacional. In: Chesnais, F. (org) $A$ Finança Mundializada. São Paulo: Boitempo.

(2005b) Marx's Contribution to the Search for a Theory of Money. In: Moseley (2005) (org.) Marx's Theory of Money: Modern Appraisals. Palgrave Macmillan.

BRYAN, Dick e RAFFERTY, Michael (2007) Financial Derivatives and the Theory of Money. Economy and Society, Vol. 36 n 1, p.134-158.

CAMPBELL, Martha (2005) Marx's Explanation of Money's Functions: Overturning the Quantity Theory. In: Moseley (2005) (org.) Marx's Theory of Money: Modern Appraisals. Palgrave Macmillan.

CARCHEDI, Guglielmo (1991) Frontiers of Political Economy. New York: Verso

CARCHEDI, G. e deHANN, W. (1996) The Transformation Procedure: A NonEquilibrium Approach. In: Freeman e Carchedi (1996) (orgs.). Marx and Non-Equilibrium Economics. Cheltenham: Edward Elgar.

CARVALHO, F. Cardim de (1986) A Teoria Monetária de Marx: uma Interpretação Pós-Keynesiana. Revista de Economia Política, Vol 6 n4.

(2000) The Changing Role and Strategies of the IMF and the Perspectives for the Emerging Countries. Revista de Economia Política, vol. 20, nº 1.

(2004) Bretton Woods aos 60 Anos. Novos Estudos CEBRAP, $\mathrm{n}^{\circ} 70, \mathrm{p} .51$ 63.

CASSEL, Gustav (1918) Abnormal Deviation in International Exchanges. The Economic Journal, Vol. 28, pp. 413-415.

CHESNAIS, François (2002) A Teoria do Regime de Acumulação Financeirizado: Conteúdo, Alcance e Interrogações. Economia e Sociedade, Vol.11 nº1. 
(2005) A Finança Mundializada. São Paulo: Boitempo.

DERRIDA, Jacques (1991) O Poço e a Pirâmide. In: Margens da Filosofia. São Paulo: Papirus.

DEVINE, James (2000) The Rise and Fall of Stagflation: Preliminary Results. Review of Radical Political Economics, Vol. 3 nº3.

DUMENIL, G. (1980) De La Valeur aux Prix de Production: Une Réinterprétation de la Transformation. Paris : Economica.

(1983) Beyond the Transformation Riddle: A Labor Theory of Value. Science and Society, pp.427-450.

(1984) The So-Called Transformation Problem Revisited: A Brief Comment. Journal of Economic Theory, Vol. 33.

EICHENGREEN, Barry (1996/2000) A Globalização do Capital: Uma História do Sistema Monetário Internacional. São Paulo: Editora 34.

EICHENGREEN, B. e HAUSMANN, R. (2005) Other People's Money: Debt Denomination and Financial Instability in Emerging Market Economies. Chicago: University of Chicago Press. (Ed.)

ELSTER, Jon (1985) Making Sense of Marx. Cambridge: Cambridge University Press. (1989) Marxismo, Funcionalismo e Teoria dos Jogos. Lua Nova: Vol 17.

FAUSTO, Ruy (1987a) Marx: Lógica e Política - Tomo I. São Paulo: Brasiliense.

(1987b) Marx: Lógica e Política - Tomo II. São Paulo: Brasiliense.

(1997) Dialética Marxista, Dialética Hegeliana: A Produção Capitalista como Circulação Simples. São Paulo: Paz e Terra

FINE, Ben e LAPAVITSAS, Costas (2000) Markets and Money in Social Theory: What Role for Economics? Economy and Society, Vol. 29 nº3, p.357-382

FINE, B., C. LAPAVITSAS, e A. SAAD-FILHO (2004) Transforming the Transformation Problem: Why the New Interpretation is a Wrong Turning. Review of Radical Political Economics, Vol. 36 n $^{\circ}$, p. 3-19.

FISHER, Irving (1911/1922) The Purchasing Power of Money: Its Determination and Relation to Credit, Interest, and Crises. New York: The Macmillan Company. Disponível em: http://www.econlib.org/library/YPDBooks/Fisher/fshPPM.html

FOLEY, D. K. (1982) The Value of Money, the Value of Labor Power and the Marxian Transformation Problem. Review of Radical Political Economics, Vol. 14 $\mathrm{n}^{\circ} 2$. 
(1986) Understanding Capital: Marx's Economic Theory. Cambridge: Harvard University Press.

(1997) Review of Marx and Non-Equilibrium Economics. Eastern Economic Journal. Vol. 23, nº4.

(2000) Recent Developments in the Labor Theory of Value. Review of Radical Political Economics, Vol. $32 \mathrm{n}^{\circ} 1$.

(2005) Marx's Theory of Money in Historical Perspective. In: Moseley (2005) (org.) Marx's Theory of Money: Modern Appraisals. Palgrave Macmillan.

FONTANA, Giuseppe (2003) Post Keynesian Approaches to Endogenous Money: A Time Framework Explanation. Review of Political Economy, Vol. 15 n³, p.291-314.

FREEMAN, A. e CARCHEDI, G. (1996) (orgs.) Marx and Non-Equilibrium Economics. Cheltenham: Edward Elgar.

FRIEDMAN, Milton (1968) Dollars and Deficits: Inflation, Monetary Policy and the Balance of Payments. Prentice-Hall

GERMER, Claus (2005) The Commodity Nature of Money in Marx's Theory. In: Moseley (2005) (org.) Marx's Theory of Money: Modern Appraisals. Palgrave Macmillan.

GONTIJO, C. (2005) A Transformação de Valores em Preços Segundo o Sistema Temporal Único: Uma Apreciação Crítica. ANPEC: Anais do $33^{\circ}$ Encontro Nacional.

GREEN, R. (1982) Money, Output and Inflation in Classical Economics. Contributions to Political Economy, Vol. 1, p.59-85.

GRESPAN, Jorge L. da S. (1999) O Negativo do Capital. São Paulo: Hucitech , FAPESP

(2002) A Dialética do Avesso. Revista Crítica Marxista, $\mathrm{n}^{\circ} 14$.

GUIMARÃES, Alberto P. (1984) A Inflação (Brasileira) Segundo Marx. Revista de Economia Política, Vol. 4 nº 4.

HARVEY, David (2007) The Limits to Capital. New York: Verso.

HEGEL, G. W. F. (1840/1988) Introduction to the Philosophy of History. Indianapolis: Hackett.

(1830/1995) Enciclopédia das Ciências Filosóficas em Compêndio: Tomo I - A Ciência da Lógica. São Paulo: Edições Loyola. 
(1830) Encyclopaedia of the Philosophical Sciences in Outline. Edição de 1830. Disponível em: http://www.marxists.org/reference/archive/hegel/ works/

(1817) Encyclopaedia of the Philosophical Sciences in Outline. Edição de 1817. Disponível em: http://www.marxists.org/reference/archive/hegel/ works/

(1816) Science of Logic ("A Grande Lógica”) Disponível em: http://www.marxists.org/reference/archive/hegel/works/hl/hl000.htm

(1807/2002) Fenomenologia do Espírito. São Paulo: Vozes.

HICKS, J. R. (1967) Critical Essays in Monetary Theory. London: Clarendon Press.

HILFERDING, Rudolf (1910/1981) Finance Capital: A Study of the Latest Phase of Capitalist Development. London; Boston : Routledge \& Kegan Paul.

HULL, John C. (2006) Option, Futures and Other Derivatives. Sixth Edition. Prentice Hall.

HYPPOLITE, Jean (1947/1999) Gênese e Estrutura da Fenomenologia do Espírito de Hegel. São Paulo: Discurso Editorial

ITOH, Makoto (2005) The New Interpretation and the Value of Money. In: Moseley (2005) (org.) Marx's Theory of Money: Modern Appraisals. Palgrave Macmillan.

ITOH, Makoto e Lapavitsas, Costas (1999) Political Economy of Money and Finance. London: MacMillan.

JINNAI, Yoshiaki (2005) Towards a Dialectical Interpretation of the Contemporary Mode of Capitalist Accounting. Critical Perspectives on Accounting, Vol. 16 p.95-113.

KLIMAN, A. (2001) Simultaneous Valuation Vs. The Exploitation Theory of Value. Capital and Class, Vol. 73.

KLIMAN, A. e McGLONE, T. (1999) A Temporal Single-System Interpretation of Marx's Value Theory. Review of Political Economy, Vol. 11, ${ }^{\circ} 1$.

KNAPP, Georg Friedrich (1924) The State Theory of Money. London: Macmillan. Disponível em: http://socserv.mcmaster.ca/econ/ugcm/3113/knapp/ StateTheoryMoney.pdf

KRISTJANSON-GURAL, David (2008) Money Is Time: The Monetary Expression of Value in Marx's Theory of Value. Rethinking Marxism, Vol. $20 \mathrm{n}^{\circ} 2$, p.257272. 
LAPAVITSAS, Costas (1994) The Banking School and the Monetary Thought of Marx. Cambridge Journal of Economics, Vol. 18, p.447-461.

(2000) Money and the Analysis of Capitalism: The Significance of Commodity Money. Review of Radical Political Economics, Vol. 32 nº, p. 631-656.

(2005) The Social Relations of Money as Universal Equivalent. Economy and Society, Vol.34 n⿳3.

(2005b) The Universal Equivalent as Monopolist of the Ability to Buy. In: Moseley (2005) (org.) Marx's Theory of Money: Modern Appraisals. Palgrave Macmillan.

LAVOIE, M. (1984) The Endogenous Flow of Credit and the Post Keynesian Theory of Money. Journal of Economic Issues, Vol.18 n³.

LEBRUN, Gerard (2006) A Paciência do Conceito: Ensaio sobre o Discurso Hegeliano. São Paulo: Editora Unesp.

LIKITKIJSOMBOON, Pichit (2005) Marx's Anti-Quantity Theory of Money: A Critical Evaluation. In: Moseley (2005) (org.) Marx's Theory of Money: Modern Appraisals. Palgrave Macmillan.

LIPUMA, E. e LEE, B. (2005) Financial Derivatives and the Rise of Circulation. Economy and Society, Vol. 34 n³, p.407-427.

LYSANDROU, P. (2005) Globalisation as Commodification. Cambridge Journal of Economics, Vol. 29, p.769-797.

MARX, Karl (1857/1982) Para a Crítica da Economia Política. São Paulo: Abril Cultural. Coleção Os Economistas.

(1890/2002) O Capital (Livro I) - O Processo de Produção do Capital. Rio de Janeiro: Civilização Brasileira.

(1893/2000) O Capital (Livro II) - O Processo de Circulação do Capital. Rio de Janeiro: Civilização Brasileira.

(1894/1984a) O Capital (Livro III - Volume 1) - O Processo Global Produção Capitalista. São Paulo: Abril Cultural. Coleção Os Economistas.

(1894/1984b) O Capital (Livro III - Volume 2) - O Processo Global Produção Capitalista. São Paulo: Abril Cultural. Coleção Os Economistas.

(1863) Theories of Surplus Value. Disponível em: http://marxists.org/archive/marx/works/1863/theories-surplus-

value/index.htm 
(1939/1973) Grundrisse: Foundations of the Critique of Political Economy. New York: Vintage Books. Também disponível on-line em: http://www.marxists.org/archive/marx/works/1857/grundrisse/index.htm

MENEZES, Paulo (1992) Para Ler a Fenomenologia do Espírito. São Paulo: Loyola

MILL, John Stuart (1871/1983) Princípios de Economia Política. Volume II. São Paulo: Abril Cultural. Coleção Os Economistas.

MINSKY, Hyman (1982) Inflation, Recession and Economic Policy. Prentice Hall, Harvester Wheatsheaf.

MOLLO, M. L. R. (1989) Monnaie, Valeur et Capital Fictif. Thèse de Doctorat. Paris: Université de Paris X.

(1991) A Relação entre Moeda e Valor em Marx. Revista de Economia Política, Vol. $11 \mathrm{n}^{\circ} 2$.

(2004) Ortodoxia e Heterodoxia Monetárias: A Questão da Neutralidade da Moeda. Revista de Economia Política, Vol. 24 n³.

MOSELEY, Fred (2004) The "Monetary Expression of Labor" in the Case of NonCommodity Money. Working Paper. Disponível em: http://www.mtholyoke.edu/ fmoseley/Working_Papers_PDF/melt.pdf

(2005) Introduction. In: Moseley (2005) (org.) Marx's Theory of Money: Modern Appraisals. Palgrave Macmillan.

MÜLLER, Leonardo P. (2007) A Modernidade do Capital. Monografia de Graduação. São Paulo: FEA-USP.

NAPLES, M. (1996) Time, Money and Equilibrium: Methodology and the Labour Theory of the Profit Rate. In: Freeman e Carchedi (1996) (orgs.). Marx and Non-Equilibrium Economics. Cheltenham: Edward Elgar.

NELSON, Anitra (2005) Marx's Objection to Credit Theories of Money. In: Moseley (2005) (org.) Marx's Theory of Money: Modern Appraisals. Palgrave Macmillan.

OREIRO, José Luís (2001) Taxa de Juros, Preferência Pela Liquidez e Fundos de Empréstimo: Uma Análise Crítica das Tentativas de Demonstração da Equivalência entre as Teorias dos Fundos de Empréstimos e de Preferência pela Liquidez. Revista de Economia Política, Vol.21 n².

PAUlANI, Leda M. (1991) Do Conceito de Dinheiro e do Dinheiro como Conceito. São Paulo: IPE/USP (Tese de Doutorado). (1994) - Sobre Dinheiro e Valor - Uma Crítica às Posições de Brunhoff e Mollo. Revista de Economia Política, Vol.14 n³. 
(2005) Modernidade e Discurso Econômico. São Paulo: Boitempo.

PERELMAN, Michael (1990) The Phenomenology of Constant Capital and Fictitious Capital. Review of Radical Political Economics, Vol. 22, p.66-91.

PINEAULT, Eric (2001) Finance Capital and Institutional Foundations of Capitalist Finance: Theoretical Elements from Marx to Minsky. Working Paper. Disponível em: https://depot.erudit.org/retrieve/774/000267pp.pdf

PINKARD, Terry (1996) Hegel's Phenomenology: The Sociability of Reason. Cambridge: University Press.

PIPPIN, R. (1989) Hegel's Idealism: The Satisfaction of Self-Consciousness. Cambridge University Press.

POLANY, Karl (1944/2000) A Grande Transformação. Rio de Janeiro: Elsevier.

PRYKE, M. e ALLEN, J. (2000) Monetized Time-Space: Derivatives - Money's 'New Imaginary'. Economy and Society, Vol. 29 n², p. 264-284.

RAMOS-MARTINEZ, A. e RODRIGUEZ-HERRERA, A. (1996) The Transformation of Values Into Prices of Production: A Different Reading of Marx's Text. In: Freeman e Carchedi (1996) (orgs.). Marx and Non-Equilibrium Economics. Cheltenham: Edward Elgar.

REUTEN, Geert (2005) Money as Constituent of Value. In: Moseley (2005) (org.) Marx's Theory of Money: Modern Appraisals. Palgrave Macmillan.

RICARDO, David (1819/2005) The Works and Correspondence of David Ricardo, Vol. 5 - Speeches and Evidence, 1815-1823. In: The Works and Correspondence of David Ricardo, ed. Piero Sraffa with the Collaboration of M.H. Dobb. Indianapolis: Liberty Fund. Disponível em: http://oll.libertyfund.org/index.php?option=com_staticxt\& staticfile $=$ show.php?title $=159 \&$ Itemid $=99999999$

RODRIGUEZ-HERRERA, A. (1996) Money, The Postulates of Invariance and the Transformation of Marx Into Ricardo. In: Freeman e Carchedi (1996) (orgs.). Marx and Non-Equilibrium Economics. Cheltenham: Edward Elgar.

ROSDOLSKY, Roman (1968/2001) Gênese e Estrutura de O Capital de Karl Marx. Rio de Janeiro: Contraponto.

ROTMAN, Brian (1987) Signifying Nothing: The Semiotics of Zero, New York: St. Martin's Press.

RUBIN, Isaak Illich (1928/1987) A Teoria Marxista do Valor. São Paulo: Polis.

SAAD FILHO, Alfredo (1990) Contradições Mercantis no Processo de Acumulação do Capital: $O$ Exemplo da Inflação. Brasília: ECO/Unb (Tese de Mestrado). 
(1997) Re-reading both Hegel and Marx: The New Dialectics and the Method of Capital. Revista de Economia Política, Vol 17 n ${ }^{\circ}$.

(2002) The Value of Marx: Political Economy for Contemporary Capitalism. Londres: Routledge

SAFATLE, V. (2006) Linguagem e Negação: Sobre as Relações entre Ontologia e Pragmática em Hegel. DoisPontos, Vol.3 nº1, p.109-146. Disponível em: http://ojs.c3sl.ufpr.br/ojs2/index.php/doispontos/article/view/5163/3885

SANTOS, R. C. dos (1999) A Teoria do Capital de Turgot. Revista de Economia Política. Vol. 19, n³.

(2005) Alguns Mitos sobre a Riqueza das Nações. IPE-USP: Programa de Seminários Acadêmicos, p. 1-22. Mimeo.

SAROS, Daniel E. (2007) The Price-Form as a Fractional Reflection of the Aggregate Value of Commodities. Review of Radical Political Economics, Vol. 39, p. 407.

SCHUMPETER, J. A. (1955) History of Economic Analysis. New York: Oxford University Press.

SETON, F. (1957) The Transformation Problem. The Review of Economic Studies, n 24, pp.149-160.

SHILlER, R. (2003) The New Financial Order: Risk in the 21st Century. Princeton, NJ: Princeton University Press.

SOROMENHO, J. E. C. (1986) Uma Análise da Evolução do Conceito de Equilíbrio Monetário no Pensamento Sueco: Um Estudo em História do Pensamento Econômico. São Paulo: IPE-USP. Tese de Mestrado.

(1994) Estudo sobre as Origens da Crítica de Hayek ao Conceito de Equilíbrio. São Paulo: IPE-USP. Tese de Doutorado.

SOUZA, J. P. A. de (2007) A Teoria do Valor-Trabalho e o Problema da Transformação: Uma Análise com Foco no Sistema Único Temporal. São Paulo: IPE-USP. Dissertação de Mestrado. Disponível em: http://www.teses.usp.br/teses/disponiveis/12/12140/tde-04102007-105111/

TEIXEIRA, Rodrigo Alves (2007) A Produção Capitalista do Conhecimento e o Papel do Conhecimento na Produção Capitalista: Uma Análise a partir da Teoria Marxista do Valor. Anais do Congresso Nacional do ANPEC.

THORNTON, Henry (1802/1965) An Enquiry into the Nature and Effects of the Paper Credit of Great Britain. New York: A.M. Kelley.

TORRES FILHO, M. R. (2006) O Pensamento Monetário de Henry Thornton em 1802 e em 1810. IPE-USP: Dissertação de Mestrado. 
TRAUTWEIN, Hans-Michael (1996) Endogenous Money: Modern Difficulties with the Wicksellian Approach. The Canadian Journal of Economics / Revue canadienne d'Economique, Vol. 29, Special Issue: Part 1, pp. S228-S234.

TRIFFIN, Robert (1972) O Sistema Monetário Internacional. Rio de Janeiro: Editora Expressão e Cultura.

VROLIJK, C. (1997) Derivatives Effect on Monetary Policy Transmission'. IMF Monetary and Exchange Department. Working Paper, WP-97-121.

WICKSELL, Knut (1950) Lectures on Political Economy. London: Routledge. Edição em dois volumes.

(1965) Interest and Prices: A Study of the Causes Regulating the Value of Money. New York: Kelley.

WILLIAMS, Michael (2000) Why Marx Neither Has nor Needs a Commodity Theory of Money. Review of Political Economy, Vol.12 n 4 , p.435-451.

WOLFF, E.; CALLARI, A.; ROBERTS, B. (1982) Marx's (not Ricardo's) "Transformation Problem: A Radical Reconceptualization. History of Political Economy, Vol.14 n ${ }^{\circ}$.

(1984) A Marxian Alternative to the Traditional "Transformation Problem”. Review of Radical Political Economics, Vol. 16. 